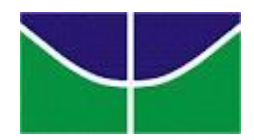

UNIVERSIDADE DE BRASÍLIA

FACULDADE DE EDUCAÇÃO

PROGRAMA DE PÓS-GRADUAÇÃO EM EDUCAÇÃO

ÁREA DE CONCENTRAÇÃO: POLÍTICASS PÚBLICAS E GESTÃO DA

EDUCAÇÃO BÁSICA

\author{
RAIMUNDO RAINERO XAVIER
}

A INSTITUIÇÃO DO PISO SALARIAL PROFISSIONAL NACIONAL (PSPN) POR MEIO DA LEI 11.738/2008 VALORIZA OS PROFESSORES DO MAGISTÉRIO DA EDUCAÇÃO BÁSICA?

Brasília - DF, outubro de 2015. 


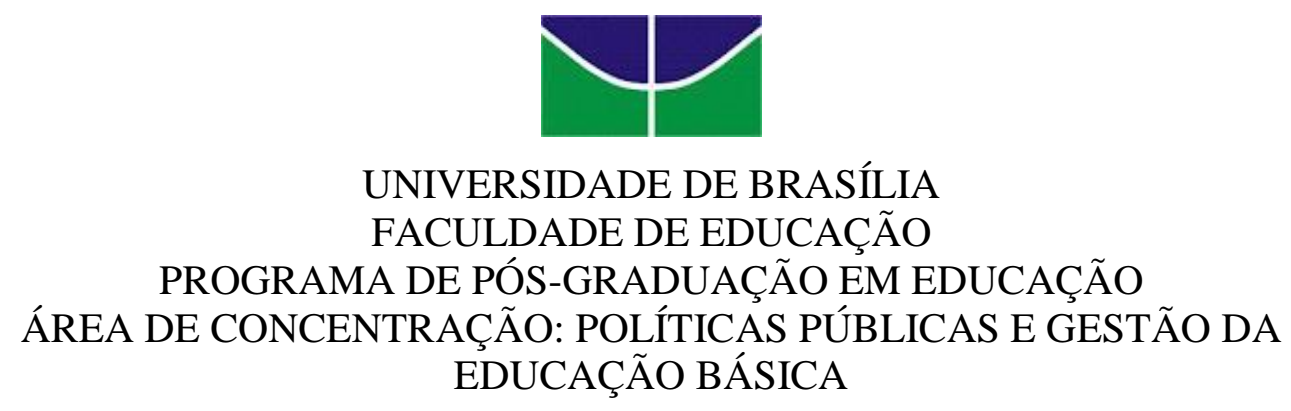

RAIMUNDO RAINERO XAVIER

A INSTITUIÇÃO DO PISO SALARIAL PROFISSIONAL NACIONAL (PSPN) POR MEIO DA LEI 11.738/2008 VALORIZA OS PROFESSORES DO MAGISTÉRIO DA EDUCAÇÃO BÁSICA?

Dissertação de Mestrado Profissional apresentada ao Programa de Pós-Graduação em Educação da Faculdade de Educação da Universidade de Brasília, vinculdada à linha de pesquisa Políticas Públicas e Gestão da Educação como exigência parcial para obtenção do título de Mestre em Educação.

Orientadora: Profa. Dra. Maria Abádia da Silva

Brasília - DF, outubro de 2015. 
$\mathrm{X} 3 \mathrm{i}$

Xavier, Raimundo Rainero

A instituição do Piso Salarial Profissional Nacional (PSPN) por meio da Lei 11.738/2008 valoriza os professores do magistério da educação básica? / Raimundo Rainero Xavier; orientadora Prof ${ }^{\mathrm{a}}$ Dra. Maria Abádia da Silva. - Brasília, 2015.

$172 \mathrm{p}$.

Dissertação (Mestrado - Mestrado Profissional em Educação) -Universidade de Brasília, 2015.

1. Educação básica. 2. Valorização de professores. 3. Piso Salarial Profissional Nacional. I. Silva, Maria Abádia da. II. Título 


\title{
A INSTITUIÇÃO DO PISO SALARIAL PROFISSIONAL NACIONAL (PSPN) POR MEIO DA LEI 11.738/2008 VALORIZA OS PROFESSORES DO MAGISTÉRIO DA EDUCAÇÃO BÁSICA?
}

\author{
Dissertação de Mestrado Profissional \\ apresentada ao Programa de Pós-Graduação \\ em Educação da Faculdade de Educação da \\ Universidade de Brasília, vinculdada à linha \\ de pesquisa Políticas Públicas e Gestão da \\ Educação como exigência parcial para \\ obtenção do título de Mestre em Educação.
}

Brasília - DF, 23 de outrubro de 2015.

\section{Comissão Examinadora}

Professora Dra. Maria Abádia da Silva

Orientadora - Faculdade de Educação/UnB

Professora Dra. Kátia Augusta Curado Pinheiro Cordeiro da Silva

Examinadora Interna - Faculdade de Educação/UnB

Professor Doutor Edson Marcelo Hungaro

Examinador Externo - Faculdade de Educação Física/UnB

Professor Doutor Erlando da Silva Rêses

Examinador Interno (Suplente) - Faculdade de Educação/UnB 


\section{AGRADECIMENTOS}

À professora Maria Abádia da Silva, meus agradecimentos pelo apoio, compreensão e competência com que me orientou e compartilhou suas experiências e conhecimentos no campo da educação, contribuindo para minha evolução acadêmica e humana.

Aos professores da Faculdade de Educação, com os quais tive a oportunidade de conviver e aprender, propiciando importantes momentos de discussões e relevantes leituras durante as disciplinas cursadas, que muito contribuíram para minha evolução acadêmcia.

Aos professores que compuseram a banca, Professora Kátia Augusta Curado Pinheiro Cordeiro da Silva (membro interno), Professor Edson Marcelo Hungaro (membro externo), Professor Erlando da Silva Rêses (membro interno - suplente), que muito contribuíram para o enriquecimento do meu trabalho acadêmico.

Ao grupo de colegas mestrandos e doutorandos com os quais tive a oportunidade de conviver e aprender coletivamente.

Aos gestores educacionais federais, municipais e dirigentes de entidade nacional e sindicais municipais de professores da educação básica, que muito colaboraram para a realização deste trabalho.

Aos gestores e técnicos da Divape/Sase/MEC pela colaboração, apoio, respeito e calor humano nos momentos mais difíceis de elaboração deste trabalho.

Aos meus queridos familiares: pais (in memoriam) que, na sua simplicidade e com carinho, souberam apontar-me o horizonte do conhecimento; irmãos, irmãs, filhas, genro, sobrinhos (as), cunhados (as) pela compreensão e respeito em momentos difíceis na construção deste trabalho. À minha esposa e amiga Tereza, pelo apoio, companheirismo incondicional e sintonia espiritual em todos os momentos de luta e alegria. À minha neta Clarissa, pela alegria e felicidade que trouxe à minha vida e com quem espero poder compartilhar minha história. 


\section{RESUMO}

O presente trabalho teve o objetivo de analisar a instituição do Piso Salarial Profissional Nacional (PSPN) como ação política implementada pelo Estado, por meio da sanção da Lei 11.738/2008, para explicitar a necessidade e relevância que se atribui à valorização econômica e financeira dos professores do magistério público da educação básica, ao mesmo tempo, desvelar como no âmbito da ordem capitalista vigente no país contribui para minimizar a potencialidade do trabalho docente como categoria fundante do ser humano. $\mathrm{O}$ eixo norteador foi a seguinte questão: a instituição do Piso Salarial Profissional Nacional por meio da Lei 11.738/2008 valoriza os professores da educação básica? Priorizou-se as categorias analítico-filosóficas ideologia e alienação do Método Histórico e Dialético (MHD), para apreender o sentido de valorização do trabalho docente na instituição do PSPN na visão dos gestores educacionais federais e municipais, e dirigentes de entidade nacional e sindicais municipais participantes da pesquisa empírica e, igualmente, nas ações realizadas pela Secretaria de Articulação com os Sistemas de Ensino (Sase) do Ministério da Educação (MEC). O trabalho de campo foi realizado por meio de entrevista semiestruturada com nove sujeitos. Os resultados do estudo mostraram que, por um lado, a instituição do PSPN é necessária para a implementação de um Sistema Nacional de Educação (SNE); o PSPN é necessário e relevante porque propicia melhores condições de vida aos professores e suas famílias; a instituição do PSPN valoriza o salário dos professores; mas, por outro lado, dentro do sistema capitalista em vigor no país, minimiza a potencialidade do trabalho docente e o professor como ser humano produtor do trabalho educativo nas escolas públicas. Sugere duas alternativas para o desenvolvimento da política de valorização dos professores da educação básica: (a) agregar outros elementos ao PSPN na implementação dos planos de carreira dos professores do magistério da educação básica e, assim, contribuir para legitimar a função do Estado no sentido de fortalecer a ordem capitalista vigente no país; (b) realizar um balanço crítico da política de valorização dos professores do magistério da educação básica vigente, na perspectiva de que seja adotado como eixo dessa política o trabalho docente enquanto emancipação humana dos professores, em substituição ao foco que é dado à valorização salarial dos professores no âmbito da ordem capitalista vigente do país.

Palavras-chave: Piso Salarial Profissional Nacional (PSPN). Valorização do trabalho docente. Ideologia. Alienação. Educação Básica Pública. 


\begin{abstract}
The following work aims to analyse tha institution of the Piso Salarial Profissional Nacional PSPN (the National Professional Minimum Wage) as a political action implemented by the State, by the sanctioning of Law 11.738/2008, to highlight the relevance attributed to the economic and financial valuing of public teachers in the area of basic education, and, at the same time, show how the importance given to this element in the scope of the reigning capitalistic order serves to hide the impoverishment of the potential of pedagogical work as a basic category for the human being. Following this line of reasoning, the guiding principle that was adopted was the question: Does the institution of the national professional minimum wage by Law 11.738/2008 promote the value of the teachers in basic education? In search of an answer, the author made use on the analytic phylosophical categories known as ideology and alienation in the Dialectical and Histotical Method to apprenhend the meaning of promoting the value of pedagogical work in the institution of the PSPN in the understanding of the federal and municipal educational administrators and directors of national entities and municipal unions that took part in the empirical research, as well as in the understanding of the actions carried out by the Office for the Articulation of Systems of Teaching (Secretaria de Articulação com os Sistemas de Ensino - Sase) of the Ministery of Education (MEC). The results of the study have shown that the creation of the PSPN increases the value on the salaries of teachers in basic education within the reigning capitalistic system in our country. However, it disempowers the job of teaching as a basic category for the human being and, in the same way, the teacher as the source of the educational work in the public schools. Therefore, the author concludes by presenting two alternative proposals for the development of a policy to promote the value of the teachers in basic education: (a) adding other elements to the PSPN for the implementation of the career plans of teachers in basic education, in order to legitimize the role of the State and, in this way, strengthen the reigning capitalistic order; and (b) conduct a critical analysis of the existing policy to promote the value of the teachers in basic aducation, with the aim of adopting, as the basis of this policy, the pedagogical work as a means of human emancipation for teachers, as opposed to the importance given to the increase of the wages of teachers in the scope of the reigning capitalistic order.
\end{abstract}

Keywords: Piso Salarial Profissional Nacional. Minimum Wage. Value of Pedagogical Work. Ideology. Alienation. Basic Education. 


\section{LISTA DE SIGLAS}

ADI Ação Direta de Inconstitucionalidade

ADCT Ato das Disposições Constitucionais Transitórias

ANC Assembléia Nacional Constituinte

ANDES Sindicato Nacional dos Docentes das Instituições de Ensino Superior

ASPAR Assessoria Parlamentar

AGU Advocacia Geral da União

BID Banco Interamericano de Desenvolvimento

BM Banco Mundial

CF Constituição Federal

CNE Conselho Nacional de Educação

CNTE Confederação Nacional dos Trabalhadores em Educação

CONEB Conferência Nacional de Educação Básica

CONAE Conferência Nacional de Educação

CN Congresso Nacional

CPB Confederação dos Professores do Brasil

CAC Conselho de Acompanhamento e Controle Social

CONSED Conselho dos Secretários Estaduais de Educação

CRUB Conselho de Reitores das Universidades Brasileiras

CEPAL Comissão Econômica para América Latina e Caribe

CONJUR Consultoria Jurídica

EC Emenda Constitucional

EM Exposição de Motivos

FUNDEF Fundo de Manutenção e Desenvolvimento do Ensino Fundamental e do Magistério

FUNDEB Fundo de Manutenção e Desenvolvimento da Educação Básica

e Valorização dos Profissionais da Educação

FASUBRA Federação dos Sindicatos e Trabalhadores em Educaçao das Universidades

Brasileiras

DF Distrito Federal

DIVAPE Diretoria de Valorização dos Profissionais da Educação

DOU Diário Oficial da União

FE Faculdade de Educação 
FUB Fundação Universidade de Brasília

GO Goiás

IDEB Índice de Desenvolvimento da Educação Básica

LDB Lei de Diretizes e Bases da Educação Nacional

MEC Ministério da Educação

MHD Método Histórico Dialético

MTE Ministério do Trabalho e Emprego

MDE Manutenção e Desenvolvimento do Ensino

MP Medida Provisória

ME Ministério Público

PCR Plano de Carreira e Remuneração

PL Projeto de Lei

PNE Plano Nacional de Educação

PPGE Programa de Pós-Graduação em Educação

PA Pará

PCCR Plano de Cargo, Carreira e Remuneração

PT Partido dos Trabalhadores

PM Portaria Ministerial

PIB Produto Interno Bruto

PAR Plano de Ações Articuladas

PSN Piso Salarial Nacional

SASE Secretaria de Articulação com os Sistemas de Ensino

SEMED Secretaria Municipal de Educação

SIMEC Sistema de Informações do Ministério da Educação

SF Senado Federal

SNE Sistema Nacional de Educação

STF Supremo Tribunal Federal

SEB Secretaria de Educação Básica

SECADI Secretaria de Educação Continuada, Alfabetização, Diversidade e Inclusão

TC Termo de Coopração

TCU Tribunal de Contas da União

UnB Universidade de Brasília

UBES União dos Estudantes Secundaristas

UNE União Nacional dos Estudantes 
UNDIME União Nacional dos Dirigentes Municipais de Educação

UFMG Universidade Federal de Minas Gerais

VAA Valor Aluno Ano 


\section{LISTA DE TABELAS, GRÁFICOS E QUADROS}

Tabela 01 - Vencimento e Hora Atividade dos professores das redes de educação básica nos estados

Tabela 02 - Vencimento e Hora Atividade dos professores das redes de educação básica nas capitais

Gráfico 01 - Pagamento do PSPN nos estados

Gráfico 02 - Pagamento do PSPN nas capitais

Gráfico 03 - Hora-atividade nos estados

Gráfico 04 - Hora-atividade nas capitais

Quadro 01: Gestores educacionais federais e municipais, dirigentes de entidade nacional e sindicais municipais entrevistados

Quadro 02 - Perfil dos gestores educacionais federais e municipais e dirigentes de entidade nacional e sindicais municipais de professores

Quadro 03 - Síntese da visão dos gestores e dirigentes sobre a implementação do Piso Salarial Profissional Nacional e planos de carreira em favor da valorização dos professores da educação básica

Quadro 04 - Síntese dos elementos que valorizam os professores do magistério da educação básica na visão dos gestores educacionais federais e municipais, dirigentes de entidade nacional e sindicais municipais de professores 


\section{SUMÁRIO}

INTRODUÇÃOO

CAPÍTULO 1 - A Lei 11.738/2008 como ferramenta de valorização dos profissionais da educação básica na lógica do capital

1.1 A inserção da Lei 11.738/2008 na política de valorização dos profissionais da educação básica: Estado democrático nos marcos da ordem capitalista vigente no país

1.2 A inserção da valorização dos profissionais da educação na Constituição Federal de 1988 e em legislação infraconstitucional

1.3 A Lei 11.738/2008: um instrumento da política de valorização dos profissionais da educação básica 48

1.4 A instituição do Piso Salarial Profissional Nacional (PSPN) como expressão política do Estado

CAPÍTULO 2 - A instituição da Lei 11.738/2008, valorização e plano de carreira sob a visão dos gestores educacionais federais e municipais e dirigentes de entidade nacional e sindicais municipais de professores da educação básica 62

2.1 Ideologia e alienação: o sentido da ação política do Estado em favor da valorização dos professores nos marcos da ordem capitalista vigente no país

2.2 Trabalho e trabalho docente: processos de desumanização

2.3 Visão dos gestores educacionais federais e municipais, e de dirigentes de entidade nacional e sindicais municipais de professores sobre a implementação da Lei 11.738/2008. 79

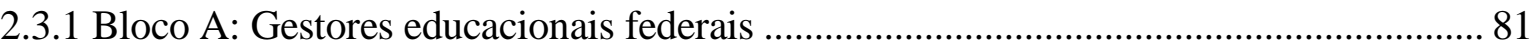

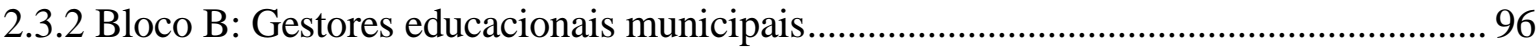

2.3.3 Bloco C: Dirigentes de entidade nacional e sindicais muncipais de professores .......... 107

CAPÍTULO 3 - A implantação da Lei 11.738/2008: conquista, avanços e limites......... 120

3.1 Avanços: outros elementos e formas de valorização sugeridos pelos gestores federais e municipais, dirigente de entidade nacional e sindicais municipais

3.1.1 Bloco A: Gestores educacionais federais

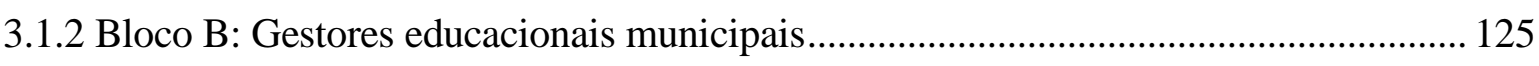

3.1.3 Bloco C: Dirigentes de entidade nacional e sindicais municipais de professores ........ 128

3.2 As perspectivas da Divape/Sase/MEC no encaminhamento de ações e instrumentos para implantação do Piso Salarial Profissional Nacional 
3.3 Propostas alternativas para a política de valorização dos professores do magistério da educação básica no contexto do segundo mandato da Presidente Dilma Rousseff............... 141

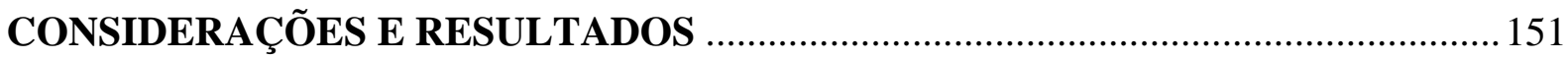

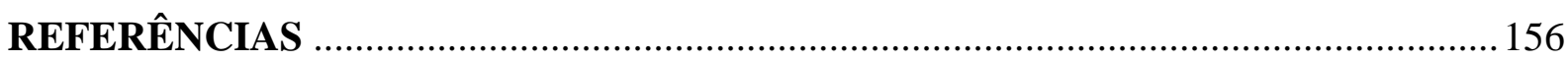

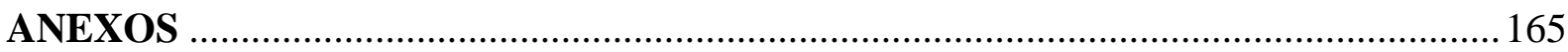




\section{INTRODUÇÃO}

Este estudo apresenta a pesquisa realizada no curso de mestrado profissional no campo da educação na Faculdade de Educação (FE) da Universidade de Brasília (UnB), Área de Políticas Públicas e Sistemas Educacionais, tendo como objeto a instituição do Piso Salarial Profissional Nacional (PSPN) por meio da Lei Federal n ${ }^{\circ} 11.738$, sancionada em 16 de julho de 2008, para valorizar os profissionais do magistério público da educação básica no país.

A opção por esse objeto de estudo deu-se no contexto das discussões, assessoramentos, monitoramentos, avaliações, diagnósticos, encaminhamentos técnicos e decisões políticas, que constituem a rotina da Diretoria de Valorização dos Profissionais da Educação (Divape) da Secretaria de Articulação com os Sistemas de Ensino (Sase) do Ministério da Educação (MEC). Entretanto, a transformação dessa opção em objeto de estudo acadêmico somente foi possível por meio do Termo de Cooperação (TC) n ${ }^{o}$ 1/2011 - Processo $n^{\circ}$ 23000.000105/2011-25, celebrado entre o Ministério da Educação e a Fundação Universidade de Brasília (FUB), em 30.05.2011, cuja finalidade é ofertar curso de Mestrado Profissional em Educação no Programa de Pós-Graduação em Educação (PPGE) da Faculdade de Educação (FE) da Universidade de Brasília (UnB), na Área de Políticas Públicas e Sistemas Educacionais. Assim, em pareceria, os dois órgãos do governo federal promovem a qualificação de servidores pertencentes aos seus quadros para atuarem em políticas implantadas pelo Estado brasileiro, em favor da educação pública com qualidade social.

Desde o início da década de 1980 até hoje, sou servidor do quadro permanente de pessoal do Ministério da Educação e a partir de 2011 a Divape/Sase tem sido o espaço institucional no qual desenvolvo ações técnico-profissionais no serviço púbico federal. A Divape/Sase tem por objetivo planejar e desenvolver atividades de apoio à implementação do PSPN e dos Planos de Carreira e Remuneração (PCR) de modo articulado com os entes federados.

A partir da sanção da Lei 11.738/2008, a articulação com os entes federados para instituição do PSPN passou a ser capitaneada pelo MEC, nos marcos do pacto federativo disposto na Constituição Federal (CF) de 1988. No âmbito do MEC, a tarefa de articular a instituição do PSPN passou a ser da Sase, criada pelo Decreto $n^{\circ} 7.480$, de 16 de maio de 2011, que assim dispõe em seu Art. 31, inciso VI: 
A Sase tem por atribuição, dentre outras, promover a valorização dos profissionais da educação, apoiando e estimulando a formação inicial e continuada, a estruturação da carreira e de remuneração e as relações de trabalho. (BRASIL, 2011).

Investida dessa atribuição, a Sase, por meio da Divape, passou a planejar e executar ações em sintonia com a Meta 17 do Projeto de Lei (PL) $n^{\circ}$ 8.035, de 20 de dezembro de 2010, o Plano Nacional de Educação - PNE 2014/2024, que trata da valorização dos profissionais do magistério público da educação básica na perspectiva de construção do Sistema Nacional de Educação - SNE:

Meta 17: valorizar os(as) profissionais do magistério das redes públicas de educação básica de forma a equiparar seu rendimento médio ao dos(as) demais profissionais com escolaridade equivalente, até o final do sexto ano de vigência deste PNE. (BRASIL, 2010).

O referido Projeto, depois de tramitar por três anos e meio no Congresso Nacional (CN), finalmente foi aprovado e transformado na Lei 13.005, de 25 de junho de 2014, que aprova o Plano Nacional de Educação 2014 - 2024.

Foi, portanto, no contexto da rotina da Divape/Sase/MEC e com respaldo no pacto acadêmico-institucional entre MEC e UnB, que as condições reais e objetivas para a realização do presente estudo foram criadas.

A proposta de instituição do PSPN vem de longas datas e remonta à Lei Geral que consiste na primeira Lei relativa ao Ensino Elementar. Esta Lei, outorgada por Dom Pedro I, veio se tornar um marco na educação do Império, de modo que passou a ser a principal referência para os docentes do primário e ginásio nas províncias. A Lei tratou dos mais diversos assuntos como descentralização do ensino, currículo mínimo, admissão de professores e escolas das meninas e remuneração dos professores e mestras. (BRASIL, 1827).

A questão da remuneração dos professores da educação básica desde o período imperial ao tempo republicano vem sendo um dos gargalos da política educacional brasileira. O Imperador, ao outorgar a Lei de 15 de outubro de 1827, formalmente, tratou dos salários dos professores. No artigo $3^{\circ}$ da Lei imperial, Dom Pedro I determinou que os presidentes, em Conselho, deviam taxar interinamente os ordenados dos professores, regulando-os de $200 \$ 000$ a 500\$000 anuais, com atenção às circunstâncias da população e carestia dos lugares.

A instituição do PSPN vem se arrastando ao longo do tempo e só foi resolvida graças à luta dos educadores nesses quase dois séculos de história da educação brasileira. Os professores com outras categorias da educação básica sempre lutaram pela aprovação do 
PSPN com o objetivo de valorizar e defender o pagamento de salários que respeitem a sua dignidade pelo trabalho que realizam nas escolas. Entretanto, foi somente em 2008, no segundo mandato do Presidente Luiz Inácio Lula da Silva, que a luta dos professores tornouse uma conquista, por meio da sanção da Lei 11.738/2008, que regulamentou a alínea "e" do inciso III do caput do art. 60 do Ato das Disposições Constitucionais, instituindo o PSPN para os profissionais do magistério público da educação básica (BRASIL, 2008).

A Lei 11.738/2008 expressa e assegura o que dispõe a Constituição Federal (CF) de 1988, que em seu art. 206, estabelece como primordial a estipulação do piso salarial para valorização dos profissionais da educação e consequentemente a melhoria nas redes de ensino, nestes termos:

Art. $206^{\circ} \mathrm{O}$ ensino será ministrado com base nos seguintes princípios:

[...]

V - valorização dos profissionais da educação escolar, garantidos na forma da lei, planos de carreira, com ingresso exclusivamente no concurso público de provas e títulos, aos das redes públicas. (Redação dada pela Emenda Constitucional $n^{\circ} 53$ de 2006). (BRASIL, 2008).

$[\ldots]$

VIII - piso salarial profissional nacional para os profissionais da educação escolar pública, nos termos da lei federal. (Incluído pela Emenda Constitucional $n^{\circ} 53$ de 2006). (BRASIL, 2008).

Em sintonia com a CF de 1988, a Lei de Diretrizes e Bases da Educação Nacional LDB - Lei $n^{\circ}$ 9.394/96 - discorre em seu art. 67 sobre a valorização do magistério, determinando que os sistemas de ensino promovam a valorização dos profissionais da educação, assegurando-lhes, inclusive nos termos dos estatutos e dos planos de carreira do magistério público, os seguintes direitos:

\footnotetext{
I - ingresso exclusivamente por concurso público e de provas de títulos;

II - aperfeiçoamento profissional continuado, inclusive com licenciamento periódico remunerado para este fim;

III - piso salarial profissional;

IV - progressão funcional baseada na titulação ou habilitação, e na avaliação de desempenho;

$\mathrm{V}$ - período reservado a estudo, planejamento e avaliação, incluído na carga de trabalho;

VI - condições adequadas de trabalho. (BRASIL, 1996).
}

No período compreendido entre a promulgação da CF de 1988 e da LDB de 1996, a questão da valorização dos profissionais da educação pública foi inserida no Plano Decenal de Educação para Todos - 1993/2003 - que definiu como meta: 
[...] aumentar progressivamente a remuneração do magistério público, através de plano de carreira que assegure seu compromisso com a produtividade do sistema, ganhos reais de salários e a recuperação de sua dignidade profissional e do reconhecimento público de sua função social. (BRASIL, 1993)

A sanção da Lei 11.738/2008, ao instituir o PSPN, veio consolidar o que dispõem a CF de 1988, a LDB de 1996 e Plano Decenal de Educação para Todos - 1993/2003, no sentido de valorizar os profissionais da educação básica. É o resultado de um amplo debate e muitos embates envolvendo entidades e movimentos da sociedade civil, gestores das três esferas de governo e o Congresso Nacional em torno de dois Projetos de Lei (PLs), sendo um oriundo do MEC, e outro do Senado Federal - o PL n ${ }^{\circ} 7.431 / 2006$, que tramitavam por um longo tempo no Congresso Nacional.

A Lei 11.738/2008 está estruturada em poucos artigos, fixa o PSPN dos profissionais da educação básica, afirma que este piso salarial deve ser pago por uma determinada jornada de trabalho, incluindo um tempo assegurado para elaboração de suas aulas e preparação de outras atividades que envolvem a sua função. Em seu art. $2^{\circ}, \S 1^{\circ}$, a referida Lei assim define piso salarial profissional:

Art. $2^{\circ}[\ldots]$

$\S 1^{\circ} \mathrm{O}$ piso salarial profissional é o valor abaixo do qual a União, os Estados, o Distrito Federal e os Municípios não poderão fixar o vencimento inicial das carreiras do magistério público da Educação Básica, para jornada de, no máximo quarenta (40) horas semanais. (BRASIL, 2008).

No $\S 4^{\circ}$ do mesmo art., a composição da jornada de trabalho assim é definida:

Art. $2^{\circ}[\ldots]$

$\S 4^{\circ} \mathrm{Na}$ composição da jornada de trabalho, observar-se-á ao limite de $2 / 3$ (dois terços) da carga horária para o desempenho das atividades de interação com os educandos. (BRASIL, 2008).

É importante frisar que os conceitos de piso salarial e de profissionais da educação são de abrangência nacional no art. $2^{\circ}$ da Lei 11.738/2008, para propiciar maior isonomia no país, e sua incidência se dá sobre os profissionais habilitados em nível médio, na modalidade normal, atuantes nas redes públicas de educação básica da União, dos Estados, dos municípios e do Distrito Federal (DF). Assim, três elementos são contemplados nesses conceitos: salário, formação e jornada de trabalho. Ao mesmo tempo, para a existência de uma escola com qualidade social são requisitos importantes as inter-relações entre a organização do currículo, do trabalho e da jornada de trabalho do professor, tendo como objetivo a aprendizagem do educando. (BRASIL, 2010). 
Desse modo, a Lei 11.738/2008 ou Lei do Piso determinou que o Piso Salarial Profissional Nacional deve ser igual a R \$ 950,00 mensais (valor à época da publicação da Lei) e pago uma jornada de até 40 horas semanais (e proporcional nos demais casos), sendo que esta jornada deve disponibilizar 2/3 (dois terços) para os professores prepararem suas aulas e outras atividades de interação com os educandos. A Lei do Piso também definiu que este valor deve ser atualizado anualmente utilizando-se como referência o percentual de crescimento do valor anual mínimo por aluno referente aos anos iniciais do ensino fundamental urbano, o qual é definido nacionalmente nos termos da Lei 11.494 - Fundeb -, de 20 de junho de 2007. Neste ano, com base na aplicação dessa metodologia, o valor do Piso Salarial Profissional Nacional já é de R \$ 1.917,78 (mil novecentos e dezessete reais e setenta e oito centavos).

Mesmo sendo alicerçada na CF de 1988, na LDB de 1996, no Plano Decenal de Educação para Todos - 1993/2003, e resultante de muitos debates e embates envolvendo a sociedade civil e os três poderes da República e, principalmente, da luta histórica dos profisssionais da educação básica, ou seja, considerada relevante para o avanço da educação no país, a Lei 11.738/2008 foi contestada junto ao Supremo Tribunal Federal (STF), por meio da Ação Direta de Inconstitucionalidade (ADI), impetrada pelos governos estaduais de Mato Grosso do Sul, Rio Grande do Sul, Paraná, Ceará e Santa Catarina, ainda no ano de 2008. A ação foi apoiada também por outros cinco governadores dos estados de Roraima, São Paulo, Tocantins, Minas Gerais e Distrito Federal.

Os estados questionaram, na sua ação, o estabelecimento da jornada de no máximo 40 horas semanais de trabalho, a composição da jornada, a vinculação do Piso Salarial Profissional Nacional ao vencimento inicial das carreiras dos professores (não se admitindo computar gratificações, bônus e outros adicionais), os prazos para a implementação e a data da vigência dada à Lei do Piso. A rigor, contestaram a legitimidade da União para legislar sobre esta questão, alegando que a fixação do regime de trabalho dos servidores estaduais e municipais, pelo pacto federativo, caberia à essas esferas do Estado, argumentando que os custos gerados pela Lei do Piso representaria risco às finanças dos entes federados.

Em atendimento parcial à ADI impetrada pelos governadores, em 17 de dezembro de 2008, o STF proferiu medida cautelar que suspendeu provisoriamente dois pontos fundamentais da Lei: a composição da jornada de trabalho e a vinculação do Piso Salarial Profissional Nacional ao vencimento inicial da carreira, passando a ser referência para o pagamento do piso salarial a remuneração e não o vencimento inicial dos profissionais do magistério da educação básica. 
Essa ADI foi superada por decisão definitiva do STF, em dois julgamentos consecutivos, realizados em 6 e 27 de abril de 2011. No primeiro julgamento, a decisão dos juízes foi unânime pela constitucionalidade da Lei $n^{\circ}$ 11.738/2008 no que tange à instituição do PSPN. No segundo julgamento, a decisão apresentou um empate no resultado - cinco x cinco votos - para a composição da jornada de trabalho. O STF decidiu pela constitucionalidade integral da Lei $11.738 / 2008$ e a sua aplicação obrigatória por todos os entes federados. Entretanto, nem todos os entes federados vêm cumprindo o que determina a Lei do Piso, conforme levantamento de informações realizado pela Divape/Sase/MEC acerca do não apgamento do PSPN nos estados e capitais, em março de 20915.

O descumprimento da aplicação da Lei do Piso tem ensejado enfrentamento entre os representantes e integrantes do magistério da educação básica e os governos estaduais e municipais, seja pelo valor do PSPN, seja pela composição da jornada de trabalho, ou outras questões de interesses dos professores. Como exemplo, as greves de professores e os processos judiciais que vêm ocorrendo nos entes federados após a sanção da Lei 11.738/2008, conforme levantamento de dados armazenados nos arquivos da Divape/Sase/MEC.

A Lei 11.738/2008 é uma ação política do Estado, considerada necessária ao avanço da política de valorização dos profissionais do magistério da educação básica e da melhoria da qualidade de ensino e, como tal, não pode ser ignorada ou descumprida pelos entes federados. Por isso cabe a todos os órgãos do Estado brasileiro cumprí-la e fazê-la cumprir, para não transformar em letra morta o resultado de uma luta histórica dos professores e da conjugação de esforços das autoridades educacionais, gestores, profissionais da educação e outros segmentos sociais envolvidos com a qualidade da educação e com direitos das crianças e jovens no país. Esta é a lógica do Estado ao instituir o PSPN.

Isto posto, elegeu-se como objetivo geral analisar a instituição do Piso Salarial Profissional Nacional (PSPN) como ação política implantada pelo Estado, por meio da sanção da Lei 11.738/2008, para explicitar a relevância atribuída ao elemento econômico e financeiro na valorização dos professores do magistério público da educação básica, ao mesmo tempo, desvelar o quanto esse sentido de valorização simplifica a potencialidade do trabalho docente no âmbito da ordem capitalista vigente no país. Nessa linha de raciocínio, adotou-se como questão norteadora: a instituição do Piso Salarial Profissional Nacional por meio da Lei 11.738/2008 valoriza os professores da educação básica?

Em razão desse objetivo geral, buscou-se alcançar os seguintes objetivos específicos:

a) Analisar a inserção da Lei 11.738/2008 como uma ferramenta de valorização dos profissionais da educação básica na lógica do capital, sem considerar a potencialidade 
do trabalho docente nas escolas como categoria fundante do ser humano. A análise no primeiro capítulo norteou-se por esta questão: como se configura a inserção da Lei 11.738/2008 que institui o Piso Salarial Profissional Nacional na ordem capitalista vigente no país?

b) Analisar a instituição do piso salarial profissional na visão dos gestores educacionais federais e municipais, e dirigentes de entidade nacional e sindicais municipais de professores da educação básica, à luz das categorias analítico-filosóficas ideologia e alienação, para desvelar o quanto a valorização dos professores do magistério público da educação básica focada no elemento econômico e financeiro minimiza a potencialidade do trabalho educativo realizado pelos professores. No segundo capítulo, elegeu-se esta questão: como o sentido de valorização dos professores na instituição do piso salarial profissional se mostra positivo na visão dos gestores educacionais e dirigentes de entidades nacional e sindicais municipais e, ao mesmo tempo, contribui para simplificar a potencialidade do trabalho docente nas escolas?

c) Analisar as sugestões/propostas dos gestores educacionais federais e municipais, e dirigentes de entidade nacional e sindicais municipais de professores da educação básica e as ações realizadas pela Sase do MEC, consideradas como avanços na política de valorização dos professores da educação básica, para desocultar a simplificação do trabalho docente que se esconde no modo de ver e proceder desses sujeitos. A análise na primeira parte do terceiro capítulo norteou-se por esta questão: como as sugestões/propostas dos gestores e dirigentes e, igualmente, as ações realizadas pela Divape/Sase/MEC ampliam e reforçam a valorização dos professores da educação básica centrada na instituição do PSPN, ao mesmo tempo, servem para esconder a minimização da potencialidade do trabalho dos professores?

d) Analisar alguns avanços, conquistas e limites na instituição do Piso Salarial Profissional Nacional por meio da Lei 11.738/2008, para propor um balanço crítico da política de valorização dos professores da educação básica vigente e apontar dois caminhos alternativos ao desenvolvimento da referida política. A análise na segunda parte do terceiro capítulo orientou-se por esta questão: como se configuram alguns avanços, conquistas e limites na instituição do Piso Salarial Profissional Nacional, por meio da Lei 11.738/2008, e em que consistem os dois caminhos alternativos para o desenvolvimento da política de valorização dos professores da educação básica? 
$\mathrm{Na}$ perspectiva de alcançar esses objetivos, adotou-se a suspeita dialética como principal procedimento analítico. A suspeita dialética tem como ponto de partida o ser humano concreto, real, numa sociedade real, dada, historicamente situada e não a visão idealista de ser humano e sociedade. Considera-se a suspeita dialética como uma das atitudes mais nobres na busca do conhecimento humano. Neste estudo, assume-se a suspeita dialética como ato de liberdade e responsabilidade pelo qual o ser humano toma posição mediante às questões, às ideologias, aos dogmas, às posturas sectárias no mundo que o cerca, para derrotálas e retomar a situação em que vive, colocando-se como sujeito dela. Um ato, não uma ação entre outras; uma maneira de reerguer, de levantar a cabeça e fazer frente, caminhar e avançar. A suspeita dialética significa, assim, muitíssimo mais do que qualquer procedimento metodológico que possa ser usado de maneira neutra; ao contrário, ela consiste numa atitude existencial, portanto, uma maneira de ser ou existir na busca do conhecimento das coisas no mundo real, concreto. Por isso, consiste no ato de transcender as aparências ou o modo como as coisas, os fenômenos, os fatos, os objetos se mostram, desvelando e evidenciando as contradições, os mecanismos ideológicos, as falácias que os envolvem, com vistas à sua superação.

No campo da educação, a suspeita dialética esboça e propõe uma atitude de combater as ideologias, os dogmas, os sectarismos, as visões unilaterais que condicionam e assolam as ideias e práticas educativas, para a superação desses problemas. Enfim, além de exprimir aquilo que se faz, também aponta o que ainda precisa ser feito. A suspeita dialética foi adotada aqui como procedimento de análise, para facilitar a aproximação com o pensamento materialista, histórico e dialético do filósofo alemão Karl Heinrich Marx, que coloca sob suspeita dialética o sistema do capital e propõe a sua superação.

Karl Marx, nascido em 5 de maio de 1818 em Trévis, na Renânia (Prússia), de uma família judaico-alemã, batizado em uma igreja protestante, tornou-se conhecido por ter escrito O Manifesto do Partido Comunista (1848), A Ideologia Alemã (1845-46), Manuscritos Econômico-filosóficos (1844), em parceria com Friedrich Engels, e os volumes reunidos de O Capital (1867 - tomo I), os tomos II, III e IV saíram, respectivamente, em 1885, 1894 e 1905, com edições de Engels e Kaustsky, entre outros trabalhos que compõem a sua obra.

A obra Ideologia Alemã (1977) faz uma crítica à filosofia especulativa dos jovens hegelianos Ludwig Feuerbach, Max Stirner e Bruno Bauer. Marx e Engels (1977) argumentam que a tradição desse pensamento alemão, decorrente das ideias de Hegel, era conservadora e ficava restrita ao plano conceitual, descolada da práxis transformadora e revolucionária. A crítica de Marx e Engels repõe a questão da consciência humana na relação 
sujeito-objeto. O problema da consciência humana foi discutido por Marx no conjunto de sua obra e assim encontra-se presente em diversos escritos, tornando-se referência crítica à todas as formas de alienação e referência privilegiada de compreensão da história, da técnica, da ideologia e do devir na modernidade, abrindo possibilidades históricas de superação da filosofia especulativa pela filosofia da práxis. De fato, a questão da consciência foi apresentada de maneira sistematizada pela primeira vez por Marx e Engels em A Ideologia Alemã (1977). Ao analisarem a interpelação entre ideias dominantes e relações materiais dominantes, que definiriam o caráter da alienação e da ideologia na sociedade de classe, os autores afirmam que "[...] e se, em toda ideologia, os homens e suas relações aparecem invertidos como uma câmara escura, tal fenômeno decorre de seu processo histórico de vida."(MARX, 1977, p. 37).

Na obra Manuscritos Econômico-filosóficos (2002), também chamado de Manuscritos de 1844, Marx reúne uma série de textos com reflexões sobre economia, política e filosofia, sendo publicado somente nos anos de 1930. A alienação do trabalho, a propriedade privada, a divisão do trabalho, economia política e as relações mediadas pelo dinheiro estão entre os temas da obra, que é uma das chaves para se entender o percurso teórico de Marx.

Da aproximação com estas obras de Marx e Engels elegeu-se as categorias analíticofilosóficas alienação e ideologia para serem utilizadas neste estudo. Da obra Manuscritos Econômico-filosóficos (2002) utilizou-se a concepção de alienação que foi reelaborada por Marx ao ser tomado de Ludwig Feuerbach, assim como tinha sido reelaborado por Feuerbach depois de ter sido tomado de Hegel (1770 - 1831); antes vista apenas sobre o prisma filosófico, agora, nas mãos de Marx, a concepção de alienação passa a integrar o processo da vida econômica. Enquanto para Hegel a alienação é considerada como processo positivo para a vida do ser humano, para Marx trata-se de um processo negativo por inverter a realidade histórica e social; um processo por meio do qual a essência humana dos operários se objetivava nos produtos do seu trabalho e se contrapunha a eles por serem produtos alienados e convertidos em capital. Assim, o que antes era a ideia abstrata do ser humano que se criava a si mesmo por meio do trabalho - ideia recebida de Hegel - concretizava-se agora na observação crítica da sociedade burguesa real.

Do mesmo modo, da aproximação com as obras Ideologia Alemã, de1845-46 e O Capital, de1867 utilizou-se a concepção de ideologia formulada por Marx e Engels (1977). Em Ideologia Alemã a concepção de ideologia consiste numa crítica ao pensamento idealista hegeliano. Os idealistas hegelianos pensavam que bastava lançar um olhar crítico sobre o mundo para se alcançar a liberdade humana. Mas, ao focalizarem a religião, a moral, eles 
ocultavam as relações econômicas reais. Para Marx e Engels (1977), não são os pensamentos que governam o mundo, mas as relações de produção que condicionam as ideias. É uma ilusão própria a ideologia conhecer as ideias desconectadas de um contexto material histórico.

Assim, ao contrário da visão idealista, o materialismo histórico de Marx e Engels (1977) parte da realidade concreta e objetiva: as relações do ser humano com a natureza e com os outros seres humanos. O ser humano se caracteriza pelo fato de sua vida não ser determinada pela natureza, porque ele produz os meios de satisfazer suas necessidades. Esses meios, as forças de produção, permitem ao ser humano produzir riquezas e determinam, necessariamente, uma certa forma de repartição do trabalho e dos bens e determinam a sociedade civil. A evolução dos meios de produção condiciona a evolução da sociedade. Mais ainda, ela condiciona o modo de pensar de uma época. Por exemplo, o Estado é fruto da sociedade capitalista, ou seja, é a ficção pela qual a burguesia, cada vez mais poderosa, faz acreditar que num interesse coletivo, desejado, fruto de um contrato entre iguais, para dissimular melhor as desigualdades econômicas, sociais e políticas, para preservar seus interesses. O materialismo desvela essa ficção ao estudar a evolução das relações de produção, as relações reais entre os seres humanos, as riquezas e os bens, mostrando a correlação entre o econômico, o social, a política e as representações morais, jurídicas, filosóficas e assim por diante.

Em O Capital - tomo I (1867), Marx (1996) explora a teoria da mais-valia, as concepções de alienação, acumulação de capital, materialismo histórico, ideologia, dentre outras. A concepção de ideologia é formulada como uma questão marcadamente dirigida ao sistema de circulação de mercadorias. A circulação de mercadorias é o ponto de partida do capital. A produção de mercadorias e o comércio, forma desenvolvida da circulação de mercadorias, constituem as condições históricas que dão origem ao capital. O comércio e o mercado mundiais inauguram no século XVI a moderna história do capital. É posto de lado o conteúdo material da circulação de mercadorias a troca de diferentes valores de uso, para considerar apenas as formas econômicas engendradas por esse processo de circulação, encontra-se o dinheiro como produto final. Esse produto final da circulação das mercadorias é a primeira forma em que aparece o capital.

Assim, a questão da ideologia é formulada como aparência, ou seja, um modo mistificador que leva os seres humanos a perceberem socialmente a mercadoria como algo autônomo em que os produtos do cérebro humano parecem dotados de vida própria, figuras autônomas, que mantêm relações entre si e com os homens. A ideologia consiste em uma consciência indireta, construída e manipulada pela classe dominante. E sempre de acordo com 
os interesses dessa classe; trata-se, portanto, de uma consciência equivocada: enquanto na visão idealista são as ideias que dão a forma da vida material, a vida concreta da sociedade, para o pensamento materialista histórico a ideologia é a expressão mistificada, a tradução de interesses materiais implícitos nas relações materiais da sociedade. As transformações sociais encontram suas raízes nas diferentes relações das forças de produção; e não o contrário. $\mathrm{Na}$ perspectiva do materialismo histórico, portanto, a ideologia é uma visão distorcida da realidade histórica, construída pela classe dominante com a finalidade de conservar o seu poder.

Em sintonia com as categorias do método, elegeu-se como categoria do campo empírico a valorização do trabalho docente, levando-se em conta que a positividade que envolve a valorização dos profissionais da educação básica e da forma como é proclamada pelos gestores federais e municipais, dirigentes de entidade nacional e sindicais municipais de professores, serve para ocultar a simplificação da potencialidade do trabalho docente nas escolas públicas. Dito de outro modo, o sentido positivo da valorização dos profissionais do magistério da educação básica serve como mecanismo de ocultação do real sentido do trabalho docente e da essência da existência dos professores enquanto seres humanos nas escolas e noutros ambientes educacionais.

Explicitadas as categorias do método e do campo empírico, pontua-se a concepção de especificidade do trabalho educativo utilizada como referência na análise do objeto estudado, extraída de Noronha:

Os professores das redes públicas, a exemplo dos demais trabalhadores do setor
público, vendem sua força de trabalno para o Estado. Seu trabalho, assim, não está
diretamente vinculado à valorização do capital, não representa um investimento
capitalista na produção de mercadorias e, portanto, não produz mais-valia.
Entretanto, seu trabalho é diretamente afetado pela forma como está organizado o
sistema capitalista e é por ele influenciado e tende a ser por ele dirigido. [...] A
educação no setor público, diferentemente de outras áreas da atividade humana, não
produz mercadorias - forma pessoas. Ela tem no ser humano seu ponto de partida e
seu ponto de chegada, pois embora o processo educativo seja mediado por meios
materiais, como as estruturas das escolas, equipamentos, materiais pedagógicos e
outros, é na relação humana que ele se realiza. Por isso, para além de qualquer outra
melhoria estrutural, embora importante, o foco das ações para aprimorar o processo
educativo deve estar no desenvolvimento de políticas que valorizem o trabalho do
professor e signifiquem melhor aprendizagem para os estudantes. (NORONHA,
2012, p. 13).

Em sintonia com a formulação de Noronha, Frigotto assim se expressa em relação à especificidade do trabalho docente:

[...] Muito se escreveu sobre o caráter produtivivo ou improdutivo do trabalho docente. Como Marx exemplificou que somente o trabalho docente regulado pelo 
assalariamento privado é produtivo, muitos concluíram apressadamente que o trabalho dos docentes do setor público, por ser improdutivo, está afastado das injunções do capital e que o problema nodal da valorização do trabalho docente tem de ser buscado quase que excluviamnte no cotidiano da escola e no campo pedagógico. Mas a questão não é simples assim, pois o trabalho improdutivo segue sendo vital para a reprodução do capital. (FRIGOTTO, 2004, p.64)

Isto posto, apresenta-se a metodologia e seus procedimentos na captação e análise dos dados empíricos. Foram realizadas nove entrevistas semiestruturadas com gestores educacionais do governo federal (secretário, diretor e coordenador-geral na Sase/MEC); gestores educacionais municipais ( ex-secretária e secretários de educação dos municípios de Santarém - PA e Cidade Ocidental - GO); e dirigente de entidade nacional na Confederação Nacional de Trabalhadores da Educação (CNTE), e de entidades sindicais de professores nos municípios de Santarém e Cidade Ocidental.

Adotou-se como critérios para escolha dos gestores educacionais federais e municipais, dirigentes de entidade nacional e sindicais municipais de professores:

a) as manifestações de envolvimento e compromisso com a instituição do piso salarial profissional, planos de carreira em favor da valorização dos profissionais da educação básica;

b) são todos professores efetivos da educação básica; e

c) foram (no caso dos gestores federais e municipais) ou são (no caso dos dirigentes de entidade nacional e sindicais municipais) representantes de entidades defensoras dos interesses dos profissionais da educação básica. Esses critérios expressam o envolvimento desses sujeitos na luta histórica pela valorização dos professores da educação pública.

Para escolha das redes de ensino dos municípios de Santarém e Cidade Ocidental, quatro critérios foram adotados:

a) o envolvimento no processo de instituição do PSPN;

b) o envolvimento na implantação da Lei 11.738/2008;

c) os dois entes federados, dentro de suas condições e dificuldades, passaram a pagar o PSPN;

d) a conexão necessária entre a rotina da Divape/Sase/MEC em prestar assistência técnica in loco às Secretarias de Educação dos municípios de Santarém e Cidade Ocidental para instituição do PSPN e implementação dos planos de carreira dos professores com o tempo de realização das entrevistas com gestores educacionais municipais e dirigentes sindicais nesses entes federados, resultando em racionalização de gastos públicos.

O Quadro 01 apresenta os gestores educacionais federais e municipais, e os dirigentes de entidade nacional e sindicais municipais de professores que foram entrevistados no período de 21.11.2012 a 19.02.2013. 
Quadro 01: Gestores educacionais federais e municipais, dirigentes de entidade nacional e sindicais municipais entrevistados

\begin{tabular}{|c|c|c|c|c|c|c|}
\hline Blocos & Tipos & Instituição & Função & Formação & $\begin{array}{l}\text { Código do } \\
\text { anonimato }\end{array}$ & Qde \\
\hline \multirow{3}{*}{ A } & \multirow{3}{*}{$\begin{array}{l}\text { Gestores } \\
\text { Educaionais } \\
\text { Federais }\end{array}$} & Sase/MEC & Secretário & $\begin{array}{l}\text { Mestrado em } \\
\text { planejamento da } \\
\text { educação }\end{array}$ & $\begin{array}{l}\text { Gestor } \\
\text { Federal } 1\end{array}$ & 01 \\
\hline & & Divape/Sase/MEC & $\begin{array}{l}\text { Coordenador- } \\
\text { Geral }\end{array}$ & Doutorado em educação & $\begin{array}{l}\text { Gestor } \\
\text { Federal } 2\end{array}$ & 01 \\
\hline & & Divape/Sase/MEC & Diretor & $\begin{array}{l}\text { Pós-graduado em } \\
\text { História }\end{array}$ & $\begin{array}{l}\text { Gestor } \\
\text { Federal } 3\end{array}$ & 01 \\
\hline \multirow{3}{*}{$\mathrm{B}$} & \multirow{3}{*}{$\begin{array}{l}\text { Gestores } \\
\text { Educacionais } \\
\text { Municipais }\end{array}$} & \multirow{3}{*}{$\begin{array}{l}\text { Semed/Santarém } \\
\text {-PA e } \\
\text { Semed/Cidade } \\
\text { Ocidental - GO }\end{array}$} & $\begin{array}{l}\text { Ex-secretária } \\
\text { municipal }\end{array}$ & $\begin{array}{l}\text { Professora de ensino } \\
\text { superior }\end{array}$ & $\begin{array}{l}\text { Gestor } \\
\text { Municipal } 1\end{array}$ & 01 \\
\hline & & & $\begin{array}{l}\text { Assessor de } \\
\text { Gabinete }\end{array}$ & $\begin{array}{l}\text { Professor da rede } \\
\text { municipal de ensino }\end{array}$ & $\begin{array}{l}\text { Gestor } \\
\text { Municipal } 2\end{array}$ & 01 \\
\hline & & & $\begin{array}{l}\text { Secretário } \\
\text { muncipal }\end{array}$ & $\begin{array}{l}\text { Secretário municipal de } \\
\text { educação }\end{array}$ & $\begin{array}{l}\text { Gestor } \\
\text { muncipal } 3\end{array}$ & 01 \\
\hline \multirow{3}{*}{$\mathrm{C}$} & $\begin{array}{l}\text { Dirigente } \\
\text { Nacional }\end{array}$ & CNTE & Diretor & $\begin{array}{l}\text { Professor da rede } \\
\text { estadual de ensino }\end{array}$ & $\begin{array}{l}\text { Dirigente } \\
\text { Nacional } 1\end{array}$ & 01 \\
\hline & $\begin{array}{l}\text { Dirigentes } \\
\text { Municipais }\end{array}$ & $\begin{array}{l}\text { Sindicato de } \\
\text { Professores de } \\
\text { Santarém - PA }\end{array}$ & Diretor & $\begin{array}{l}\text { Professor da rede } \\
\text { municipal de ensino }\end{array}$ & $\begin{array}{l}\text { Dirigente } \\
\text { Municipal } 1\end{array}$ & 01 \\
\hline & & $\begin{array}{l}\text { Sindicato de } \\
\text { Cidade Ocidental- } \\
\text { GO }\end{array}$ & Diretor & $\begin{array}{l}\text { Professora da rede } \\
\text { municipal de ensino }\end{array}$ & $\begin{array}{l}\text { Dirigente } \\
\text { Municipal } 2\end{array}$ & 01 \\
\hline Total & & & & & & 09 \\
\hline
\end{tabular}

Fonte: Elaborado pelo autor, a partir de entrevistas semiestruturadas no período de 21.11.2012 a 19.02.2013.

Além das entrevistas realizadas com gestores federais e municipais, e dirigentes de entidade nacional e sindicais municipais de professores, recorreu-se a outras fontes de informações como arquivos e pastas da Divape/Sase, de outros órgãos do MEC como o Sistema de Informações do MEC (Simec) e do governo federal; arquivos das Secretarias Municipais de Educação e sindicatos de professores dos municípios de Santarém e Cidade Ocidental; arquivos da Confederação Nacional dos Trabalhadores em Educação; legislações vigentes (decretos, portarias, resoluções, pareceres, dentre outros) emitidas pela Câmara Federal dos Deputados e Senado Federal, Conselho Nacional de Educação (CNE).

Assim, tendo como suporte as categorias analítico-filosóficas ideologia e alienação, as informações resultantes das entrevistas semiestruturadas e dos documentos em arquivos de instituições públicas, o presente estudo busca ser uma contribuição ao conhecimento da PSPN, instituído pela Lei 11.738/2008, considerada uma ação política do Estado para valorizar os professores da educação básica no país. 
No contexto acadêmico, ressalta-se a existência de estudos realizados sobre oobjeto deste estudo. Entretanto, em geral, eles focam a evolução histórica do PSPNl, com ênfase na relevância econômica e financeira para a valorização dos docentes. É o caso destas pesquisas: O Papel do Piso Salarial Profissional Nacional como instrumento de valorização dos professores da educação básica pública, de João Antonio Cabral de Monlevade (2000), dentro do Programa de Pós-graduação em Educação da Universidade Federal de Campinas; Piso Salarial para os Educadores Brasileiros: quem toma partido?, de Juçara Maria Dutra Vieira (2012), dentro do Programa de Pós-graduação em Educação da Universidade de Brasília; Avaliação do Impacto da Lei do Piso Salarial Profissional Nacional para os profissionais do magistério público da educação básica sobre a proficiência dos alunos das redes públicas brasileiras, realizada por Geraldo Andrade da Silva Filho (2012), dentro do Programa de PósGraduação em Economia da Fundação Getúlio Vargas; Piso Salarial Profissional Nacional do Magistério: conflitos e limites de sua implementação na rede pública estdual de Goiás, de Jarbas de Paula Machado (2010), dentro do Programa de Pós-graduação em Educação da Universidade Federal de Goiás; Perfil Profissional e Condições do Trabalho Docente - um estudo sobre os professores dos anos iniciais da RME de Curitiba, de Aline Chalus Vernick Carissimi (2011), dentro do Programa de Pós-graduação em Educação da Universidade Federal do Paraná.

O presente estudo se diferencia dessas e de outras pesquisas quanto ao foco sobre o objeto em questão, na medida em que busca analisar a necessidade e relevância que são atribuídas à valorização econômica e financeira dos professores do magistério público da educação básica, mas, ao mesmo tempo, procura desvelar o quanto esse sentido de valorização simplifica, minimiza, reduz a potencialidade do trabalho docente no âmbito da ordem capitalista vigente no país. Além disso, sugere a realização de um balanço crítico da política de valorização dos professores e aponta dois caminhos alternativos para o desenvolvimento da mesma. Busca ser uma abordagem qualitativa do sentido de valorização contido no PSPN.

Sob o aspecto político, este estudo vislumbra a possibilidade dos seus resultados serem usados como subsídios à uma avaliação dianóstica da política de valorização dos professores da educação básica vigente e ao conhecimento de duas propostas alternativas ao desenvolvimento da mesma. Vislumbra-se, ainda, a prspectiva de a Divape/Sase e outros órgãos do MEC, tais como Secretaria de Educação Básica (SEB), Secretaria de Educação Continuada, Alfabetização, Diversidade e Inclusão (Secadi) - utilizarem os resultados deste 
estudo na melhoria da qualidade da educação básica, levando em conta a necessidade de valorização do trabalho docente nas escolas.

No campo social, ressalta-se o impacto positivo do estudo na formação teórico-prática do mestrando-pesquisador enquanto ser humano e trabalhador no campo da educação, durante o mestrado profissional. Assumiu-se uma postura teórico-prática fundada num processo dialético: objetivação sistematizada e crítica sobre um determinado objeto para devolvê-lo à sua realidade empírica original em forma de objeto refletido, propondo ações de reestruturação da política de valorização dos professores da educação básica vigemte. Assim, vislumbra-se a perspectiva de o estudo ser usado em favor da formação teórico-prática de técnicos e gestores federais,estaduais e municipais, de instituições públicas e sindicais e dos próprios professores.

O estudo foi estruturado em três (3) capítulos que problematizam a instituição do PSPN, focando esta questão: a instituição do Piso Salarial Profissional Nacional por meio da Lei 11.738/2008 valoriza os professores do magistério da educação básica?

O primeiro capítulo denominado A Inserção da Lei $n^{o}$ 11.738/2008 na ordem capitalista vigente no país analisa a inserção da Lei 11.738/2008 como uma ferramenta de valorização dos profissionais da educação básica na lógica do capital, sem levarem em conta a potencialidade do trabalho docente nas escolas como categoria fundante do ser humano.

O segundo capítulo sob a designação A implementação da Lei 11.738/2008, valorização e plano de carreira na visão dos gestores educacionais federais e municipais, dirigentes de entidade nacional e sindicais municipais de professores faz uma análise da instituição do PSPN na visão dos gestores educacionais federais e municipais, e dirigentes de entidade nacional de sindicais municipais de professores da educação básica, à luz das categorias analíticofilosóficas ideologia e alienação, para desvelar o quanto a valorização dos professores do magistério público da educação básica focada no elemento econômico e financeiro minimiza a potencialidade do trabalho educativo realizado pelos professores.

O terceiro capítulo intitulado A implementação da Lei 11.738/2008: conquista, avanços e limites analisa as sugestões/propostas dos gestores educacionais federais e municipais, e dirigentes de entidade nacional de sindicais municipais de professores consideradas avanços na política de valorização dos professores da educação básica e, igualmente, as ações realizadas pela SASE/MEC, para desocultar a simplificação do trabalho docente que se esconde na visão e procedimento desses sujeitos. Propõe, ainda, um balanço crítico da política de valorização dos professores da educação básica vigente e aponta dois caminhos alternativos ao desenvolvimento da mesma. 
CAPÍTULO 1 - A Lei 11.738/2008 como ferramenta de valorização dos profissionais da educação básica na lógica do capital

Como se configura a inserção da Lei 11.738/2008 na ordem capitalista vigente no país?

Este capítulo analisa o sentido da inserção da Lei 11.738/2008 como uma ferramenta para valorizar os profissionais da educação básica do ponto de vista econômico e financeiro na lógica do capital, ocultando a potencialidade do trabalho docente nas escolas públicas como categoria fundante do ser humano.

O capítulo estrutura-se em quatro itens, nos quais se explicitam aspectos pertinentes na ordem capitalista vigente no país: (1) o contexto histórico da Lei 11.738/2008, levando-se em conta o tempo da nova gestão pública; (2) a valorização dos profissionais da educação básica na Constituição Federal de 1988 e em legislação infraconstitucional; (3) a Lei 11.738/2008 como um instrumento da política de valorização dos profissionais da educação básica; e (4) a instituição do PSPN como expressão política do Estado.

\subsection{A inserção da Lei $11.738 / 2008$ na política de valorização dos profissionais da educação básica: Estado democrático nos marcos da ordem capitalista vigente no país}

Na história da educação brasileira, a intenção de instituir o Piso Salarial Profissional Nacional dos professores do magistério público da educação básica vem de longas datas. $\mathrm{O}$ Decreto-Lei de Dom Pedro I, de 15 de outubro de 1827, que tratava da primeira Lei Geral relativa ao ensino no Brasil (currículo, admissão de professores, escolas das meninas e remuneração dos professores) transformou-se na principal referência para os professores do primário e do ginásio nas províncias, estabelecendo um valor mínimo e um valor máximo que deveriam ser pagos a eles. (MONLEVADE, 2000).

No art. $3^{\circ}$ do referido Decreto (1827), o Imperador assim determinou:

os presidentes, em Conselho, taxarão interinamente os ordenados dos professores, regulando-os de $200 \$ 000$ e 500\$000 anuais, com atenção às circunstâncias da população e carestia dos lugares, e o farão presente a Assembléia Geral para a aprovação.

Esse fato tem sido utilizado como ponto de partida para estudos no campo da educação brasileira, que focam geralmente a evolução histórica do piso salarial, com ênfase sobretudo 
no elemento econômico e financeiro para valorização dos docentes. É o caso do estudo realizado por Monlevade, que aponta para essa questão:

os atuais dois milhões de professores e professoras que trabalham na educação
infantil, educação fundamental e no ensino médio nas escolas públicas estaduais e
municipais no Brasil são herdeiros de uma história que começa em 1551, com a
chegada dos jesuítas à Bahia. [...] Sua valorização como professores não advinha,
contudo, de altos salários, mesmo porque eles não viviam de salários, mas de rendas
auferidas principalmente de vendas de gado de suas fazendas, trabalhadas por
escravos e administradas pelos religiosos irmãos coadjutores. (MONLEVADE,
2000, p. 4)

Seguem também essa linha de abordagem estudos organizados por Azevedo, Oliveira e Vieira (2012); Ferreira, Oliveira e Vieira (2012); Maués et al (2012); Oliveira e Vieira (2012); Oliveira et al (2012); Duarte et al (2012), dentre outros. Neste estudo, optou-se por um marco histórico mais recente: a promulgação da Constituição Federal de 1988 e a legislação infraconstitucional dela decorrente. Optou-se também por uma abordagm qualitativa do sentido da instituição do PSPN como ação política do Estado para valorizar os professores do magistério da educação básica. Buscou-se, então, analisar o significado da inserção da Lei 11.738/2008 no contexto histórico pós ditadura militar de 1964, marcado por novas relações democráticas do Estado com a sociedade civil, dentro da ordem econômica reguladora da sociedade brasileira.

Neste ponto, busca-se compreender a concepção de Estado para o entendimento desse novo cenário político a partir da promulgação da CF de 1988. Recorre-se à ideia marxista de Estado desenvolvido por Marx diretamente relacionada à concepção de sociedade. Na visão marxista, o Estado não está acima da sociedade civil e não exprime a vontade de todos, mas é uma instância inserida no conjunto de relações estabelecidadas entre pessoas, grupos e classes sociais. De acordo com Ianni é necessário que se reconheça que

Sob qualquer das suas perspectivas, desde seus primeiros escritos, Marx está
preocupado com as relações de determinações recíprocas entre o Estado e a
sociedade, numa ótica diferente daquelas propostas anteriormente, não apenas por
Hegel. Nesse processo crítico, formula a chave da sua concepção, quando diz que o
Estado precisa ser compreendido, simultaneamente, como uma "colossal
superestrutura" do regime capitalista e como "poder organizado de uma classe"
social em sua relação com as outras. (IANNI, 1996, p. 30)

No entendimento de Ianni, Marx afirma que o Estado e a sociedade não são politicamente distintos, pois, que além de ser a estrutura da sociedade, ele não é a expressão harmônica e abstrata desta. Ao contrário, constitui-se como um produto de contradições políticas, sendo a primeira delas o fato de ele basear-se na contradição entre o público e a vida privada, entre o interesse geral e o particular. 
Ainda no entendimento de Ianni, para Marx,

O Estado não é apenas e exclusivamente, um órgão; responde também aos movimentos do conjunto da sociedade e das outras classes sociais, segundo, é óbvio, as determinações das relações capitalistas. Conforme o grau de desenvolvimento das forças produtivas, das relações de produção e das forças políticas da sociedade, o Estado pode adquirir contornos mais ou menos nitidos, revelar-se mais ou menos diretamente vinculado aos interesses exclusivos da burguesia. (IANNI, 1996, p. 39).

A ideia de Estado formulada por Marx foi retomada por Gramsci (1999) em Os Cadernos do Cárcere nos quais são apresentadas as teses centrais de hegemonia, intelectual orgânico e Moderno Príncipe. No entendimento de Gramsci, a hegemonia consiste no movimento articulado - o bloco histórico formado pela estrutura e a superestrutura - que organiza e dinamiza o "Estado ampliado", ou seja, a sociedade civil e a sociedade política na direção e planejamento das disputas políticas. Esse conceito exerce um duplo sentido na concepção gramsciana: denuncia os instrumentos empregados pela hegemonia burguesa; e estabelece uma estratégia eficaz para o triunfo das classes trabalhadoras, supostamente representadas pelo partido.

Na visão gramsciana (1999), a sociedade é um organismo complexo e relacional, que não pode ser totalmente explicada em termos de um determinismo econômico mecanicista, como propugnado pelo marxismo ortodoxo. Por isso ele não negava a mais-valia, a luta de classes, o materialismo histórico, o fim do "estado burguês", mas tentava mostrar, a partir do pensamento de Marx, o impacto dos fatores morais, culturais e ideológicos nos processos sociais. A hegemonia, em suma, não se concretiza apenas com a posse dos meios de produção; a luta também se dá no campo ideológico.

$\mathrm{Na}$ perspectiva gramsciana, portanto, os argumentos sobre a hegemonia indicam, de fato, as coordenadas para a conquista do poder. No campo da educação, por exemplo, a hegemonia pode servir de espaço para a conscientização e formação de elites técnicas e dirigentes no interior da categoria de trabalhadores educacionais. O intelectual, para Gramsci, tem uma função gerencial e de difusão ideológica no organismo, seja no aparelho burocrático do partido, seja nas instituições e centros de irradiações de cultura e ideologia. Nesse sentido, todo ser humano é potencialmente um intelectual, não por erudição e instrução, mas porque é capaz de assumir uma posição organizadora na sociedade.

Na visão de Gramsci

O Estado é todo o conjunto de atividades teóricas e práticas com as quais a classe dirigente justifica e mantém não somente a sua dominação, mas também consegue obter o consenso ativo dos governados. (GRAMSCI, 1976, p. 87). 
E afirma ainda que:

[...] as relações de organizações internas e internacionais do Estado tornam-se mais complexas e maciças, e a fórmula jacobino-revolucionária da "revolução permanente" é elaborada e superada na ciência política pela forma de "hegemonia civil” (GRAMSCI, 1976, p 92).

Nessa perspectiva marxista de Estado, a promulgação da CF 1988 deu-se graças às condições materiais e ideológicas existentes. O Estado brasileiro "[...] responde também aos movimentos do conjunto da sociedade e das outras clases sociais [..] vinculados aos interesses da burguesia", lembra Ianni (1996). Assim criou-se um novo cenário político e social propício à construção do chamado Estado de direito democrático social, inclusive, abrindo-se para a sociedade brasileira a possibilidade de eleições diretas para o chefe do executivo nacional, após vinte anos de regime de ditadura militar no país, período marcado pelas limitações dos direitos políticos e cerceamento dos direitos sociais.

A promulgação da CF de 1988, de fato, "denuncia os instrumentos empregados pela hegemonia burguesa, e estabelece uma estratégia de luta das classes trabalhadoras [..], no entendimento de Gramsci (1999). Deu-se um complexo realinhamento jurídico-institucional das relações democráticas entre o Estado e sociedade civil, preservando-se ainda ranços autoritários do passado e mantendo-se inalterada a estrutura da ordem capitalista vigente no país, mas abrindo-se novos espaços de participação da sociedade civil na construção do Estado. Fernandes enfatiza que no texto final da Carta Magna de 1988:

Duas coisas essenciais ficaram patentes. Primeiro, a Constituição extingue, de
imediato ou através de leis complementares, a ordem ilegal montada pela ditadura e
mantida pela 'Nova República' que se serviu abundantemente de leis e decretos-leis
discricionários e prolongou o arbítrio do regime anterior. Segundo, essa Constituição
colcha-de-retalhos contém dentro de si tanto a reprodução do passado quanto a
reconstrução da sociedade civil, concebida para ser mais aberta e democrática. É o
ponto de partida para que se forje uma nova ordem social, na qual os mais iguais
perderão o monopólio do poder e os humildes poderão ganhar maior consciência
social e maior envergadura no uso político da luta de classes. [...] a Constituição não é
um fim em si e por si. Ela é um meio. Os debaixo devem fazer como os de cima:
resolver na luta direta como utilizar produtivamente os dispositivos da carta
constitucional e promover a sua substituição assim que se comprove que ela só serve
para a lata de lixo da História.. (FERNANDES, 1989, p. 349)

Evidencia-se que a Carta Magna preserva ainda ranços autoritários da ditadura militar e mantém a estrutura do sistema capitalista no país, mas cria possibilidades de um novo tempo político, marcado por relações democráticas entre Estado e sociedade civil. Fernandes é enfático ao considerar a chamada "transição" do regime de ditadura militar para o Estado de 
direito democrático social como marco na história das torpezas políticas no país, assim configurada:

Políticos serviçais da ditadura atravessaram o Riacho Fundo, para continuarem no poder; estrategicamente, a vanguarda ditadorial recuou para o segundo plano, mantendo-se porém como o garante do sistema democrático de poder e de “transição democrática". Dela resultou a chamada "Nova República"e um governo inviável. Este não se tornou inviável por cusa da morte do Presidente Tancredo Neves, que manobrou como o comandante do Titanic. Ele nasceu, cresceu e manteve-se ingovernável porque possuía três centros de poder, em atrito permanente entre si e centrífugos com referência ao conjunto institucional chamado "Nova República”. (FERNANDES, 1989, p. 146)

$\mathrm{Na}$ perspectiva de Fernandes, o melhor teria sido conduzir a luta política contra a ditadura até prostrá-la e derrotá-la por inteiro. Mas as elites econômicas, sociais, políticas e militares das classes dominantes preferiram o contrário:

\begin{abstract}
Naquele momento, tanto as nações capitalistas e sua superpotência propunham em primeiro plano a estabilidade política (democracia para quê?, em um país-chave da periferia?) quanto os estratos dominantes das classes possuidores não queriam correr o risco de um processo de transformação política rápido demais, do qual acabariam perdendo o controle. Assim, a ordem ilegal continua em vigor o que ela representa como obstáculo à construção de uma sociedade civil civilizada e de um estado capitalista democrático. (FERNANDES, 1989, p. 146)
\end{abstract}

Mas, apesar das torpezas apontadas por Fernandes, por outro lado, Vieira afiram que afirma que:

Em nenhum momento a política social encontrou tamanho acolhimento em Constituição brasileira como acontece na Constituição de 1988, Capítulo I1 do Titulo 11, Dos Direitos e Garantias Fundamentais nos campos da educação pré-escolar, fundamental, nacional, ambienta1, da saúde, da assistência, da previdência social, do trabalho, do lazer, da maternidade, da infância e da segurança, definindo especificamente direitos dos trabalhadores urbanos e rurais, de associação profissional ou sindical, de greve, de participação de trabalhadores e empregadores em colegiados dos órgãos públicos e de atuação de representante dos trabalhadores no entendimento direto com empregadores.(VIEIRA, 1996, p. 10)

Em verdade, embora a CF de 1988 ainda preserve ranços do regime passado e sem alterar ideologia da ordem capitalista que continua vigente no país em 2015, pode-se dizer que foi uma conquista da sociedade civil, propiciando um novo realinhamento jurídicoinstitucional da gestão do Estado, alicerçado em fundamentos democráticos.

Dentro desse novo realinhamento jurídico-institucional da gestão do Estado, situamse as configurações da política educacional brasileira pós CF de 1988, a partir da década de 90, face às demandas implementadas no estágio em que se encontrava a reestruturação produtiva do capital. A educação, para Hofling (2001), como política social, assumiu 
diferentes configurações em diferentes sociedades e Estados. Em linhas gerais, como ocorreram essas configurações no contexto das particularidades desse momento histórico, que compreende um determinado projeto político de Estado e sociedade?

Conforme análise de Saes (1998) sobre a teoria do Estado burguês, em todas as sociedades marcadas pela divisão de classes (escravista, feudal e capitalista), o Estado caracteriza-se como a organização especializada em neutralizar a luta entre as classes antagônicas e garantir a preservação das relações de dominação e exploração. Para cumprir tal função, o Estado cria condições ideológicas que inibe qualquer ação que possa resultar em luta contra os proprietários dos meios de produção. A ideologia dominante estabelece consensos, que permitem “[...] assegurar a inserção prática dos agentes na estrutura social, via manutenção - a coesão - desta estrutura, o que quer dizer, antes de mais nada, a exploração e a dominação de classe" (POULANTZAS, 1971, p. 33).

Atrelado às condições ideológicas, o Estado mantém sua função econômica e política, no sentido de garantir a reprodução capitalista. No entendimento de Netto a função do Estado passa por um redimensionamento na crise do capitalismo contemporâneo:

o último terço do século XX assinala o exaurimento das possibilidades civilizatórias da ordem do capital. [...] a ordem tardia do capital não tem mais condições de propiciar quaisquer alternativas progressistas para a massa dos trabalhadores e para a humanidade. O fundamento último desta verdadeira mutação na dinâmica do capital reside no que o Prof. Mészáros vem caracterizando como a especificidade do tardocapitalismo: a produção destrutiva, que presentifica a crise estrutural do capital. Todos os fenômenos e processos em curso na ordem do capital nos últimos vinte e cinco anos, através de complexas redes e sistemas de mediação - que exigem investigações determinadas e concretas para a sua identificação e a compreensão da sua complicada articulação -, estão vinculados a esta transformação substantiva. Eles afetam a totalidade das instâncias constitutivas da vida social em escala planetária. (NETTO, 2012, p. 202).

Afirma Netto que na atualidade:

Também o Estado burguês, mantendo o seu caráter de classe, experimenta um considerável redimensionamento. A mudança mais imediata é a diminuição da sua ação reguladora, especialmente o encolhimento de suas "funções legitimadoras" [...] e tem-se o corte nos direitos sociais - [...] a estratégia do grande capital de "redução do Estado", num processo de "ajuste" que visa a diminuir o ônus do capital no esquema geral de reprodução da força de trabalho e das condições gerais da reprodução capitalista. (NETTO, 2012, p. 202).

Em sintonia com as afirmações de Netto, Neves salienta que: 
O delineamento desse processo conferiu, a um pequeno grupo de países, a hegemonia do capital financeiro, deixando à margem da globalização periférica, a maioria dos países pobres. A implantação de medidas macroeconômicas e a exploração dos países capitalistas periféricos deixaram claras as intenções dos representantes do grande capital mundial na exploração da classe trabalhadora, estabelecendo um discurso que incorporou suas demandas via estratégias focalizadas e restritivas. (NEVES, 2005, 202)

Evidencia-se nessas argumentações que para legitimar a nova ordem capitalista, fez-se necessária a reconfiguração do Estado, mediante às demandas implementadas no estágio em que se encontrava a reestruturação produtiva do capital. Nessa reconfiguração, considerou-se o chamado Estado de bem-estar social ineficiente, ineficaz e pouco produtivo, para assim relevar o Estado neoliberal e as estratégias de ajustes estruturais que legitimam o consenso em torno dos padrões das relações vigentes estabelecidas pelas agências financeiras multilaterais.

Nas palavras de Toussaint,

A política de ajustes estruturais foi implantada nos países periféricos, especialmente, a partir da década de 1990. Com a explosão da crise da dívida externa, muitos países, para reverter os efeitos da crise, recorreram a empréstimos das agências financeiras multilaterais - Banco Mundial (BM) e Fundo Monetário Internacional (FMI) e, como contrapartida, tiveram que aderir às reformas estruturais de cunho neoliberal. [...] estes empréstimos de caráter político são concedidos pelas instituições com a condição de que o governo nacional adote um programa de estabilização econômica e de reformas de estruturas econômicas, de acordo com as exigências do emprestador. (TOUSSAINT, 2002, p. 200)

Para se acomodar os inúmeros ajustes provocados pela nova ordem social gestada sob o comando do capital financeiro, novas relações foram estabelecidas entre Estado e sociedade civil. Na análise de Neves,

Desde a década de 1990, o Banco Mundial vem propalando que são necessárias novas funções do Estado para conduzir um mundo globalizado em transformação. Nesse processo, as agências internacionais definiram estratégias de ação com o intuito de orientar tanto a política econômica, quanto a conformação social dos países em desenvolvimento. (NEVES, 2002, p. 90).

Deve-se assinalar, porém, que as políticas neoliberais implementadas pelos Estados capitalistas não podem ser vistas como mero transplante da doutrina do neoliberalismo econômico aos países periféricos, visto que cada país possui suas peculiaridades, diferenciando-se nos aspectos econômicos, sociais, políticos e culturais. Sobre isso, Saes assinala que: 
Tais políticas não podem concretizar incondicionalmente os princípios econômicos liberais, já que elas não são implementadas num espaço social vazio, destituído de qualquer historicidade, é assim em sociedades capitalistas históricas, nas quais a política estatal repercute, há décadas, a influência de outros princípios econômicos. (SAES, 2001, p. 81).

No Brasil, a implantação da política estatal neoliberal teve seu auge nos anos 1990, no governo do Presidente Fernando Henrique Cardoso, que promoveu uma ampla reforma do Estado com medidas para reverter os efeitos da crise fiscal e fortalecer a economia do país para torná-lo competitivo no mercado internacional. Na análise de Silva, ao se reportar à reforma da educação no governo de Fernado Henrique Cardoso,

O Banco Mundial chega ao interior das escolas públicas por meio de programas, projetos e planos elaborados por seus técnicos e conselheiros endossados pelo Ministério da Educação, separando o pensar e o fazer. A comunidade escolar é apenas informada sobre os programas, projetos e planos, recebendo orientações necessárias ao preenchimento de formulários e prestação de contas. [...]. (SILVA, 2003, p. 299)

Para viabilizar medidas que consubstanciaram as reformas estruturais preconizadas pelo Banco Mundial, o Governo Fernado Henrique criou um ministério próprio para isso, o Ministério da Administração e Reforma do Estado (MARE). Esse Ministério apresentou, em 1995, o Plano Diretor do Aparelho do Estado que foi implantado para ampliar a ação do Estado e, consequentemente, sua capacidade de implementar políticas públicas de forma eficiente e eficaz. Conforme expressa o documento,

\footnotetext{
A reforma do Estado deve ser entendida dentro do contexto da redefinição do papel do Estado, que deixa de ser o responsável direto pelo desenvolvimento econômico e social pela vida da produção de bens e serviços, para fortalecer-se na função de promotor e regulador desse desenvolvimento (BRASIL, 1995, p. 12)
}

A reforma do Estado implicou mudanças em sua aparelhagem a fim de tornar a adminsitração pública mais eficiente e eficaz. Para isso, “[...] o Estado reduz seu papel de executor ou prestador direto de serviços, mantendo-se, entretanto, no papel de regulador e provedor ou promotor destes, principalmente dos serviços sociais com o educação e saúde" (BRASIL, 1995, p. 13).

Ao relevar as proposições neoliberais, o documento advoga um Estado capitalista para as políticas públicas, pois não deixa de apontar a necessidade de redução do aparelho do Estado por meio de estratégias que visam à privatização, desregulamentação e terceirização. Neste sentido, a proposta formulada no documento Plano implementado pelo MARE 
consistiu em descentralizar, para o setor público não-estatal, os serviços considerados nãoexclusivos do Estado, tais como: saúde, educação, cultura e pesquisa científica. Para tanto, adotaram-se programas de publicização, que incentivaram o envolvimento ativo da sociedade na responsabilização dos serviços.

$\mathrm{Na}$ abordagem de Soares,

Ao Estado, coube manter programas compensatórios destinados à população mais vulnerável, tornando evidente seu caráter classista, ao legitimar um sistema de produção social privado para o atendimento de uma minoria que pôde pagar pelos serviços e um sistema público fragilizado para atender à grande maioria da população. (SOARES, 2003, p. 40).

É nesse contexto de reconfiguração do papel do Estado baseada em preceitos neoliberais para reestruturação da ordem econômica capitalista, que ocorreram as novas configurações da política educacional, atribuindo-se centralidade à educação como elemento privilegiado na concretização dos ajustes necessários e na conformação da ordem societária vigente no país.

Como parte do movimento de reconfiguração das ações implementadas pelo Estado, a política educacional passou a ser alvo de reformas fortemente influenciadas pelas políticas das agências multilaterais de financiamento, em especial pelo BM, considerado o principal órgão financiador das políticas sociais para os países em desenvolvimento ou emergentes.

As reformas no campo educacional penderam para a adoção de medidas que priorizaram a retração dos investimentos nos sistemas públicos e com efeitos compensatórios para tender à qualificação de habilidades necessárias ao trabalho, sendo compatível com os valores que desconsideram o exercício do pensamento crítico.

Sob as orientações das agências internacionais, em especial a do Banco Mundial e da Comissão Econômica para América Latina e Caribe (CEPAL), novas demandas foram lançadas para a política educacional com o propósito de adequá-la aos interesses econômicos regulados pelo ideário neoliberal. As propostas de uma educação básica de qualidade, como instrumento necessário ao desenvolvimento econômico dos países e como forma de assegurar a equidade, transformam-se, assim, em discursos oficiais para estabelecer um consenso geral, bem como na formulação de valores e atuitudes desejáveis para a manutenção e reprodução da ordem econômica vigente. Assim foram definidas novas relações entre o Estado e a sociedade civil para a conformação social, tendo, na educação, instrumento hegemônico de legitimação das relações sociais. 
No documento Prioridades y Estratégias para La Educación essa questão da centralidade da educação fica evidenciada ao destacar que,

\begin{abstract}
A educação, especialmrente a primária e a secundária do primeiro ciclo (educação básica), ajuda a reduzir a pobreza aumentando a produtividade do trabalho dos pobres, reduzindo a fecundidade e melhorando a saúde, e favorece a população de atitudes que necessita para participar plenamente na economia e na sociedade. (BANCO MUNDIAL, 1996, p. 15)
\end{abstract}

Nesse contexto, o MEC passou a elaborar mecanismos legais, expressos em programas e projetos educacionais, com o propósito de implantar uma ampla reforma educacional, envolvendo várias dimensões do sistema de ensino como gestão educacional, financiamento, currículos escolares, legislações, planejamento, avaliação, entre outras. A implementação dessas reformas proporcionou uma nova configuração à política educacional com a introdução de parâmetros economicistas que subsumem o próprio direito à educação.

A partir de 1990, as políticas educacionais brasileiras ajustaram-se às novas exigências postuladas pelo ideário neoliberal, incorporando as orientações políticas das agências multilaterais de financiamento para a construção de consensos em torno da necessidade de refomas educativas. As conferências e seminários realizados pelas agências internacionais reforçam em seus documentos, as estratégias de reforma e influenciaram a definição de diretrizes para a implantação das políticas educacionais no país.

Pode-se dizer que as novas configurações da política educacional brasileira se forjaram num movimento de contradições e de dissensos vinculados ao estágio em que se encontrava a reestruuturação produtiva do capital, tendo, nas refomas educacionais, as estratégias necessárias para manutenção e reprodução do status quo.

Nesse cenário, de contradições, as reformas educacionais estavam asseguradas na $\mathrm{CF}$ de 1988 que, mesmo conservando os ranções autoritários do regime político anterior, possibilitou a abertura de novos temas educacionais, entre eles, a questão da valorização dos profissionais da educação básica, na Carta magna pela Assembléia Nacional Constituinte $(\mathrm{ACN})$, em decorrência dos debates e embates que vieram ocorrendo já durante a ditadura militar de 64. A CF de 1988 passou a ser o parâmetro à criação da legislação infraconstitucional pertinente à valorização dos profissionais da educação básica, a partir da década de 1990. 


\subsection{A inserção da valorização dos profissionais da educação na Constituição Federal de 1988 e em legislação infraconstitucional}

Mesmo durante o regime militar de 1964 já havia uma fermentação política em favor da redemocratização da educação pública e da valorização dos profissionais nesse campo. A Carta de Goiânia de 1987 e a Carta Magna de 1988 expressaram os resultados dos debates e embates políticos que já vinham ocorrendo no campo da educação anteriormente. As lutas pelas reformas de ensino, especialmente pela reforma universitária e o desenvolvimento de entidades de professores, como o Sindicato Nacional dos Docentes das Instituições de Ensino Superior (ANDES) e a Confederação dos Professores do Brasil (CPB); de funcionários, como a Federação de Sindicatos de Trabalhadores em Educação das Universidades Brasileiras (FASUBRA) e de estudantes como a União Nacional dos Estudantes (UNE) e a União Brasileira de Estudantes Secundaristas (UBES), que emergiram contra o regime ditatorial, resultaram num conjunto de forças e numa contribuição pedagógica levada à Assembléia Nacional Constituinte, colocando em discussão a questão do ensino público no âmbito do Estado democrático em construção, na perspectiva de rompimento com os ranços do passado autoritário e instauração de novas configurações. Foi muito importante o apoio dessas e outras instituições civis organizadas para a garantia dos artigos 205 e 206 da CF de 1988, bem como para a consolidação de outras questões relativas à educação pública (FERNANDES, 1989, p. 120).

A CF de 1988 e a Carta de Goiânia de 1987 representaram um marco histórico na perspectiva de mudança do quadro caótico da educação pública no país. A educação no Brasil sempre se caracterizou pela fragilidade ou inexistência de políticas públicas, descompromisso do Estado, elitização e privatização, escassez de oferta, parcos recursos e processos tardios em comparação com outros países, inclusive da América Latina. No tocante à valorização do trabalho docente, não obstante os avanços no campo legal, sempre careceu de estruturação da carreira, formação qualificada, reconhecimento, valorização e salários dignos. Com a promulgação da Carta Magna de 1988, a sociedade brasileira defrontou-se com esse cenário, mas abriram-se novas perspectivas de mudança da educação pública no país. (CAMARGO et al., 2009).

A Carta Magna de 1988 expressou a garantia do direito à educação, alicerçada nos princípios de universalidade, eqüidade e qualidade, conforme disposto em seu artigo 205, refletindo diretamente sobre o artigo 206, inciso V, que dispõe sobre a valorização dos 
profissionais do ensino, por meio da implemementação de planos de carreira e da instituição do piso salarial profissional.

O Art. 205 do texto constitucional assim dispõe:

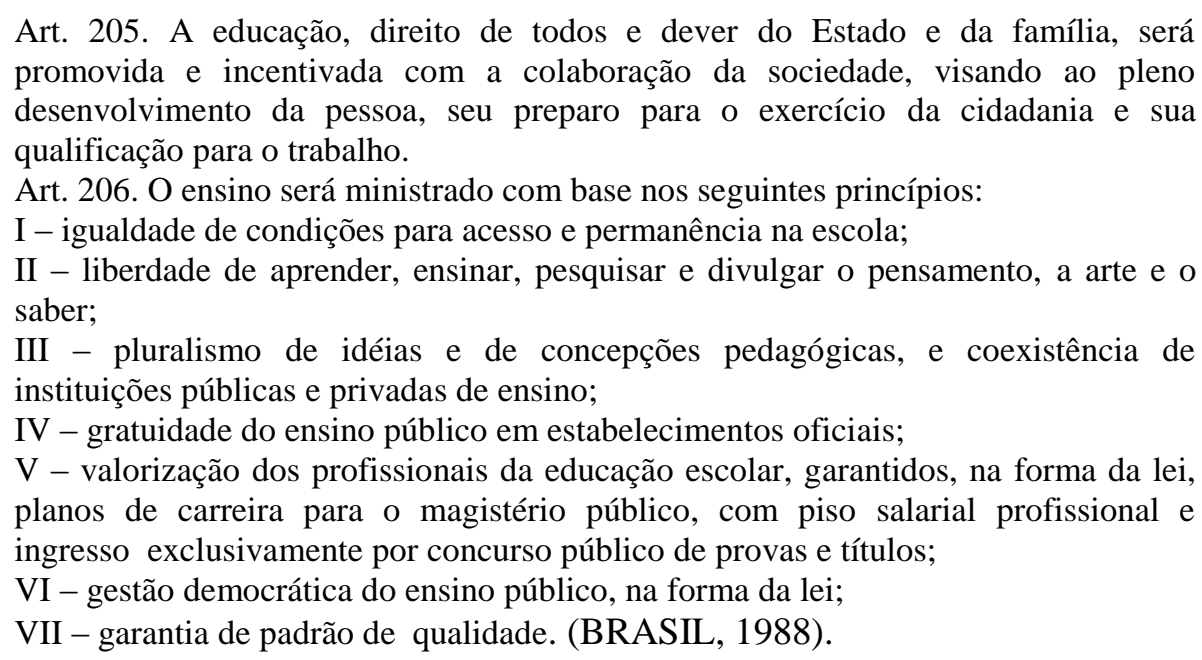

O texto constitucional (BRASIL, 1988), além de increver a educação como direito universal e subjetivo, assegura no inciso V do art. 206, a valorização dos profissionais da educação escolar, ressaltando pelo menos três elementos básicos: planos de carreira, piso salarial profissional e ingresso exclusivamente por concurso público de provas e títulos. $\mathrm{O}$ plano de carreira expressa a ideia de progressão e estabilidade no trabalho; o piso salarial tem o sentido de garantia de valorização salarial dos membros do magistério público; e o ingresso por concurso consiste na necessidade de uma titulação acadêmica de qualidade, comprovada pela superação das provas de ingresso.

Com base na CF de 1988, nova legislação específica para a educação, que trata da valorização dos profissionais da educação básica, foi e continua sendo elaborada, com destaque para a Lei $n^{\circ}$ 9.394/96, Lei de Diretrizes de Bases da Educação Nacional (LDB); a Lei $\mathrm{n}^{\circ}$ 9.424/96, que instituiu o Fundo de Manutenção e Desenvolvimento do Ensino Fundamental e de Valorização do Magistério (Fundef); e a Lei 11.494/07, que instituiu o Fundo de Manutenção e Desenvolvimento da Educação Básica e de Valorização dos Profissionais da Educação (Fundeb). Este movimento político e jurídico mostra como a ideia de valorização dos profissionais da educação básica veio evoluindo até chegar à sua consolidação por meio da promulgação da Lei 11.738/2008, que institui o PSPN.

Sem pretender minimizar a relevância da legislação existente sobre a educação no país, leva-se em conta o Título VI, Artigo 67, da LDB (BRASIL, 1996), que reafirma o princípio constitucional e traz elementos da valorização dos profissionais da educação, dentre 
os quais os seguintes direitos: ingresso por concurso, tempo remunerado para formação, estudos e planejamento, piso salarial, progressão funcional e condições de trabalho. O Art. 67 da LDB assim dispõe:

\footnotetext{
I. Ingresso excluviamente por concurso público de provas e títulos;

II.Aperfeiçoamento profissional continuado, inclusive com licenciamento periódico remunerado para este fim;

III. Piso salarial profissional;

IV. Progressão funcional baseada na titulação ou habilitação, e na avaliação do desempenho;

V. Período reservado a estudos, planejamento e avaliação, incluído na carga de trabalho;

VI. Condições adequadas de trabalho. (BRASIL, 1996).
}

Para chegar a esses termos, muitos debates e embates ocorreram no processo de elaboração da LDB. Conforme Monlevade (2000), a tramitação da LDB de 1996 se iniciou por iniciativa de deputados e senadores desde dezembro de 1988, com a apresentação do primeiro Projeto de Lei (PL), de autoria do deputado Octávio Elyseo (PMDB-MG). Seu texto tinha sido fruto da Carta de Goiânia de 1987 e das discussões no Sindicato Nacional dos Docentes das Instituições de Ensino Superior (Andes), tendo como proposta a valorização dos educadores, nos seguintes termos:

\footnotetext{
Art. 55. O provimento dos cargos iniciais e finais da carreira do magistério nas instituições oficiais será feito mediante concurso público de provas e títulos.

Art. 57. O Ministério da Educação, por proposta do Conselho Federal de Educação, encaminhará projeto de lei estabelecendo a carreira nacional dos professores e especialistas em Educação. (BRASIL, 1987).
}

Efetivamente, a elaboração LDB teve início com a constituição de um grupo de trabalho, formado pelos deputados Ubiratan Aguiar (PMDB-CE), presidente da Comissão de Educação, Cultura e Desporto da Câmara Federal de Deputados à época, o deputado Florestan Fernandes (PT-SP) que assumiu o papel de coordenador e Jorge Hage (PSDB-BA) que foi o relator do projeto (SAVIANI, 1997, p. 57). Como pontua Monlevade (2000), outros projetos apresentados foram apensados ao do deputado Octávio Elyseo e tratados pelo relator num processo amplo e demorado de consultas à entidades educacionais e especialistas de todas as tendências ideológicas e interesses políticos e econômicos. O setor educacional organizado, mobilizado desde a Assembléia Nacional Constituinte para elaboração da CF de 1988, por meio do Fórum em Defesa da Escola Pública, manteve-se atuante durante as discussões até a aprovação da LDB.

Após um longo período de tramitação e muitos debates e embates, em 20 de dezembro de 1996, a Lei $n^{\circ} 9.394$ foi sancionada pelo presidente Fernando Henrique Cardoso, 
estabelecendo as Diretrizes e Bases da Educação Nacional, um texto híbrido, com forte ascendência do Ministério da Educação, materializando, desse modo, a ideia de valorização dos profissionais da educação no art. 67 da LDB.

O art. 67 da LDB remete aos sistemas de ensino a questão da valorização dos profissionais da educação básica, ressaltando que cada ente federado pode estabelecer o seu piso salarial, o que equivale a dizer que, por tal dispositivo, torna o piso salarial uma questão mais complexa, impedindo o estabelecimento de uma referência nacional e possibilitando a estipulação de diversos valores nos estados e municípios. "Quantos patrões, tantos pisos" (MONLEVADE, 2000, p. 150).

Outra Lei que dispõe sobre o piso salarial é a de $n^{\circ} .9 .424$, no governo do Presidente Fernando Henrique Cardoso, que instituiu o Fundo de Manutenção e Desenvolvimento do Ensino Fundamental e Valorização do Magistério (Fundef).

A valorização do magistério como objetivo do Fundef, regulamentado pela Lei $n^{\circ} 9.424$ (BRASIL, 1996), passou a ser garantida apenas nos seguintes termos:

\footnotetext{
Art. $7^{\circ}$. Os recursos do Fundo, incluída a complementação da União, quando for o caso, serão utilizados pelos Estados, Distrito Federal e os Municípios, assegurados, pelo menos, $60 \%$ (sessenta por cento) para a remuneração dos profissionais do Magistério, em efetivo exercício de suas atividades no ensino fundamental público. $[\ldots]$

Art. $9^{\circ}$. Os Estados, o Distrito Federal e os Municípios deverão, no prazo de seis meses da vigência desta Lei, dispor de novo Plano de Carreira e Remuneração do Magistério, de modo a assegurar:

I - a remuneração condigna dos professores do ensino fundamental público, em efetivo exercício no magistério.

[...]

Art. 10. Os Estados, o Distrito Federal e os Municípios deverão comprovar:

[...]

II - apresentação de Plano de Carreira e Remuneração do Magistério, de acordo com as diretrizes emanadas do Conselho Nacional de Educação, no prazo referido no artigo anterior. (BRASIL, 1996)
}

Predominantemente caracterizado como um fundo equalizador de recursos financeiros no âmbito de cada Estado e tendo como foco exclusivo o atendimento ao ensino fundamental, o Fundef estabeleceu o mínimo de $60 \%$ para ser aplicado na remuneração dos professores desse nível de ensino, assim como o prazo para a implantação dos planos de carreira. Mas deixou de apresentar especificidades sobre como deveria ser pautada a carreira do magistério, e também não absorveu a ideia de Piso Salarial Profissional Nacional, remetendo ao Conselho Nacional de Educação a tarefa de normatizar os pressupostos dessa questão.

O Manual de Orientação do MEC sobre o Fundef é enfático ao afirmar que:

As normas federais não determinam, nacionalmente, o valor da remuneração do magistério, nem mesmo o piso salarial profissional. O que está fixado é o montante 
de recursos a ser destinado ao pagamento dos profissionais do magistério: mínimo de $60 \%$ do Fundef, exclusivo para o Ensino Fundamental. A remuneração dos profissionais da educação, no que se refere tanto ao piso (menor salário), quanto ao teto (maior salário) do magistério, será definido em normas legais de cada nível de governo, nos respectivos Planos de Carreira e Remuneração do Magistério. O valor do investimento mínimo nacional, fixado por aluno/ano, não é o piso, nem teto salarial nacional. (BRASIL, 2004, p. 22)

É bem verdade que o Fundef reservou no mínimo $60 \%$ da sua receita para salários de professores e também dispôs sobre a criação de Conselhos de Acompanhamento e Controle Social (CACs). Mas a folha de pagamento de muitos Estados para salários de profissionais da educação já mostrava em 1998, que os salários custavam mais de 60\% estabelecidos na Lei. Essa situação levou vários entes federados a gastarem até $100 \%$ dos seus recursos para Manutenção Desenvolvimento do Ensino (MDE) somente com a folha de pagamento de salários, porque diversos Estados passaram a transferir recursos para o Fundef. (BRASIL, 2004, p. 22 )

A Lei do Fundef (BRASIL, 2004) também dispôs que os recursos se destinariam aos salários para os professores efetivamente em exercício no magistério do ensino fundamental. Tal disposição levou os gestores educacionais nos estados e municípios a resolverem essa questão. Então, os salários de professores da educação infantil e do ensino médio, que não eram incluídos no Fundef, mesmo assim, eram pagos pelo Fundo.

Peroni (2003) aponta que no governo neoliberal do Presidente Fernando Henrique Cardoso, paulatinamente, foram sendo substituídas as conquistas democráticas anteriores por políticas de restrições e constrangimentos para a classe trabalhadora. Em decorrência disso, para os profissionais da educação básica, a possibilidade de construção do Piso Salarial Profissional Nacional ficou muito distante, na medida em que se implantou o valor do custo/aluno/ano mínimo materializado na reforma da política educacional para o financiamento da educação básica. As duas gestões do Presidente Fernando Henrique Cardoso (1995-2002) caracterizaram-se pelo estímulo do Estado à privatização, à municipalização da educação e pela redução de direitos dos trabalhadores por pressão dos organismos multilaterais. A influência de tais organismos pode ser constatada em documentos tornados públicos pelo Congresso Nacional, em 1998, contendo a Estratégia de Assistência ao País, que o Banco Interamericano de Desenvolvimento (BID) e Banco Mundial (BM) adotaram para monitorar os empréstimos feitos ao governo.

A prioridade número um parecia ser mesmo o pagamento da dívida com os credores internacionais. Evidentemente, nessa conjuntura, a discussão sobre o Piso Salarial Profissional Nacional não tinha as mínimas condições de prosperar.

Neves (2005) lembra que o governo do Presidente Fernando Henrique Cardoso, entre 1995-2002, aderiu ao ajuste estrutural provocado pela onda neoliberalizante, promoveu as 
formas de intervenção do Estado na economia, por meio das privatizações e da focalização das políticas sociais. Já Abicalil (2008) destaca queno tocante à instituição do Piso Salarial Profissional Nacional, a questão não foi contemplada na Lei do Fundef, da mesma forma que foi apresentada sem objetividade nas disposições da LDB ao aparecer sem a adjetivação nacional.

A continuidade do processo democrático brasileiro pela via eleitoral colocou em 2002, na chefia do executivo federal, o Presidente Luiz Inácio Lula da Silva, do Partido dos Trabalhadores (PT), em uma ampla aliança política com a burguesia industrial. Embora em seu programa de governo apresentasse princípios e diretrizes alternativos ao ideário neoliberal, sua administração revelou as profundas contradições que engendram o modo de produção capitalista.

Foi no segundo mandato do Presidente Luiz Inácio Lula da Silva que a Lei 11.494/07, que institui o Fundo de Manutenção e Desenvolvimento da Educação Básica e de Valorização dos Profissionais da Educação (Fundeb) foi sancionada e vinculada diretamente à Lei $11.738 / 2008$.

Nessa nova conjuntura, o movimento docente intensificou suas lutas com relação à defesa de melhores condições de trabalho e salários. Prova disso foi o número crescente de greves registradas nos diversos Estados da federação durante os últimos anos da primeira década deste século: os professores do estado de São Paulo fizeram greves em junho de 2000, 2007, 2008, 2009 e 2010; em julho de 2008 deflagraram greve os professores do estado de Minas Gerais e da Bahia; de igual modo, em 2009, entraram em greve os docentes dos Estados de Sergipe, Maranhão, Rio de Janeiro, Distrito Federal, Rio Grande do Norte. Essa mobilização teve seu ponto alto quando se declarou 24 de abril de 2007 como um dia de luta dos professores de todo o país, em defesa da implantação integral da Lei do PSPN, movimento que teve repercussão nacional. (Arquivos da Divape/Sase/MEC, 2011).

Ao mesmo tempo, as organizações sindicais, científicas e acadêmicas docentes tentaram intervir e participar do novo processo político instalado no país, no período 2002/2009, particularmente no debate sobre o Fundeb, e estiveram presentes no Congresso Nacional na discussão sobre o financiamento da educação básica e a criação da Lei $11.738 / 2008$.

O Fundeb foi aprovado em dezembro 2006. A Emenda Constitucional (EC) $\mathrm{n}^{\mathrm{o}} 53$ (BRASIL, 2006) que o criou, estabeleceu um prazo de 14 anos a partir da sua promulgação, como período de duração e ainda, a complementação da União, assim descrito: 
A obrigatoriedade da complementação de recursos pelas Unidades Federadas poderá sofrer sanção disciplinar, conforme o estabelecido na citada Emenda, a saber: 'o não cumprimento do disposto nos incios V e VII do caput do artigo $2^{\circ}$ importará crime de responsabilidade da autoridade competente'. Também o inciso XII estabelece que a proporção não inferior a $60 \%$ de cada Fundo deverá ser destinada ao pagamento dos profissionais do magistério da educação básica em efetivo exercício. (FRANÇA, 2007, p. 190).

O art. 22 da Lei 11.494 (BRASIL, 2007) que regulamentou o Fundeb também garante a remuneração dos profissionais docentes, nestes termos: pelo menos 60\% (sessenta por cento) dos recursos anuais totais dos Fundos serão destinados ao pagamento da remuneração dos profssionais do magistério da educação básica em efetivo exercício na rede pública.

A subvinculação de parte dos recursos (60\%) do Fundeb para a remuneração dos profissionais do magistério apresenta-se como elemento central no processo de construção de uma política de valorização salarial do magistério, porém não o suficiente. Cabe, portanto, aos gestores estaduais e municipais a aplicação de outros recursos em educação, inclusive parte dos $25 \%$ conforme reza a CF de 1988 .

Nesse sentido, pontua-se que a Lei 11.494 especificou as responsabilidades dos Estados e municípios para com a política de valorização dos profissionais da educação nos seguintes termos:

Art. 40. Os Estados, Distrito Federal e os Municipios deverão implantar Planos de Carreira e remuneração dos profissionais da educação básica, de modo a assegurar: I - a remuneração condigna dos profissionais na educação básica da rede pública; II - integração entre o trabalho individual e a proposta pedagógica da escola; III - a melhoria da qualidade do ensino e da aprendizagem.

Parágrafo único. Os Planos de carreira deverão contemplar a capacitação profissional especialmente voltada à formação continuada, om vistas à melhaoria da qualidade do ensino. (BRASIL, 2007)

Desse modo, os únicos recursos destinados às redes estaduais e municipais de educação são aqueles referentes à complementação federal, considerados irrisórios no Fundef (menos de $1 \%$ da receita nacional em 2006) e bem pequenos no Fundeb (menos de 5\% da receita nacional em 2007, e 10\% do total a partir de 2010). Assim, mesmo com a aprovação do Fundeb, a questão da valorização dos professores continuou sendo um problema central na educação básica.

Além disso, a Lei que regulamentou o Fundeb (BRASIL, 2007), em seu art. 41, definiu que o poder público deveria fixar, em lei específica, até 31 de agosto de 2007, o Piso Salarial Profissional Nacional para os profissionais do magistério público da educação básica. E em seu artigo $2^{\circ}$ afirma que os Fundos destinam-se à manutenção e ao desenvolvimento da 
educação básica pública e à valorização dos trabalhadores em educação, incluindo sua condigna remuneração.

Essas mesmas questões foram ratificadas nas discussões da Conferência Nacional de Educação (Conae) de 2010, cujo documento base dedicou um capítulo ao tema: Eixo IV Formação e Valorização dos Profissionais da Educação. O segundo dispõe a seguinte referência:

\begin{abstract}
Mas, possivelmente, em nenhum outro momento histórico tenha merecido tamanha ênfase, por parte de diferentes agentes públicos e privados, instituições, organismos nacionais, internacionais e multilaterais, como nas últimas décadas, reconhecendo o protagonismo dos/das profissionais da educação no sistema educacional. (BRASIL, 2010, p. 77).
\end{abstract}

A Conae de 2010, assim como a Conferência Nacional de Educação de Base (Coneb) de 2008, tiveram um papel importante na mobilização dos profissionais da educação para dar suporte à instituição do PSPN. A Conae de 2010 foi um momento fundamental no processo de elaboração das políticas educacionais, articulando a participação da sociedade civil organizada, autoridades e gestores educacionais, entidades representativas dos profissionais da educação e dos estudantes, entidades sindicais e populares e representativas de pais, mães ou responsáveis de estudantes. Essa Conferência deliberou e consolidou, no seu documento final, diretrizes e metas voltadas para o tema Construindo o Sistema Nacional Articulado de Educação: o Plano Nacional de Educação - PNE, diretrizes e estratégias de ação. (BRASIL, 2012).

A Coneb de 2008 estruturou-se a partir de atividades locais e regionais, conferências municipais, intermunicipais, estaduais, culminando com a Conae de 2010. A Coneb de 2008 discutiu, deliberou e consolidou propostas para estruturação mais igualitárias da educação nacional. E a Conae de 2010, concretizada por meio de uma ampla mobilização desde as escolas e instituições educacionais, passando por atividades locais e conferências municipais, intermunicipais e estaduais, constituiu-se em um espaço político de discussão da educação brasileira, definindo caminhos para a construção de um projeto nacional de educação e de uma política de Estado para a Educação no país.

Nesse contexto de mobilização dos profissionais da educação, a CNTE já havia elaborado uma proposta de piso salarial profissional nacional em 2006, que apresentou na Coneb de 2008, após a instituição do PSPN em 2008, a reforço na Conae de 2010. Tal proposta foi anteriormente apresentada ao Ministério da Educação, em 2007; ao Conselho dos Secretários Estaduais de Educação (CONSED); ao Ministério do Trabalho e Emprego (MTE) e, também, encaminhou um Projeto de Lei de Piso Salarial Profissional Nacional ao 
Congresso Nacional. O Poder Executivo também apresentou, no Congresso Nacional, um Projeto de Lei, em 02 de abril de 2007, que fixava um piso salarial profissional nacional para o magistério, sem, contudo, ter dialogado com os trabalhadores em educação.

Nessa conjuntura, a CNTE manifestou-se contra a forma de encaminhamento da proposta do Poder Executivo e Congresso nacional e convocou os trabalhadores em educação e a sociedade brasileira como um todo, para, no dia 24 de abril de 2007, realizarem um dia de Marcha e de Paralisação Nacional pela Educação, no intuito de repudiar a iniciativa do Poder Excutivo e pressionar o Congresso Nacional na aprovação das emendas defendidas pela CNTE. Além desse ato, a mobilização capitaneada pela CNTE continuou durante os anos de 2008 e 2009, isto, é, permanecendo após a sanção da Lei 11.738/2008, que instituiu o PSPN.

A instituição do PSPN deu-se no contexto de novas relações de poder entre Estado e sociedade civil, a partir do estabelecimento de estratégias de consenso, que foram sendo construídas no sentido de

[...] dar continuidade à execução de reformas estruturais, em especial aquelas que visam à desregulamentação das relações de trabalho (reformas da previdência, trabalhista e sindical) e aprofundar o modelo de radicalização democrática iniciado no segundo governo FHC. O governo Lula da Silva, pelo menos até seu segundo ano de mandato, vem mantendo a mesma política econômica monetarista de seu antecessor e, no plano político, vem tentando consolidar a formação do novo homem coletivo indispensável ao projeto de sociabilidade neoliberal da Terceira Via (NEVES, 2005, p. 95).

Foi nessa conjuntura de construção de novas relações de poder que a reforma da política educacional ensejou novas ações. Assim, deu-se a transformação do Fundef em Fundeb, operacionalizada por meio da aprovação da emenda à Constituição de ${ }^{\circ}$ 53/2006, mantendo-se a valorização profissional do magistério como questão central (CAMARGO, et al., 2009, p. 344), pelo menos em termos legais. A Lei n. 11.494 (BRASIL, 2007), que instituiu o Fundeb, mesmo face ao debate para que o Fundeb estendesse os recursos de $60 \%$ para $80 \%$, manteve a mesma lógica contábil e operacional do Fundef, fazendo prevalecer os $60 \%$ para despesas com MDE para pagamento de salários dos docentes nas esferas estadual e municipal.

Nesse contexto de reforma da política educacional e em decorrência das pressões por parte das corporações dos trabalhadores em educação, novos artifícios jurídicos legais foram instituídos, tal como a Lei 11.738/2008 que, segundo Camargo, define Piso Salarial Profissional Nacional nestes termos:

[...] valor do PSPN (que) foi fixado em $\mathrm{R} \$ 950,00$, sendo este fixado como o valor abaixo do qual os diferentes entes federados não poderiam estipular o vencimento inicial das carreiras do magistério público da educação básica com formação em nível médio na modalidade normal (art. 62 da LDB), com carga semanal de 40 horas 
de trabalho, podendo compreender as vantagens pecuniárias já existentes. A partir de 2009, tal piso deverá ser atualizado anualmente no mesmo percentual estabelecido pelo Fundeb para o valor aluno ano das séries iniciais do ensino fundamental, a ser reajustado de acordo com o INPC/IBGE. (CAMARGO et al, 2009, p. 345).

Foi nesse contexto que a CNTE reforçou o elo entre o Fundeb e o PSPN do magistério porque de acordo com o art. 5 da lei n. 11.738/2008, a correção do piso deveria pautar-se pelo mesmo percentual de reajuste do valor mínimo nacional do Fundeb. Portanto, o valor de $\mathrm{R} \$$ 950,00, definido para 2008, passaria a ser de R\$ 1.132,40 em 2009.

\subsection{A Lei 11.738/2008: um instrumento da política de valorização dos profissionais da educação básica}

É bem verdade que faz sentido a afirmação de Fernandes (1989) de que a chamada "transição" do regime de ditadura militar para o Estado de direito democrático social constituiu-se num marco na história das torpezas políticas no país, mas, ao mesmo tempo, também é verdadeiro que a CF de 1988 pode ser considerada como um marco histórico na busca de inversão do quadro caótico da educação pública no país. Por essa razão, a partir da promulgação da Carta Magna uma série de argumentos passaram a ser usados no intuito de inviabilizar a implantação do PSPN do magistério da educação básica pública brasileira, criando em todo o país diferentes formas de interpretação da concepção de valorização salarial docente. Alguns desses argumentos são destacados por Abicalil (2008, p. 73):

\footnotetext{
a) a disposição do inciso $\mathrm{V}$ do artigo $206 \mathrm{CF} / 1988$ levava ao entendimento de que o Piso Salarial Profissional era constitutivo de cada plano de carreira, em cada Estado, no Distrito Federal e em cada Município;

b) a perrogativa de propor leis que geram despesa é de iniciativa exclusiva do Poder Executivo;

c) sempre que institui despesa obrigatória para o Poder Público, deve ser indicada a fonte de receita capaz de honrar os compromissos dela derivados;

d) uma legislação nacional feriria o princípio da autonomia federativa, constituindo indevida interferência na organização de serviços públicos assegurados pelos Estados, pelo Distrito Federal e pelos Municípios;

e) faltava precisão na definição de quais seriam os profissionais da educação ou profissionais do magistério a quem se deveria aplicar o regramento do PSPN.
}

Em contrapartida, levando em conta esses argumentos, a Emenda Constitucional (BRASIL, 2006) fez uma série de alterações na CF de 1988 para viabilizar o Fundeb e, ao mesmo tempo, legalizar a instituição de um piso salarial nacional. A referida EC incluiu o piso salarial entre os princípios básicos a partir dos quais o ensino deve ser ministrado e determinou que a Lei regulamentadora dispusesse sobre o prazo para fixação, em lei 
específica, do piso salarial. Nesse sentido, a Medida Provisória (MP) n 339/2006, de 28 de dezembro de 2006, primeiro ato de regulamentação da EC n ${ }^{\circ} 53$ determinou:

\begin{abstract}
Art. 41. O Poder Público deverá fixar, em lei específica, no prazo de um ano contado da publicação desta Medida Provisória, piso salarial profissional nacional para os profissionais do magistério público da educação básica.

Parágrafo único. O Poder Executivo enviará ao Congresso Nacional o projeto de lei de que trata o caput no prazo de noventa dias contados da publicação desta Medida Provisória. (BRASIL, 2006).
\end{abstract}

Assim, em 28 de março de 2007, noventa dias após a publicação da MP nº 339/2006, o MEC, por meio da Exposição de Motivos (EM) n $n^{o}$ 016, justificou a necessidade de encaminhamento do Projeto de Lei ao Congresso Nacional. Conforme tal Exposição de Motivos, o Piso Salarial Profissional Nacional era uma demanda histórica dos profissionais da educação e o valor atribuído a ele correspondia à média mensal dos salários pagos aos profissionais da educação, pois, conforme apuração do Inep, tratava-se:

[...] do resgate histórico dos termos do Pacto Nacional pela Valorização do Magistério e Qualidade da Educação, firmado em 1994, pelo então Ministro da Educação Murílio Hingel, Presidente do Conselho de Reitores das Universidades Brasileiras (CRUB), José Carlos de Almeida, Presidente do Conselho Nacional de Secretários de Estado de Educação (CONSED), Marcos José de Castro Guerra, Presidente da União Nacional de Dirigentes Municipais de Educação (UNDIME), Maria Helena Guimarães Castro, Presidente do Forum de Conselhos Estaduais de Educação, Iara Silvia Lucas Wortmann, e Presidente da Confederação Nacional dos Trabalhadores na Educação, Horácio Francisco dos Reis Filho. O Pacto fixava em $\mathrm{R} \$ 300,00$, em valores de $1^{\circ}$ de julho de 1994, o piso nacional salarial dos professores, valor que, atualizado, corresponde aos $\mathrm{R} \$ 850,00$ contidos na proposta. (BRASIL, 2007)

A aglutinação de todas as iniciativas parlamentares que tratavam da instituição do Piso Salarial Profissional Nacional deu-se no Projeto de Lei $n^{\circ}$ 619, de 02 de abril de 2007, encaminhado ao Congresso Nacional. Abicalil (2008) esclarece que o Senado já havia aprovado em plenário o Projeto de Lei (Cristóvão Buarque) e todos os demais Projetos apensaram-se a ele na Câmara, inclusive aquele oriundo do Executivo. Esclarece, ainda, que o envio do PL do Piso foi uma iniciativa consagradora, colocando fim a uma tradição de omissão pela Presidência da República, sob a condução do presidente Luiz Inácio Lula da Silva. Assim, O PSPN pôde ser instituído por meio da Lei 11.738/2008, para regulamentar a alínea "e" do inciso III do caput do art. 60 do Ato das Disposições Constitucionais Transitórias (ADCT) (BRASIL, 2008).

A Lei 11.738 se estrutura em sete (7) artigos, os quais dispõem sobre a criação do PSPN. $\mathrm{O}$ art. $2^{\circ}$ da referida Lei dispõe especificamente sobre o PSPN e determina procedimentos que devem ser adotados na sua implementação nos entes federados, nestes termos: 
Art. $2^{\circ}$. O piso salarial profissional nacional para os profissionais do magistério público da educação básica será de $\mathrm{R} \$ 950$, (novecentos e cinqüenta reais) mensais, para a formação em nível médio, na modalidade Normal, prevista no que estabelece as diretrizes e bases da educação nacional.

$\S 1^{\circ} \mathrm{O}$ piso salarial profissional nacional é o valor abaixo do qual a União, os Estados, o Distrito Federal e os Municípios não poderão fixar o vencimento inicial das Carreiras do magistério público da educação básica, para a jornada de, no máximo, 40 (quarenta) horas semanais.

$\S 2^{\circ}$ Por profissionais do magistério público das educação básica entendem-se aqueles que desempenham as atividades de docência ou as de suporte pedagógico à docência, isto é, direção ou administração, planejamento, inspeção, supervisão, orientação e coordenação educacionais, exercidas no âmbito das unidades escolares de educação básica, em suas diversas etapas e modalidades, com a formação mínima determinada pela legislação federal de diretrizes e bases da educação.

$\S 3^{\circ}$ Os vencimentos iniciais referentes às demais jornadas de trabalho serão, no mínimo, proporcionais ao valor mencionado no caput deste artigo.

$\S 4^{\circ} \mathrm{Na}$ composição da jornada de trabalho, observar-se-á o limite máximo de 2/3 (dois terços) da carga horária para o desempenho das atividades de interação com os educandos.

$\S 5^{\circ}$ As disposições relativas ao piso salarial de que trata esta Lei serão aplicadas a todas as aposentadorias e pensões dos profissionais do magistério público da educação básica alcançadas pelo art. 7 da Emenda Constitucional no 41, de 19 de dezembro de 2003, e pela Emenda Constitucional no 47, de 5 de julho de 2005. (BRASIL, 2008)

$\mathrm{O}$ art. $2^{\circ}$ da Lei determinou o valor de $\mathrm{R} \$ 950,00$ como piso salarial para docentes com formação em nível médio com uma jornada de, no máximo, 40 horas semanais. No parágrafo $3^{\circ}$ desse artigo, esclareceu que os vencimentos iniciais referentes às demais jornadas de trabalho seriam proporcionais ao valor mencionado. Determinou também, no parágrafo $4^{\circ}$, que na composição da jornada de trabalho observar-se-ia o limite máximo de $2 / 3$ da carga horária para a formação e preparação das atividades de interação com os educandos e 1/3 para a formação e preparação para a docência.

O Piso Salarial Profissional Nacional refere-se ao vencimento inicial mínimo de qualquer uma das carreiras do magistério da educação básica - atividades de docência ou suporte pedagógico. Os valores podem e devem ser mais elevados nas unidades federativas que tiverem condições de remunerar melhor a categoria.

Até chegar à aprovação da Lei do Piso, as organizações sindicais, científicas e acadêmicas docentes tiveram papel primordial no contexto de aprovação do Fundeb, ocorrendo embates entre a CNTE, os podere executivo e legislativo. A CNTE dialogou com os trabalhadores em educação e conclamou a sociedade brasileira à luta, junto ao Congresso, no período de 2007 a 2009, visando à aprovação da respectiva Lei 11.738 (BRASIL, 2008), que veio regulamentar a carreira do magistério público em cumprimento aos dispositivos na CF de 1988, na Emenda Constitucional n ${ }^{\circ}$ 53/06 e na Lei 11.494 (BRASIL, 2007) que explicitou, no artigo 41, que o poder público deveria estabelecer o piso salarial nacional para os profissionais do magistério da educação básica por meio de lei específica. 
Por outro lado, as correntes contrárias à implantação do PSPN têm conseguido respaldo junto aos órgãos judiciais e até mesmo do próprio governo federal para protelar ou ignorar as determinações estabelecidas legalmente. Desse modo, após a promulgação da Lei 11.738/2008, em nome da autonomia dos estados e municípios, os governadores dos estados do Rio Grande do Sul, Santa Catarina, Paraná, Mato Grosso do Sul e Ceará - que contaram com o apoio dos governadores dos estados de São Paulo, Minas Gerais, Tocantins e do Distrito Federal resolveram questionar a legitimidade do governo central em relação à Lei do Piso.

Os estados questionaram alguns pontos da Lei 11.738/2008, sobretudo o estabelecimento da jornada de no máximo 40 horas semanais de trabalho, a composição da jornada; a vinculação do piso salarial ao vencimento inicial das carreiras dos profissionais do magistério da educação básica pública - não se admitindo computar gratificações, bônus e outros adicionais - os prazos para implementação e a data de vigência da Lei. Em verdade, o questionamento dos governadores recaiu sobre a legitimidade da União para legislar sobre tais assuntos, alegando que a fixação do regime de trabalho dos servidores estaduais e municipais, pelo pacto federativo, cabe a essas esferas do Estado; e mais, argumentaram que os custos gerados pela Lei representavam riscos às finanças dos entes federativos.

Como resposta parcial ao questionamento dos governadores, em 17 de dezembro de 2008, o STF proferiu medida cautelar que suspendeu provisoriamente dois pontos fundamentais da Lei: a composição da jornada de trabalho e a vinculação do piso salarial aos vencimentos iniciais das carreiras, passando a ser referência para o pagamento do piso e remuneração e não o vencimento inicial dos profissionais do magistério. Entretanto, essa ADI foi superada por decisão definitiva daquela Corte, em dois julgamentos consecutivos, realizados em 6 e 27 de abril de 2011, que declarou plenamente constitucional a Lei 11.738/2008, tanto no que se refere ao piso salarial quanto no que tange à composição da jornada de trabalho.

Com a decisão do STF, a Lei 11.738/2008 já deveria ter sido aplicada por todos os entes federados, entretanto, não é o que vem ocorrendo, conforme mostram os as Tabelas 01, 02 e os Gráficos 01, 02, 03 e 04, resultantes de levantamento de informações sobre a instituição do Piso Salarial Profissional Nacional e o cumprimento da hora/atividades dos professores das redes de educação básica nos estados e capitais, nos arquivos da Divape/Sase/MEC, em março de 2015. 
Tabela 01 - Vencimento e Hora Atividade dos professores das redes de educação básica nos estados

\begin{tabular}{|c|c|c|c|c|c|c|c|c|c|c|c|c|c|c|}
\hline \multirow{4}{*}{ UF } & \multicolumn{5}{|c|}{ Dados de Remuneração } & \multicolumn{5}{|c|}{ Dados de Remuneração } & \multicolumn{4}{|c|}{ Dados de jornada e horas-atividades } \\
\hline & \multicolumn{3}{|c|}{ Vencimento inicial pago atualmente } & \multirow{3}{*}{$\begin{array}{c}\text { Atualização } \\
\text { necessária } \\
\text { para alcançar } \\
\text { o Piso } \\
\text { (8,32\% Ref. } \\
\text { em 2014) } \\
\text { R\$ 1.917,78 }\end{array}$} & \multirow{3}{*}{$\begin{array}{l}\text { Valor Nominal } \\
\text { do Piso em } \\
2014 \text { (R\$) } \\
\text { (equivalente à } \\
\text { jornada) }\end{array}$} & \multicolumn{3}{|c|}{ Vencimento inicial pago atualmente } & \multirow{3}{*}{$\begin{array}{c}\text { Atualização } \\
\text { necessária para } \\
\text { alcançar o Piso } \\
\text { (8,32\% Ref. em } \\
2014) \\
\text { R\$ } 1.917,78\end{array}$} & \multirow{3}{*}{$\begin{array}{l}\text { Valor Nominal } \\
\text { do Piso em } \\
2014 \text { (R\$) } \\
\text { (equivalente à } \\
\text { jornada) }\end{array}$} & \multirow{3}{*}{$\begin{array}{l}\text { Carga } \\
\text { horária } \\
\text { (h/sem) }\end{array}$} & \multirow{3}{*}{$\begin{array}{l}\text { Horas- } \\
\text { Aulas } \\
\text { (h) }\end{array}$} & \multirow{2}{*}{\multicolumn{2}{|c|}{ Horas-Atividades }} \\
\hline & \multicolumn{3}{|c|}{ Nivel Médio } & & & \multicolumn{3}{|c|}{ Nivel Superior } & & & & & & \\
\hline & Valor (R\$) & $\begin{array}{l}\text { Jornada } \\
\text { (h/sem) }\end{array}$ & $\begin{array}{c}\text { Valor } \\
\text { equivalente à } \\
40 \mathrm{~h} / \mathrm{sem}(\mathrm{R} \$)\end{array}$ & & & Valor (R\$) & $\begin{array}{l}\text { Jornada } \\
\text { (h/sem) }\end{array}$ & $\begin{array}{l}\text { Valor equivalente } \\
\text { à } 40 \mathrm{~h} / \mathrm{sem}(\mathrm{R} \$)\end{array}$ & & & & & $\%$ & $\underset{\text { (h) }}{\text { Nominal }}$ \\
\hline AC & $\mathrm{R} \$ 1.439,32$ & 30 & $\mathrm{R} \$ 1.919,09$ & $0,0 \%$ & $\mathrm{R} \$ 1.439,32$ & $\mathrm{R} \$ 2.010,95$ & 30 & $\mathrm{R} \$ 2.681,27$ & $0,0 \%$ & $\mathrm{R} \$ 2.010,95$ & $30: 00$ & $20: 00$ & $33,3 \%$ & $10: 00$ \\
\hline AL & $\mathrm{R} \$ 1.917,78$ & 40 & $\mathrm{R} \$ 1.917,78$ & $0,0 \%$ & $\mathrm{R} \$ 1.917,78$ & $\mathrm{R} \$ 2.651,80$ & 40 & $\mathrm{R} \$ 2.651,80$ & $0,0 \%$ & $\mathrm{R} \$ 2.651,80$ & $40: 00$ & $26: 40$ & $33,3 \%$ & $13: 20$ \\
\hline AM & $\mathrm{R} \$ 2.352,46$ & 40 & $\mathrm{R} \$ 2.352,46$ & $0,0 \%$ & $\mathrm{R} \$ 2.352,46$ & $\mathrm{R} \$ 3.133,80$ & 40 & $\mathrm{R} \$ 3.133,80$ & $0,0 \%$ & $\mathrm{R} \$ 3.133,80$ & $40: 00$ & $32: 00$ & $20,0 \%$ & 08:00 \\
\hline AP & $R \$ 2.724,00$ & 40 & $R \$ 2.724,00$ & $0,0 \%$ & $\mathrm{R} \$ 2.724,00$ & $R \$ 3.416,23$ & 40 & $R \$ 3.416,23$ & $0,0 \%$ & $R \$ 3.416,23$ & 40:00 & $24: 00$ & $40,0 \%$ & $16: 00$ \\
\hline BA & & & \#DIV/0! & \#DIV/0! & & $\mathrm{R} \$ 930,42$ & 20 & $\mathrm{R} \$ 1.860,84$ & $3,1 \%$ & $\mathrm{R} \$ 958,89$ & 40:00 & $28: 00$ & $30,0 \%$ & $12: 00$ \\
\hline CE & $\mathrm{R} \$ 1.723,73$ & 40 & $\mathrm{R} \$ 1.723,73$ & $11,3 \%$ & $\mathrm{R} \$ 1.723,73$ & $\mathrm{R} \$ 1.815,54$ & 40 & $\mathrm{R} \$ 1.815,54$ & $5,6 \%$ & $\mathrm{R} \$ 1.815,54$ & $40: 00$ & $27: 00$ & $32,5 \%$ & $13: 00$ \\
\hline DF & $\mathrm{R} \$ 3.048,50$ & 40 & $\mathrm{R} \$ 3.048,50$ & $0,0 \%$ & $\mathrm{R} \$ 3.048,50$ & $\mathrm{R} \$ 3.838,87$ & 40 & $\mathrm{R} \$ 3.838,87$ & $0,0 \%$ & $\mathrm{R} \$ 3.838,87$ & $40: 00$ & $26: 40$ & $33,3 \%$ & $13: 20$ \\
\hline ES & $\mathrm{R} \$ 1.198,61$ & 25 & $\mathrm{R} \$ 1.917,78$ & $0,0 \%$ & $\mathrm{R} \$ 1.198,61$ & $\mathrm{R} \$ 1.982,55$ & 25 & $\mathrm{R} \$ 3.172,08$ & $0,0 \%$ & $\mathrm{R} \$ 1.982,55$ & $25: 00$ & $18: 00$ & $28,0 \%$ & 07:00 \\
\hline GO & $\mathrm{R} \$ 1.758,94$ & 40 & $\mathrm{R} \$ 1.758,94$ & $9,0 \%$ & $\mathrm{R} \$ 1.758,94$ & $\mathrm{R} \$ 2.570,08$ & 40 & $\mathrm{R} \$ 2.570,08$ & $0,0 \%$ & $\mathrm{R} \$ 2.570,08$ & $40: 00$ & $28: 00$ & $30,0 \%$ & $12: 00$ \\
\hline MA & $\mathrm{R} \$ 959,10$ & 20 & $\mathrm{R} \$ 1.918,20$ & $0,0 \%$ & $\mathrm{R} \$ 959,10$ & $\mathrm{R} \$ 1.221,92$ & 20 & $\mathrm{R} \$ 2.443,84$ & $0,0 \%$ & $\mathrm{R} \$ 1.221,92$ & $20: 00$ & 13:00 & $35,0 \%$ & 07:00 \\
\hline MG & $\mathrm{R} \$ 1.237,01$ & 24 & $\mathrm{R} \$ 2.061,68$ & $0,0 \%$ & $\mathrm{R} \$ 1.237,01$ & $\mathrm{R} \$ 1.455,30$ & 24 & $\mathrm{R} \$ 2.425,50$ & $0,0 \%$ & $\mathrm{R} \$ 1.455,30$ & $24: 00$ & $16: 00$ & $33,3 \%$ & 08:00 \\
\hline MS & $R \$ 2.662,83$ & 40 & $R \$ 2.662,83$ & $0,0 \%$ & $\mathrm{R} \$ 2.662,83$ & $\mathrm{R} \$ 3.994,25$ & 40 & $\mathrm{R} \$ 3.994,25$ & $0,0 \%$ & $\mathrm{R} \$ 3.994,25$ & $40: 00$ & $26: 00$ & $35,0 \%$ & $14: 00$ \\
\hline MT & $\mathrm{R} \$ 1.739,28$ & 30 & $\mathrm{R} \$ 2.319,04$ & $0,0 \%$ & $\mathrm{R} \$ 1.739,28$ & $\mathrm{R} \$ 2.608,90$ & 30 & $R \$ 3.478,53$ & $0,0 \%$ & $\mathrm{R} \$ 2.608,90$ & $30: 00$ & $20: 00$ & $33,3 \%$ & $10: 00$ \\
\hline PA & $\mathrm{R} \$ 1.697,37$ & 40 & $\mathrm{R} \$ 1.697,37$ & $13,0 \%$ & $\mathrm{R} \$ 1.697,37$ & $\mathrm{R} \$ 1.705,86$ & 40 & $\mathrm{R} \$ 1.705,86$ & $12,4 \%$ & $\mathrm{R} \$ 1.705,86$ & $40: 00$ & $32: 00$ & $20,0 \%$ & 08:00 \\
\hline PB & $\mathrm{R} \$ 1.525,00$ & 30 & $\mathrm{R} \$ 2.033,33$ & $0,0 \%$ & $\mathrm{R} \$ 1.525,00$ & $\mathrm{R} \$ 1.596,00$ & 30 & $\mathrm{R} \$ 2.128,00$ & $0,0 \%$ & $\mathrm{R} \$ 1.596,00$ & $30: 00$ & $20: 00$ & $33,3 \%$ & $10: 00$ \\
\hline $\mathrm{PE}$ & $\mathrm{R} \$ 1.698,00$ & 40 & $\mathrm{R} \$ 1.698,00$ & $12,9 \%$ & $\mathrm{R} \$ 1.698,00$ & $\mathrm{R} \$ 1.901,86$ & 40 & $\mathrm{R} \$ 1.901,86$ & $0,8 \%$ & $\mathrm{R} \$ 1.901,86$ & $40: 00$ & $28: 00$ & $30,0 \%$ & $12: 00$ \\
\hline PI & $\mathrm{R} \$ 2.221,75$ & 40 & $\mathrm{R} \$ 2.221,75$ & $0,0 \%$ & $\mathrm{R} \$ 2.221,75$ & $R \$ 2.634,65$ & 40 & $R \$ 2.634,65$ & $0,0 \%$ & $R \$ 2.634,65$ & $40: 00$ & $28: 00$ & $30,0 \%$ & $12: 00$ \\
\hline PR & & & \#DIV/0! & \#DIV/0! & & $\mathrm{R} \$ 1.236,61$ & 20 & $\mathrm{R} \$ 2.473,22$ & $0,0 \%$ & $\mathrm{R} \$ 1.236,61$ & $20: 00$ & 13:00 & $35,0 \%$ & 07:00 \\
\hline RJ & $\mathrm{R} \$ 1.880,32$ & 40 & $\mathrm{R} \$ 1.880,32$ & $2,0 \%$ & $\mathrm{R} \$ 1.880,32$ & $\mathrm{R} \$ 2.948,33$ & 40 & $\mathrm{R} \$ 2.948,33$ & $0,0 \%$ & $\mathrm{R} \$ 2.948,33$ & $40: 00$ & $30: 00$ & $25,0 \%$ & $10: 00$ \\
\hline RN & $\mathrm{R} \$ 1.438,67$ & 30 & $\mathrm{R} \$ 1.918,23$ & $0,0 \%$ & $\mathrm{R} \$ 1.438,67$ & $\mathrm{R} \$ 2.013,32$ & 30 & $R \$ 2.684,43$ & $0,0 \%$ & $\mathrm{R} \$ 2.013,32$ & $30: 00$ & $20: 00$ & $33,3 \%$ & $10: 00$ \\
\hline RO & $\mathrm{R} \$ 1.536,36$ & 40 & $\mathrm{R} \$ 1.536,36$ & $24,8 \%$ & $\mathrm{R} \$ 1.536,36$ & $\mathrm{R} \$ 2.016,59$ & 40 & $\mathrm{R} \$ 2.016,59$ & $0,0 \%$ & $\mathrm{R} \$ 2.016,59$ & $40: 00$ & $27: 00$ & $32,5 \%$ & 13:00 \\
\hline RR & $\mathrm{R} \$ 1.597,21$ & 25 & $\mathrm{R} \$ 2.555,54$ & $0,0 \%$ & $\mathrm{R} \$ 1.597,21$ & $\mathrm{R} \$ 2.218,04$ & 25 & $\mathrm{R} \$ 3.548,86$ & $0,0 \%$ & $\mathrm{R} \$ 2.218,04$ & $25: 00$ & $16: 00$ & $36,0 \%$ & 09:00 \\
\hline RS & $\mathrm{R} \$ 630,10$ & 20 & $\mathrm{R} \$ 1.260,20$ & $52,2 \%$ & $\mathrm{R} \$ 630,10$ & $\mathrm{R} \$ 1.165,69$ & 20 & $\mathrm{R} \$ 2.331,38$ & $0,0 \%$ & $\mathrm{R} \$ 1.025,04$ & $20: 00$ & 13:00 & $35,0 \%$ & 07:00 \\
\hline SC & $\mathrm{R} \$ 1.917,78$ & 40 & $\mathrm{R} \$ 1.917,78$ & $0,0 \%$ & $\mathrm{R} \$ 1.917,78$ & $\mathrm{R} \$ 1.917,78$ & 40 & $\mathrm{R} \$ 1.917,78$ & $0,0 \%$ & $\mathrm{R} \$ 1.917,78$ & $40: 00$ & $32: 00$ & $20,0 \%$ & 08:00 \\
\hline SE & $\mathrm{R} \$ 1.917,78$ & 40 & $\mathrm{R} \$ 1.917,78$ & $0,0 \%$ & $\mathrm{R} \$ 1.917,78$ & $\mathrm{R} \$ 1.943,53$ & 40 & $\mathrm{R} \$ 1.943,53$ & $0,0 \%$ & $\mathrm{R} \$ 1.943,53$ & $40: 00$ & $25: 00$ & $37,5 \%$ & $15: 00$ \\
\hline SP & $\mathrm{R} \$ 2.086,93$ & 40 & $\mathrm{R} \$ 2.086,93$ & $0,0 \%$ & $\mathrm{R} \$ 2.086,93$ & $\mathrm{R} \$ 2.415,89$ & 40 & $\mathrm{R} \$ 2.415,89$ & $0,0 \%$ & $\mathrm{R} \$ 2.415,89$ & 40:00 & $26: 40$ & $33,3 \%$ & $13: 20$ \\
\hline TO & $\mathrm{R} \$ 1.555,42$ & 40 & $\mathrm{R} \$ 1.555,42$ & $23,3 \%$ & $\mathrm{R} \$ 1.555,42$ & $\mathrm{R} \$ 3.582,62$ & 40 & $\mathrm{R} \$ 3.582,62$ & $0,0 \%$ & $\mathrm{R} \$ 3.582,62$ & $40: 00$ & $24: 00$ & $40,0 \%$ & $16: 00$ \\
\hline
\end{tabular}

Fonte: Pasta Pública da Divape/Sase/MEC - março de 2015 
Tabela 02 - Vencimento e Hora-Atividade dos professores das redes de educação básica nas capitais.

\begin{tabular}{|c|c|c|c|c|c|c|c|c|c|c|c|c|c|c|}
\hline \multirow{4}{*}{ UF } & \multicolumn{5}{|c|}{ Dados de Remuneração } & \multicolumn{5}{|c|}{ Dados de Remuneração } & \multicolumn{4}{|c|}{ Dados de jornada e horas-atividades } \\
\hline & \multicolumn{3}{|c|}{ Vencimento inicial pago atualmente } & \multirow{3}{*}{$\begin{array}{c}\text { Atualização } \\
\text { necessária } \\
\text { para alcançar } \\
\text { o Piso } \\
(8,32 \% \text { Ref. } \\
\text { em 2014) } \\
\text { R\$ 1.917,78 }\end{array}$} & \multirow{3}{*}{$\begin{array}{l}\text { Valor Nominal } \\
\text { do Piso em } \\
2015 \text { (R\$) } \\
\text { (equivalente à } \\
\text { jornada) }\end{array}$} & \multicolumn{3}{|c|}{ Vencimento inicial pago atualmente } & \multirow{3}{*}{$\begin{array}{c}\text { Atualização } \\
\text { necessária } \\
\text { para alcançar } \\
\text { o Piso } \\
(8,32 \% \text { Ref. } \\
\text { em 2014) } \\
\text { R\$ 1.917,78 }\end{array}$} & \multirow{3}{*}{$\begin{array}{c}\text { Valor Nominal } \\
\text { do Piso em } 2015 \\
\text { (R\$) } \\
\text { (equivalente à } \\
\text { jornada) }\end{array}$} & \multirow{3}{*}{$\begin{array}{c}\text { Carga } \\
\text { horária } \\
\text { (h/sem) }\end{array}$} & \multirow{3}{*}{$\begin{array}{l}\text { Horas- } \\
\text { Aulas } \\
\text { (h) }\end{array}$} & \multirow{2}{*}{\multicolumn{2}{|c|}{ Horas-Atividades }} \\
\hline & \multicolumn{3}{|c|}{ Nivel Médio } & & & \multicolumn{3}{|c|}{ Nivel Superior } & & & & & & \\
\hline & Valor (R\$) & $\begin{array}{l}\text { Jornada } \\
\text { (h/sem) }\end{array}$ & $\begin{array}{l}\text { Valor equivalente } \\
\text { à } 40 \mathrm{~h} / \mathrm{sem}(\mathrm{R} \$)\end{array}$ & & & Valor (R\$) & $\begin{array}{l}\text { Jornada } \\
\text { (h/sem) }\end{array}$ & $\begin{array}{c}\text { Valor } \\
\text { equivalente à } \\
40 \mathrm{~h} / \mathrm{sem}(\mathrm{R} \$)\end{array}$ & & & & & $\%$ & Nominal (h) \\
\hline Aracaju/SE & $\mathrm{R} \$ 1.614,01$ & 40 & $\mathrm{R} \$ 1.614,01$ & $18,8 \%$ & $\mathrm{R} \$ 1.614,01$ & $\mathrm{R} \$ 1.878,68$ & 40 & $\mathrm{R} \$ 1.878,68$ & $2,1 \%$ & $\mathrm{R} \$ 1.878,68$ & $40: 00$ & $20: 00$ & $50,0 \%$ & $20: 00$ \\
\hline B. Horizonte/MG & $\mathrm{R} \$ 1.348,67$ & 40 & $\mathrm{R} \$ 1.348,67$ & $42,2 \%$ & $\mathrm{R} \$ 1.348,67$ & $\mathrm{R} \$ 2.092,22$ & 40 & $\mathrm{R} \$ 2.092,22$ & $0,0 \%$ & $\mathrm{R} \$ 2.092,22$ & 40:00 & $22: 30$ & $43,8 \%$ & $17: 30$ \\
\hline Belém/PA & $\mathrm{R} \$ 1.963,56$ & 40 & $\mathrm{R} \$ 1.963,56$ & $0,0 \%$ & $\mathrm{R} \$ 1.963,56$ & $\mathrm{R} \$ 2.454,00$ & 40 & $\mathrm{R} \$ 2.454,00$ & $0,0 \%$ & $\mathrm{R} \$ 2.454,00$ & 40:00 & $25: 00$ & $37,5 \%$ & 15:00 \\
\hline Boa Vista/RR & $\mathrm{R} \$ 1.650,00$ & 25 & $\mathrm{R} \$ 2.640,00$ & $0,0 \%$ & $\mathrm{R} \$ 1.650,00$ & $\mathrm{R} \$ 1.980,00$ & 25 & $\mathrm{R} \$ 3.168,00$ & $0,0 \%$ & $\mathrm{R} \$ 1.980,00$ & $25: 00$ & $20: 00$ & $20,0 \%$ & 05:00 \\
\hline Campo Grande/MS & $R \$ 3.394,74$ & 40 & $\mathrm{R} \$ 3.394,74$ & $0,0 \%$ & $\mathrm{R} \$ 3.394,74$ & $R \$ 5.092,13$ & 40 & $R \$ 5.092,13$ & $0,0 \%$ & $R \$ 5.092,13$ & $40: 00$ & $26: 00$ & $35,0 \%$ & $14: 00$ \\
\hline Cuiabá/MT & $\mathrm{R} \$ 1.279,77$ & 20 & $\mathrm{R} \$ 2.559,54$ & $0,0 \%$ & $\mathrm{R} \$ 1.279,77$ & $\mathrm{R} \$ 1.828,26$ & 20 & $\mathrm{R} \$ 3.656,52$ & $0,0 \%$ & $\mathrm{R} \$ 1.828,26$ & 40:00 & $32: 00$ & $20,0 \%$ & 08:00 \\
\hline Curitiba/PR & $\mathrm{R} \$ 1.054,00$ & 20 & $\mathrm{R} \$ 2.108,00$ & $0,0 \%$ & $\mathrm{R} \$ 1.054,00$ & $\mathrm{R} \$ 1.614,72$ & 20 & $\mathrm{R} \$ 3.229,44$ & $0,0 \%$ & $\mathrm{R} \$ 1.614,72$ & $20: 00$ & $13: 00$ & $35,0 \%$ & 07:00 \\
\hline Florianópolis/SC & $\mathrm{R} \$ 2.036,00$ & 40 & $\mathrm{R} \$ 2.036,00$ & $0,0 \%$ & $\mathrm{R} \$ 2.036,00$ & $\mathrm{R} \$ 2.088,00$ & 40 & $\mathrm{R} \$ 2.088,00$ & $0,0 \%$ & $\mathrm{R} \$ 2.088,00$ & $40: 00$ & $32: 00$ & $20,0 \%$ & 08:00 \\
\hline Fortaleza/CE & $\mathrm{R} \$ 1.943,04$ & 40 & $\mathrm{R} \$ 1.943,04$ & $0,0 \%$ & $\mathrm{R} \$ 1.943,04$ & $R \$ 2.353,70$ & 40 & $\mathrm{R} \$ 2.353,70$ & $0,0 \%$ & $R \$ 2.535,70$ & 40:00 & $27: 00$ & $32,5 \%$ & 13:00 \\
\hline Goiânia/GO & $R \$ 2.056,86$ & 40 & $R \$ 2.056,86$ & $0,0 \%$ & $\mathrm{R} \$ 2.056,86$ & $R \$ 2.556,68$ & 40 & $\mathrm{R} \$ 2.556,68$ & $0,0 \%$ & $R \$ 2.556,68$ & $30: 00$ & 21:00 & $30,0 \%$ & 09:00 \\
\hline João Pessoal/PB & $\mathrm{R} \$ 1.403,79$ & 30 & $\mathrm{R} \$ 1.871,72$ & $2,5 \%$ & $\mathrm{R} \$ 1.403,79$ & $\mathrm{R} \$ 1.871,81$ & 30 & $\mathrm{R} \$ 2.495,75$ & $0,0 \%$ & $\mathrm{R} \$ 1.871,81$ & $30: 00$ & $20: 00$ & $33,3 \%$ & $10: 00$ \\
\hline Macapá/AP & $\mathrm{R} \$ 1.697,40$ & 40 & $\mathrm{R} \$ 1.697,40$ & $13,0 \%$ & $\mathrm{R} \$ 1.697,40$ & $\mathrm{R} \$ 1.871,74$ & 40 & $\mathrm{R} \$ 1.871,74$ & $2,5 \%$ & $\mathrm{R} \$ 1.917,78$ & 40:00 & $20: 00$ & $50,0 \%$ & $20: 00$ \\
\hline Maceió/AL & $\mathrm{R} \$ 2.147,65$ & 40 & $\mathrm{R} \$ 2.147,65$ & $0,0 \%$ & $\mathrm{R} \$ 2.147,65$ & $R \$ 3.221,46$ & 40 & $R \$ 3.221,46$ & $0,0 \%$ & $R \$ 3.221,46$ & $40: 00$ & $30: 00$ & $25,0 \%$ & $10: 00$ \\
\hline Manaus/AM & $\mathrm{R} \$ 1.479,39$ & 20 & $\mathrm{R} \$ 2.958,78$ & $0,0 \%$ & $\mathrm{R} \$ 1.479,39$ & $\mathrm{R} \$ 1.479,39$ & 20 & $\mathrm{R} \$ 2.958,78$ & $0,0 \%$ & $\mathrm{R} \$ 1.479,39$ & $40: 00$ & $36: 00$ & $10,0 \%$ & 04:00 \\
\hline Natal/RN & $\mathrm{R} \$ 1.347,24$ & 20 & $\mathrm{R} \$ 2.694,48$ & $0,0 \%$ & $\mathrm{R} \$ 1.347,24$ & $\mathrm{R} \$ 1.815,72$ & 20 & $R \$ 3.631,44$ & $0,0 \%$ & $\mathrm{R} \$ 1.815,72$ & $20: 00$ & $16: 00$ & $20,0 \%$ & 04:00 \\
\hline Palmas/TO & $\mathrm{R} \$ 1.917,78$ & 40 & $\mathrm{R} \$ 1.917,78$ & $0,0 \%$ & $\mathrm{R} \$ 1.917,78$ & $\mathrm{R} \$ 3.260,64$ & 40 & $R \$ 3.260,64$ & $0,0 \%$ & $\mathrm{R} \$ 3.260,64$ & $40: 00$ & $26: 40$ & $33,3 \%$ & $13: 20$ \\
\hline Porto Alegre/RS & $\mathrm{R} \$ 1.238,00$ & 20 & $\mathrm{R} \$ 2.476,00$ & $0,0 \%$ & $\mathrm{R} \$ 1.238,00$ & $\mathrm{R} \$ 1.915,30$ & 20 & $\mathrm{R} \$ 3.830,60$ & $0,0 \%$ & $\mathrm{R} \$ 1.915,30$ & $20: 00$ & $15: 00$ & $25,0 \%$ & 05:00 \\
\hline Porto Velho/RO & $R \$ 1.697,48$ & 40 & $\mathrm{R} \$ 1.697,48$ & $13,0 \%$ & $\mathrm{R} \$ 1.697,48$ & $\mathrm{R} \$ 2.119,27$ & 40 & $\mathrm{R} \$ 2.119,27$ & $0,0 \%$ & $\mathrm{R} \$ 2.119,27$ & $40: 00$ & $30: 00$ & $25,0 \%$ & $10: 00$ \\
\hline Recife/PE & $\mathrm{R} \$ 1.486,20$ & 29 & $\mathrm{R} \$ 2.049,93$ & $0,0 \%$ & $\mathrm{R} \$ 1.486,20$ & $\mathrm{R} \$ 2.132,95$ & 29 & $\mathrm{R} \$ 2.942,00$ & $0,0 \%$ & $\mathrm{R} \$ 2.132,95$ & $29: 00$ & $25: 00$ & $13,8 \%$ & 04:00 \\
\hline Rio Branco/AC & $\mathrm{R} \$ 952,21$ & 25 & $\mathrm{R} \$ 1.523,54$ & $25,9 \%$ & $\mathrm{R} \$ 952,21$ & $\mathrm{R} \$ 1.865,16$ & 25 & $\mathrm{R} \$ 2.984,26$ & $0,0 \%$ & $\mathrm{R} \$ 1.865,16$ & $25: 00$ & $20: 00$ & $20,0 \%$ & 05:00 \\
\hline Rio de Janeiro/RJ & $\mathrm{R} \$ 1.505,59$ & 22,5 & $R \$ 2.676,60$ & $0,0 \%$ & $\mathrm{R} \$ 1.505,59$ & $\mathrm{R} \$ 4.410,31$ & 40 & $\mathrm{R} \$ 4.410,31$ & $0,0 \%$ & $\mathrm{R} \$ 4.410,31$ & 40:00 & $28: 00$ & $30,0 \%$ & $12: 00$ \\
\hline Salvador/BA & $\mathrm{R} \$ 1.917,78$ & 40 & $\mathrm{R} \$ 1.917,78$ & $0,0 \%$ & $\mathrm{R} \$ 1.917,78$ & $\mathrm{R} \$ 2.269,92$ & 40 & $\mathrm{R} \$ 2.269,92$ & $0,0 \%$ & $R \$ 2.269,92$ & $40: 00$ & $28: 00$ & $30,0 \%$ & $12: 00$ \\
\hline São Luís/MA & $R \$ 2.251,38$ & 40 & $\mathrm{R} \$ 2.251,38$ & $0,0 \%$ & $\mathrm{R} \$ 2.251,38$ & $\mathrm{R} \$ 3.720,25$ & 40 & $\mathrm{R} \$ 3.720,25$ & $0,0 \%$ & $\mathrm{R} \$ 3.720,25$ & $40: 00$ & $26: 00$ & $35,0 \%$ & $14: 00$ \\
\hline São Paulo/SP & $R \$ 2.483,29$ & 40 & $R \$ 2.483,29$ & $0,0 \%$ & $R \$ 2.483,29$ & $\mathrm{R} \$ 3.000,00$ & 40 & $\mathrm{R} \$ 3.000,00$ & $0,0 \%$ & $R \$ 3.000,00$ & $40: 00$ & $25: 00$ & $37,5 \%$ & $15: 00$ \\
\hline Teresina/PI & $\mathrm{R} \$ 2.221,75$ & 40 & $\mathrm{R} \$ 2.221,75$ & $0,0 \%$ & $\mathrm{R} \$ 2.221,75$ & $\mathrm{R} \$ 2.634,65$ & 40 & $\mathrm{R} \$ 2.634,65$ & $0,0 \%$ & $\mathrm{R} \$ 2.070,11$ & 40:00 & $26: 00$ & $35,0 \%$ & $14: 00$ \\
\hline Vitória/ES & $\mathrm{R} \$ 1.081,00$ & 25 & $\mathrm{R} \$ 1.729,60$ & $10,9 \%$ & $\mathrm{R} \$ 1.081,00$ & $\mathrm{R} \$ 1.847,56$ & 25 & $\mathrm{R} \$ 2.956,10$ & $0,0 \%$ & $\mathrm{R} \$ 1.847,56$ & $25: 00$ & $20: 00$ & $20,0 \%$ & 05:00 \\
\hline
\end{tabular}

Fonte: Pasta Pública da Divape/Sase/MEC - março de 2015 


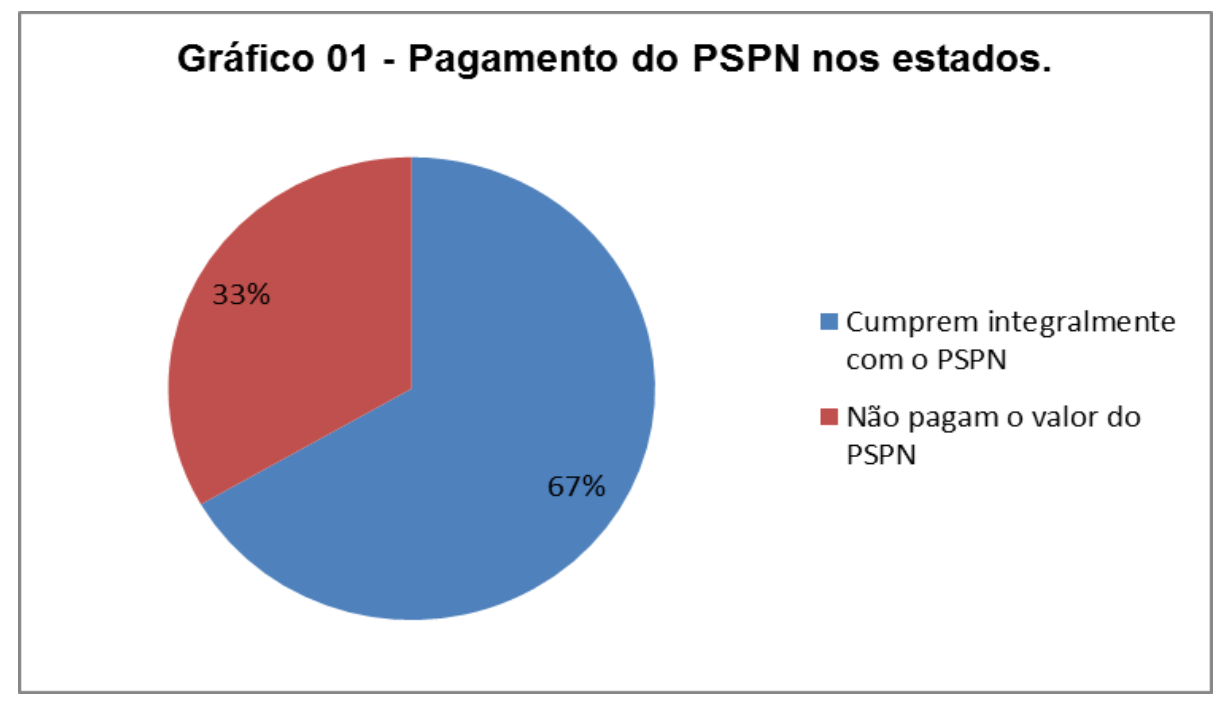

Fonte: Pasta Pública da Divape/Sase/MEC - março de 2015

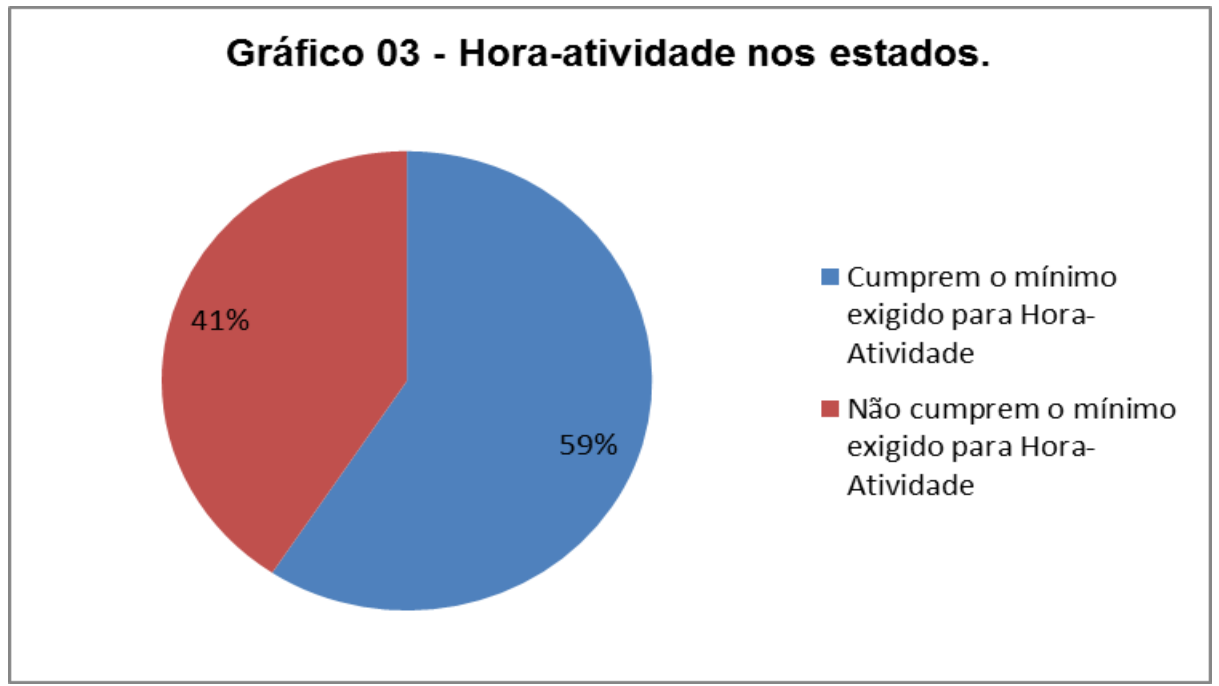

Fonte: Pasta Pública da Divape/Sase/MEC - março de 2015

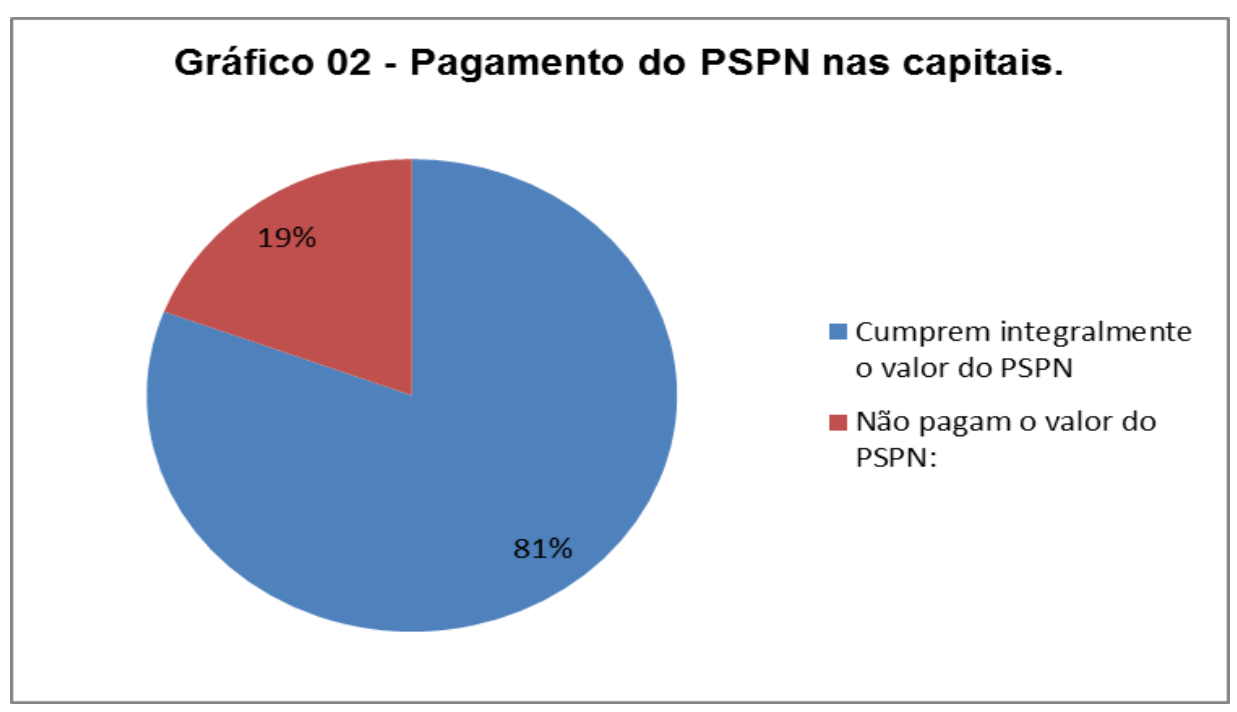

Fonte: Pasta Pública da Divape/Sase/MEC - março de 2015

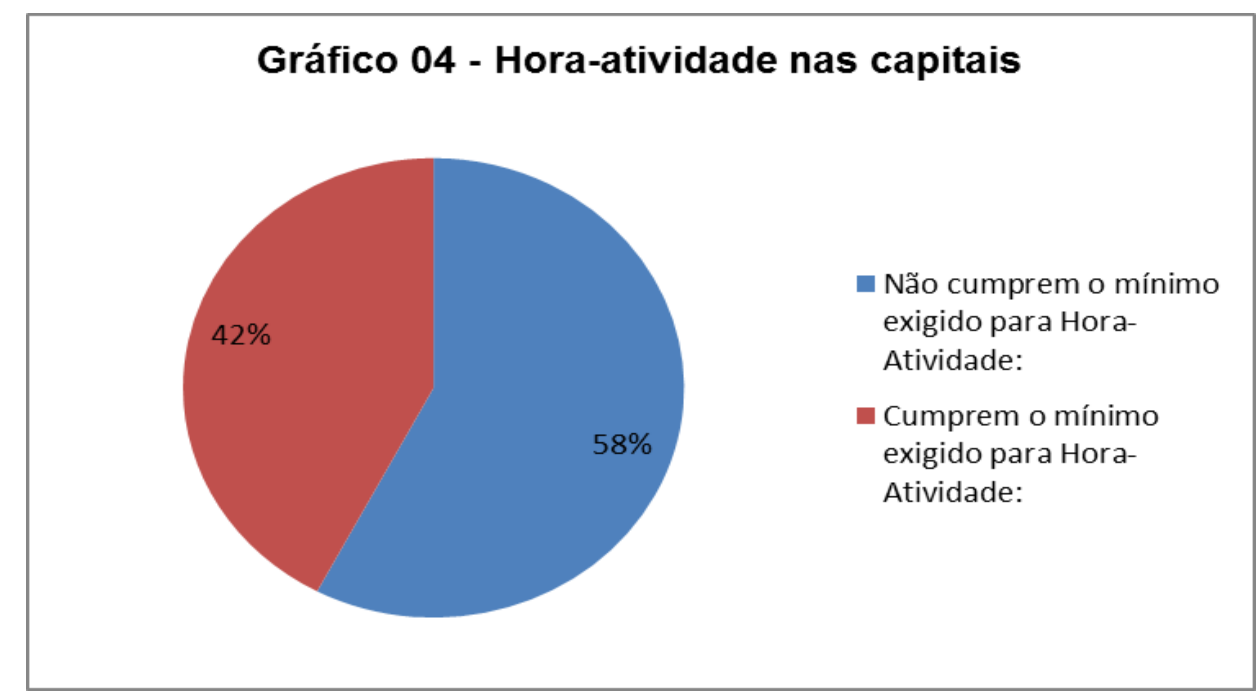

Fonte: Pasta Pública da Divape/Sase/MEC - março de 2015 
A Tabela 01 apresenta informações sobre o cumprimento da Lei 11.738/2008 no que se refere ao vencimento inicial, jornada de trabalho e horas/atividades dos professores da educação básica de nível médio e superior nas redes de ensino estaduais. Nos estados da Bahia e Paraná não há mais professores de nível médio nas redes públicas de ensino.

No conjunto de 27 unidades federadas, 26 estados e o Distrito Federal, oito estados ainda não pagam o PSPN no valor de $\mathrm{R} \$ 1.917,78$ (Hum mil, novecentos e dezete reais e setenta e oito centavos), de acordo com a Lei 11.738/2008. São eles: Ceará, Goiás, Pará, Pernambuco, Rio de Janeiro, Rondônia, Rio Grande do Sul e Tocantins.

A Tabela 01 apresenta, também, a porcentagem necessária para que os estados paguem o PSPN de acordo com a Lei. Com relação às horas/atividades, 11 estados ainda não cumprem o que determina a Lei 11.738/2008. São eles: Amazonas, Bahia, Ceará, Espírito Santo, Goiás, Pará, Pernambuco, Piaui, Rio de Janeiro, Rondônia e Santa Catarina. A Tabela 01 mostra, em porcentagem, o quantitativo de horas/atividades que faltam para ser cumprido o total estabelecido pela Lei, que é de 33,3\% da carga horária dos professores.

A Tabela 02 apresenta a implantação da Lei 11.738/2008 no que se refere ao vencimento inicial, jornada de trabalho e horas/atividades dos professores da educação básica de nível médio nas redes de ensino nas capitais dos estados brasileiros. Nos estados da Bahia e Paraná não há mais professores de nível médio nas redes públicas de ensino.

No conjunto de 27 capitais, 26 de estados e do Distrito Federal, cinco capitais ainda não pagam o PSPN, conforme determina a Lei 11.738/2008. São elas: Aracaju (SE), Belo Horizonte (MG), Porto Velho (RO), Rio Branco (AC) e Vitória (ES). A Tabela 02 apresenta a porcentagem necessária para que as capitais façam o pagamento do PSPN, conforme a Lei. Com relação às horas/atividades, 15 capitais ainda não cumprem o que determina a Lei. São elas: Boa Vista (RR), Cuiabá (MT), Florianópolis (SC), Fortaleza (CE), Goiânia (GO), Maceió (AL), Manaus (AM), Natal (RN), Porto Alegre (RS), Porto Velho (RO), Recife (PE), Rio Branco (AC), Rio de Janeiro (RJ), Salvador (BA) e Vitória (ES). A Tabela 02 mostra, em porcentagem, o quantitativo de horas/atividades que faltam para ser cumprido o total estabelecido pela Lei nas capitais, que é de 33,3\% da carga horária dos professores.

O gráfico 01 apresenta, em porcentagem, o cumprimento e o não cumprimento da Lei $11.738 / 2008$ no que se refere ao vencimento inicial dos professores nos estados. Das 27 unidades federadas (estados e Distrito Federal) 67\% cumprem o que estabelece a Lei; e 33\% ainda não cumprem.

O Gráfico 02 mostra, em porcentagem, o cumprimento e o não cumprimento da Lei $11.738 / 2008$ no que tange ao vencimento inicial dos professores nas capitais dos estados 
brasileiros. No conjunto de 27 capitais, 26 de estados e do Distrito Federal, 81\% cumprem integralmente o valor do PSPN; e 19\% não pagam o valor do PSPN.

O Gráfico 03 mostra, em porcentagem, o cumprimento e o não cumprimento da Lei 11.738/2008 no tocante às horas/atividades nos estados brasileiros. Das 27 unidades federadas, $59 \%$ cumprem e $41 \%$ não cumprem o que determina a Lei.

O Gráfico 04 apresenta, em porcentagem, o cumprimento e o não cumprimento da Lei no que se refere às horas/atividades nas capitais dos estados brasileiros. Das 27 unidades federadas, $58 \%$ cumprem e $48 \%$ não cumprem o estabelecido em Lei.

As Tabelas e os Gráficos mostram que a maioria dos estados e das capitais tem dado atenção à questão que já deveria ter sido resolvida, uma vez que a valorização salarial dos professores é considerada como um fator social essencial para elevar o padrão de desenvolvimento da educação com qualidade no país.

Geralmente, os argumentos utilizados pelos entes federados para o não cumprimento da Lei 11.738/2008 recaem sobre a questão do impacto na folha de pagamento dos estados e municípios, entretanto, o que se percebe nas mesas de negociações do Ministério da Educação com os entes federados é que o pano de fundo dos embates sobre a implantação do PSPN continua sendo as intrincadas relações federativas historicamente construídas no país. Foi por esse motivo que os cinco governadores estaduais resolveram questionar o modelo federativo que tende a se sustentar na especificidade do Estado federal, que é o compartilhamento da soberania entre o governo central [...] e os governos subnacionais (ABRUCIO, 2006. p. 92).

A interpretação do modelo federativo por parte dos governadores indica muito mais um tensionamento político com a esfera federal, mostrando o quão forte ainda é o regional no contexto político do país, do que a disposição de promover um exercício de equacionamento das finanças públicas em prol da construção de um pacto federativo compensatório e equilibrador das desigualdades regionais.

Apesar desses obstáculos, a instituição do PSPN é considerada como um avanço ao elevar o poder econômico-financeiro dos profissionais da educação básica, valorizando-os nos marcos da ordem capitalista vigente no país. Os dados mostram que, mesmo nos marcos da ordem capitalista, a luta pela valorização dos profissionais da educação básica é parte da luta do conjunto de trabalhadores. E mais, o magistério ainda precisa lutar para superar as mazelas do modelo federativo adotado como modelo de relação entre as três instâncias de poder que constituem a União. O federalismo brasileiro sustenta-se na autonomia dos entes federados e, ao mesmo tempo, na interdependência entre eles (ABRUCIO, 2006, p.92). 
O PSPN pode ser considerado como um avanço para a valorização dos professores porque, conforme bem afirmou Gramsci (1976, p. 87) que "o Estado é todo o conjunto de atividades teóricas e práticas com as quais a classe dirigente justifica e mantém não somente a sua dominação, mas também consegue obter o consenso ativo dos governados”. Assim, podese evidenciar nesse contexto político e jurídico de instituição do PSPN, a disputa dos docentes enquanto trabalhadores com os governos federal, estadual e municipal, em favor de uma política de valorização da profissão. E é nesse contexto que se insere a ação do Estado, por meio da Divape/Sase/MEC, de articulação e negociação com os entes federados para implementação da Lei 11.738/2008 em todo o país.

\subsection{A instituição do Piso Salarial Profissional Nacional (PSPN) como expressão política do Estado}

A instituição do PSPN, por meio da sanção da Lei 11.738/2008, consiste numa ação política implementada pelo Estado num tempo de relações democráticas e tensas com a sociedade brasileira, nos marcos da ordem capitalista vigente no país, sobretudo pela predominância das questões econômicas na política.

O Estado, sobretudo nos países periféricos do capitalismo, foca sua atuação nas relações e na regulação financeira. Assim, a gestão do Estado brasileiro nas suas relações democráticas com sociedade civil, especificamente no campo da educação, apresenta um projeto global, e outro projeto de operacionalização que consiste em um conjunto de planos setoriais, legislação e financiamento, por meio de Fundos para atender demandas sociais.

O estabelecimento do projeto global para a economia e do projeto operacional para a educação básica resulta das contradições de classes inseridas na sua própria estrutura. Assim, é necessário compreender o Estado como a condensação de uma relação de forças entre classes e frações de classes, tais como elas se expressam. Significa, pois, que "o Estado é constituído e dividido de lado a lado pelas contradições de classe" (POULANTZAS, 1985, p. 152). Portanto, a disputa política entre o Estado e as instituições que representam e defendem os interesses dos profissionais da educação em torno de uma política de valorização do magistério público configura-se como fundamental na garantia dos direitos assegurados na $\mathrm{CF}$ de 1988. 
A sociedade brasileira, como as demais sociedades capitalistas, caracteriza-secomo um lócus onde se confrontam a classe dos capitalistas e a classe dos trabalhadores assalariados e o Estado se configura como condensação da relação de disputa entre essas classes e as suas frações. Ou seja, a sociedade brasileira não é um espaço harmonioso e solidário, pois se caracteriza por um conflito estrutural que contrapõe grupos dominantes e dominados, exploradores e explorados, e não se concebe o Estado como um juiz neutro e acima dos interesses de classes. Sua atuação é determinada não por uma busca imparcial do bem-estar coletivo, mas sim pelo resultado de uma luta política, em que cada classe e frações de classe lutam para fazer prevalecer sua vontade e seus projetos, negando os das demais e buscando suprimi-los.

No caso específico da instituição do PSPN, considerado eixo da valorização dos profissionais da educação básica e suporte para uma educação pública de qualidade, a função do Estado consiste em implantar a Lei 11.738/2008 para atender aos interesses dos professores, mas, ao mesmo tempo, para alavancar o desenvolvimento econômico e social, em favor da manutenção da ordem capitalista vigente no país. Por isso, pode-se dizer que a promulgação da Lei 11.738/2008 não se configura como uma ação espontânea e neutra por parte do governo, mas, ao contrário, se impõe como uma ação política planejada e intencional ao sancionar a referida Lei: consiste na criação de um mecanismo legal para valorizar os profissionais da educação básica, mas, ao mesmo tempo, para sustentar a reproduzir o status quo numa economia capitalista periférica.

A conjuntura política do país propicia esse tipo de ação do Estado, levando-se em conta que a sociedade brasileira vive um tempo democrático e de aperfeiçoamento do ordenamento jurídico-institucional assegurado na CF de 1988. A sociedade brasileira hoje é regulada pela ordem capitalista, mas vive tempos de democracia, possibilitando maior participação da sociedade civil nas coisas do Estado. Assim, na perspectiva do Estado, a valorização dos profissionais da educação básica se insere nesse processo de aperfeiçoamento da gestão democrática do Estado, materializada na sanção da Lei 11.738/2008. Em outros termos, a instituição do PSPN dentro da ordem capitalista vigente no país, busca valorizar os professores da educação básica.

A a intenção do Estado, de fato, consiste sobretudo em aumentar os salários dos professores, para que possam comprar produtos em forma de mercadorias nos mercados de consumo e, assim, são valorizados como trabalhadores e cidadãos. Esse é o sentido de valorização dado ao PSPN e proclamado em discursos afirmativos dos órgãos do Estado, dos 
entes federados, das entidades e movimentos de classe que representam os interesses dos profissionais da educação básica, e até mesmo dos próprios professores.

A ação política do Estado de valorizar os professores da educação básica por meio da instituição do PSPN, sob a gestão da Sase/MEC, agrega três elementos considerados básicos na CF de 1988, na LDB e na Lei 11.738/2008, ou seja, piso salarial, formação profissional e plano de carreira, sendo o primeiro considerado o principal. A articulação desses elementos tem um só objetivo: aumentar o poder econômico-financeiro dos professores, para que possam comprar e consumir mais mercadorias nos mercados. Enfim, a visão do Estado sobre a valorização dos profissionais da educação básica consiste, sobretudo, em promovê-los e incentivá-los a consumir para alavancar a força do capital no país, confirmando que a função do Estado brasileiro não é a de um juiz neutro e acima dos interesses de classes. O discurso governamental vai no sentido de que as medidas, as políticas, os projetos e as ações implementadas sejam para beneficiar a todos os trabalhadores da Educação no país, mas ocultam o objetivo maior do Estado que é o de implementar políticas que garantam a manutenção da estrutura de classes nas sociedades no país, em benefício da classe dominante hegemônica. Daí porque o governo afirma ser a implementação do PSPN relevante na valorização dos professores sob a gestão democrática do Estado.

Nessa lógica, a instituição do PSPN expressa a inserção de mais um mecanismo no sistema capitalista, confirmando o fato de que todas as ações políticas, sociais, econômicas, culturais, ambientais, educacionais, jurídicas desveladas ou veladas, explícitas ou ocultas, que ocorrem nos marcos da ordem capitalista, efetivamente, são por ela absorvidas. A instituição do PSPN não foge à essa ordem, não ocorre à margem ou fora dela, mas é parte constitutiva do sistema e alimenta o próprio sistema.

Desse modo, a ação política do Estado ao implementar o PSPN impacta, necessariamente, no trabalho educativo realizado pelos professores nas escolas, considerado diferente de outros trabalhadores na sociedade brasileira. Saviani (1997, p. 17) ressalta que

\footnotetext{
O trabalho educativo é o ato de produzir, direta e indiretamente, em cada indivíduo singular, a humanidade que é produzida histórica e coletivamente pelo conjunto dos homens. Assim, o objeto da educação diz respeito, de um lado, à identificação dos elementos culturais que precisam ser assimilados pelos indivíduos da espécie humana para que eles se tornem humanos e, de outro lado e concomitantemente, à descoberta das formas mais adequadas para atingir esse objetivo.
}

Nesse conceito de trabalho educativo formulado por Saviani identifica-se uma perspectiva que supera a opção entre a essência humana abstrata e a existência empírica. A essência abstrata é recusada na medida em que as forças essenciais humanas nada mais 
são do que a cultura humana objetiva e socialmente existente, o produto da atividade histórica dos seres humanos. Produzir nos indivíduos singulares "a humanidade que é produzida histórica e coletivamernte pelo conjunto dos homens" (SAVIANI, 1977, p. 17) significa produzir a apropriação pelos indivíduos, das forças essenciais humanas objetivadas historicamente.

Esse conceito de trabalho educativo também supera a concepção de educação guiada pela essência e abstração e reafirma a existência empírica, na medida em que sua referência para a educação é a formação do indivíduo enquanto membro do gênero humano. Ao adotar tal referência, esse conceito de trabalho educativo estabelece como um dos valores fundamentais da educação o do desenvolvimento do indivíduo para além dos limites impostos pela divisão social do trabalho.

Assim, pode-se dizer que o trabalho desenvolvido pelos professores da educação básica é uma atividade intencional dirigida por fins. Daí diferenciar-se de formas espontâneas de educação, ocorridas em outras atividades, também dirigidas por fins, mas que não são de produzir a humanidade no indivíduo. Quando isso ocorre, nessas atividades, trata-se de um resultado indireto e não intencional. Portanto, a produção no ato educativo é direta em dois sentidos. O primeiro é o de que se trata de uma relação direta entre educador e educando. O segundo é relativo à educação, à humanização do indivíduo, é o resultado mais direto do trabalho educativo. Outros tipos de resultados podem existir, mas serão indiretos e complementares.

Mediante à essa concepção de trabalho educativo de Saviani (1977), o que dizer da ação política do Estado brasileiro ao instituir o PSPN, com o intuito de valorizar os professores da educação básica?

Pode-se dizer que a instituição do PSPN veio confirmar a função do Estado brasileiro em fortalecer os interesses da classe dominante no país. Nesse sentido, a concepção de trabalho educativo apresentada por Saviani não se harmoniza com o objetivo do Estado ao promulgar a Lei 11.738/2008, uma vez que sua intenção real e concreta não é a de valorizar o trabalho educativo dos professores, mas fortalecer a ordem capitalista vigente no país, por meio criação de leis que alavancam a referida ordem. As leis são consideradas como aparatos jurídicos do Estado para legitimar a força do capital e apaziguar os conflitos existentes. Por isso são considerados aparatos ideológicos e de alienação na ação do Estado, para escamotear ou ocultar os seus 
interesses e fazer parecer que as demandas dos trabalhadores da Educação são também seus interesses.

Por outro lado, a instituição do PSPN expressa o rsultado da luta dos professores em busca da valorização do trabalho que realizam nas escolas. Essa luta não se encerrou, pois a instituição do PSPN valoriza os professores do ponto de vista econômico e financeiro, mas não leva em conta a potencialidade do trabalho educativo que realizam nas escolas e nem os valoriza como deveria enquanto humanos em suas múltiplas dimensões. Assim, pode-se dizer que a instituição do PSPN dá-se em um espaço político em luta, pois, levando-se em conta a perspectiva gramsciana (1999), ela não pode ser explicada somente em termos de um determinismo econômico mecanicista; é necessário mostrar a importância dos fatores políticos, morais, culturais e ideológicos que a envolvem.

A luta de classe existente na sociedade brasileira se traduz, em menor proporção, nas ações do Estado em favor da valorização dos professores da educação básica, e a instituição do PSPN é o resultado de um conflito político em que os professores lutam para fazer prevalecer seus interesses e objetivos na construção do Estado democrático no país contra a hegemonia dos interesses da classe dominante. 


\title{
CAPÍTULO 2 - A instituição da Lei 11.738/2008, valorização e plano de carreira sob a visão dos gestores educacionais federais e municipais e dirigentes de entidade nacional e sindicais municipais de professores da educação básica pública
}

\begin{abstract}
Como o sentido de valorização dos professores na instituição do piso salarial profissional se mostra positivo na visão dos gestores educacionais e dirigentes de entidade nacional e sindicais municipais e, ao mesmo tempo, tal positividade pode servir para esconder a simplificação da potencialidade do trabalho docente nas escolas públicas?
\end{abstract}

Este segundo capítulo analisa a instituição do PSPN na visão dos gestores educacionais federais e municipais, e dirigentes de entidade nacional e sindicais municipais de professores da educação básica, à luz das categorias analítico-filosóficas ideologia e alienação, para desvelar o quanto a valorização dos professores do magistério público da educação básica focada no elemento econômico e financeiro minimiza a potencialidade do trabalho educativo realizado pelos professores, em três blocos: Bloco A - gestores educacionais federais; Bloco B - gestores educacionais municipais; Bloco C - dirigentes de entidade nacional e sindicais municipais de professores. Cada bloco é formado de três eixos e cada eixo é constituido por duas ou três questões, assim ordenados:

Eixo 1 - Envolvimento, experiências e ações no processo de instituição do Piso Salarial Profissional Nacional. Questiona-se como a ideologia e a alienação se expressam no envolvimento, nas experiências e ações dos gestores federais e municipais e dirigentes de entidade nacional e sindicais municipais em favor da valorização dos professores da educação básica, por meio da instituição do Piso Salarial Profissional Nacional?

Eixo 2 - Valorização por meio da instituição do Piso Salarial Profissional Nacional. Questiona-se: como vem sendo negociada a implantação do PSPNl após a sanção da Lei 11.738/2008? Como se configuram as principais dificuldades que obstaculizam a instituição do PSPN? Como a instituição do PSPN valoriza os professores nos entes federados?

Eixo 3 - Implantação dos planos de carreira. Questiona-se: como vem sendo negociada pelo governo a implantação dos planos de carreira dos professores nos entes federados? Como os planos estruturam a carreira? Como as ações dentro dos planos de carreira valorizam os professores?

Nessa linha de ordenamento, o capítulo se estrutura em três partes que se complementam. A primeira analisa os mecanismos ideológicos e de alienação que na ação do Estado em favor da valorização dos professores da educação básica por meio da instituição do 
PSPN; a segunda analisa o processo de desumanização no trabalho o no trabalho docente no contexto da ordem capitalista; na tereira faz-se uma análise das visões dos gestores federais e municipais e dirigentes de entidade nacional e sindicais municipais sobre a instituição do PSPN, à luz das categorias marxianas de ideologia e alienação.

\title{
2.1 Ideologia e alienação: o sentido da ação política do Estado em favor da valorização dos professores nos marcos da ordem capitalista vigente no país
}

\begin{abstract}
O trabalhador se torna tanto mais pobre quanto mais riqueza produz, quanto mais a sua produção aumenta em poder e extensão. O trabalhador se torna uma mercadoria tão mais barata quanto mais mercadorias criam. Com a valorização do mundo das coisas aumenta em proporção direta a desvalorização do mundo dos homems. $\mathrm{O}$ trabalho não produz somente mercadorias; ele produz a si mesmo e ao trabalhador como mercadoria, e isto na medida em que produz, de fato, mercadorias em geral. Este fato nada mais exprime, senão: o objeto que o trabalho produz, o seu produto, se lhe defronta com um ser estranho, como um poder independente do produtor. $\mathrm{O}$ produto do trabalho é o trabalho que se ficou num objeto, fez-se coisa, é a objetivação do trabalho [...] a objetivação como alienação. (MARX, 2002).
\end{abstract}

Etimologiamente, a palavra "alienação" vem do latim alienare, alienas, que significa "algo que pertence a outro". E outro é "alius". Assim, alienar é tornar alheio, transferir para outrem o que é seu. Na linguagem filosófica contemporânea, alienação é o "estado do indivíduo que não mais se pertence, que não detém o controle de si mesmo ou que se vê privado de seus direitos fundamentais, passando a ser considerado como uma coisa" (JAPIASSU; MARCONDES, 2001, p.10).

Em Hegel, o conceito de alienação é positivo ao analisar a função do trabalho, na célebre passagem do "senhor do escravo", descrita em Fenomelogia do Espírito. Hegel (1992) se refere a dois homens que lutam entre si, e um deles sai vencedor, podendo matar o vencido; este, não ousando sacrificar sua própria vida, se submete. Ao vencedor convém conservar o outro como servo, pois esta é a condição de ser reconhecido como senhor. Agora é o servo submetido que tudo faz para o senhor; este, com o tempo, descobre que não sabe fazer mais nada, pois colocou, entre si e o mundo, o escravo, que domina a natureza. O ser do senhor se descobre como dependente do ser do escravo e, em compensação, o escravo, aprendendo a vencer a natureza, recupera de certa forma a liberdade. $O$ trabalho surge, então, como a expressão da liberdade reconquistada.

Marx, por sua vez, retoma a temática hegeliana, mas critica essa visão idealista do trabalho. Na obra Manuscritos econômicos e filosóficos, Marx emprega o conceito de 
alienação em dois sentidos principais: no primeiro sentido, o trabalhador era alienado porque, de certa forma, estava "alheio ao produto final do seu trabalho" (MARX, 2008, p. 82). MarX parece estar fazendo uma contraposição entre o processo de produção artesanal e o industrial. No processo artesanal, o trabalhador detinha a posse do produto feito, o consumia ou usava como moeda de troca, ou seja, ele lhe pertencia. Mas, com a Revolução Industrial, tem-se o início do processo de alienação, pois o produto final não pertence mais ao produtor, ao trabalhador, mas, sim, ao seu patrão, ou seja, o produto final lhe é expropriado. A propriedade do produto pertence a outro (alius), é externa.

Em um segundo sentido relacionado à alienação, Marx afirma que o novo regime trabalhista imposto pela indústria também "aliena o homem de si mesmo". (MARX, 2008, p. 84). Dessa forma, Marx parece alertar para o fato de que esse novo sistema de produção (industrial) tende a converter o trabalhador em uma engrenagem de uma máquina, parece furtar-lhe a humanidade, a sua condição humana, pois agora, em seu trabalho, não há espaço para a invenção, a criatividade, esse regime de trabalho o obriga a realizar movimentos repetitivos, mecânicos. O indivíduo, de certa forma, se torna parte da máquina, ele não precisa mais pensar, refletir acerca do que constrói, apenas realiza determinados movimentos. O ser humano é reduzido a gestos mecânicos.

Assim, para Marx (2008), ao privilegiar a consciência, Hegel perde a materialidade do trabalho. O trabalho é a condição da liberdade humana; o ponto central do seu pensamento filosófico. Por isso o conceito supremo de toda a sua concepção humanista está em que o ser humano deve trabalhar para si na relação com os outros em sociedade, isto é, deve trabalhar para fazer-se a si mesmo. Mas, em decorrência da Revolução Industrial, o trabalho alienado o desumaniza.

Desse modo, Marx (2008), ao contrário de Hegel, considera que alienação está ligada à necessidade que o homem tem de recorrer à natureza para se tornar um ser social. Ele acredita que a alienação é uma realidade histórica universal profunda, tanto que chega a considerar a História como sendo nada mais nada menos do que a história da alienação humana.

Marx (2008) analisa tipos de alienação do ser humano pelo ser humano, mas considera o trabalho como o principal instrumento dessa alienação, pois aliena o ser humano do produto do trabalho e de seu caráter genérico. Em sua análise, o primeiro tipo de alienação citado por Marx é a religiosa. Para ele, a religião oferece ao ser humano uma ilusão capaz de ajudá-lo a suportar a crueldade da vida material, substituindo as condições da vida por uma 
explicação fantasiosa. Assim, a base de sua crítica religiosa está na idéia de que o ser humano faz a religião e não a religião faz o ser humano.

No campo político, Marx (2008) considera que os seres humanos formam os grupos, as sociedades e o Estado, para que seus direitos e bens sejam garantidos. Entretanto, geralmente, esses grupos assumem uma postura independente e autônoma e se revoltam contra o ser humano, privando-o de seus direitos e mesmo de seus bens. Essa postura, de acordo com Marx, é usada geralmente como um mecanismo da classe dominante hegemônica do Estado para manter o seu poder sobre outra classe e demais frações sociais.

Para Marx (2008), embora a alienação religiosa e a alienação política sejam relevantes, a alienação econômica é considerada a principal por ser a base de todas as demais, na medida em que tem origem na propriedade privada dos meios de produção. Destaca que o trabalhador nunca recebe o valor integral do produto do seu trabalho. E, desse modo, ele sempre entra numa relação de prejuízo com o capitalista proprietário dos meios de produção e fornecedor de empregos e de misérias.

$\mathrm{Na}$ visão de Marx no sistema capitalista o trabalho assume seu lado negativo de forma mais contundente, torna-se atividade estranha, alienada:

\footnotetext{
A tal ponto aparece a realização do trabalho como desrealização do trabalhador, que este é desrealizado até chegar a morrer de fome. A objetivação aparece a tal ponto como perda do objeto que o trabalhador se vê privado dos objetos mais necessários não somente para a vida, mas inclusive para o trabalho. Mais do que isso, o próprio trabalho converte-se num objeto do qual o trabalhador só pode se apoderar com o maior esforço e com as mais extraordinárias interrupções. A apropriação do objeto aparece em tal medida como alienação, que quanto mais objetos produz o trabalhador, tanto menos consegue possuir e tanto mais submetido fica à dominação de seu produto, quer dizer, do capital. (MARX, 1985, p. 106).
}

Ao analisar o lado negativo do trabalho, Marx (1985) destaca, ainda, que é justamente por estar em condição de ser humano expropriado dos meios de produção, que durante toda vida o trabalhador se vê obrigado e condicionado a engajar-se em um luta contínua pela manutenção de suas necessidades físíco-corpóreas básicas e, uma vez despossuído dos meios próprios de produção, luta para manter-se empregado para alguém que é dono dos meios de produção. Marx ressalta que o trabalhador, despojado de meios de produção, tende a ser subsumido no interior da ordenação social do sistema capitalista. Isso tanto nos períodos de grande prosperidade social, como nos períodos de estabilidade e principalmente nos períodos de crises econômicas. Assim, o capitalismo implica na exploração do trabalhador, pois todo movimento da produção capitalista consiste em tornar maximamente produtivo o trabalho do trabalhador e em manter o mais baixo possível a retribuição do salário. 
Em Manuscritos Econômicos Filosóficos ou Manuscritos de Paris, que consiste numa série de anotações que formam uma coletânea de três cadernos divididos em pesquenos ensaios, Marx (2008) parte de uma análise filosófica que marca o desenvolvimento do seu primeiro confronto com a economia política vigente em seu tempo. Nas reflexões 57 e 58 dos Manuscritos de Paris, realiza a primeira formulação concreta da especificidade da alienação na sociedade burguesa - o problema do fetichismo. A definição teórico-analítica desta dimensão particular da categoria de alienação ocorre em função da análise do conjunto de mediações histórico-concretas responsáveis pela afirmação do valor de troca como forma determinante de intercâmbio econômico-social e de interação sociocultural da sociedade burguesa.

Japiassu e Marcondes reafirmam que a ideia de alienação tem raízes na crítica à filosofia hegeliana que, numa perspectiva idealista, a considera positiva no trabalho e na consciência do ser humano.

Ao contrário do pensamento hegeliano, Marx concebe a alienação como negativa no trabalho humano e a subverte numa perspectiva histórica, materialista e dialética, significando despossessão, seguida da ideia de escravidão. Por isso quando Marx afirma que o trabalho é um instrumento de alienação na economia capitalista, considera que o trabalhador é despossuído do fruto do seu trabalho. Daí a alienação ser um problema ameaçador do trabalho e da consciência humana desde seus primórdios, mas afetando principalmente o trabalhador no mundo moderno, no qual as relações sociais se tornaram cada vez mais determinadas por seu aspecto mercantil, econômico-financeiro, capitalista. (JAPIASSU e MARCONDES, 2001, p. 10).

Japiassu e Marcondes (2001) afirmam, ainda, que para Marx a alienação é negativa porque decorre da situação econômica de dependência do trabalhador em relação ao capitalista, na qual vende sua força de trabalho como mercadoria, tornando-se escravo. Para Marx, a propriedade privada, com a divisão do trabalho que institui, pretende satisfazer o ser humano em suas necessidades básicas. Na realidade, ao separá-lo de seu trabalho e ao privá-lo do produto de seu trabalho, ela o leva a perder a sua essência, projetando-a em outrem, em Deus, por exemplo. A perda da essência humana atinge o conjunto do mundo humano. As alienações religiosas, políticas, jurídicas, filosóficas, educacionais são geradas pela alienação econômica. De modo particular, a alienação política é exercida pelo Estado, instrumento da classe dominante hegemônica que submete os trabalhadores aos seus interesses. A alienação religiosa é aquela que impede o ser humano de reconhecer-se como sujeito de sua própria história, acreditando que a sua existência e de outros seres humanos depende de um Ser 
Transcendental. Assim, ela amortece e esconde a essência do ser humano, remetendo-a ao poder de uma divindade (JAPIASSU; MARCONDES, 2001, p. 10).

Com a mesma postura crítica com que analisa a alienação, Marx aborda a ideologia. Na obra A Ideologia Alemã, Marx e Engels (1977) definiram o conceito de ideologia a partir do qual operaram parte de suas reflexões teóricas. Esse conceito foi revisto posteriormente por eles mesmos e por outros pensadores marxistas, entre eles Antonio Gramsci. Seu elemento constitutivo principal foi o de que ambos denominaram a ideologia como princípio da inversão, expressando a ideia de inversão da realidade.

No entendimento de Marx e Engels (1977), a ideologia é um fenômeno de superestrutura, uma forma de pensamento opaco, que impede de revelar as causas reais de certos valores, concepções e práticas sociais que são materiais, sobretudo econômicas, contribuindo para sua aceitação e reprodução, representando um mundo invertido a serviço dos interesses da classe dominante, os quais aparecem como se fossem interesesse da sociedade em sua totalidade. Em uma das passagens do livro, eles sustentaram que o sistema de ideias de uma classe dominante configura o conjunto das ideias dominantes em cada época:

\begin{abstract}
A produção das ideias, das representações, da consciência é [...] diretamente entrelaçada com atividade material e com as relações dos homens. [...] Se na ideologia os homens e as suas relações aparecem de cabeça para baixo, como numa câmara escura, esse fenômeno deriva-se do processo histórico de suas vidas. [...] Os pensamentos dominantes são a expressão ideológica das relações materiais dominantes concebidas sob a forma de pensamentos. (MARX; ENGELS, 1977, p. 125).
\end{abstract}

Esse sistema de ideias dominantes constitui, assim, a ideologia. De acordo com uma imagem metafórica construída por Marx e Engels (1977), a ideologia teria a faculdade de fazer com que a vida social aparecesse para os seres humanos como uma imagem que é exibida pelo visor de uma câmera fotográfica do final do século XIX, ou seja, de cabeça para baixo, ilusoriamente invertida do sentido que ela apresentaria na realidade. Dessa forma, ela ofereceria para a sociedade uma imagem inversa do que ela própria seria e viveria no âmbito real. Essa falsa imagem levaria o homem e a sociedade a uma falsa consciência acerca de si mesmo e das relações concretas estabelecidas.

Marx e Engels (1977) objetivaram demonstrar o papel de véu desempenhado pela ideologia burguesa na sociedade capitalista, qual seja o de ocultar a verdadeira natureza das relações de produção pautadas na dominação e exploração. Assim, quanto mais se desenvolvessem os antagonismos entre as forças produtivas em crescimento, mais a ideologia 
da classe dominante seria penetrada pela hipocrisia, e quanto mais a vida desvendasse a natureza mentirosa dessa ideologia, mais a linguagem dessa classe se faria sublime e virtuosa.

No entendimento de Marx e Engels (1977), a solução para desvelar a ideologia da classe dominante estaria no conhecimento científico, ou saber real, único elemento capaz de desmascarar a ideologia burguesa, recolocando de volta o mundo de cabeça para cima, de acordo com seu sentido real, mostrando a realidade tal como ela é, destituída dos véus da ideoloiga. Esse saber real constituiria um conjunto de verdades capaz de desmascarar a falsa consciência, funcionando como ponta-de-lança na luta do proletariado contra a burguesia. A concepção marxista de ciência também é considerada instrumental, à medida em que estaria rm favor das maiorias, da causa proletária e da revolução socialista.

Assim, pode-se afirmar que no pensamento marxiano a ideologia consiste num conjunto de ideias que dissimulam a realidade, porque mostram as coisas de forma parcial ou distorcida em comparação ao que realmente são. Na realidade, o que se busca ocultar ou dissimular é o domínio da classe dominante sobre a classe oprimida na sociedade capitalista. Nessa linha de raciocínio, Chauí afirma:

A ideologia precisa das ideias e das imagens, da inversão de causas e efeitos, do
silêncio para manifestar os interesses da classe dominante e escondê-los como
interesse de uma única classe social. A ideologia não é o resultado de uma
vontade deliberada de uma classe social para enganar a sociedade, mas é efeito
necessário da existência social da exploração e, assim, então é a interpretação
imaginária da sociedade do ponto de vista de uma única classe. (CHAUÍ, 1997,
p. 176)

Tendo como subsídios as concepções marxianas de alienação e ideologia, reconfirmadas por Japiassu e Marcondes e Chauí, busca-se analisar o sentido da ação política do Estado em favor da valorização dos professores da educação básica, por meio da instituição do PSPN, nos marcos da ordem capitalista vigente no país.

A ação política do Estado, focada na instituição do piso salarial profissional, visando valorizar os professores da educação básica, caracteriza-se como uma ação carregada de contradições as quais precisam ser explicitadas.

De pronto, ressalta-se que o sentido de valorização que fundamenta e norteia a ação do Estado ao instituir o PSPN é positivo por expressar a intenção de valorizar os professores da educação básica. Entretanto, tal positividade restringe-se em aumentar o salário dos docentes, que é o meio de empoderá-los econômica e financeiramente, para que possam comprar mercadorias necessárias à sua sobrevivência. A ação do Estado 
valoriza o salário, mas minimiza a potencialidade do trabalho realizado pelos professores. Sobre esse tipo de ação, Marx e Engels afirmam:

[...] para oprimir uma classe é preciso ao menos garantir-lhe as condições mínimas que lhe permitam ir arrastando a existência servil. Assim, à esta categoria é garantido um salário reduzido que atende apenas as necessidades mínimas de sobrevivência física e não social, cultural, humana. O professor, portanto, passa a enxergar no outro ser humano um concorrente, desafeto, inimigo e opressor. O professor não se reconhece no outro trabalhador professor. (MARX e ENGELS, 2002, p. 46).

Assim, a instituição do piso salarial restinge-se em atender algumas necessidades fisiológicas básicas dos professores tais como comer e beber, vestir-se, morar e procriar, embora esse não seja o tom dos discursos oficiais proclamados pelos dirigentes e gestores governamentais. Em geral, os discursos e práticas oficiais ocultam esse sentido da instituição do PSPN, ressaltando que a ação do Estado pautada na CF de 1988, a LDB de 1996, na Lei do Fundef, na Lei do Fundeb e na Lei 11.738/2008 é democrática e emancipadora para os professores.

Desse modo, pode-se dizer que a ação do Estado ao instituir o PSPN mecanismo que inimiza o sentido real de valorização dos docentes, que é o trabalho que realizam nas escolas como categoria fundamentalmente do ser humano. Em decorrência, os professores são submetidos à situações nefastas como o distanciamento das condições autônomas de trabalho, a intensificação das tarefas e sistemas de avaliação centralizados, resultando num processo de estranhamento, alienação no trabalho realizado, seja na dimensão do produto, do processo de trabalho, de si mesmos e dos outros professores. Além disso, são alienados na sua relação com o conhecimento por eles transmitidos na aprendizagem e no trabalho controlado externamente, por meio da perda do poder de decisão dos meios, do objeto e dos processos em si. Eles tendem a não se reconherem em suas atividades e em si mesmos. O trabalho docente que realizam nas escolas e em outros espaços educacionais deixa de ser um ato prazeiroso de realização humana, de transformação de si mesmos, dos outros e do meio que os cerca, para ser uma ação necrófila, enfadonha, que mortifica, cansa, aliena, sacrifica os professores, alheia a si mesmos e satisfazer apenas, e às vezes precariamente, as suas necessidades físicas, negando a sua sociabilidade e humanidade em qualquer espaço de trabalho. 


\subsection{Trabalho e trabalho docente: processos de desumanização}

Nos marcos da ordem econômica vigente no país, a ação do Estado ao instituir o PSPN, por um lado, contibui para o fortalecimento do mercado capitalista, visando aumentar a quantidade de dinheiro pago aos professores pelo seu trabalho e garantia de sobrevivência. A referência da ação promovida pelo Estado é o mercado e não o trabalho dos professores. A intenção do Estado é criar condições mínimas aos professores, por meio da valorização salarial, para que possam comprar e consumir mercadorias, essencialmente, aquelas necessárias à sua sobrevivência, contribuindo assim para o fortalecimento da ideologia do sistema capitalista, que é uma forma social, teoricamente, baseada na liberdade individual e na livre inciativa.

Numa visão crítica à ação do Estado ao instituir o PSPN nessa forma social, ressalta-se que não se trata de uma forma social basedada na liberdade, pois, na prática, ela existe apenas sob o aspecto formal e não substancial, ou seja, existe teoricamente, mas não na realidade. É bem verdade que as revoluções burguesas, que marcaram a consolidação do capitalismo, têm como princípio a liberdade e igualdade de todos os seres humanos perante a lei, porém, na prática, as sociedades capitalistas não são espaços nos quais os seres humanos vivem livremente, mas espaços de opressão e violência em decorrência do conflito estrutural entre proprietários capitalistas e os trabalhadores assalariados. Nesses espaços a relação entre classes é essencialmente de contradição e exploração, pois são marcados pela acumulação de riqueza nas mãos de poucos em detrimnento da maioria.

Em sua análise crítica às contradições existentes no sistema capitalista, Marx aborda a questão da exploração do trabalho por meio do pagamento de salário ao tabalhador. No texto Manuscritos Econômicos Filosóficos (2008), ele demonstra que o salário pago ao trabalhador, em verdade, é parte do próprio produto. O trabalho representa um incremento periódico do capital, por meio da mais-valia, tornando-se um meio para o processo de valorização.

Os homens, para sobreviver, precisam trabalhar e, popr meio do trabalho, entram no sistema capitalista, tendo que receber um salário baixo para se sustentar e sustentar suas famílias, sem lucro algum no salário que recebem. Então, os homens transformam-se em mercadorias para os capitalistas, tendo que vender sua força de trabalho pelo preço que os capitalistas impõem, sem poder escolher, pois correm o risco de perder seus postos para outros trabalhadores que também seencontram na mesma situação. Com isso os capitalistas impõem ao trabalhador um só emprego om salários baixos, criando um círculo vicioso no 
qual o trabalhador vende sua força de trabalho (mercadoria) para comprar mercadorias necessárias à sua sobrevivência.

De fato, o trabalhador troca sua força de trabalho por dinheiro e, desse modo, sua vida acaba sendo trocada pela sobrevivência, pois ao vender a sua força de trabalho precisa consumir, e para consumir precisa vender sua força de trabalho. A partir dessa situação, o ser humano trabalhador deixa de ser ele mesmo e passa a ser o que os capitalistas querem que ele seja transformado num ser alienado, sem perceber que sua força de trabalho vendida é alienante. Nessa relação de exploração, o capitalista arranca do ser humano o livre arbítrio, pois ao vender a sua força de trabalho, passa a viver sob a dominação do capitalista, aliena-se.

$\mathrm{Na}$ ideologia capitalista, o poder do dono do capital tem que se sobrepor à vida do trabalhador. Segundo Marx

O trabalhador não ganha necessariamente quando o capital ganha, mas perde forçosamente com ele. Assim, o trabalhador não ganha se o capitalista consegue manter o preço corrente acima do preço natural pro meio de um segredo industrial ou comercial, de um monopólio ou de uma situação favorável da sua propriedade. (MARX, 2002, p. 66),

No entendimento de Marx, o fundo de reserva de capital deve exaurir-se, em função da necessidade do capitalista de consumir mercadorias. Se tal reserva não se esgota, é porque o trabalho acrescenta um fruto anual no capital, o qual pode então ser consumido, sem que o capitalista se torne pobre. O trabalhador produz, além disso, o fundo do qual se retira seu pagamento, já que não recebe depois que o valor de sua força de trabalho é realizado em mercadoria e mais-valia. Portanto, o salário é uma parte do produto, reproduzido pelo próprio trabalhador e não um pagamento com recursos do capital. Por conseguinte, de um lado, a alienação é o ponto de partida do processo de produção, pois nela se dá a separação entre o trabalho e seu produto, entre as condições objetivas e a força subjetiva da criação de valor. Por outro lado, também é o resultado da produção, na medida em que esse ponto de partida acaba produzindo-se e reproduzindo-se permanentemente, eternizando-se como consequência da produção capitalista.

A explicação de Marx não se limita apenas à distribuição de renda, à exploração econômica ou à apropriação do produto do trabalho pelo capitalista. Mas vai além, ao abordar o trabalho relacionando-o com o desenvolvimento pleno das capacidades humanas. Marx (2002) entende que o trabalho é a vida genérica ativa humana, na medida em que permite construir o mundo objetivo em que o homem vive, no qual há uma influência recíproca entre todos. Com isso, ele condena o trabalho no contexto moderno ocidental, baseado na 
determinação e na especialização. Esse trabalho, como categoria da economia política, é justamente o que dificulta a realização das potencialidades humanas, obrigando o trabalhador a restringir seus horizontes a um mínimo de atividades que o permitem continuar existindo e, ao mesmo tempo, restringe e limita a sua própria vida. É, assim, não somente uma mutilação intelectual e moral, mas também um obstáculo ao ato de criação humana, ao desenvolvimento da consciência do indivíduo.

Na compreensão de Hungaro (2002), o ser humano vive numa situação de constante tensão entre sua dupla dimensão: individualidade e generalidade. A percepção de sua singularidade deve-se ao processo revolucionário empreendido pela burguesia. Esta, ao derrubar a ordem feudal, criou as condições para que os homens se percebessem como seres singulares, porém essa percepção coloca o indivíduo em conflito com o seu ser genérico.

Hungaro afirma que:

Os seres humanos são constituídos por essa singularidade imediata, mas só é possível de ser transcendida na adequação ao desenvolvimento genérico. Em decorrência da alienação, essa singularidade imediata fica carecida de mediações e, de tal forma, que aparece como uma singularidade dada ("natural"), espontânea. Assim, de acordo com a elaboração marxiana, não nos percebemos como indivíduo social, não nos percebemos ligados a toda referência cultural de nossos horizontes histórico-sociais. A consequência disso é nefasta, pois se há hipertrofia da singularidade, o gênero acaba por empobrecer. (HUNGARO, 2014, p. 42)

E o autor reafirma que a contradição entre indivíduo e gênero deve-se, portanto, à uma estruturação da sociedade civil em torno da propriedade privada. Ela transforma os seres humanos em unilaterais e tornou a sua atividade produtiva emancipatória, o trabalho, um meio de subsistência. Tornam-se assim empobrecidos tanto em sua singularidade quanto em termos de gênero. (HUNGARO, 2014, P. 42).

No contexto específico do pagamento do Piso Salarial Profissional Nacional, pode-se dizer que a Lei 11.738/2008 consiste numa ação do Estado de empoderamento econômico e financeiro dos professores, para contribuir no fortalecimento do mercado de consumo e camuflar a sua real intenção, que é de minimizar a singularidade do professor, empobrecendoos como seres humanos. Nas palavras de Marx,

[...] o aumento de salário não passa de uma remuneração melhor de escravos, pois não representa a restauração do significado e valor humanos do trabalho e do trabalhador. O sistema de salários, na medida em que remunera o trabalhador, é uma consequência necessária da alienação do trabalho. Do mesmo modo, a igualdade de renda não modifica a relação do trabalhador com o seu trabalho, somente torna a sociedade uma espécie de capitalista abstrato. (MARX, 1996, p. 120) 
O sentido da ação do Estado em valorizar o salário dos professores insere-se na totalidade do trabalho na sociedade capitalista e, como tal, embora não apareça de imediato, configura-se como um mecanismo de minimização da singularidade dos professores. Esse mecanismo dá-se no próprio trabalho desenvolvido pelos professores nas escolas.

$\mathrm{Na}$ sociedade brasileira, assim como nas demais sociedades capitalistas, as relações contratuais, formais, próprias da urbanização e industrialização, exigem níveis mínimos de abstração por parte dos indivíduos, para sua inserção social. Por isso a educação escolar que é oferecida à população vai se universalizando, mas de forma ambígua, pois ao mesmo tempo em que o ensino é direito de todos, também se determina a desqualificação deste saber, não oportunizando a apropriação do conhecimento científico para todos. No entendimento de Saviani,

a tendência dominante desta sociedade é a de considerar a educação não como apropriação da ciência, mas sim como marco decisivo para o desenvolvimento econômico. [...] Ela deixa de ser pensada no âmbito intelectual, de formação humana, de caráter improdutivo, para um caráter de qualificação da mão-de-obra como força de trabalho. Por isso, a educação se torna funcional e de interesse ao sistema capitalista. É uma educação voltada às necessidades de formação para o trabalho. (SAVIANI, 1994, p. 130).

A afirmação de Saviani explicita a razão pela qual a educação escolar volta-se às necessidades de formação para o trabalho na sociedade capitalista, sustentada no ideário liberal de dominação, que supera as antigas formas de dominação de um ser humano por outro, seja pela escravidão na antiguidade ou pela servidão no período medieval. $\mathrm{O}$ ideário neoliberal postutal que as sociedades modernas são democráticas e formadas por indivíduos livres e iguais, com as mesmas condições de luta pela produção de sua existência. Entretanto, tal afirmação serve apenas para escamotear a realidade, na medida em que o que se percebe é que a continuidade de um modelo de sociedade no qual permanecem as desigualdades, as riquezas socialmente produzidas estão concentradas nas mãos de uma minoria de indivíduos, enquanto a maioria vive em condições precárias de existência e exclusão social.

Frigotto (2003, p. 65 ) reforça o argumento de Saviani, afirmando:

Ao contrário do que postula o ideário liberal clássico, o longo processo de passagem do feudalismo para o sistema capitalista não representou a superação de uma sociedade marcada pela opressão, servilismo e desigualdade de classes por uma sociedade livre e igualitária. A superação do sevilismo e da escravidão não foram pressupostos para a abolição da sociedade classista, mas condição necessária para que a nova sociedade capitalista pudesse, sob uma igualdade jurídica, formal e, portanto, legal, inaugurar as bases das relações econômicas, políticas e ideológicas de uma nova sociedade de classes. (FRIGOTTO, 2003, p. 65). 
Daí a relevância dada à educação escolar, na medida em os professores, em geral, se empenham de corpo e alma para oferecer e assegurar a aquisição de conhecimentos a todos os cidadãos, conhecimentos estes que, evidentemente, visam atender aos interesses das classes trabalhadoras, mas, ao mesmo tempo, às exigências e interesses do sistema do capital. Assim, o trabalho dos professores se organiza em função das necessidades produtivas e sociais. Segundo Kuenzer e Caldas (2009), o trabalho docente insere-se na totalidade do trabalho no capitalismo, permeado por suas contradições, e marcado pela ocultação da desumanização e do sofrimento do professor.

A inserção do trabalho docente na totalidade do trabalho no capitalismo leva os professores a enfrentarem problemas humanos em todos os níveis (econômico, político, social, cultural, educacional, saúde, emocional, espiritual) devido às exigências sociais, que se transformam em políticas educacionais públicas para atender aos interesses do capital, preocupando-se com a formação para o trabalho, sem oferecer fundamentos e legitimidade para a valorização humana dos professores na sociedade. Nesse sentido, Mancebo destaca que:

[...] ao lado da possibilidade de os docentes organizarem autonomamente suas práticas e definirem os meios para a consecução de seus objetivos, assiste-se também à imposição, dentro das escolas, de um processo gerencial de trabalho que tem levado progressivamente à perda de autonomia, à desqualificação e à perda do controle do processo quanto do produto do trabalho. (MANCEBO, 2008, p. 8).

Na afirmação de Mancebo, o trabalho docente realizado nas escolas tem resultado num processo contínuo de estranhamento e alienação dos professores. Um processo que pode ser chamado de minimização da autonomia do professor face ao seu trabalho deixando de se autorrealizar no que faz. Um processo de minimização da potencialidade do trabalho, fortalecido pela prática da polivalência na intensificação laboral e no acúmulo de atividades realizadas de forma concomitante. O trabalho que deveria ser humanizado, transforma-se em sinônimo de estresse, sofrimento e frustração. O que deveria ser uma atividade fundamental à humanização do professor passa a ser realizada apenas com a finalidade de mostrar resultados, produtividade e funcionalidade para atender às exigências e aos interesses do capital. O trabalho docente como categoria fundante do ser humano deixa de ser considerado e, igualmente, o próprio professor como ser genérico produtor do trabalho educativo nas escolas.

A desumanização dos professores e do trabalho que realizam nas escolas é um tema que tem sido abordado em diversos estudos, dentre eles, as pesquisas de Ribeiro (2010), Abdalla (2010), Heloaini, (2010) e Landini (2008). Os estudos de Landini apontam para o 
problema de que a saúde dos professores brasileiros encontra-se em risco permanente e que muitos são os fatores que contribuem para o agravamento desse quadro: tipo de atividade exercida, precarização, intensificação desse trabalho, sobrecarga de burocracia e, o principal, a minimização de autonomia. Vários são os tipos de indicadores que evidenciam problemas de saúde desenvolvidos pelos professores pelo excesso de trabalho - psicossomáticos e defensivos - que desencadeiam o absenteísmo, estresse e evasão da docência. Todos esses prejuízos causados diretamente ao professor, afetam também os alunos e a escola em sua totalidade.

Nesse cenário de sofrimento do professor no trabalho, nas últimas décadas, intensificou-se a desumanização no trabalho, impulsionada pelas reformas e políticas educacionais orientadas pela lógica neoliberal. Tornou-se mais evidente os efeitos e as implicações dessa lógicsa no cotidiano docente e escolar. São exemplos que se evidenciam: minimização da autonomia, rotinização das atividades pelo excesso de burocratização, controle externo dos resultados da escola mediante testes padronizados, ampliação da jornada de trabalho do professor, desenvolvimento de patologias, síndrome da desistência, dentre outros. Isso mostra que apenas a valorização salarial dos professores, meio do pagamento do PSPN, torna-se apenas um mecanismo para atender suas necessidades fisiológicas, ocultando a necesidade de valorização do trabalho dos professores e de suas vidas como seres humanos. Por isso, pode-se dizer que os professores são seres humanos alienados pela ação do Estado, que visa atender às exigências e aos interesses do capital, que se reinventam continuamente.

Essa situação de desumanização dos professores mostra como, no capitalismo, a realização do trabalho é desrealização do trabalhador, a efetivação de um produto é sua desefetivação, sua perda, sua servidão em relação ao objeto. O trabalhador empobrece e adoece quanto mais riqueza produz. No caso particular dos professores, quanto mais mais a sociedade demanda o trabalho docente, mais meios são instituídos para sua desvalorização. $\mathrm{O}$ trabalho, portanto, a essência do ser humano, no capitalismo é a atividade alienadora do trabalhador-professor, que acaba se tornando parte do sistema de propriedade privada. $\mathrm{Na}$ perspectiva marxista, isto se chama trabalho alienado, sob o véu da ideologia da classe dominante no país, legitimada pelo Estado.

O trabalho docente, embora diferenciado das demais atividades laborais, na sociedade capitalista, configura-se como trabalho alienado, pois nele encontra-se contido a desumanização dos professores ao perderem a características de seres livres e autoconscientes, de agentes ativos face ao mundo humanamente criado, tornando-se 
fragilizados para tomar as rédeas de suas próprias vidas e ações. É possível identificar pelo menos três movimentos desumanizantes no trabalho docente.

O primeiro movimento dá-se na relação do professor com o produto do seu trabalho, isto é, como um objeto estranho, que o domina. Nesse tipo de relação com o mundo sensorial, os objetos produzidos lhes são estranhos e hostís. O segundo ocorre na relação do trablho com o ato de produção, isto é, do professor com sua própria atividade, enquanto algo estranho e não pertencente a ele mesmo. Nesse caso, é uma atividade que envolve sofrimento em função da posição de passividade do indivíduo professor, da sua impotência diante de um processo voltado contra si.

O terceiro movimento ocorre de forma mais complexa e consiste na transformação do seu modo de vida como espécie humana em um meio de subsistência individual. Nesse caso, a atividade vital humana aparece como simples meio para sua satisfação da necessidade de manter a existência física do professor. Embora, na condição de ser autoconsciente, o professor devesse tomar as rédeas da sua vida, o que ocorre é a transformação de toda a atividade vital em um meio para busca da sobrevivência. A própria vida genérica ativa se torna apenas um meio e não o fim de toda a sua atividade humana. Marx afirma que

o que é verdadeiro quanto à relação do homem com o seu trabalho, também o é quanto à sua relação com outros homens. Assim, cada indivíduo é alienado por outros e todos são igualmente alienados da vida humana, uma vez que cada um encara o semelhante conforme os padrões e relações em que se encontra como trabalhador. (MARX, 2008, p. 35).

Na perspectiva de superação do trabalho alienado no sistema capitalista, Marx aborda a valorização real do trabalho humano e da emancipação humana do trabalhador. Para ele o trabalho humano tem um caráter profundamente positivo, pois, por meio dele o ser humano age sobre a natureza produzindo sua existência e a condição de ser genérico. O trabalho é, assim, a categoria fundante do ser humano. Marx e Engels asseveram que é por meio dessa atividade teleológica que determina as diferenças entre os homens e os animais:

[...] distinguir os homens pela consciência, pela religião, por tudo o que se quiser. Mas eles começam a distinguir-se dos animais assim que começam a produzir os seus meios de vida, passo este que é condicionado pela sua organização física. Ao produzirem os seus meios de vida, os homens produzem indiretamente a sua própria vida material. (MARX e Engels, 1977, p.15).

Para Marx e Engels o trabalho é o que permite ao ser humano construir seu mundo objetivo e a si próprio enquanto indivíduo, buscando a satisfação de suas necessidades. Nesse aspecto, as ações humanas não têm por base uma natureza pronta, imutável, mas se 
referem ao ser humano ativo na construção de si mesmo, da natureza e da História. Ao se apropriar dos objetos em suas relações com o mundo, o ser humano cria, simultaneamente, suas dimensões biológicas, materiais e espirituais, já que os sentidos humanos são vistos como coletivos em sua forma e dependentes do modo como objetiva a natureza. Assim, a esfera natural é apropriada como parte do corpo humano, pois a criação do mundo cultural depende dos meios fornecidos pelo mundo sensorial. Para além da construção de simples meios de sobrevivência, o homem estabelece uma mediação entre si e a natureza, produzindo e reproduzindo sua existência material, vital e espiritual.

O trabalho de construção de um mundo objetivo, fruto da ação humana sobre a natureza, relaciona-se com a autorrealização do ser humano, com a sua formação plena. Esse processo não pode, portanto, encontrar seu termo, uma vez que a necessidade é o próprio ser do ser humano no mundo, constitutiva da sua existência. Entretanto, a práxis humana não é totalmente natural, pois, ao nascer, o ser humano encontra um mundo que insuficiente para a satisfação de suas necessidades, de modo que precisa alterá-lo, objetivá-lo e mediá-lo incessantemente.

Por isso, mediante a força do capital na ordem capitalista, o que importa, no fim das contas, é a libertação do homem de um gênero de trabalho destrutivo em relação à sua individualidade e que o torna escravo de coisas criadas por ele mesmo. Trata-se do retorno à atividade não alienada e, portanto, livre, que permita florescer numa sociedade em que a emancipação plena do ser humano seja o objetivo e não a comercialização de mercadorias. Isso demonstra que o objetivo de Marx não é meramente apontar o rumo da prosperidade econômica do trabalhador, para que venha a possuir o mesmo que o capitalista, mas envolve uma visão ontológica alicerçada na ideia de emancipação do ser humano.

O conceito filosófico de trabalho formulado por Marx (2008) abarca ontologicamente toda a existência do homem. Não se trata de uma atividade determinada, como no sentido econômico, mas a práxis fundamental e específica da espécie humana, na qual há uma união essencial entre ser humano e objetividade. Marx (2008) entende que o caráter de uma espécie qualquer reside no tipo de atividade vital que ela exerce, de forma que o traço distintivo da humanidade seria o fato de o ser humano fazer de sua atividade vital um projeto de sua vontade e de sua consciência. Dessa forma, enquanto o animal é idêntico à sua atividade vital e sua produção não vai além do que necessita imediatamente para si e para sua prole. O ser humano, por meio do trabalho, procede à construção prática de um mundo objetivo, por meio da transformação da natureza inorgânica. Isso é para Marx (2008) a afirmação do ser humano enquanto ser genérico e consciente. 
A argumentação marxiana sobre o sentido do trabalho humano coloca os professores da educação básica num nível de igualdade ontológica aos demais trabalhadores. Por isso eles necessitam ser também emancipados tal como seus pares. Mas, mediante à essa visão de trabalho, pode-se questionar a intenção do Estado ao instituir o PSPN em favor da valorização dos professores, visando, essencialmente, o aumento salarial, para ocultar alienação dos professores como seres humanos e do trabalho educativo que realizam.

$\mathrm{Na}$ perspectiva marxiana, a superação de algo dotado do poder de mistificar a realidade, pelo uso do sublime e do virtuoso, somente pode ocorrer por meio do conhecimento científico, ou do saber real, único elemento capaz de desmarcarar a ideologia burguesa, recolocando de volta o mundo de cabeça para cima, de acordo com o seu sentido real, mostrando a realidade tal como ele o é, destruída dos véus da ideologia. Esse saber real constitui um conjunto de verdades capaz de desmarcarar a falsa consciência, funcionando como ponta-de-lança na luta dos trabalhadores contra o poder hegemônico. Essa concepção de conhecimento é instrumental, à medida que o conhecimento deve ser colocado a serviço das maiorias e da emancipação dos trabalhadores como seres humanos por meio da revolução socialista. Para Marx e Engels,

[...] a existência de ideias revolucionárias, em determinada época, pressupõe já a existência de uma classe revolucionária. Com efeito, cada nova classe que passa a ocupar o posto da que dominou antes dela vê-se obrigada, para poder levar adiante os fins que persegue, a apresentar o seu próprio interesse como interesse comum de todos os membros da sociedade, isto é, expressando isso em termos de ideias, a imprimir em suas ideias a forma do geral, a apresentar essas ideias como as únicas racionais e dotadas de vigência absoluta. (MARX e Engels, 1977, p. 50).

Na perspectiva de Marx e Engels (1958), o conhecimento científico é considerado como uma ação humana sublime, individual e coletiva, uma ferramenta revolucionária na luta dos trabalhadores para superação da alienação e da ideologia impostas pela classe dominante sobre a sociedade, na perspectiva da emancipação humana por meio da recuperação do sentido coletivo do trabalho social.

Com base na aproximação com as categorias de ideologia e alienação em Marx e Engels, analisa-se a visão dos gestores e dirigentes sobre a implantação da Lei $11.738 / 2008$. 


\subsection{Visão dos gestores educacionais federais e municipais, e de dirigentes de entidade nacional e sindicais municipais de professores sobre a implementação da Lei 11.738/2008}

Nesta terceira parte faz-se uma análise das visões dos gestores federais e municipais e dirigentes de entidade nacional e sindicais municipais sobre a instituição do PSPN, à luz das categorias marxianas de ideologia e alienação, em três blocos: Bloco A - gestores educacionais federais; Bloco B - gestores educacionais municipais; Bloco C - dirigentes de entidade nacional e sindicais municipais de professores.

Foram realizadas nove entrevistas semiestruturadas no período de 21.11.2012 a 19.02.2013, mediante agendamento individual e roteiro, conforme Anexo 02, e assinatura de termo de consentimento livre e esclarecido, conforme Anexo 03. Em seguida, as informações foram degravadas, sistematizadas e transformadas em excertos para subsidiar o estudo.

De início, apresenta-se o perfil dos gestores e dirigentes, focando-se três aspectos: formação acadêmica, experiências profissionais e em movimentos sindicais.

Quadro 02 - Perfil dos gestores educacionais federais e municipais e de dirigentes de entidade nacional e sindicais municipais de professores.

\begin{tabular}{|c|c|c|}
\hline Blocos & $\begin{array}{l}\text { Código do } \\
\text { anonimato }\end{array}$ & Perfil \\
\hline \multirow{3}{*}{$\begin{array}{l}\text { A } \\
\text { Gestores } \\
\text { Educacionais } \\
\text { Federais }\end{array}$} & $\begin{array}{l}\text { Gestor } \\
\text { Federal } 1\end{array}$ & $\begin{array}{l}\text { Professor de História da Educação; mestrado em planejamento da } \\
\text { educação; ex-secretário municipal e estadual de educação; ex- } \\
\text { governador. }\end{array}$ \\
\hline & $\begin{array}{l}\text { Gestor } \\
\text { Federal } 2\end{array}$ & $\begin{array}{l}\text { Profesora formada em pedagogia; mestrado e doutorado em educação; } \\
\text { ex-dirigente sindical. }\end{array}$ \\
\hline & $\begin{array}{l}\text { Gestor } \\
\text { Federal } 3\end{array}$ & $\begin{array}{l}\text { Professor de História; graduado em Filosofia e pós-graduado em } \\
\text { História; ex-dirigente sindical. }\end{array}$ \\
\hline \multirow{3}{*}{$\begin{array}{l}\text { B } \\
\text { Gestores } \\
\text { municipais }\end{array}$} & $\begin{array}{l}\text { Gestor } \\
\text { Muncipal } 1\end{array}$ & Professora de ensino superior; ex-secretária de educação \\
\hline & $\begin{array}{l}\text { Gestor } \\
\text { Municipal } 2\end{array}$ & Professor da rede municipal de ensino; ex-dirigente sindical \\
\hline & $\begin{array}{l}\text { Gestor } \\
\text { municipal } 3\end{array}$ & $\begin{array}{l}\text { Professor da rede municipal; diretor escolar; secretário municipal de } \\
\text { educação }\end{array}$ \\
\hline \multirow{3}{*}{$\begin{array}{l}\text { C } \\
\text { Dirigentes de } \\
\text { entidade nacional } \\
\text { e sindicais } \\
\text { municipais }\end{array}$} & $\begin{array}{l}\text { Dirigente } \\
\text { Nacional } 1\end{array}$ & Professor da rede estadual de ensino; ex-dirigente sindical. \\
\hline & $\begin{array}{l}\text { Dirigente } \\
\text { Municipal } 1\end{array}$ & Professor da rede municipal de ensino; ex-diretor escolar \\
\hline & $\begin{array}{l}\text { Dirigente } \\
\text { Municipal } 2\end{array}$ & $\begin{array}{l}\text { Professora da rede municipal de ensino; agente de saúde; secretária geral } \\
\text { do sindicato. }\end{array}$ \\
\hline
\end{tabular}

Fonte: elaborado pelo autor a partir das entrevistas semiestruturadas.

O quadro 02 mostra que os gestores e dirigentes têm formação de nível superior graduação e pós-graduação no campo da educação e/ou em áreas similares; são professores 
efetivos da educação básica; foram ou ainda são dirigentes de entidades nacional e sindicais municipais, que lutam em favor educação pública e, particularmente, pela valorização dos profissionais da educação básica.

Um dado que deve ser considerado é o fato de que os gestores educacionais federais e municipais, em suas trajetórias passadas, já exerceram funções de dirigentes de entidades sindicais de professores, situações estas que os levou a se envolver mais diretamente na luta pela instituição do PSPN, pela implantação dos planos de carreira e outras bandeiras da categoria de professores da educação pública. Sobre essas experiências anteriores, um dos gestores federais assim se manifesta, sintetizando o pensamento dos demais:

[...] porque eu vivi o outro lado. Saí do sindicato e fui para o lado do diferentes sobre o mesmo tema, embora muitas vezes mantém-se o mesmo propósito, a mesma ideologia, o mesmo projeto, mas descobre também coisas novas. Muda-se o ângulo de visão sobre o mesmo assunto (Gestor Federal 1)

Deste modo, as experiências anteriores como dirigentes sindicais poderiam facilitar as suas relações e negociações políticas e técnicas com os dirigentes e gestores dos entes federados e de outros segmentos envolvidos com a questão da valorização dos profissionais da educação básica. Atualmente (2015) exercem funções de gestores governamentais, mas já viveram experiência do lado das reivindicações dos profissionais da educação. Portanto, espera-se que conheçam bem os problemas reivindicados pelos profissionais da educação básica e assim possam agir nas articulações e negociações políticas e técnicas que realizam com outros gestores federais e com demais dos entes federados.

Entretanto, mesmo contando com essas experiências de gestão nas articulações com os entes federados, existem fatores de ordem econômica, política e institucional que dificultam o avanço nas negociações com os entes federados. Como exemplo, a situação conflitante presente no chamado pacto federativo disposto na CF de 1988: ao mesmo tempo que serve de parâmetro para as negociações com os entes federados, também preserva um tipo de autonomia que dificulta e fragiliza a construção dos pactos necessários no campo da educação pública.

Outro dado refere-se ao fato de que todos os gestores e dirigentes são professores efetivos em suas respectivas redes de ensino estaduais e municipais. Isso significa que existe interesse particular e um denominador comum entre eles, que é a luta pela valorização da categoria de professores, tendo a instituição do Piso Salarial Profissional Nacional como elemento principal, em seus atos e ações em diferentes espaços de gestão. 


\subsubsection{Bloco A: Gestores educacionais federais}

Este primeiro bloco estrutura-se em três eixos. No primeiro analisa-se o envolvimento, as experiências e ações dos gestores educacionais federais em favor da instituição do PSPN; no segundo faz-se uma análise da visão dos gestores educacionais federais sobre como vem sendo negociada a instituição do PSPN após a sanção da Lei 11.738/2008; como se configuram as principais dificuldades que obstaculizam o processo de instituição do Piso Salarial Profissional Nacional; e como a instituição do Piso Salarial Profissional Nacional valoriza os professores nos entes federados. No terceiro eixo analisa-se a visão dos gestores educacionais federais acerca de como vem sendo negociada a implantação dos planos de carreira dos professores pelo governo com os entes federados; como devem ser estruturados (elementos básicos) os planos de carreira; e como as ações dentro dos planos de carreira valorizam os professores. Cada eixo é analisado à luz das categorias marxianas de ideologia e alienação, com vistas a desvelar o que pode haver de ideologia e alienação nos discursos e práticas dos gestores educacionais federais.

\section{$1^{\circ}$ Eixo: Envolvimento, experiências e ações em favor da instituição do Piso Salarial Profissional Nacional}

Neste primeiro eixo, o objeto analisado são os comentários dos gestores educacionais federais a respeito do envolvimento, experiência e ações que realizaram até hoje no processo de instituição do PSPN. Foi solicitado que comentassem como se envolveram no processo de instituição do PSPN. Em resposta, assim se manifestaram:

Fui professor da educação básica, militei no Sindicato dos Professores no Acre, fiz greve, negociei com governadores, participei de congressos nacionais da categoria. Então eu vivo ao zimboléu com esse tema por muito tempo e sou muito otimista com relação às possibilidades desse assunto (Gestor Federal 1)

Tive parte efetiva na construção do Piso Salarial Profissional Nacional ao longo de toda minha trajetória profissional e, particularmente, como militante do Sindicato dos Professores Públicos do Estado do Rio Grande do Sul (Gestor Federal 2).

Minhas experiências com a instituição do Piso Salarial Profissional Nacional são antigas. Fui fundador do Sindicato dos Trabalhadores da Educação de Minas Gerais e dirigente (presidente) por diversos mandatos. Participei também do Conselho da CNTE, que antes era a CPB (Gestor Federal 3).

Percebe-se que nessas expressões há uma intenção, um objetivo, uma meta, um sonho, um desejo dos gestores educacionais federais de lutar pela instituição do PSPN. Essa 
motivação presente nos comentários dos gestores federais vem em direção ao que se argumenta constantemente em favor da valorização do magistério. Essa expressão circula largamente nos discursos das escolas, dos sindicatos, dos governos, da imprensa, dos partidos políticos e dos professores. Segundo um dos entrevistados (Gestor educacional federal 1), essa expressão abrange duas dimensões: objetiva - regime de trabalho, piso salarial profissional, carreira docente com possibilidade de progressão funcional, concurso público de provas e títulos, formação e qualificação profissional, tempo remunerado para estudos, planejamento e valorização, assegurado no contrato de trabalho, e condições de trabalho; e subjetiva - reconhecimento social, autorrealização e dignidade profissional. Percebe-se também que essa motivação dos gestores federais em prol das duas dimensões da valorização do magistério, foi criada em função de um determinado modelo de sociedade historicamente situada. Assim, percebe-se que o envolvimento, as experiências e ações dos gestores federais em favor da instituição do PSPN contribuem para a manutenção desse modelo de sociedade, que acreditam ser benéfico à política de valorização do trabalho docente.

Desse modo, pode-se dizer que por trás do envolvimento, das experiências e ações dos gestores federais em favor da instituição do PSPN existem contradições que precisam ser desveladas.

A primeira consiste no descolamento do contexto histórico no qual sonham e trabalham em favor da valorização dos profissionais da educação básica. Em seus comentários não se percebe alguma conexão com a realidade concreta, histórica, ou seja, não situam seus sonhos, desejos, motivações e práticas no contexto da sociedade brasileira, estruturada fundamentalmente no conflito entre os grupos dos capitalistas e a classe dos trabalhadores assalariados, da qual faz parte a categoria de professores da educação básica, cuja valorização salarial é realizada pelo governos federal, estaduais e municipais.

O descolamento do contexto histórico caracteriza-se como alienação dos gestores federais e do trabalho que vêm realizando em favor da instituição do PSPN. Sem situarem a instituição do PSPN no contexto histórico, os gestores federais se perdem enquanto sujeitos participantes na transformação da relação de dominação e exploração na sociedade brasileira e se transformam em sujeitos legitimadores da engrenagem de funcionamento do Estado que, na sociedade de classes, tem como função proteger e legitimar a ordem capitalista vigente no país, embora proclame que sua função seja a de promover interesses gerais.

Outra contradição nos comentários dos gestores federais diz respeito à positividade que envolve a expressão "valorização dos profissionais da educação básica”, por meio da instituição PSPN. Tal expressão, da forma como é utilizada pelos gestores federais, contribui para ocultar a 
minimização da potencialidade ontológica do trabalho docente. No entendimento de Mattos (2009), a expressão é utilizada para esconder a indissociável conexão entre a valorização dimensão ontológica do ser social dos docentes com o sentido do trabalho que realizam nas escolas.

Pontua-se que a positividade que envolve a expressão "valorização dos professores da educação básica”, na visão dos gestores federais, padece de superficialidade porque não leva em conta fundamentos filosófico-antropológicos da relação trabalho-educação. Tal expressão não considera a ideia de que é característica própria do ser humano realizar ações específicas de trabalhar e educar. Somente o ser humano trabalha e educa, pois a essência do ser humano não lhe é dada em forma de dádiva divina ou natural ou algo que precede sua existência, mas, ao contrário, é produzida pelo ser humano no trabalho. Assim, pode-se dizer que a expressão em favor da valorização dos professores da educação básica, utilizada pelos gestores federais, contibui para ocultar o real sentido do trabalho docente e da existência dos professores enquanto seres humanos, que é o trabalho docente nas escolas e noutros ambientes educacionais.

Enfim, ao ocultarem o contexto histórico no qual trabalham em favor da valorização dos profissionais da educação básica, os gestores federais dissimulam a dimensão essencialmente política do trabalho que realizam ao longo de muitos anos, pois "numa sociedade em conflito toda ação no campo da educação é política e consiste em assumir uma postura a favor ou contra os interesses das classes dominantes ou dos grupos dominados.” (GADOTTI, 1985, p.75),

Assim, pode-se dizer que os trabalhos, experiências e ações que os gestores federais vêm desenvolvendo em favor da valorização dos professores da educação básica escondem, embora contribuam para legitimar a função do Estado de proteger o sistema do capital no país, ao mesmo tempo, buscam fortalecer as o movimento contrário às desigualdades de classe no campo da educação básica.

No $2^{\text {o }}$ eixo, aborda-se a visão dos gestores educacionais federais sobre a valorização dos professores da educação básica por meio da instituição do PSPN.

\section{$2^{\circ}$ Eixo: Valorização por meio da instituição do Piso Salarial Profissional Nacional}

Neste segundo eixo, faz-se uma análise da visão dos gestores educacionais federais sobre a valorização dos professores da educação básica, por meio da instituição do PSPN. Analisa-se o que dizem sobre como vem sendo negociada a instituição do piso salarial após a sanção da Lei 11.738/2008; como se configuram as principais dificuldades que obstaculizam o processo de instituição do PSPN; e acerca de como a instituição do PSPN valoriza os 
professores nos entes federados. Foi perguntado aos gestores: como vem sendo negociada a instituição do PSPN? Em resposta, assim se expressaram:

\begin{abstract}
A instituição do piso salarial hoje é de difícil negociação e o MEC tem ajudado, discutindo e fazendo a mediação. O MEC tem incentivado no sentido de que proponham alternativas e algumas estão surgindo. A Undime, a Cnte construiram uma proposta que está mais próximo da realidade, propondo a desvinculação o VAA do valor total de recursos do Fundeb, que é a soma de todos os fundos (Gestor Federal 1).
\end{abstract}

Tem gestores que organizaram os planos de carreira para integralizar o pagamento do piso salarial no período de transição previsto em lei. Outros simplesmente ignoraram a necessidade de avaliar o plano de carreira que existia no município e no Estado e da sua reformulação para adequação à Lei do Piso, sem fazer a integralização necessária dentro do tempo previsto. O MEC tem procurado negociar com os entes federados o cumprimento da Lei do Piso (Gestor Federal 2).

O MEC tem incentivado os governos estaduais e municipais a cumprirem a Lei do Piso. Além disso, conforme previsto em lei, o MEC deve utilizar parte do Fundeb (10\%) para complementação do piso nos entes federativos que comprovarem incapacidade financeira para pagar o piso salarial. Então, MEC tem essa obrigação legal. Enfim, temos acompanhado toda a discussão no Congresso Nacional sobre o PL que modifica (Gestor Federal 3).

$\mathrm{Na}$ visão dos gestores federais, a negociação para instituição do PSPN nos entes federados vem sendo coordenada pelo MEC. Apontam o MEC como o principal articulador e negociador dessa ação do Estado em favor da valorização dos profissionais da educação básica. Isso implica num diálogo contínuo do Estado, por meio do MEC, com os sujeitos envolvidos no processo de implementação da Lei do Piso, dentro do pacto federativo disposto na CF de 1988 que, por um lado, propicía condições para as negociações entre as três instâncias da Federação, mas, ao mesmo tempo, dificulta o encaminhamento das negociações, em razão da proclamada autonomia dos entes federados. Assim, as negociações em favor da instituição do PSPN e de outros temas que envolvem a educação pública caminham paulatinamente, quando já deveriam ter evoluído muito mais.

A visão dos gestores federais aponta o MEC como o principal articulador e negociador da ação do Estado em favor da valorização dos profissionais da educação básica, por meio da instituição do PSPN, sem levar em conta o contexto histórico no qual o Ministério operacionaliza tal ação. Falam das negociações como se fossem ações governamentais realizadas fora da realidade histórica e social, como se fossem simples abstrações. Desse modo, desconectam a ação concreta do Estado do contexto social, político e econômico da sociedade brasileira em conflito. 
Nesse modo de ver as negociações coordenadas pelo MEC, os gestores federais ocultam o papel eminentemente político da ação do Estado que, em nome dos interesses gerais, garante os privilégios e interesses das classes dominantes na sociedade brasileira, embora isto não apareça de imediato ao afirmarem que "[...] o MEC tem incentivado os governos estaduais e municipais a cumprirem a Lei do Piso e [...] que proponham alternativas para novas negociações e [...] que tem acompanhado toda a discussão no Congresso Nacional sobre o piso salarial" (Gestor educacional federal 1)

Nessa afirmação, a ação do MEC realmente é executada em favor dos interesses dos professores, porém, os gestores federais não se dão conta de que ela ocorre de forma desconectada da realidade, e a realidade é a sociedade brasileira estruturada em classes sociais com interesses opostos. Desconectam o papel do Estado na sociedade capitalista de promover e preservar os privilégios e interesses dos grupos dominantes. Assim, de fato, a visão dos gestores federais acaba contribuindo para camuflar o sentido da negociação coordenada pelo MEC, que consiste em negociar é o mecanismo que o Ministério utiliza no processo de informação e manter o poder político para influenciar o comportamento dos entes federados dentro de um movimento de diálogo e colaboração, fazendo prevalecer os interesses do governo, da União, do Estado.

Ainda neste segundo eixo, foi perguntado aos gestores educacionais federais: como se configuram as principais dificuldades que obstaculizam o processo de instituição do Piso Salarial Profissional Nacional? Em resposta, assim se manifestaram:

Existem problemas graves de caixa, de ajuste de gestão e de carreira que precisam
ser pensados e resolvidos. [...] A dificuldade de pagar o piso é a desvinculação entre
piso e carreira, que está no nascedouro da construção do piso. Há desvinculação
também entre piso e gestão da educação. [...] O problema é que na ausência de um
Sistema Nacional de Educação que inviabiliza a existência de qualquer referência do
que é certo ou errado. Ainda sobre a gestão, há muitos professores fora da escola
(Gestor Federal 1).

As fontes para o financiamento da educação ainda não estão totalmente resolvidas. A criação de um Sistema Nacional de Educação poderia trazer soluções para diversos problemas políticos e de ordem econômico-financeira (Gestor Federal 2).

A forma de reajuste do piso baseada no VAA. [...] O cumprimento do que etermina a lei sobre 1/3 da hora/atividade. [...] A relação número de alunos e professor muito baixa. Mas, a principal dificuldade é a ausência de um Sistema nacional de Educação que possibilite a criação de espaços democráticos propícios às negociações (Gestor Federal 3).

$\mathrm{Na}$ visão dos gestores federais, a maior dificuldade que obstaculiza a instituição do PSPN é a inexistência de um Sistema Nacional de Educação (SNE) que sirva de parâmetro às 
ações implementadas pelo governo, via Divape/Sase/MEC, com os entes federados e outros segmentos envolvidos na política de valorização dos profissionais da educação básica.

Além da inexistência de um SNE, apontam outra dificuldade que consiste no modo de reajustar o piso salarial baseado no Valor Aluno Ano (VAA). Consideram o VAA como problema porque cresce ou diminui sem relação direta com o montante de recursos disponíveis, tornando-se incompatível com a disponibilidade de receita dos cofres dos entes federados. Uma pequena alteração no número de alunos para mais ou para menos, cria um problema sério que pode afetar o planejamento orçamentário e financeiro dos entes federados, obstaculizando a instituição e o pagamento do piso salarial.

Um exemplo dessa dificuldade ocorreu em 2011, quando o índice de reajuste do piso salarial foi de $22,22 \%$, sem o aumento da receita. Houve uma queda no número de alunos por vários motivos, dentre eles, a redução da repetência, melhorando o fluxo e retendo menos alunos na educação básica; e o maior equilíbrio da natalidade, diminuindo o crescimento demográfico em alguns lugares. Mas o custo das redes de ensino não diminuiu porque o número de professores continuou o mesmo e as despesas com manutenção das escolas continuam as mesmas. Então, aparentemente aumentaram os recursos porque aumentou o valor por aluno, mas o valor por aluno não aumentou o valor total de recursos e a folha de pagamento não parou de crescer. A folha de pagamento tem um crescimento vegetativo e como existe um déficit grande no ensino médio e na educação infantil, também há necessidade de se contratar mais professores, construir mais escolas e a ampliar a oferta nessas áreas, quando a receita para pagamento do piso salarial consiste no volume de recursos do Fundeb dividido pelo número de alunos.

Ao apontarem a inexistência de um SNE e o modo de rejustar o PSPN baseado no VAA como as principais dificuldades na instituição do PSPN, de fato, os gestores educacionais federais assumem uma postura política que poderia ser chamada de funcionalista, por entenderem que a criação de um SNE e a substituição do VAA por outros tipos de reajustes do piso salarial é suficiente para solucionar esses problemas e outros que envolvem a política de valorização dos profissionais da educação básica. Entretanto, apenas aperfeiçoar os processos, os mecanismos e as ferramerntas do sistema educacional nacional, pode significar apenas melhorar o atendimento às demandas do Estado de maneira eficaz $\mathrm{e}$ eficiente, em razão das exigências impostas pelo sistema capitalista vigente no país, dentro da onda onda neoliberal iniciada entre na década de 1990 no governo do então Presidente Fernado Henrique Cardoso. 
Ainda neste segundo eixo, foi perguntado aos gestores educacionais federais: como a instituição do Piso Salarial Profissional Nacional valoriza os professores nos entes federados? Em resposta, assim se manifestaram:

\begin{abstract}
O conceito de piso salarial não é apenas o resultado de uma luta corporativa, mas uma necessidade da nação. [...] é claro que a gente tem que se preocupar com a valorização dos professores. [...] mas a finalidade da educação é garantir um ensino de qualidade para o povo brasileiro. Um bom salário no começo. $\mathrm{O}$ piso tem que ser de grande atratividade porque quando o professor faz concurso não olha o salário do final, mas do início da carreira, pois, assim, ele vai ficar muito tempo até o final da carreira. Daí a importância da instituição do Piso Salarial Profissional Nacional para a implementação de um Sistema Nacional de Educação (Gestor federal 1).
\end{abstract}

A instituição do piso pelo menos criou uma centralidade e motivou uma preocupação para os gestores. Foi um grande ganho do magistério porque antes era apenas uma coisa a ser vista, ou seja, sempre marcavam para começar a pensar a questão depois das eleições. A instituição do piso salarial pode ser agilizada mais ainda com a criação de um Sistema Nacional de Educação (Gestor Federal 2).

É importante que tenha uma coerência no conceito de piso e carreira. A educação precisa ser um espaço que seja atraente, especialmente do ponto de vista salarial. A relação entre vencimento inicial e o final da carreira não pode haver uma dispersão tão longa como ocorre hoje em muitos lugares. O piso salarial, obviamente, não é o elemento único de valorização, mas é essencial. Sem ele torna-se impossível falar em valorização dos profissionais de educação. Enfim, o objetivo do piso salarial não é apenas responder à uma necessidade reivindicatória do sindicato [...] é uma necessidade do sindicato, dos gestores, do povo brasileiro, enfim, de todos. Todos nós precisamos lutar por isso, pois a luta pelo piso salarial é para fazer com que todos os professores tenham a valorização que merecem. E mais, o piso salarial é um elemento fundamental para o funcionamento de um Sistema Nacional de Educação e vice-versa (Gestor Federal 3).

Na visão dos gestores federais, a instituição do PSPN é a principal ação do Estado nos últimos tempos visando a valorização dos professores da educação básica, em que pese as dificuldades políticas, econômicas e institucionais que se impõem, ressaltam que o PSPN não pode ser irrisório, mas muito valorizado e atraente. $\mathrm{O}$ candidato que vier a fazer concurso para exercer a profissão de professor deve estar estimulado ao exercício do magistério desde sua entrada na carreira, pois a maior motivação, um bom salário desde o ínicio e ao longo de toda a carreira profissional. Por isso o sinônimo de valorização dos professores deve ser salário potente, pois, desse modo, os interessados passam a disputar no mercado de trabalho e pode optar em ser professor ou assumir outra profissão. Enfim, ressaltam que as condições materiais e políticas necessárias para que isso aconteça estão sendo recriadas pelo Estado pelos exercícios do modo de reprodução e acumulação capitalista.

Outra questão apontada pelos gestores federais é a relação entre a instituição do PSPN para implantação de um SNE. Significa não uma mera formalidade legal, mas uma ferramenta 
para processar as negociações em torno da política de valorização dos profissionais da educação básica, tendo em vista o avanço da educação brasileira com qualidade. O SNE é entendido como a ferramenta necessária para possibilitar e assegurar a oferta de uma educação pública com qualidade, equidade, gratuita para todos os brasileiros, propiciando a superação das situações díspares entre os entes federados.

$\mathrm{Na}$ visão dos gestores federais, o SNE é o caminho para superar as disparidades econômico-financeiras dos entes federados e chegar à eqüidade na distribuição dos recursos pertinentes ao financiamento da educação básica. Há uma disparidade econômico-financeira muito grande entre os entes federados, resultante da arrecadação diferenciada de impostos, refletindo diretamente na qualificação e valorização dos professores. Consequentemente, não há equidade e distintos critérios de medir a qualidade da educação no país. Por isso, pontuam que o sonho de um SNE é o de que todo cidadão brasileiro tenha acesso à educação com a mesma qualidade. Qual qualidade? Parece ser aquela aferida nos índices, ou seja, a educação ofertada em todos os espaços educacionais no país, pobres ou ricos, abstraindo as desigualdades existentes ao elegerem um padrão de qualidade. Daí a associação do PSPN com o SNE na visão dos gestores federais.

A visão dos gestores federais reflete os discursos e ações governamentais, que proclamam a positividade da instituição do PSPN, considerado o mecanismo principal de valorização dos professores da educação básica. Desse modo, maximizam a importância da instituição do PSPN para a valorização dos docentes, visando, essencialmente, o seu empoderamento econômico e financeiro, para que possam comprar mercadorias necessárias à sua sobrevivência física - mesmo assim o valor pago pelo trabalho docente tem sido abaixo do valor pago a outros profissionais -, mas, ao mesmo tempo, contribui para esconder a despotencialização do trabalho docente nas escolas.

Os gestores educacionais federais sentem-se confortados dentro do sistema de alienação e não atentam para o fato de que a instituição do PSPN, sendo uma ação política do Estado no âmbito da ordem capitalista vigente no país, contribui para manter esse sistema de ocultação da realidade concreta. Neste contexto, Marx afirma:

o aumento de salário não passa de uma remuneração melhor de escravos, pois não representa a restauração do significado e valor humanos do trabalho e do trabalhador. O sistema de salários, na medida em que remunera o trabalhador, é uma consequência necessária da alienação do trabalho. Do mesmo modo, a igualdade de renda não modifica a relação do trabalhador com o seu trabalho, somente torna a sociedade uma espécie de capitalista abstrato. (MARX, 1996, p. 70). 
Nesse sentido, a visão dos gestores educacionais federais não é neutra e sim de acomodação, pois reflete a postura e o compromisso do Estado em favor de um determinado projeto educacional, dentro de um modelo de Estado e de uma sociedade de classes com interesses opostos, historicamente situada. Por isso faz sentido a vinculação entre PSPN e SNE na visão do Estado, que é a de agilizar o processo de funcionamento da educação em sintonia com a ordem capitalista vigente no país.

Pode-se dizer, ainda, que a visão dos gestores federais se insere no movimento de reformas neoliberais das políticas educacionais brasileiras desde a década de 1990, nos dois mandatos do Presidente Fernado Henrique Cardoso, e ajustadas nos governos do Presidente Luiz Inácio Lula da Silva, de 2002 a 2010, e da Presidente Dilma Rousseff, de 2010 até o presente (2015), incorporando as orientações políticas das agências multilaterais de financiamento para a construção de consensos em torno da necessidade de reformas educativas, para atender às novas exigências postuladas pelo ideário neoliberal.

Nas sociedades neoliberais, o Estado cumpre papel precípuo na preservação da ordem burguesa e reorganiza suas funções políticas, econômicas e ideológicas conforme as configurações conjunturais processadas a cada estágio de desenvolvimento do capital. Em seu estágio atual, caracterizado pela máxima do capital financeiro, as reformas do Estado são condicionantes que possibilitam ao capital enfrentar suas crises e se rearticular de forma globalizada.

No Brasil, essas configurações conjunturais são fortemente impostas e conduzidas pelas agências internacionais que definem estratégias de políticas de arranjos e ajustes estruturais, as quais implicam na redução dos investimentos públicos nas politicas sociais e sua consequente subordinação à política econômica. Com o suposto discurso de garantir a competividade dos países em desenvolvimento, amaciando os níveis de pobreza e miséria, as agências internacionais influenciam nas reformas econômicas, sociais, políticas e educacionais desses países, como é o caso do Brasil, ajustando-os às novas exigências da ordem capitalista e promovendo mais ainda o acirramento da dependência financeira em relação aos países centrais controladores da força do capital.

Nesse contexto, Silva (2003), analisa as relações estabelecidas entre a equipe de diretores, técnicos e conselheiros do Banco Mundial, autores de um projeto para a educação pública que conta com a conivência da equipe brasileira do Ministério da Educação. Nas palavras da autora:

O Banco Mundial chega ao interior das escolas públicas por meio de programas, projetos e planos elaborados por seus técnicos e conselheiros e endossados pelo Ministério da Educação, separando o pensar do fazer. A comunidade escolar é 
apenas informada sobre os programas, projetos e planos, recebendo orientações necessárias ao preenchimento de formulários e à prestação de contas. A reflexão sobre o trabalho pedagógico diluiu-se em meio a tanto procedimento burocrático a serem cumpridos. (SILVA, 2003, p. 299).

A afirmação de Silva (2003) expressa a relação de poder entre as equipes do Banco Mundial e Ministério da Educação, afirmando que ocorre uma apropriação das estrururas institucionais educacionais do país por meio do desenvolvimento de projetos, programas e planos que alcançam o coração das escolas públicas, entre eles o projeto politico-pedagógico, que é o documento orientador das práticas educativas na escola.

Nessa linha de raciocínio, as reformas promovidas pelo governo do Presidente Fernado Henrique Cardoso a partir da década de 1990, passando pelos dois mandatos do Presidente Luiz Inácio Lula da Silva, sob as orientações das agências internacionais, especialmente a do BM e da Cepal, novas demandas foram lançadas para a política educacional com o propósito de adequá-la aos interesses econômicos regulados pelo mideário neoliberal. As propostas de uma educação básica de qualidade, como instrumento necessário ao desenvolvimento econômico dos países e como forma de assegurar a equidade, tendem, assim, a se tranformarem em discursos oficiais para estabelecer um consenso geral, bem como na formação de valores e atitudes desejáveis para a manutenção e reprodução da ordem capitalista vigente. Assim, novas relações entre Estado e sociedade são definidas para a conformação social, tendo, na educação, instrumento relevante de legitimação das relações sociais vigentes.

Seguindo essa linha de abordagem, analisa-se no $3^{\circ}$ eixo, a visão dos gestores educacionais federais sobre o processo de implantação dos planos de carreira.

\section{$3^{\circ}$ Eixo: Implantação dos planos de carreira para os professores}

Neste terceiro eixo, faz-se uma análise dos discursos e ações dos gestores educacionais federais a respeito de como vem sendo negociada a implantação dos planos de carreira dos professores pelo o governo com os entes federados; como devem ser estruturados (elementos estruturantes) os planos de carreira; e como as ações dentro dos planos de carreira valorizam os professores.

Perguntou-se aos gestores educacionais federais: como vem sendo negociada a implantação dos planos de carreira dos professores pelo o governo com os entes federados? Em resposta, assim se manifestaram: 
O gestor municipal ou estadual precisa ter consciência de que a carreira é importante para que se obtenha resultados efetivos na melhoria da qualidade da educação. Uma carreira atrativa para os professores. Um bom salário no começo e no final. $\mathrm{O}$ MEC, por intermédio da Sase, tem um papel fundamental nas negociações. E os planos de carreira devem estar alinhados ao Plano Nacional de Educação (Gestor Federal 1).

É preciso que tenha uma boa negociação no processo de instituição dos planos de carreira. Nessa negociação, o trabalho realizado pela Divape/Sase/MEC é muito importante e deve considerar o que dispõe o Plano Nacional de Educação. Nessa negociação deve ser levado em consideração a formação inicial, carga horária compatível, gratificações, tudo que diz respeito às condições de trabalho, licenças necessárias para tratamento sem punição (Gestor federal 2).

É fundamentalmente necessário que haja uma negociação entre os entes federados no processo de elaboração dos planos de carreira. E o MEC vem desenvolvendo um trabalho de articulação importante junto aos entes federados, articulado com o PNE. As negociações devem levar em conta principalmente o vencimento inicial ou piso salarial. O piso salarial tem que estar vinculado à carreira e vice-versa (Gestor federal 3).

$\mathrm{Na}$ visão dos gestores educacionais federais a Divape/Sase é a unidade do MEC reponsável pela implementação de ações direcionada à valorização dos profissionais da educação básica, incluindo as negociações com os entes federados para implementação dos planos de carreira. As ações da Divape/Sase são realizadas em sintonia com a proposta do PNE, especialmente com as metas 17, 18 e 19 da Lei 13.005/2014 e suas respectivas estratégias. Assim, devem ser criadas as condições objetivas para a estruturação e valorização das carreiras do magistério da educação básica dos entes federados.

De fato, conforme relato dos gestores federais, a Divape/Sase, inicialmente, passou a identificar iniciativas pertinentes à valorização dos profissionais de educação nos estados, municípios e Distrito Federal, para estabelecer mecanismos de comunicação e articulações com estes federados e entidades nacional e sindicais de profissionais de educação básica. Por exemplo, a realização de seminários regionais sob a coordenação da Divape/Sase, buscando estreitar as relações institucionais com as secretarias estaduais e municipais de educação,

Com base nesse diagnóstico preliminar, a Divape/Sase elaborou um planejamento estratégico para o período de 2011 a 2014. Em 2012, esse planejamento foi reformulado, em razão do objetivo geral da Sase, que é o de contribuir para a construção de um SNE, dentro do espírito de colaboração e pactuação entre os sistemas de ensino público no país.

Como parte desse planejamento, a Divape/Sase passou a negociar os elementos constitutivos do SNE, no âmbito da Comissão Intergovernamental tripartite, visando à prestação de assistência técnica aos entes federativos para a elaboração ou reelaboração dos planos de carreira dos profissionais da educação; a interação com a Undime, o Consed e a 
CNTE, para a construção de diretrizes e parâmetros de carreira. Muitos entes federados não elaboraram seus planos e outros já elaboraram, mas sem seguir as orientações da Lei 11.738/2008 e das Resoluções 03/2009 e 05/2010 do Conselho Nacional de Educação.

A visão dos gestores federais oculta o contexto histórico no qual são realizadas as negociações da Divape/Sase com os entes federados para implementação dos planos de carreira dos professores. Tratam de questões educacionais desconectadas da realidade social brasileira concreta. Por conseguinte, não atentam para o fato de que as articulações e negociações relizadas pela Divape/Sase/MEC representam acomodações aos interesses do Estado, portanto, embora pareçam ser somente em favor dos interesses dos professores, são realizadas em favor dos interesses dominantes na sociedade. A visão dos gestores federais foge do contexto histórico para manter-se no plano ideológico. Nesse contexto, Saviani assim se expressa: Penso que a tarefa de uma pedagogia inspirada no marxismo implica a apreensão da
concepção de fundo (de ordem ontológica, epistemológica e metodológica) que
caracteriza o materialismo histórico. Imbuído dessa concepção, trata-se de penetrar
no interior do processo peodagógico, reconstruindo suas características objetivas e
formulando as diretrizes pedagógicas que possibilitarão a reorganização do trabalho
edfcativo sob os aspectos das finalidades e objetivos da educação, das instituições
formadoras, dos agentes educativos, dos conteúdos curriculares e dos procedimentos
pedagógico-didáticos que movimentarão um novo éthos educativo voltado à
construção de uma nova sociedade, uma nova cultura, um novo ser humano.
(SAVIANI, 2012, p. 81).

Nessse ponto, Saviani enfatiza que por esse caminho a educação ganha condições de assumir uma perspectiva ontológica, apreendendo o processo de formação humana, como o contínuo movimento de apropriação das objetivações humanas produzidas ao longo da história. Assim, a educação atua no sentido de, a partir das relações alienadas, abolir os entraves que a forma social capitalista vem impondo ao desenvolvimento plenamente livre e universal do ser humano e de sua formação.

Os gestores federais não se dão conta de que a ação do Estado valoriza o salário dos professores, mas despotencializa o trabalho realizado pelos professores no contexto da totalidade da ordem capitalista vigente no país.

Pode-se dizer que a visão dos gestores federais carece de avaliação crítica, deixando de aprofundar questões como estas: quais são os pontos estruturais que dificultam as negociações da Divape/Sase/MEC para a elaboração dos planos de carreira? Que razões explicam as resistências ao processo de elaboração dos planos de carreira? Ao aprofundar essas questões, poderiam ver com clareza a realidade concreta na qual se implantam os planos de carreira dos professores na sociedade brasileira e, desse modo, poderiam ver como a 
proclamada valorização dos professores da educação básica, ao mesmo tempo, minimiza o ser ontológico dos professores e o trabalho que realizam nas escolas públicas.

Ainda neste terceiro eixo, perguntou-se aos gestores educacionais federais como devem ser estruturados (elementos básicos) os planos de carreira? Dentre as respostas obtidas, desta-se esta que, de certo modo, sintetiza as demais:

São vários elementos que devem constituir um plano de carreira, mas, dentre eles, são considerados indispensáveis: vencimento incial ou piso salarial, relação entre formação básica e continuada progressão; formas de promoção profissional com visão de futuro; perspectivas de crescimento não só salarial, mas por merecimento (Gestor federal 3).

$\mathrm{Na}$ visão do gestor federal 3, são diversos elementos que devem constituir um plano de carreira, mas considera a vinculação entre carreira profissional e vencimento inicial ou piso salarial o principal elemento. Isto significa que, se o vencimento inicial na carreira for muito baixo, os jovens com perfis mais adequados para a educação não se sentirão atraídos. E a educação não pode ser um espaço em que vão atuar aqueles profissionais que não conseguiram se colocar em outros espaços profissionais no mercado de trabalho. Ao contrário, a educação precisa ser um espaço atrativo do ponto de vista salarial, para que os jovens que com perfis de educadores sejam atraídos, entrem e permaneçam na carreira exercendo a profissão de professor.

O PSPN sendo o elemento principal na estruturação da carreira, a relação entre vencimento inicial e o final da carreira não pode ter uma dispersão tão longa e muitas gratificações como ocorre hoje em muitos entes federados, impedindo-os de pagar o piso salarial dos professores. Assim, na visão do gestor federal 3, embora o piso seja ainda baixo, tem de ter perspectiva de um crescimento real em médio e longo prazos, para que seja atraente. Desse modo, é possível que diversos elementos sejam inseridos nos planos de carreira, mas o piso salarial é o principal, a base inicial para a valorização dos profssionais a educação. Por isso o plano de carreira, necessariamente, tem que estar vinculado ao piso salarial e vice-versa.

Nesse modo de ver do gestor federal 3, dois pontos merecem atenção. O primeiro refere-se à positividade que é atribuída à implantação dos planos de carreira dos professores da educação básica. Embora considerada como uma ação do Estado, viabilizada por meio das articulações feitas pela Divape/Sase/MEC, tal positividade pode contribuir para esconder uma fantasia, na medida em que consiste num mecanismo de enquadramento dos professores no modelo de organização e preservação do PSPN. Em verdade, por trás da proclamada 
valorização dos professores por meio da implantação dos planos de carreira, minimiza-se o real sentido da valorização dos professores da educação básica, que consiste na emancipação dos professores por meio do trabalho que realizam nas escolas.

O segundo ponto diz respeito à quantidade de elementos que constituem um plano de carreira. São diversos elementos apontados pelo gestor federal 3, que contribuem para ocultar o que deveria ser considerado substancial e mais qualitativo para os professores, ou seja, a valorização do trabalho que realizam e deles como seres humanos. Dentro da lógica de exploração na sociedade brasileira, assim como nas demais sociedades capitalistas, quanto mais aumentar, somar, agregar, ampliar os benefícios em favor dos trabalhadores, consequentemente, mais energias físicas terão para gastar no trabalho, evitando absenteísmo, adoecimentos e outros problemas que, evidentemente, servem para evitar prejuízos econômicos e financeiros ao sistema. No caso dos professores, trata-se de evitar prejuízos aos cofres dos entes federados, portanto, cofres públicos. Por isso, somente inserir grande quantidade de elementos nos planos de carreira implica, de fato, não na valorização concreta dos profissionais da educação básica, mas apenas semeia a ilusão de valorização já que o valor do PSPN continua, até mesmo dentro da ordem capitalista, abaixo do salário de outras profissões.

Enfim, neste terceiro eixo, perguntou-se aos gestores educacionais federais: como as ações dentro dos planos de carreira valorizam os professores? Dentre as respostas obtidas, destaca-se esta que, de certo modo, sintetiza as demais:

Os planos de carreira valorizam os profissionais da educação sobretudo se forem
elaborados com a participação dos professores nas negociaçôes, encampando as suas
necessidades e expectativas. Além do piso salarial, que é a base, outros elementos
de valorização devem ser inseridos nos planos de carreira, como mecanismos claros
de promoção, jornada de trabalho compatível, incentivos para aquisição de recursos
pedagógicos e tenológicos, perspectiva de futuro (Gestor federal 3).

$\mathrm{Na}$ visão do gestor federal 3, cabe aos entes federados compreenderem, reconhecerem e incorporarem as ações que devem constar nos seus planos de carreira em favor da valorização dos professores. Além do PSPN, os elementos que valorizam os professores dentro dos planos de carreira são as condições adequadas de trabalho, os mecanismos claros de promoção, as jornadas de trabalho compatíveis, incentivos para aquisição de recursos pedagógicos e tecnológicos e as perspectivas de futuro. $\mathrm{Na}$ ausência desses elementos, os professores certamente se sentem pouco estimulados para o trabalho nas escolas. Por isso os planos de carreira do magistério podem expressar melhoria dos processos educacionais ao 
contemplarem os elementos psíquicos, culturais, sociais, tendo em vista a um futuro promissor à valorização dos professores.

Esse modo de ver do gestor federal 3, embora não explicitado, considera que o mesmo se alinha ao que se considera como princípios fundamentais para um plano de carreira: o reconhecimento da educação pública e gratuita, de qualidade, como direito de todos e dever do Estado; a gestão democrática, a defesa do financiamento público, que leve em consideração o custo aluno necessário para alcançar a educação de qualidade, garantindo em regime de cooperação entre os entes federados, com responsabilidade supletiva da União. Além destes, o acesso por concurso público de provas e títulos; a remuneração condigna para todos, com vencimentos ou salários iniciais nunca inferiores ao PSPN; o desenvolvimento de ações que visem à equiparação salarial com outras carreiras profissionais de formação semelhante; a progressão salarial na carreira, por incentivos que contemplem titulação, experiência, desempenho, atualização e aperfeiçoamento profissional; a valorização do tempo de serviço prestado pelo servidor ao ente federado; jornada de trabalho preferencialmente em tempo integral de, no máximo, 40 horas semanais; participação na elaboração e no planejamento, execução e avaliação do projeto político-pedagógico da escola e dos sistemas de ensino.

Na visão do gestor federal 3, há uma preocupação com a centralidade do PSPN e a quantidade de elementos considerados complementares de valorização dos professores. Dessa forma, os governos, em nome da valorização dos docentes, por meio dos planos de carreira, contibuem para minimizar a potencialidade do trabalho docente e dos próprios docentes como seres humanos. Percebe-se, assim, que a visão do gestor educacional federal 3 escamotea o trabalho docente que, conforme Saviani,

[...] é o ato de produzir, direta e intencionalmente, em cada indivíduo singular, a humanidade que é produzida histórica e coletiviamente pelo conjunto dos homens. Assim, o objeto da educação diz respeito, de um lado, à identificação dos elementos cultruriais que precisam ser assimilados pelos indivíduos da espécie humana para que eles se tornem humanos e, de outro lado e concomitantemente, à descoberta das formas mais adequadas de atingir esse objetivo. (SAVIANI, 2005, p. 13).

A implantação dos planos de carreira é considerada pelos gestores e dirigentes como avanço na política de valorização dos professores nos sistemas de ensino estaduais e municipais, face às resistências e críticas, mas não levam em conta a potencialidade do trabalho humano realizado pelos professores. 


\subsubsection{Bloco B: Gestores educacionais municipais}

Este segundo bloco estrutura-se em três eixos. No primeiro, analisa-se o envolvimento, experiências e ações dos gestores educacionais municipais em favor da valorização dos professores da educação básica, por meio da instituição do PSPN; no segundo, analisa-se a visão dos gestores educacionais municipais sobre como vem sendo negociada a instituição do PSPN após a sanção da Lei 11.738/2008; como se configuram as principais dificuldades que obstaculizam o processo de instituição do PSPN; e como a instituição do PSPN valoriza os professores nos entes federados; e no terceiro, analisa-se a visão dos gestores educacionais municipais acerca de como vem sendo negociada a implementação dos planos de carreira dos professores pelo o governo com os entes federados; como devem ser estruturados (elementos estruturantes) os planos de carreira; e como as ações dentro dos planos de carreira valorizam os professores.

\section{$1^{\circ}$ Eixo: Envolvimento, experiências e ações em favor da instituição do Piso Salarial Profissional Nacional}

Neste primeiro eixo, faz-se uma análise dos depoimentos dos gestores educacionais municipais a respeito do envolvimento que mantiveram e as experiências e ações que realizaram no processo de instituição do PSPN. Foi solicitado que comentassem sobre o seu envolvimento na instituição do PSPN. Em resposta, assim se manifestaram:

Meu envolvimento com a instituição do piso salarial vem de longas datas. Já participei de muitos eventos, discussões e negociações. Nós da Secretaria Municipal de Santarém acompanhamos e participamos ativamente do processo de instituição do piso salarial por meio da Undime, nas discussões nacionais (Gestor Municipal 1).

Desde o princípio, estávamos convencidos desse direito. A luta, portanto, foi no sentido de saber se era possível pagar o piso salarial nacional e, evidentemente, conseguimos. O grande enfrentamento foi mais interno no campo político do que financeiro, porque no campo financeiro tivemos condição de pagar. [...] nosso município foi um dos poucos que se articulou para garantir o pagamento do piso salarial nacional dos professores, entendendo que ainda não cobre todas as necessidades reais do professor numa região como a nossa, mas já avançou (Gestor municipal 2).

Participei da briga para implementar o piso salarial aqui. [...] principalmente quando saiu a decisão do STF, gerando um certo desconforto nas contas das prefeituras, nos governos, porque se falava assim: como vou pagar o piso salarial, se não há recursos? Então, participei da estruturação do plano de carreira, quando tive a oportunidade de colocar o piso salarial nacional no plano, com a devida atualização 
das Tabelas. A briga foi boa, mas, graças a Deus, conseguimos colocar na reformulação do plano de carreira do município a questão do pagamento do piso salarial (Gestor municipal 3).

Os comentários dos gestores municipais, a sua militância em favor da instituição do piso salarial expressam, sobretudo, um determinado compromisso em lutar pela valorização dos professores da educação básica, tendo em vista a melhoria da qualidade da educação básica nos entes federados nos quais trabalham e no país. Nesse sentido, demonstram empenho, vontade e garra de lutar pela instituição do PSPN e dos planos de carreira nos dois municípios antes e, principalmente, após a decisão do STF, garantindo a implantação da Lei 11.738/2008. Ressalvam que o PSPN ainda não cobre todas as necessidades reais dos professores, mas foi um grande avanço na valorização dos docentes.

O empenho, a vontade e garra dos gestores muncipais de lutar e brigar pela instituição do PSPN e dos planos de carreira expressam um sentido mais amplo que é o de alavancar a construção das políticas públicas municipais, o desenvolvimento da educação como direito universal e subjetivo e avançar na garantia de acesso e na qualidade desse direito no país. E mais, acreditam que para haver ensino de qualidade nos municpios e no país, é preciso que os professores sejam valorizados por meio da instituição de um piso salarial forte e sólido. Entendem que a categoria de trabalhador da educação é parte dos demais trabalhadores para o desenvolvimento educacional, social e econômico dos municípios e do país.

Nos comentários dos gestores municipais encontram-se contradições em relação à instituição do PSPN. Os gestores municipais, tal como os gestores educacionais federais, desconectam a ordem capitalista vigente no país das suas trajetórias de militância em favor da instituição do PSPN. Abstraem a realidade concreta, econômica, política, social, ocultando o vínculo entre o trabalho que realizam e a sociedade brasileira real, concreta, historicamente situada. Assim, ocultam o fato de que o trabalho que realizam pode resultar em ações alienadas da realidade e solapadas pela ordem do capital, o que os leva a perderem de vista a direção do trabalho que realizam, mesmo que pareça ser em favor da valorização dos professores da educação básica.

Nesse contexto, Freitas analisa o que dispõe o documento Pátria Educativa da Secretaria de Assuntos Estratégicos da Presidência da República, particularmente o item que trata dos Diretores e do Professores:

[...] exemplo de ineficiência de soluções singelas e soladas é a insuficiência de aumento da remuneração de professores. [...] Há abundante evidência empírica para demonstrar que aumentar, ainda que substancialmente, o salário do professor não resulta, por si só, em melhoria do ensino, ainda que junto com muitas outras 
medidas, possa tornar a carreira atrativa (quando ela exista) muito atraente. (FREITAS, 2015, p. 3).

\section{Ao analisar o documento, Freitas afirma:}

O texto é dúbio. Não ajuda, mas ajuda. Não ajuda a resolver, mas ajuda a tornar atrativa a carreira. $\mathrm{O}$ texto tem apenas a função de preparar o leitor para aceitação da politica de bonificação como forma de diferenciar salários de tornar a profissão mais atrativa para quem se esforça e sacrifica. Como sempre acontece, a "abundante evidência empírica" existente segundo o documento, não é apresentada. Mas é fato que somente salário não propicia melhoria, automaticamente ao ensino. A razão é que o fenômeno educativo é multivariado e, portanto, depende de que se alterem simultaneamente os valores de múltiplas variáveis. (FREITAS, 2015, p. 3 ).

E afirma ainda:

à luz da grande evidência empírica igualmente disponível mostrando os limites da bonificação, a política de bônus não é recomendável. Sem salário digno, que não se limita a um piso ínfimo de 500 dólares não se coloca a questão de se aumento salarial é ou não uma solução para o ensino. Ele nem chega a ser digno e só por isso, necessita ser aumentado. Ignoram-se os dados da OCDE sobre o que se paga no mundo para professores em países com educação bem sucedida. A evidência empírica, quando convém, não é alegada. (FREITAS, 2015, p. 4)

Na afirmação de Freitas (2015), os efeitos da política de bonificação dos professores, considerada como base da reforma empresarial da educação, não são mais do que deletérios e praticamente nulos para a melhoria da educação pública. Assim, pode-se dizer que o Pátria Educadora é mais um documento oficial produzido para escamotear a potencialidade do trabalho dos professores nas escolas públicas, embora pareça ser em favor da valorização dos mesmos.

Ao abordar a questão da valorização dos professores da educação básica, Saviani também considera que:

[...] há dois pontos de estrangulamento referentes à duas dimensões articuladas na questão do magistério que precisam ser sanadas. $\mathrm{O}$ primeiro ponto diz respeito à necessidade de se instituir a carreira dos profissionais da educação aumentando significativamente o valor do piso salarial dos professores e estabelecendo a jornada do tempo integral e uma única escola no máximo $50 \%$ do tempo destinado a ministrar aulas. O restante do tempo será dedicado à preparação de aulas, correção dos trabalhos dos alunos, atendimento diferenciados aos alunos com mais dificuldades de aprendizagem, além da participação na gestão da escola. O segundo ponto consiste na necessidade de se criar uma rede pública consistente de formação dos professores ancorada nas universidades públicas. Isso é indispensável para corrigir uma grande distorção do processo de formação docente no Brasil [...]. (SAVIANI, 2014, p. 2)

Nessa linha de abordagem, Cury (2010) afirma que [...] a existência de um plano de carreira e de um padrão mínimo salarial é fundamental para tornar efetivo o Sistema Nacional 
de Educação, baseado na articulação e na cooperação entre os entes federados. A qualidade na educação não virá se não houver um desempenho melhor dos alunos, a qualificação dos professores e também melhores salários atrativos para o exercício da docência.

O empenho, a vontade e a garra dos gestores municipais de lutar pela instituição do PSPN e planos de carreira se afinam com o posicionamento dos autores no que diz respeito à necessidade de instituição do PSPN e dos planos de carreira, porém, a visão desses gestores carece de análise crítica a respeito do sentido de valorização implícito em documentos oficiais como Pátria Educadora, por exemplo, que minimizam a potencialidade do trabalho realizado pelos professores nas escolas públicas, propondo bonificação como valorização dos docentes. Os gestores municipais pouco percebem que suas ações se alinham ao propósito do Estado, que busca preservar a estrutura e o funcionamento do sistema do capital no país, contribuindo para a continuidade da alienação dos professores.

No $2^{\circ}$ eixo, aborda-se a visão dos gestores educacionais municipais sobre a instituição do Piso Salarial Profissional Nacional.

\section{Nacional \\ $2^{\circ}$ Eixo: Valorização por meio da instituição do Piso Salarial Profissional}

Neste segundo eixo, faz-se uma análise da visão dos gestores educacionais municipais a respeito de como vem sendo negociada a instituição do PSPN após a sanção da Lei 11.738/2008; como se configuram as principais dificuldades que obstaculizam o processo de instituição do PSPN; e como a instituição do PSPN valoriza os professores nos entes federados.

Perguntou-se aos gestores educacionais municipais: como vem sendo negociada a instituição do Piso Salarial Profissional Nacional? Em resposta, assim se manifestaram:

O diálogo e a transparência foram procedimentos fundamentais na negociação do piso salarial. Por meio das negociações compartilhadas, a nossa meta foi sempre chegar ao máximo possível, mas, logicamente, sem prejudicar também os investimentos tão necessários aqui na região, que conta com mais de 450 escolas e 62.000 alunos distribuídos em $22.000 \mathrm{~km}$ de rios, florestas, áreas de várzea, áreas de assentamentos, quilombolas e indígenas (Gestor municipal 1).

A negociação envolvendo as partes interessadas é a melhor forma de processar a instituição do piso salarial. Assim, a implementação do piso salarial no ano passado, em 2010, foi feita a partir de uma negociação com o sindicato dos professores, até se chegar à definição e acertos do melhor momento e do modo mais adequado de realizarmos o pagamento do piso salarial (Gestor municipal 2). 
O caminho mais adequado para se chegar a um consenso sobre a instituição do piso salarial é o diálogo entre as parte envolvidas. Assim conseguimos reformular o plano de carreira do nosso município com seus devidos pilares: salário inicial e formação. Na estruturação do plano de carreira, tive a oportunidade de colocar a importância do piso salarial nacional com a devida atualização das Tabelas (Gestor municipal 3).

Na visão dos gestores municipais, a negociação dialogada é a melhor forma para se processar a instituição do PSPN, porque propicia o envolvimento das comissões de professores, sindicatos de professores e técnicos das secretarias municipais da educação e de outros órgãos das prefeituras.

Ao apontarem a negociação dialogada como a forma mais adequada para se resolver os problemas que envolvem a instituição do PSPN nos municípios, os gestores municipais não atentam para o fato de que não é suficiente contrapor a negociação dialogada a um modelo de gestão autoritária. O exercício da negociação dialogada, democrática, aberta, transparente pode ser usado como uma excelente forma, um modo eficiente, um método eficaz de ocultação ideológica e de manipulação e alienação. As negociações baseadas na gestão democrática podem servir para desviar o foco principal do sentido da instituição do PSPN como ação política do Estado, por meio dos governos federal, estaduais e municipais, que continua sendo a de preservar e proteger a força do sistema do capital no país. Assim, deter o foco na gestão democrática, na relação dialógica nas negociações externas e no âmbito das escolas pode contribuir para escamotear as raízes dos problemas relativos à real valorização do trabalho realizado pelos professores. Só dialogar não basta! Não se deve esquecer que a democracia que vigora no sistema capitalista, de modo geral, é a democracia controlada pelos donos do poder econômico, político e ideológico.

Ainda neste segundo eixo, foi perguntado aos gestores educacionais municipais: como se configuram as principais dificuldades que obstaculizam o processo de instituição do Piso Salarial Profissional Nacional? Em resposta, assim se expressaram:

Mesmo considerando o diálogo como uma forma adequada para se negociar a implementação da Lei do Piso, porque é a maneira de resolver os problemas, aqui tivemos grandes dificuldades na condução das negociações porque a gente não trabalhou como queriam impor a Prefeitura à Secretaria de Educação. Aqui a gente precisa ainda aprender a dialogar para resolver os problemas educacionais em conjunto (Gestor municipal 1).

A maior dificuldade foi ter que implantar a Lei do Piso mediante a real situação orçamentária do município. A receita do município teve que ser repensada (Gestor municipal 2).

Para que se conseguisse receber os valores retroativos decorrentes da instituição do piso salarial profissional nacional, a classe dos professores se uniu e fomos pra briga. Foram vários problemas enfrentados, mas o mais difícil foi realmente a 
questão do pagamento do piso conforme está disposto na Lei 11.738/2008 (Gestor municipal 3).

$\mathrm{Na}$ visão dos gestores municipais, a maior dificuldade para se implantar a Lei 11.738/2008, que institui o PSPN, é a questão orçamentária e financeira dos municípios. Ao mesmo tempo, apontam a tentativa da prefeitura de encaminhar as negociações ainda de forma autoritária, imposta, desconsiderando a necessidade de diálogo entre comissões de professores, sindicatos de professores, técnicos da Secretaria de Educação e da Prefeitura na condução da instituição do piso salarial e no contexto democrático que vive a sociedade brasileira, propicia a busca de pactos consensuados por meio do diálogo.

Ao apontarem a questão orçamentária e financeira como a maior dificuldade para a instituição do piso salarial profissional nos municípios, a visão dos gestores municipais se alinha à visão política do governo federal, da União, do Estado, que foca o salário dos professores o elemento principal da politica de valorização dos profissionais da educação básica, conforme regulamentado pela Lei 11.738/2008. A visão dos gestores municipais centrada na questão econômica e financeira contribui para da despontencialização do trabalho realizado pelos professores que, de fato, deveria ser visto como o elemento primordial da política de valorização dos professores.

Sobre o problema da tentativa da prefeitura de encaminhar as negociações ainda de forma autoritária, não basta somente alterar a forma de negociações, opondo o modelo de negociação democrática à cultura de gestão autoritária. A gestão democrática pode servir como mecanismo ideológico, desviando o foco sobre do principal elemento de valorização dos professores, que é o trabalho realizado nas escolas. Assim, a potencialidade do trabalho dos profissionais da educação básica continua sendo negada como categoria fundante do ser humano, enquanto as negociações dialogadas podem servir para envolver os sujeitos apenas num clima de euforia, alegria, participação.

Ainda neste segundo eixo, foi perguntado aos gestores educacionais municipais: como a instituição do Piso Salarial Profissional Nacional valoriza os professores nos entes federados? Dentre as respostas obtidas, destaca-se esta que, de certo modo, sintetiza as demais:

Antes da Lei do Piso, os professores eram bastante desvalorizados. Mas, após a decisão do STF, muita coisa mudou na vida dos professores e de suas famílias. Por exemplo, em janeiro de 2011 recebíamos um salário menor, inferior ao piso. Agora, em junho, efetivamos o último pagamento referente às diferenças anteriores, decorrentes da implantação do piso. Outro elemento considerado importante foi a questão de 1/3 da jornada de trabalho a qual já foi resolvida (Gestor municipal 3). 
A visão do gestor municipal 3 é objetiva com relação à instituição do PSPN, levando em conta que a Lei 11.738/2008 é um instrumento fundamental para se implantar a política de valorização dos professores nos entes federados. Afirma, categoricamente, que após a instituição do PSPN, "muita coisa mudou na vida dos professores e de suas famílias". Portanto, a ação política do Estado foi bastante postiva em favor da valorização dos professores da educação básica.

Ao ressaltar o efeito positivo do PSPN na vida dos professores e de suas famílias, o gestor mundcipal 3 deixa-se envolver pela ideologia do Estado que, ao promover essencialmente a valorização do salário dos professores, desvia o foco da potencialidade do trabalho realizado por eles nas escolas e em outros espaços educacionais.

A visão do gestor educacional municipal 3, não considera o trabalho como categoria fundamente dos professores como seres humanos. Sua visão se funde na perspectiva do Estado, que é a de aumentar o salário dos professores para que possam consumir mais no mercado, contribuindo para o funcionamento da economia capitalista vigente no país. Então, toda a positividade depositada na valorização dos professores por meio da valorização do PSPN consiste em contribuir para aumentar a circulação de maior quantidade de dinheiro no mercado.

Seguindo essa mesma linha de análise, aborda-se no $3^{\circ}$ eixo a visão dos gestores educacionais municipais sobre a implantação dos planos de carreira nos entes federados.

\section{Eixo 3: Implementação dos Planos de Carreira para os professores}

Neste terceiro eixo, faz-se uma análise da visão dos gestores educacionais municipais a respeito de como vem sendo negociada a implantação dos planos de carreira dos professores pelo o governo com os entes federados; como devem ser estruturados (elementos básicos) os planos de carreira; e como as ações dentro dos planos de carreira valorizam os professores. Foi perguntado aos gestores como vem sendo negociada a implantação dos planos de carreira dos professores pelo o governo com os entes federados? Em resposta, assim se manifestaram:

\footnotetext{
Aqui na Secretaria de Educação todas as negociações com o sindicato, com a prefeitura, com o governo estadual e com os órgãos do governo federal são feitas na base do diálogo, principalmente quando envolve recursos financeiros para os projetos e ações pedagógicas. Aqui a gente tem negociado o plano de carreira dos professores, principalmente com o sindicato. O piso salarial e a formação são os dois pontos mais importantes na estrutura do plano de carreira que a gente tem negociado (Gestor municipal 1).
} 
A questão do piso salarial e a formação são os dois aspectos principais a estrutura do plano de carreira dos professores. São aspectos negociados com a participação dos professores, dos gestores, dos dirigentes do sindicato. Na base da negociação temos resolvido diversos problemas da educação no município (Gestor municipal 2).

Aqui sempre que há algum tipo de problema envolvendo os professores, temos resolvido negociando conjuntamente com os governos municipal, estadual e federal. Negociamos o piso salarial no plano de carreira e assim os professores foram beneficados (Gestor municipal 3).

$\mathrm{Na}$ visão dos gestores municipais, as negociações para implantação dos planos de carreira dos professores nos municípios vêm sendo realizadas por meio do diálogo. Eles entendem que o diálogo tem sido a melhor forma de resolver os problemas que envolvem a educação básica nos municípios, entre eles, a implantação dos planos de carreira.

Os gestores municipais consideram a negociação dialogada como a melhor forma de negociação com as comissões de professores, sindicatos de professores e técnicos das secretarias municipais da educação e de outros órgãos das prefeituras. De fato, por meio do diálogo pode-se negociar e chegar aos pactos necessários ao andamento das políticas no campo da educação. Mas o diálogo tem sua validade e funcionalidade como meio e não como fim de uma ação concreta. No caso em tela, as negociações dialogadas são feitas em torno da implantação dos planos de carreira, mas qual o sentido, a finalidade dessa ação?

A visão dos gestores municipais recai mais sobre o meio, a forma, o método, ou seja, diálogo, quando o foco deveria ser sobre o significado da elaboração dos planos de carreira. Ao focarem o sentido do meio e não do fim da ação sobre a qual se negocia de forma dialogada, a visão desses gestores esconde o que deveria ser a finalidade das negociações dialogadas, isto é, a potencialidade do trabalho dos professores enquanto meio de emancipalos como seres humanos.

Ao focarem a implantação dos planos de carreira nos entes federados de forma descolada da realidade, as negociações contibuem para ocultar o sentido da ação política do Estado coordenada pela via Divape/Sase/MEC, que é a de melhor organizar um dos mecanismos de valorização salarial dos professores para aumentar a força do capital.

Ainda neste terceiro eixo, foi perguntado aos gestores educacionais municipais: como devem ser estruturados (elementos básicos) os planos de carreira? Em resposta, assim se expressaram:

Os elementos que a gente considera como pilares dos planos de carreira são o piso salarial e a formação. São principalmente estes dois elementos estruturantes que a gente coloca na mesa de negociação com o sindicato e as comissões de professores e técnicos da prefeitura. Tem outros elementos, mas esses são os indispensáveis (Gestor federal 3). 
São diversos elementos, mas aqui nós consideramos o vencimento inicial ou piso salarial e a formação como os principais. Além desses, as formas de promoção profissional, com perspectiva de crescimento salarial no futuro. Mesa de negociação (Gestor federal 2).

Nós conseguimos receber os valores retroativos decorrentes da Lei do Piso. Foi muita luta, mas a gente conseguiu. Por isso a gente considera o piso salarial como o principal elemento de valorização dos professores no plano de carreira (Gestor federal 3).

$\mathrm{Na}$ visão dos gestores municipais, o vínculo entre PSPN e formação, e vice-versa, contitui a estrutura os planos de carreira nos entes federados. Entendem que somente tendo um salário potente nos planos de carreira compatível com a formação, os professores se sentirão motivados ao exercício do magistério e valorizados como profissionais. Outros elementos podem até ser negociados e incluídos nos planos de carreira, mas esses são os indispensáveis.

Na visão dos gestores municipais há positividade quanto aos elementos básicos que mais valorizam os professores nos planos de carreira. Mas há um ponto cego na visão positiva desses gestores: o sentido que envolve a ideia de formação e valorização na própria positividade dos elementos básicos apontados pelos gestores.

$\mathrm{Na}$ perspectiva dos gestores municipais, o vínculo entre salário e formação é considerado altamente benéfico à valorização dos professores. Mas sua visão pode demonstrar aparência quanto à valorização professores, pois, “[...] este fenômeno consiste em pseudoconcreticidade, fenômeno que mostra parcialmente a realidade, escondendo nela, uma essência a ser desvelada". (KOSIK, 1986, p.13). Esse modo de ver a realidade, ou seja, de forma aparente, alinha-se ao modo de implantação das políticas educacionais pelo governo. $\mathrm{O}$ governo considera as políticas educacionais voltadas para a formação, qualificação profissional, piso salarial, planos de carreira como elementos indispensáveis à valorização dos professores da educação básica, em função da qualidade da educação nas escolas, mas deixa de lado ou não considera o sentido da potencialidade do trabalho realizado pelos professores nas escolas. Essa situação foi pior no governo do Presidente Fernando Henrique Cardoso, e mereceu mais atenção nos governos do Presidente Luiz Inácio da Silva e da Presidente Dilma Rousseff.

No governo do Presidente Fernando Henrique Cardoso a desconsideração para com a potencialidade do trabalho realizado pelos professores foi muito pior, embora o ex-ministro Paulo Renato Souza, ao avaliar a educação no país, ressaltou o tratamento dado aos professores no governo Fernando Henrique como sendo muito favorável: 
[...] a qualidade da educação melhorou, mas ainda deixa a desejar. E os instrumentossão conhecidos: é continuar a melhorar a qualificação dos professores. Em 1995, os professores da primeira a quarta série eram leigos numa poproporção de um em cada quatro, $25 \%$. Hoje são só 65 no mesmo segmento. Se você olhar o conjunto do ensino básico, em 1995 tinham só 47\% de professores com nível superior. Hoje, estamos perto de $60 \%$, embora ainda tenhamos $40 \%$ sem nível superior. É preciso continuar isso (PORTAL CM CONSULTORIA, 2003).

Continua afirmando:

E tem havido tímida valorização salarial. O Fundef significou uma melhoria importante. Na média nacional, o salário dos professores entre 98 e 2001 teve um aumento nominal de $30 \%$. No Nordeste foi de $70 \%$. Os salários ainda estão defasados, mas houve melhoria e tem que continuar [...] (PORTAL CM CONSULTORIA, 2003)

Na afirmação de Paulo Renato Souza, o governo Fernando Henrique Cardoso, chegou a promover certa melhoria no campo da educação. Mas, de fato, a promoção desse governo no campo da eeducação deixou muito a desejar, chegando a romper o Acordo Nacional de Educação para Todos que deu origem ao Pacto pela Valorização do Magistério e Qualidade da Educação, que decorreu do diálogo do governo Itamar Franco com as instituições Conselho Nacional dos Secretários de Educação (Consed), União Nacional dos Dirigentes Municipais de Educação (Undime), Conselho de Reitores das Universidades Brasileiras (Crub), Fórum dos Conselhos de Educação, a CNTE e diversas instituições da sociedade civil (VIEIRA, 2010, 42).

No Acordo rompido pelo governo do Presidente Fernando Henrique Cardoso constava que:

Para obter eqüidade e qualidade na educação, faz-se imprescindível a implantação de um piso salarial profissional do magistério de, no mínimo R \$ 300,00 (trezentos reais), com garantia de seu poder aquisitivo em $1^{\circ}$ de julho de 1994 [...] O Fórum Permanente do Magistério providenciará estudos que deverão indicar os mecanismos de implantação do Piso Salarial Profissional Nacional, do novo regime de trabalho e dos Planos de Carreira, dos montantes necessários para viabilizá-los, das formas de articulação entre as diversas instâncias governamentais, das novas fontes de financiamento para os proventos dos inativos, valorização do pessoal técnico-administrativo e de apoio das atividades educacionais no cenário do Acordo Nacional de Educação para Todos. (BRASIL, 1994, p. 22-23)

Na avaliação de Vieira (2010), o Pacto pela Valorização do Magistério não resistiu à força das políticas neoliberais implantadas no governo Fernando Henrique Cardoso. De fato, as duas gestões do referido governo tiveram como foco o estímulo à privatização e à municipalização da educação, o encolhimento do Estado brasileiro em relação à eduação superior e tecnológica e a redução de direitos dos trabalhadores, para atender aos interesses dos organismos internacionais. Mattos (2011) lembra que essa influência dos organismos 
internacionais pode ser constatada em documento que se tornaram públicos pelo Congresso Nacional, em 1998, contendo as estratégias adotadas por tais organismos para monitorar os empréstimos ao país. A discussão de assistência ao país do Banco Interamericano de Desenvolvimento (BID) e na mesma linha do Banco Mundial. Dessa forma, o PSPN não tinha as mínimas condições de prosperar (VIEIRA, 2010, p. 42).

No governo do Presidente Luiz Inácio Lula da Silva criaram-se as condições objetivas para a instituição do PSPN, mas a estratégia de assistência do país por parte dos organismos internacionais foi ajustada na nova conjuntura. Por isso, há que se questionar sobre a visão dos gestores educacionais municipais a respeito da relação entre planos de carreira e formação que é exigida dos professores. Em geral, a qualidade da formação dos professores não é discutida e levada em conta nas negociações acerca dos planos de carreira, mas o que conta é apenas a titulação como símbolo da formação necessária para atender as exigências formais e não substanciais.

Além disso, a visão dos gestores municipais privilegia a meritocracia em detrimento da real sentido do trabalho realizado pelos professores. A formação dos professores é considerada como um mérito em si, o que os leva a merecer somente valorização salarial. Essa relação acaba sendo perniciosa aos professores porque, além de colocá-los na posição de peças importantes na legitimação da lógica de assistência dos organismos internacionais ao país, alavancando a ordem capitalista, desvia o foco principal que é o valor do trabalho realizado pelos professores nas escolas públicas.

Ainda neste terceiro eixo, foi perguntado aos gestores educacionais municipais: como as ações dentro dos planos de carreira valorizam os professores? Em resposta, assim se expressaram:

Além do piso salarial e da formação, tem que constar mecanismos claros de
promoção por tempo de serviço, perspectiva de futuro, condições de trabalho,
jornada de trabalho compatível (Gestor educacional municipal 1).
O salário é o principal e valoriza os professores porque assim podem suprir suas
necessidades e de seus familiares. Podem comprar livros, computador, viajar e
cuidar da saúde. Isso tudo tem que ser negociado com o sindicato dos professores e a
prefeitura (Gestor educacional municipal 2).
O salário e a formação são os principais; depois vem a progressão por tempo de
serviço, licença prêmio a cada cinco anos a questão do mérito por meio do $14^{\circ}$
salário para aquelas escolas que atingem o melhor IDEB (Gestor educacional
municipal 3).

Os gestores educacionais municipais apontam outros elementos para valorização dos professores, tais como promoção por tempo de serviço, perspectiva de futuro, condições de 
trabalho, jornada de trabalho compatível, licença prêmio, e o recebimento por mérito em forma de pagamento salarial.

Entendem que, além da conexão entre piso e formação, os demais elementos fortalecem o eixo dos planos de carreira e, desse modo, os professores se sentem mais valorizados. Nessa perspectiva, quanto mais elementos forem agregados a esse eixo, mais valorizados se sentirão os professores na perspectiva de um futuro promissor. Portanto, a lógica é quantitativista ao considerarem que, quanto mais elementos forem inseridos nos planos de carreira, maior será o grau de valorização dos professores pelo trabalho que realizam nas escolas.

A visão dos gestores municipais, guiada pela lógica quantitativista esconde a potencialidade da valorização social dos professores. Nesse modo de ver, desaparece a dimensão qualitativa que consiste na valorização da autorerrealização dos professores como seres humanos e não apenas como profissionais. Valorizar somente a dimensão profissional dos professores, por meio da inserção do maior número de elementos nos planos de carreira, contribuindo para valorizá-los dentro da lógica da ordem capitalista vigente no país, despotencializa o trabalho que realizam nas escolas e em outros ambientes educacionais.

\subsubsection{Bloco C: Dirigentes de entidade nacional e sindicais municipais de professores}

$1^{0}$ Eixo: Envolvimento, experiências e ações em favor da valorização dos professores da educação básica, por meio da instituição do Piso Salarial Profissional Nacional

Neste primeiro eixo, são apresentados os depoimentos explicitados pelos dirigentes de entidade nacional e sindicais municipais a respeito do seu envolvimento, suas experiências e ações em favor da instituição do Piso Salarial Profissional Nacional. A rigor, falam do trabalho que vêm realizando em favor da implantação da Lei 11.738/2008.

Assim, solicitou-se aos dirigentes de entidade nacional e sindicais municipais que fizessem comentários sobre o seu envolvimento com a instituição do PSPN. Em resposta, assim se manifestaram:

O meu envolvimento com o processo de instituição do Piso Salarial Profissional Nacional deu-se em razão da minha longa mitância sindical em defesa dos direitos dos profissionais da educação pública. O que posso dizer sobre as minhas 
experiências com a questão do piso salarial é que a implantação dessa lei não tem sido fácil. Temos vivido momentos muito difíceis e uma incompreensão muito grande, em proporções diferentes, por parte das autoridades estaduais, municipais e, em alguns casos, até federais (Dirigente de entidade nacional 1).

O piso salarial é uma luta nacional e aqui em Santarém não ficamos fora desse contexto. Quando assumimos o sindicato, em julho de 2011, foi o período em que o STF deu um parecer favorável à implementação do piso salarial em todo o Brasil. Aqui em Santarém nos organizamos como categoria e implantamos a Lei 11.738 de 2008 a partir de setembro de 2011 (Diirigente sindical municipal 1).

O nosso envolvimento com a questão educacional tem sido bem considerado. Em nosso sindicato tem duas classes distintas: os professores e o pessoal técnico administrativo, envolvendo todos os funcionários no campo da educação. $\mathrm{O}$ piso salarial, desde que foi sancionado, passou a ter uma importância muito grande na valorização dos professores, apesar de que alguns municípios ainda não funcionam assim. Conforme a CNTE, ainda há municípios em que os professores não recebem o piso. Aqui, a gente teve uma briga relativamente grande para conseguir a implantação do piso. Mas, agora, graças a Deus, estamos bem tranquilos com relação à essa questão (Dirigente sindical municipal 2).

A visão dos dirigentes de entidade nacional e sindicais municipais de professores expressa um empenho em defesa dos direitos dos profissionais da educação pública, especialmente em favor da instituição do PSPN. Ressaltam que a luta pela instituição do PSPN carrega uma falta de compreensão muito grande, em proporções diferentes, por parte das autoridades estaduais, municipais e, em alguns casos, até federais. Mas, apesar das dificuldades, a conquista do PSPN, desde que foi instituído, passou a ter uma importância muito grande na valorização dos professores mesmo sendo insuficiente. Assim, o envolvimento, as experiências, as ações desses dirigentes são consideradas positivas dentro de suas perspectivas em favor da valorização dos professores.

O que não se percebe na visão dos dirigentes é a preocupação com o vínculo do trabalho que vêm realizando em favor da instituição do PSPN com o contexto social, político e econômico da sociedade brasileira. Em outros termos, os dirigentes situam a importância da valorização salarial dos professores dentro da realidade brasileira, mas não conseguem perceber a direção do trabalho que realizam em favor do PSPN de forma alinhada à ação do Estado. Assim, o seu envolvimento, as suas experiências e ações se mostram como ações concretas, politicamente corretas, entretanto, desconectados da realidade capitalista no país.

No capitalismo é o mercado que orienta a economia. A chamada livre concorrência e a a competição na venda dos bens e serviços. A concorrência em que todos apoarentemente são livres para produzir, comprar, vender, fixar preços etc, não existe, pois é tudo não passa de ideologia para ocultar a realidade concreta. Em verdade, o mercado é dominado por grandes grupos que expandem cada vez mais sua área de atuação por meio de fusões, 
incorporações e outros modos de ampliação de negócios, eliminando pequenos e médios concorrentes.

Neste tipo de sistema econômico, os trabalhadores são explorados, ou seja, jamais os salários correspondem ao valor de trabalho e experiência, sempre recebem menos do que se produzem, aparentemente o salário cobre o que consomem. São inúmeras as frustrações vivenciadas pelos trabalhadores dentro do mundo do trabalho. As relações entre o ser humano e o trabalho geralmente estão bloqueadas pelas estruturas das organizações do sistema capitalista que visa apenas ao lucro, esquecendo-se dos seres humanos como sujeitos de transformação da realidade social.

Ao desconectarem o trabalho que realizam da realidade concreta, os dirigentes de entidade nacional e sindicais municipais de professores escondem a estrutura da sociedade brasileira de classes e a função do Estado de preservar e legitimar o poder da classe dominante hegemônica. Escondem o sentido da ação política do Estado na instituição do PSPN, que é de empoderar econômica e financeiramente os professores, a fim de que possam contribuir possam consumir mais mercadorias no mercado capitalista e, assim, contribuir para fomentar o funcionamento da ordem econômica vigente no país. Assim, o pagamento do PSPN nos municípios brasileiros pode significar simplesmente mais dinheiro em circulação no mercado local e regional e menosvalorização do trabalho dos professores nas ecolas.

No $2^{\circ}$ eixo, aborda-se a visão dos dirigentes de entidade nacional e sindicais municipais sobre a valorização dos professores da educação básica por meio do PSPN.

\section{$2^{\circ}$ Eixo: Valorização por meio do Piso Salarial Profissional Nacional}

Este segundo eixo analisa as manifestações dos dirigentes de entidade nacional e sindicais municipais a respeito de como vem sendo negociada a instituição do PSPN após a sanção da Lei 11.738/2008; como se configuram as principais dificuldades que obstaculizam o processo de instituição do PSPN; e como a instituição do PSPN valoriza os professores nos entes federados. Foi perguntado aos dirigentes: como vem sendo negociada a instituição do Piso Salarial Profissional Nacional? Em resposta, assim se manifestaram:

A melhor maneira de resolver os problemas da educação é por meio do diálogo sério. Neste ano, um dos momentos em que isso aconteceu foi quando o percentual que estava estimado para reajustar o custo aluno não se concretizou. No meio do ano sofreu uma redução. O governo federal entendeu que só pode repassar a complementação de recursos para os municípios e estados que não atingirem o valor do custo aluno do FUNDEB. Na verdade, falta dinheiro na educação, 5\% do PIB brasileiro é pouco para financiar a educação que o nosso país precisa. Mas também 
tem muito problema de gerenciamento dos recursos (Dirigente de entidade nacional 1).

Aqui no município a gente resolve os problemas na área da educção por meio das negociações com os professores. O mesmo acontece com os órgãos da prefeitura, do Estado, do governo federal e outros órgãos. Assim, foi com a implantação do piso salarial após da determinação do STF em Brasília. Nós conversamos e chegamos a um consenso. O piso agora é um teto salarial nacional que vale para todos os municípios (Dirigente sindical municipal 1).

A gente já aprendeu que sem diálogo não existe negociaçã; e não tendo negociação, os mais prejudicados são os professores. Por isso a gente negociou e continua negociando com os gestores a melhoria dos planos de carreira. Com a elaboração do plano de carreira a situação ficou mais fácil para que a gente cobrasse da Secretaria e, consequentemente, ela cobrasse do governo o cumprimento com o piso (Dirigente sindical municipal 2).

$\mathrm{Na}$ visão dos dirigentes de entidade nacional e sindicais municipais, o meio mais adequado para se alcançar a instituição do PSPN nos entes federados é o diálogo. É por meio do diálogo que o PSPN e outros elementos de valorização dos professores vêm sendo negociados com os professores, órgãos da prefeitura, dos estados e do governo federal. Os resultados alcançados têm sido muito favoráveis para a categoria de professores.

Ao apontarem o diálogo como meio apropriado para as negociações sobre temas voltados para a valorização dos professores, a visão dos dirigentes se alinha à forma de gerenciamento considerada mais adequada para as escolas na atualidade. Essa forma de gerenciamento se alinha ao modelo de Estado neoliberal, que transfere aos municípios atribuições que são suas. Daí o interesse do Estado em estabelecer como modelo de gerenciamento nas escolas e em outros espaços da sociedade civil como forma apropriada para o atual momento democrático que vive o país.

Ainda neste segundo eixo, foi perguntado aos dirigentes de entidade nacional e sindicais municipais: como se configuram as principais dificuldades que obstaculizam o processo de instituição do Piso Salarial Profissional Nacional. Em resposta, assim se expressaram:

A maior dificuldade é o financiamento da educação. Os estados e municípios têm dificuldade de caixa para arcar com as despesas da educação. O governo precisa estabelecer como sanar essa dificuldade, dizer como as negociações, as pactuações podem ser financiadas. O governo deve arcar com essa responsalidade (Dirigente de entidade nacional 1$)$.

A maior dificuldade foi a adequação do piso salarial de acordo com a Lei do Piso. Foi preciso muita negociação por causa das condições financeiras do município. Mas, graças a Deus, a gente conseguiu fazer boas negociações e o piso está sendo pago (Dirigente sindical municipal 1). 
São diversos fatores que atrapalham a instituição do piso salarial aqui no município, mas a questão do contrato temporário, por falta de concurso, é séria. Por um lado, os professores se sentem prejudicados porque os recursos que é destinado ao pagamento deles acaba sendo também para os temporários; e por outro lado, os temporários trabalham e querem os mesmos direitos dos professores efetivos (Dirigente sindical municipal 2).

$\mathrm{Na}$ visão dos dirigentes de entidades nacional e sindicais municipais, a maior dificuldade para instituição do PSPN nos entes federados envolve a questão orçamentária e financeira. Entendem que os entes federados sempre estão enfrentando situações críticas, em razão de medidas econômicas que levam à redução da arrecadação de impostos, especialmente daqueles que dependem dos fundos de participação. Aqueles que não têm uma economia forte, aqueles que não têm uma boa arrecadação de ICMS e que dependem fortemente dos repasses constitucionais, esses sempre estão vivendo problemas que impactam no pagamento do PSPN.

Entendem que a maior dificuldade na instituição do PSPN está na fragilidade econômica dos entes federados. Soma-se a esse problema a questão do contingenciamento dos recursos destinados à educação. O MEC, por força da lei, faz uma complementação do PSPN. Essa complementação representa $10 \%$ da complementação total que o MEC faz no FUNDEB, mas isso não é suficiente para resolver o problema financeiro dos estados e municípios.

Com a aprovação da Lei 11.494/2007, que regulamentou o Fundeb, a questão da valorização profissional continuou central. Nesse sentido, passou a especificar as responsabilidades de estados e municípios com a política de valorização dos profissionais da educação. A referida Lei, em seu art. 41, definiu que o poder público deveria fixar, em lei específicifica, até 31 de agosto de 2007, o Piso Salarial Profissional Nacional para o profssionais do magistério público da educação básica (BRASIL, 2007).

$\mathrm{O}$ art. 22 da Lei supracitada garante a remuneração dos docentes assim determinado: "pelo menos $60 \%$ (sessenta por cento) dos recursos anuais totais dos Fundos serão destinados ao pagamento da remuneração dos profissionais do magistério da educação básica em efetivo exercício na rede pública” (BRASIL, 2007).

Assim, a subvinculação de aporte dos recuros (60\%) do Fundeb para a remuneração dos profissionais do magistério apresenta-se como importante processo de construção de uma política de valorização salarial do magistério, porém não o suficiente. Cabe, pois, aos gestores estaduais e municipais aplicarem outros recursos em educação, inclusive parte dos $25 \%$ conforme dispõe a CF de 1988 e outras fontes como o salário educação, subvenções e operações de crédito. (BRASIL, 2007). 
Nesse contexto, ao apontarem a questão financeira como a maior dificuldade para a instituição do PSPN e pagamento do salário dos professores temporários, os dirigentes se alinham à visão do Estado, que é a de valorizar os professores somente por meio de pagamento de salários. De fato, alinham-se ao que dispõe a Lei 11.738/2008, que instituiu o PSPN para os profissionais do magistério público da educação básica. Com isso, percebe-se que, embora pareça que a visão dos dirigentes seja diferente e antagônica à visão dos governos federal e estaduais, de fato, todos os sujeitos envolvidos na instituição do PSPN têm o mesmo objetivo, que é valorizar econômica e financeiramente os professores e, assim, contribuir para a manutenção da ordem capitalista vigente no país. Daí a relevância das negociações dialogadas, das pactuações firmadas entre dirigentes sindicais e gestores dos entes federados para acomodação dos interesses do mercado nos municípios.

Desse modo, pode-se dizer que a visão dos dirigentes de entidades nacional e sindicais municipais valoriza o salário dos professores, mas despotencializa o trabalho que realizam nas escolas e nem os professores como seres humanos.

Ainda neste segundo eixo, foi perguntado aos dirigentes de entidade nacional e sindicais municipais: como a instituição do piso salarial nos entes federados valoriza os professores? A Lei do Piso estabelece que o piso salarial deve ser aplicada à carreira profissional
de professor. O piso é a base da carreira. O piso como está hoje ainda é pouco, mas
deve evoluir futuramente. E a carreira precisa valorizar o professor. O piso no plano
de carreira é a garantia da valorização dos professores (Dirigente de entidade
nacional 1).

O piso é a base da valorização dos professores, por isso tem que ser um piso forte, para que o professor possa viver melhor e sustentar sua família. O professor precisa de condições boas de trabalho, de uma casa decente, de cuidar da sua saúde, de comprar alimentos, e essas coisas dependem de um salário bom (Dirigente sindical municipal 1).

Acho que o piso valoriza os professores porque o salário é que dá condições de comprar o que prcisam para viver e cuidar dos seus familiares, esposa e filhos. $\mathrm{O}$ salário é a base de tudo (Dirigente sindical municipal 2).

$\mathrm{Na}$ visão dos dirigentes de entidades nacional e sindicais municipais, o PSPN é o elemento principal de valorização dos professores nos planos de carreira. Ele propicia condições aos professores para sustentarem suas famílias e a si mesmos. Eles consideram que o PSPN ainda é baixo, mas acreditam na sua evolução gradual e, desse modo, esperam que os professores sejam remunerados de forma equivalente às profissões que exigem o mesmo tempo de escolarização e responsabilidade similar no trabalho. 
Os dirigentes entendem que cada vez mais os professores estão assumindo muitas responsabilidades e, por conta disso, devem ser bem remunerados. Ou seja, o trabalho que realizam deve ser bem pago, para que possam comprar os bens que necessitam e possam viver bem com seus familiares. Assim, na visão dos dirigentes, o salário é tudo.

Ao apontarem o PSPN como o elemento principal na valorização dos professores, os dirigentes valorizam a remuneração dos docentes para acompanhar o aumento de atribuições e exigências que eles assumem atualmente em termos de formação e de demandas escolares que são cada vez maiores. Na perspectiva dos dirigentes, na mesma proporção em que as exigências e responsabilidades dos professores se ampliam, a valorização salarial dos professores também deveria aumentar.

Os argumentos dos dirigentes pareçam convincentes, mas neles existem contradições. Consideram o PSPN como a base de toda a valorização dos professores e, ao mesmo tempo, encobrem o que há de mais significativo em suas vidas, que é o trabalho como processo de autorrealização e emancipação humana. Os dirigentes não se dão conta de que, embora não pareça e talvez nem queiram que seja assim, mas acabam contribuindo para minimizar a potencialidade do trabalho dos professores em favor da valorização dos mesmos, focando, essencialmente, o elemento salário.

Daí o contínuo sentimento de desmotivação por parte dos professores com relação à participação nas ações dos sindicatos. Os sindicatos não atentam verdadeiramente para a ocorrência de situações nefastas vivenciadas pelos professores no ambiente de trabalho; para o não reconhecimento do seu trabalho por parte dos pais, alunos, direção da escola e dos próprios colegas; para a perda de autoridade diante dos alunos; para a frustração decorrente da falta de reconhecimento do trabalho, do uso do tempo ou da falta dele para atividades que consideram importantes, enfim, da autonomia e pouca liberdade no trabalho. Essa realidade impacta negativamente na autoestima dos professores, causando-lhes adoecimentos físicos, mentais e espirituais.

\section{Eixo 3: Implantação dos Planos de Carreira}

Neste terceiro eixo, foi perguntado aos dirigentes: como vem sendo negociada a implantação dos planos de carreira com os entes federados? Em resposta, assim se manifestaram: 
com a valorização dos professores no país. A carreira de professor tem que dar perspectiva de futuro, com mecanismos muito claros de promoção, que privilegiem o seu desempenho, sua atividade docente (Dirigente de entidade nacional 1).

Mantendo-se uma relação dialógica entre os sujeitos envolvidos. Dessa forma, por meio do diálogo, a gente tem conseguido negociar a solução para diversos problemas como a questão do pagamento do piso, a elaboração do plano de carreira, a formação dos professores, etc. O importante é que as relações entre as partes envolvidas sejam respeitosas e sérias com bons resultados (Dirigente sindical municipal 1).

Aqui a última versão do plano de carreira dos professores foi elaborada com a participação de todos os envolvidos: professores, sindicato, secretaria de educação e prefeitura. Assim, ficou mais fácil a aprovação do projeto na Câmara Municipal (Dirigente sindical municipal 2).

$\mathrm{Na}$ visão dos dirigentes de entidades nacional e sindicais municipais, o diálogo é o meio mais utilizado e frutífero nas negociações para implantação dos planos de carreira. Entendem que o diálogo propicia condições favoráveis à participação dos sujeitos envolvidos com a implantação dos planos de carreira e outras questões no campo da educação básica. Esse modo de proceder se alinha à perspectiva do pacto federativo, que preceitua participação, negociação, compromisso político e troca de apoio técnico entre os entes federados.

Ao ressaltarem o diálogo como ferramenta apropriada para se alcançar resultados efetivos nas negociações que envolvem professores, sindicatos, secretarias de educação estaduais e municipais, prefeituras municipais, a visão dos dirigentes, de certo modo, ora alinha-se ao modelo de gerencialismo que enfatiza a profissionalização e o uso de práticas de gestão dos setor privado, decorrente do governo neoliberal do ex-presidente Fernando Henrique Cardoso, ora à administração pública societal que enfatiza a participação social e procura estruturar um projeto politico que repense o modelo de desenvolvimento brasileiro, a estrutura do aparelho do Estado e o paradigma de gestão, enfatizando inciativas locais de organização e gestão pública (De Paula, 2005). Essa é a maneira ambígua de buscar alternativas para solucionar os problemas envolvendo as esferas federal, estadual e municipal.

$\mathrm{Na}$ visão dos dirigentes, há um procedimento de valorização de caráter democrático do diálogo, propiciando a participação dos sujeitos na condução do processo de negociação das questões pertinentes à valorização dos professores, mas ao ressaltarem a dimensão democrática do diálogo, acabam deixando de lado a dimensão dialética no processo de negociação dialogada em que os segmentos têm poderes diferentes. E, desse modo, escondem o conflito latente, imanente na relação dialógica entre os sujeitos que participam das negociações. As pactuações poderiam ser 
processadas como sínteses resultantes de relações conflituosas, de um movimento de posições contrárias e abertas à novas negociações.

Se esse movimento conflituoso fosse explicitado, os dirigentes poderiam assumir uma postura em favor da valorização do trabalho dos professores, da emancipação humana dos docentes e não apenas promover os ajustamentos e conformações para atender aos interesses dos governos federal, estadual e municipal, na convicção de estarem, de fato, promovendo a valorização dos professores nas escolas públicas.

Ainda neste terceiro eixo, foi perguntado aos gestores dirigentes de entidade nacional e sindicais municipais: como devem ser estruturados (elementos estruturantes) os planos de carreira? Em resposta, assim se expressaram:

\begin{abstract}
A valorização docente possui três dimensões: salarial, formação e condições de trabalho. Ou seja, o salário, a formação e as condições de trabalho são aspectos incluídos na valorização docente. Assim, um bom exercício profissional encontra-se ligado também à valorização social da profissão. Essa valorização pode incluir o respeito que a figura do professor deve receber, ou seja, ao status que a sociedade deve direcionar a esse profissional pela atividade que exerce e ainda ter autonomia suficiente para executar suas ideias e tarefas de forma satisfatória (Dirigente de entidade nacional 1).
\end{abstract}

Colocando a questão do salário e formação no centro das negociações. A criação do Plano de Cargo, Carreira e Remuneração - PCCR decorreu da luta sindical desde 2002 e continuou na nossa gestão. Antes os profissionais queriam ser bem remunerados, mas não tinham titulação, uma graduação. Santarém hoje é um campo minado de universidades e isso impacta na formação dos professores. Nesse sentido, o PCCR é uma arma para assegurar a valorização dos profissionais, pois, assim, o nível 1 - magistério ganha o piso salarial; progressão para o graduado, isto é, $60 \%$ de gratificação, que não ocorre por meio de concurso; progressão das classe A até $\mathrm{G}$, sendo de classe para outra a cada três anos, com ganho de $3 \%$ no salário; gratificação de $5 \%$ por quinquênio. Então, numa perspectiva de futuro, os profissionais percebem que podem evoluir profissionalmente, dependendo da titulação adquirida. Hoje, a maioria dos profissionais recebe de $\mathrm{R} \$ 2.200,00$ (dois mil e duzentos reais) a $\mathrm{R} \$ 5.000,00$ (cinco mil reais). A valorização desses profissionais é baseada na Lei 18.248, o PCCR, aprovada pela Câmara Municipal. Assim, eu acredito que dentro de dois anos e meio, em Santarém, não teremos mais profissionais apenas com magistério, exceto aqueles que estão próximos a se aposentar ou não querem mais estudar. O nível 1- magistério - referência do piso salarial nacional não vai mais ter validade em Santarém, porque a maioria desses profissionais estará do nível 2 pra frente. O PCR é a referência de valorização financeira dos profissionais (Dirigente sindical municipal 1).

Vinculação entre formação e ascensão salarial. Essses dois aspectos são os elementos básicos dos planos de carreira (Dirigente sindical municipal 2).

$\mathrm{Na}$ visão dos dirigentes de entidades nacional e sindicais municipais, os elementos estruturantes dos planos de carreira são o PSPN, formação e condições de trabalho. Sem esses elementos não se pode falar em valorização dos professores. 
Os dirigentes entendem que uma carreira bem estruturada valoriza os professores no presente e permite que os profissionais projetem o seu futuro, tenham perspectiva de trabalho e de vida. Entendem também que ainda há muito a avançar na implementaçõs dos planos de carreira, considerando que são milhares de entes federados no país, envolvendo municípios, estados e Distrito Federal, e cada um deles, nos marcos do pacto federativo, tem autonomia para gerenciar seu plano de carreira.

No entendimento dos dirigentes existe uma visão ideológica que consiste em enquadrar os professores num processo de aparente valorização, por meio da implantação dos planos de carreira. Porém, os planos de carreira estruturados essencialmente nos elementos salário, formação e condições de trabalho são mecanismos que, ao mesmo tempo, contribuem para simplificar o sentido de valorização dos professores, que é o trabalho realizado por eles nas escolas. Os planos de carreira operacionalizam o que dispõe a Lei 11.738/2008, implantados sob a orientação da Sase/MEC dentro da visão do governo vigente, sem levar em conta a realidade brasileira em conflito.

Ainda neste segundo eixo, foi perguntado aos dirigentes: como as ações dentro dos planos de carreira valorizam os professores? Em resposta, assim se expressaram:

O Piso Salarial Profissional Nacional é a base da carreira. Mas é preciso que a carreira tenha mecanismos claros de promoção, perspectiva de futuro, que valorize o ingresso por concurso público, para evitar essa enormidade de professores contratados temporariamente (Dirigente de entidade nacional 1).

O piso salarial nacional é um teto para os profissionais do magistério. Com o plano de carreira implementado, fica mais fácil a gente envolver os professores e fortalecer a categoria para reivindicar os seus direitos. Foi assim na última negociação que tivemos aqui com a secretaria de educação. Assim fica mais fácil lutar por outras questões mais pontuais, por exemplo, a realização de concursos. Em 2008, tivemos um concurso, mas como não pudemos acompanhar a sua elaboração, o resultado foi um fracasso (Dirigente sindical municpal 1)

A relação entre formação e ascensão salarial valoriza os professores nos planos de carreira. Esssa relação traz vantagens para os professores, por isso os professores estão procurando fazer cursos e ter títulos de graduação, pósgraduação para que possam mudar de padrão salarial na carreira (Dirigente sindical municipal 2).

$\mathrm{Na}$ visão do dirigente sindical municipal 1, existe um equívoco ao afirmar que "o piso salarial nacional é um teto para os profissionais do magistério". A Lei $11.738 / 2008$, em seu art. $2, \S 1^{\circ}$, assim dispõe:

O piso salarial profissional é o valor abaixo do qual a União, Estados, Distrito Federal e Municípios não poderão fixar o vencimento inicial das Carreiras do 
magistério público da educação básica, para a jornada de, no máximo, 40 (quarenta) horas semanais. (BRASIL, 2008).

A afirmação do dirigente sindical 1 não atenta para o que regulamenta a Lei do Piso, ou seja, o PSPN não é um teto para os profissionais do magistério, mas a remuneração inicial que deve ser inserida nos planos de carreira, ou seja, é piso e não teto.

Na visão dos dirigentes de entidades nacional e sindicais municipais, o PSPN é o elemento que mais valoriza os professores nos planos de carreira. E valoriza mais ainda se relacionado com o nível de formação dos professores. Os professores ascendem salarialmente na mesma proporção que evoluem em formação básica e continuada. Uma vez assegurado esse mecanismo, outras questões mais pontuais podem ser negociadas e inseridas nos planos de carreira.

$\mathrm{Na}$ visão dos dirigentes, carreira pressupõe que o ingresso se dê por concurso, que seja levado em conta o que o professor produz, o seu desempenho em sala de aula. Por isso o plano de carreira precisa ser aberto, permitindo que todos possam alcançar as referências salariais e de formação superiores. Por isso falar de valorização dos professores implica, necessariamente, na instituição de um PSPN forte e no aprimoramento da formação inicial e continuada.

$\mathrm{Na}$ perspectiva dos dirigentes, a ênfase dada é na relação salário-formação dos professores existem contradições. A implantação dos planos de carreira cria uma expectativa de valorização na vida dos professores e é considerada como divisor de águas na profissão. Com a implementação dos planos de carreira, os professores passam a ser mais valorizados, sentem que há perspectivas de valorização maior da profissão na linha do tempo, porém isso pode ser um mecanismo de valorização dos professores que legitima a estrutura do sistema capitalista e, ao mesmo tempo, uma conquista dos professores, um direito extraído do Estado.

Isto posto, o quadro 03 a seguir, apresenta um síntese da visão dos gestores educacionais federais e municipais, e de dirigentes de entidade nacional e sindicais municipais, de como vem sendo negociada a implementação do PSPN; como a instituição do PSPN valoriza os professores do magistério da educação básica; como os planos de carreira valorizam os professores do magistério da educação básica; e como se configuram as principais dificuldades que obstaculizam a instituição do PSPN e os planos de carreira. 
Quadro 03 - Síntese da visão dos gestores e dirigentes sobre a implementação do Piso Salarial Profissional Nacional e dos planos de carreira em favor da valorização dos professores da educação básic

Eixo 1. Como vem sendo negociada a implantação do Piso Salarial Profissional Nacional?

Por meio de negociação dialogada, compartilhada. O MEC, por intermédio da Sase, vem desempenhando um papel fundamental nas negociações. $\mathrm{O}$ piso salarial vem sendo inserido nos planos de carreira que, por sua vez, vêm sendo alinhados ao Plano Nacional de Educação. (Gestor Federal 1)

Por meio de negociações dialogadas entre os sujeitos envolvidos (sindicato, prefeitura, secretarias) no processo, mas, logicamente, sem prejudicar os investimentos necessários à execução de outras elementos da educação na região. (Gestor educacional municipal 1)

Por meio do diálogo sério nas negociações com os professores, órgãos da prefeitura, do Estado, do governo federal e outros órgãos, após a determinação do STF. (Gestor educacional municipal 2)

Eixo 2: Como a instituição do Piso Salarial Profissional Nacional valoriza os professores do magistério da educação básica?

Instituindo um salário potente na entrada da carreira. O salário é o principal, pois assim os professores podem suprir suas necessidades e de suas famílias, comprar livros, computador, viajar e cuidar da saúde. (Gestor educacional municipal 2).

Eixo 3: Como os planos de carreira valorizam os professores do magistério da educação básica? O piso salarial é a base dos planos de carreira, nos quais devem constar outros elementos de promoção, jornada de trabalho compatível, incentivos para aquisição de recursos pedagógicos e tecnológicos e perspectiva de futuro. (Gestor Federal 3)

Além do piso salarial, os planos devem contemplar mecanismos de promoção por tempo de serviço, condições de trabalho, jornada de trabalho, avaliação de desempenho e perspectiva de futuro. (Gestor educacional municipal 1)

O piso é a base da carreira e nela devem constar formas promoção, mecanismos de ingresso por concurso público, para evitar contratação temporária. (Dirigente de entidade nacional de professores 1)

Eixo 4: Como se configuram as principais dificuldades que obstaculizam a instituição do Piso Salarial Profissional Nacional e os planos de carreira?

Há problemas graves de caixa e fontes de financiamento, desvinculação entre piso salarial e carreira, entre piso e gestão da educação, ausência de um Sistema Nacional de Educação e grande número de docentes fora da escola. (Gestor Federal 1)

Entraves na condução das negociações, levando-se em conta a real situação econômica e financeira dos municípios. A receita do município teve que ser contingenciada. (Gestor educacional municipal 2)

No financiamento da educação, visto que os estados e municípios têm dificuldades de caixa para as despesas da educação. Os governos federal, estadual e municipal precisam pactuar as formas de financiar a educação. O governo federal deve coordenar esse processo. (Dirigente de entidade nacional 1)

Fonte: Elaborado pelo autor, a partir de entrevistas semiestruturadas.

O quadro 03 mostra que as visões dos gestores federais e municipais, e dos dirigentes de entidade nacional e sindicais municipais de professores sobre o processo de negociação para implantação do PSPN e dos planos de carreira, em favor da valorização dos professores 
do magistério da educação básica, não apresenta pontos divergentes ou antagônicos. Há uma concordância de todos quanto à relevância do PSPN enquanto elemento principal da política de valorização dos professores. Isto significa que o sentido de valorização docente equivale a valorização salarial dos professores, ou seja, valorização econômica e financeira. Por isso outros elementos como plano de carreira, formação, negociação dialogada, entre outros, são relevantes, desde que agregadas à instituição do PSPN.

O que o quadro 03 não mostra, mas deve ser explicitado? A alienação nas visões dos gestores e dirigentes. A instituição do PSPN como ação do Estado para valorizar os professores da educação básica, embora considerada positiva pelos gestores e dirigentes, dentro da ordem capitalista vigente no país, contibui para minimizar a potencialidade do trabalho dos professores e pouco considera o próprio professor como ser humano produtor do trabalho docente nas escolas públicas. 


\section{CAPÍTULO 3 - A implementação da Lei 11.738/2008: conquista, avanços e limites}

Como se configuram os avanços na instituição do Piso Salarial Profissional Nacional, por meio da Lei 11.738/2008, e em que consistem os limites que se impõem sobre a política de valorização dos professores da educação básica?

Este terceiro capítulo analisa as sugestões/propostas dos gestores educacionais federais e municipais, e dirigentes de entidade nacional de sindicais municipais de professores da educação básica consideradas como avanços na política de valorização dos professores da educação básica e, igualmente, as ações realizadas pela Sase do MEC, na busca por desocultar a minimização do trabalho docente que se esconde no modo de ver e proceder desses sujeitos. Além disso, propõe um balanço crítico da política de valorização dos professores da educação básica vigente e aponta dois caminhos alternativos ao desenvolvimento da mesma.

Nessa linha de ordenamento, o capítulo se estrutura em três itens. No primeiro item denominado Avanços: outros elementos e formas de valorização sugeridos pelos gestores educacionais federais e municipais, e dirigente de entidade nacional e sindicais municipais, em três blocos: Bloco A - gestores educacionais federais; Bloco B - gestores educacionais municipais; e Bloco C - dirigentes de entidades nacional e sindicais municipais de professores. O segundo ítem intitulado As perspectivas da Divape/Sase/MEC no envolvimento de e instrumentos para a implmentação do Piso Salarial Profissional Nacional analisa o trabalho que vem sendo realizado em favor da instituição do piso salarial e da implementação dos planos de carreira nos entes federados, considerados pela Divape/Sase/MEC como avanços na política de valorização dos professores da educação básica. No terceiro ítem denominado Propostas alternativas para a política de valorização dos profissionais do magistério público no contexto do segundo mandato do governo da Presidente Dilma Rousseff explicita-se duas formas diferentes de ver e implantar a valorização dos professores da educação básica. Na proposta alternativa 01 - Sugestões para ampliação e continuidade da política de valorização dos profissionais da educação básica faz uma análise das sugestões dos gestores educacionas federais e municipais e dirigentes de entidades nacional e sindicais municipais. E a proposta altenativa 02 - balanço crítico para alteração do eixo da política de valorização dos profissionais da educação básica apresenta algumas ideias para se repensar e redirecionar o sentido da política de valorização dos professores da educação básica. 
3.1 Avanços: outros elementos e formas de valorização sugeridas pelos gestores federais e municipais, dirigentes de entidade nacional e sindicais municipais

Neste primeiro item, faz-se uma análise dos elementos de valorização sugeridos pelo Bloco A - gestores educacionais federais; Bloco B - gestores educacionais municipais; e Bloco $\mathrm{C}$ - dirigentes de entidade nacional e sindicais municipais de professores. Apresenta as propostas com o intuito de agregar outros elementos ao PSPN, considerado o elemento principal da política de valorização dos professores da educação básica.

\subsubsection{Bloco A: Gestores educacionais federais}

Neste eixo faz-se uma análise das sugestões/propostas dos gestores educacionais federais para ampliar a valorização dos professores da educação básica dentro da ordem capitalista vigente no país e, desse modo, minimizam a potencialidade do trabalho docente nas escolas. Foi solicitado aos gestores educacionais federais sugestões de outros elementos constituintes da política de valorização dos professores da educação básica. Em resposta, assim se manifestaram:

Além do salário, a melhor maneira de valorizar o profissional é implantar programas que lhe assegure acesso aos bens culturais e tecnológicos [...] levando em conta que faz parte dos custos de manutenção desse professor ir ao teatro, ao cinema, ler livros, ter acesso à melhor banda larga do mundo, aos bens tecnológicos de ponta. O professor tem que ter acesso a tudo isso. E isso custa caro. [...] mas faz parte do seu trabalho [...] e ele não vai tirar só do seu bolso. O poder público tem que entender que investir nisso para o professor é investir no aluno. [...] o professor precisa ter acesso às melhores coisas que estiverem acontecendo no mundo [...] ter uma vida boa e tranquila, morar numa casa decente e estar de bem com a vida para poder entrar feliz numa sala de aula. Então, qualquer coisa que caminhe nesse sentido eu acho que será bem vinda. (Gesro fedral 1).

[...] não tem carreira nem piso, se não tiver gestão democrática [...]. Os espaços democráticos são fundamentais para valorização dos profissionais de educação. Além disso, as condições adequadas de trabalho [...] não adianta ter a garantia do piso e uma carreira estruturada, se as condições mínimas de trabalho e as formas de gestão na escola são precárias. Daí a importância do vínculo entre carreira, piso, salário, gestão democrática e condições de trabalho na escola. Mas isso é um processo em construção. (Gestor federal 2).

Além do salário e do plano de carreira, o sentimento de pertencimento a um espaço é muito importante, para que o professor possa se manifestar, propor, criar, agregar parte do que é e conhece individualmente a um espaço de 
construção coletiva, ou seja, a sala de aula, a escola. [...] Na medida em que os espaços de participação e integração crescem, também aumentam os compromissos e obrigações dos profissionais com seu ambiente de trabalho, e com seus alunos. Os elementos salarial e gestão democrática são pilares centrais, mas os ambientes e as condições materiais da escola são muito importantes. A gestão democrática em sentido ampliado [...] que extrapola os muros da escola, passando pelo diálogo entre os professores, seus representantes e os gestores. O ambiente democrático gera senso de justiça, equilíbrio, compreensão dos limites orçamentários, transparência nas relações e evita privilégios, apadrinhamento político e outros procedimentos similares. A gestão democrática valoriza o professor como parte de um sistema geral [...] isso propicia a compreensão das demandas das reais condições de atendimento às exigências dos professores e da escola. (Gestor federal 3).

Os gestores educacionais federais são unânimes ao afirmar que, além do piso salarial e dos planos de carreira, a gestão democrática é outro elemento da valorização dos professores para se administrar os processos de trabalho, dinamizar as relações humanas na escola, realizar negociações e estabelecer pactuações. Eles entendem que a gestão democrática propicia o envolvimento, a participação de todos os profissionais da educação no âmbito da escola e fora dela, elevando o sentimento de pertencimento a um espaço. Além disso, aumenta o nível de compromisso pedagógico de todos os sujeitos na escola. Enfim, a gestão democrática é compatível e necessária porque propicia vantagens e benefícios à comunidade escolar e, particularmente, à valorização dos professores. Eles creditam na gestão democrática grande benefício porque abre possibilidades e alternativas de solução para as dificuldades que obstaculizam as ações em favor da valorização dos professores e demais profissionais da educação básica na escola.

Os gestores educacionais federais entendem que a gestão democrática é necessária porque, por meio dela, é possível criar condições sociais e materiais adequados, e acesso dos professores aos bens culturais e tecnológicos, para que possam realizar com eficácia e eficiência o seu trabalho na escola.

Ao apontarem a gestão democrática, dialogada, compartilhada como o caminho mais adequado e eficaz na busca de solução para os problemas pertinentes à instituição do PSPN, os gestores federais não atentam para o fato de que a negociação dialogada pode mudar as relações autoritárias na gestão escolar, sem laterar a ordem econômica reguladora da sociedade. A negociação dialogada, democrática e aberta pode ser uma excelente forma de ocultação ideológica e de manipulação e alienação. As negociações baseadas na gestão democrática podem contribuir para desviar o sentido da instituição do PSPN como ação política dos governos federal, estaduais e municipais que continua 
sendo a de preservar e proteger a força do sistema do capital no país. Assim, ao focarem a gestão democrática como solução para os problemas nas escolas pode ser um artifício para esconder as raízes dos problemas relativos à valorização concreta do trabalho realizado pelos professores nas escolas. Só a gestão democrática não é suficiente! Devese levar em conta que a gestão democrática é importante, mas pode contribuir para fortalecer os interesses dos donos do poder econômico, político e ideológico, embora pareça que seja em favor de todas as pessoas na sociedade.

Este segundo eixo apresenta as concepções dos gestores educacionais federais sobre o que vem a ser um professor valorizado? Em resposta, assim se manifestaram:

Professor é uma pessoa para ser admirada pelos alunos. [...] não é o profissional que chega, dá sua aula e vai embora [...] e só entende do assunto da sua aula, repetindo mecanicamente o mesmo conteúdo que há quinhentos anos atrás vem ensinando. Ao contrário, o professor precisa ser uma pessoa com ampla visão de mundo, da vida, das coisas, um ser sensível, sincero e com bons propósitos, pois está formando futuras gerações, as nossas crianças, os nossos jovens e os adultos, na perspectiva de uma educação permanente, visando a construção de uma identidade nacional e a solidaridedade mundial [...] por isso precisamos de uma escola que reflita as questões da sustentabilidade e da solidariedade. Esse é o professor que queremos independentemente da sua disciplina. [...] não pode ser fera em matemática, mas uma péssima pessoa. Assim, valorizar o professor é considerá-lo como ser humano especial [...] porque vai lidar com os outros seres humanos especiais, no sentido de formá-los como seres humanos. [...] para isso precisa também ser educado continuamente. Assim, professor valorizado é ter um salário potente na entrada da carreira e acabar com essa história de dizer que isso é precarização da carreira. [...] é receber um salário digno para poder optar em ser professor ou por outra profissão. [..] professor valorizado tem a ver com a ideia de que é preciso ter um piso básico como referência nacional e que esse mínimo possa crescer acima da inflação.[..] um crescimento real ano a ano para que se chegue à valorização real do professor (Gestor federal 1).

Valorizar o professor é oferecer-lhe um ambiente de trabalho adequado e favorável ao ingressar na carreira. [...] propiciar-lhe condições de uma gestão compartilhada, para que possa socializar suas experiências; uma carga horária compatível para que tenha condições de preparar suas aulas, fazer as avaliações dos seus alunos; um calendário de eventos para participar de congressos, reuniões, discussões e grupos de estudos. A valorização do professor consiste em oferecer-lhe garantia de progressão profissional na carreira; condições de trabalho e gestão democrática; oportunidade de fazer intercâmbio com outros espaços, pesquisas em outras áreas, permutas com professores de outros estados, conhecer experiências internacionais e estudar em outros países. Isso qualifica e dá condições ao professor para que traga um aporte mais qualificado para sua escola. [...] para que isso aconteça é necessário reorganizar a questão financeira. [...] não é tempo de se falar no vazio. A formação do professor deve acompanhar a evolução da carreira, para que possa ter um bom desempenho. [...] e também propiciar-lhe condições de saúde, respeitando os momentos de adoecimento e recuperação. Professor valorizado é poder trabalhar em tempo integral numa mesma escola, para poder combinar os desafios da gestão democrática e da qualidade da educação com a sua capacidade de trabalho (Gestor federal 2). 
Os elementos piso salarial e gestão democrática são pilares centrais, mas os ambientes e as condições materiais da escola são importantes. Professor valorizado é aquele a quem é oferecido oportunidade de boa formação, com universo cultural mais amplo e valores para serem mediados com os valores dos alunos [...] isso necessita da criação de lastros materiais, temporais para olhar, entender, conversar, acompanhar o desenvolvimento dos alunos, espaços democráticos com lastro social para ser reconhecido pela comunidade escolar, pelos alunos e vice-versa. [...] professor valorizado não é mão única [...] somente recebendo, mas também oferecendo à escola. [...] tendo lastros pode se dedicar somente à uma escola, recebendo um ótimo salário numa boa carreira. [...] professor valorizado é esse conjunto de elementos (Gestor federal 3).

Dois pontos podem ser identificados na concepção de professor valorizado explicitada pelos gestores educacionais federais, sendo a dimensão material ao afirmarem que, além do piso salarial e do plano de carreira, o professor deve ter uma ambiente escolar saudável e adequado, materiais didáticos e tecnológicos modernos à sua disposição, apoio e incentivos financeiros para manter contínua a sua formação e cuidar de sua saúde, enfim, um conjunto de elementos tangíveis necessários ao desempenho eficaz e eficiente do professor no trabalho que realiza na escola; e a dimensão humanista, ao afirmarem que o professor é um ser humano especial que trabalha com outros seres humanos especiais, os alunos, visando formá-los como seres humanos para viverem e trabalharem na sociedade. O desenvolvimento integrado dessas duas dimensões constitui a concepção de professor valorizado.

Há outros sentidos que se ocultam nessa concepção de professor valorizado. A dimensão material da valorização do professor é constituída de elementos que podem ser considerados meros arranjos para melhor ajustar o professor ao seu trabalho na escola, visando, sobretudo, a evolução do seu desempenho e os resultados a serem alcançados de modo eficaz e eficiente. O foco na dimensão material contribui para ocultar o valor emancipatório do trabalho do professor e dele como ser humano. Os arranjos materiais podem ser importantes, mas também podem servir como mecanismos de ocultação do verdadeiro valor do professor e do seu trabalho na escola.

A dimensão humanista é mais uma maneira sutil de desviar a atenção da potencialidade do trabalho do professor na escola. O professor é considerado eufemisticamente como um ser especial, sem que seja considerado o ser humano especial que vive e trabalha numa estrutura opressiva que busca aliená-lo no trabalho que realiza na escola. Portanto, dizer simplesmente que o professor é um ser especial expressa um humanismo estéril, que pode contribuir para esconder a raiz da exploração do professor e não apontar o caminho da sua superação. 
A concepção de professor valorizado dos gestores educacionais federais carece de fundamentação filosófico-antropológica, visto que o humanismo idealista que a envolve não leva em conta as implicações sócio-econômicas e políticas estruturais que, concretamente, afetam o trabalho e a vida dos professores.

\title{
3.1.2 Bloco B: Gestores educacionais municipais
}

Foi solicitado aos gestores educacionais municipais sugestões de outros elementos e formas para serem inseridos como avanços na política de valorização dos professores da educação básica. Em resposta, assim se manifestaram:

\begin{abstract}
O reconhecimento público do trabalho do professor é importante. Aqui nós fazemos isso por meio de seminários para apresentação das experiências exitosas dos professores nas escolas. É uma forma de dar mérito ao trabalho do professor. Realizamos grande espetáculo no Iate Clube no dia dos professores. Os professores fizeram o show com violão; realizaram oficinas de dança e música popular brasileira, incluindo performance de tango. As crianças formadas em nossos programas de arte nas escolas prestaram homenagens aos professores. São pequenos detalhes que valorizam muito os professores (Gestor municipal 1).
\end{abstract}

É importante que o professor receba incentivos e apoio no plano de carreira com relação aos aspectos saúde, transporte, alimentação, atividades em área de risco e de pesquisa. (Gestor municipal 2)

A escola precisa ter acesso à internet. O professor precisa ter incentivo e apoio para comprar seu computador e poder realizar cursos de formação a distância. O professor necessita de um plano de saúde, uma rentabilidade melhor e incentivo para fazer cursos. Professor com mais de vinte anos de trabalho tem $50 \%$ da coordenação em casa e vai somente duas tardes à escola. É preciso também diminuir o número de alunos em sala de aula. A parte financeira é a principal. Além disso, o professor necessita de incentivos para a sua formação, um bom plano de saúde, vale transporte, vale alimentação, auxílio moradia, melhores condições de trabalho nas escolas e menor número de alunos em sala de aula. Enfim, necessita de formação específica para trabalhar com deficientes (Gestor municipal 3).

Os gestores educacionais municipais apontam, além do PSPN e o planos de carreira, diversos elementos considerados necessários ao desempenho dos professores no trabalho que realizam na escola, os quais vão desde incentivos à formação, compra de plano de saúde, aquisição de vale transporte, vale alimentação, auxílio moradia, diminuição do número de alunos em sala de aula, até o reconhecimento público por meio de seminários para apresentação das experiências exitosas e recebimento de mérito pelo trabalho realizado. Entendem que com a agregação desses elementos ao 
PSPN, os professores passam a ser mais valorizados porque lhes são oferecidas condições ampliadas para trabalhar e um certo reconhecimento por parte dos gestores municipais.

Existe uma ilusão nas sugestões dos gestores educacionais municipais, por entenderem que somente inserindo mais elementos na politica de valorização dos professores da educação básica os docentes passam a ser mais valorizados. Deixam de perceber que o aumento de elementos pode contribuir e ajudar na valorização imediata dos professores, mas isto não altera a estrutura da política de valorização dos professores que, de fato, simplifica a potencialidade do trabalho que realizam nas escolas. A inserção de mais elementos e formas valorizam parcialmente os professores.

Neste segundo eixo analisa-se as concepções dos gestores educacionais municipais sobre o que vem a ser um professor valorizado? Em resposta, assim se manifestaram:

Considero um professor valorizado, além do piso salarial, aquele profissional reconhecido pelo trabalho que faz na sociedade; dispõe de espaços para desenvolver seu trabalho; recebe incentivos financeiros para transporte, saúde, alimentação, lazer, esporte, cultura, participação garantida em eventos nacionais e internacionais, a fim de divulgar os seus trabalhos e interagir com outros profissionais. Enfim, acho que um profissional valorizado é aquele respeitado por aquilo que é e pelo que faz na sociedade. [...] o reconhecimento público do trabalho desse professor é importante (Gestor municipal 1).

Professor valorizado é aquele que tem as condições adequadas (formação, materiais) para exercer bem a sua profissão e se sentir realizado. É também ser reconhecido pelo exercício profissional para manter sua autoestima elevada ou estar de bem consigo mesmo. [...] é o professor que recebe incentivos e apoio no plano de carreira com relação aos aspectos saúde, transporte, alimentação, atividades em área de risco e de pesquisa (Gestor municipal 2).

É claro que conta muito a parte financeira é muito importante, pois o professor tem uma casa e filhos para sustentar. Mas, o professor precisa se sentir feliz no que faz em sala de aula e ser compreendido, acolhido e protegido pelos colegas, gestores, diretor e alunos. Eu acho que o professor precisa disso.O município precisa disso. E mais, precisa de condições materiais para desenvolver o seu trabalho na escola (Gestor municipal 3).

Os gestores educacionais municipais consideram necessário que, além do PSPN e os planos de carreira, outros elementos e formas são importantes tais como espaços e condições de trabalho, incentivos financeiros para transporte, saúde, alimentação, lazer, esporte, cultura, participação garantida em eventos nacionais e internacionais, a fim de divulgar os seus trabalhos e interagir com outros profissionais. E definem como professor valorizado aquele profissional que dispõe de um conjunto de elementos materiais necessários para desempenhar o seu papel com eficácia e eficiência na escola 
e, por conta disso, é reconhecido pela sociedade, mantendo a sua autoestima elevada e o bem estar consigo mesmo. Inegavelemente, els consideram como suficiente para que o professor sinta-se valorizado oferecer-lhe condições materiais para que possa desenvolver o seu trabalho com eficácia e eficiência.

Ao considerarem que os professores necessitam, sobretudo, de condições materiais para terem um bom desempenho no trabalho, os gestores educacionais municipais focam a eficiência e eficácia nos resultados do trabalho dos professores. Eficiência e eficácia são categorias utilizadas especialmente no campo da iniciativa privada para avaliar e medir processsos e resultados do trabalho produzido. É uma categoria própria da ordem capitalista empresarial. Assim, aproximam a valorização dos professores ao modelo de gestão pública neoliberal gerencialista. Conforme De Paula,

[...] gerencialismo é um movimento internacional pela reforma do Estado, que
se iniciou nos anos 1980 e se baseia principalmente nos modelos inglês e
estadunidense. Enfatiza a eficiência administrativa e se baseia no ajuste
estrutural, nas recomendações dos organismos multilaterais internacionais e no
movimento gerencialista. Foca as dimensões econômico-financeira e
institucional-administrativa. Na organização administrativa, separa entre as
atividades exclusivas e não exclusivas do Estado em três níveis
governamentais. Considera a participação no nível do discurso, mas é
centralizador no que se refere ao processo decisório, à organização das
instituições políticas e à construção de canais de participação popular. Enfim,
enfatiza a adaptação das recomendações gerencialista para o setor público
(PAULA, 2005).

No campo da educação pública, especialmente na escola, para ser eficiente no trabalho, os professores e demais profissionais da educação precisam apenas de mais condições materiais. Essa forma de ver a valorização dos professores remonta a política de grencialismo descrita por De Paula (2005), implantada no país a partir do governo neoliberal do Presidente Fernando Henrique Cardoso. Esse modelo de gestão pública pode ser identificado nas argumentações de Luiz Carlos Bresser Pereira, ministro da Administração e Reforma do Estado (MARE), no perído de 1995 a 1998, e um dos principais expoentes do Plano Diretor da Reforma do Estado no governo de Fernando Henrique Cardoso:

Trata-se [...] de colocar em prática as novas ideias gerenciais e oferecer à sociedade um serviço público de melhor qualidade, atrelando a esse serviço um novo critério de êxito: o objetivo é sempre o melhor atendimento ao cidadão-cliente a um custo menor. Para isto, a implantação das agências autônomas, no nível das atividades exclusivas de Estado, e das organizações sociais, no setor público não estatal será tarefa estratégica. (BRESSER PEREIRA, 1997, p. 59). 
Esse ideário neoliberal expresso na afirmação de Pereira (1997) favorece a compreensão das reformas implantadas na educação básica, e da educação brasileira na sua totalidade. Esse ideário expressa a ideologia do padrão da acumulação do capital e evidencia a priorização do pragmático e da eficiência, a valorização do imediato, a valorização de si mesmo e de outro, que caracterizam a reforma da Educação Básica implantada no Brasil na década de 1990. Por isso somente a oferta de mais condições materiais aos professores apenas contribui para promover o desvio da valorização do elemento essencial que é o trabalho docente no sentido de emancipação do ser humano.

\subsubsection{Bloco C: Dirigentes de entidade nacional e sindicais municipais de professores}

Foi solicitado aos dirigentes de entidade nacional e sindicais municipais sugestões de outros elementos e formas que podem ser inseridos como avanços na política de valorização dos professores da educação básica. Em resposta, assim se manifestaram:

Uma carreira que ofereça tranquilidade, condições de trabalho e jornada compatível ao professor e não seja repleta de bônus, gratificações. Além disso, a avaliação é um processo que precisa ser discutido; avaliação que tenha caráter pedagógico e não seja punitiva; que se avalie a escola, o professor, o ensino, enfim, o processo educativo por inteiro. [...] Além disso, a gestão democrática na escola é muito importante tal como as condições materiais, manutenção da contratação de pessoal, imobiliário, segurança, e assim por diante (Dirigent de entidade nacional 1).

Uma forma de valorização seria a Secretaria de Educação investir mais na formação do professor, oferecendo-lhe cursos com recursos próprios e por meio de convênios com o MEC, evitando que os professores busquem titularidade com os seus recursos. Uma coisa que estamos buscando e ainda está conversação aqui no município é a questão da gestão democrática escolar. Além disso, o professor ainda se sente menosprezado por ter um diretor que é indicado pelo governo e que está o tempo todo cobrando. $\mathrm{O}$ professor sente necessidade de poder escolher a pessoa que vai representar a escola, assim seria mais tranquilo. Deve-se investir também no envolvimento sindical dos professores, pois, quanto maior for a adesão, mais força a categoria tem para negociar benefícios com o município. O sindicato é a união de todos em busca de maior valorização (Dirigente sindical municipal1).

A questão financeira é essencial, mas, além disso, é necessário melhorar a qualidade de vida e saúde do professor, por meio de parcerias com médicos, clínicas. E mais, espaço de lazer com balneário; festa dos professores; campanhas Hemope/Sinprosan salvando vidas; premiações; bailes; churrascos e atividades específicas do sindicato como campanha de formação sindical e jurídica, envolvendo a todos os profissionais das escolas. A nossa preocupação 
é que o profissional se sinta bem e valorizado. Além do piso e da carreira, a gestão democrática é fundamental para o avanço das negociações em favor da categoria. [...] outra forma de valorização é a formação do professor por meio do Parfor, pois deu oportunidade aos profissionais que, futuramente, serão contemplados com a Lei Municipal 18.248 - PCCR, que valoriza financeiramente os profissioinais (Dirigente sindical municipal 2).

Os dirigentes de entidade nacional e sindicais municipais de professores consideram o PSPN e os planos de carreira como os elementos básicos da valorização dos professores da educação básica e, ao mesmo tempo, apontam alguns elementos materiais necessários para que os professores realizem o seu trabalho na escola. Tais elementos reconstituem incentivos para a sua formação dos professores, diminuição do número de alunos em sala de aula, instrumentos pedagógicos, avaliação de desempenho, dentre outros.

As sugestões dos dirigentes de entidade nacional e sindicais municipais de professores se alinham à perspectiva dos gestores federais ao ressaltarem como elemento essencial o aumento de condições materiais para os professores desenvolverem o seu trabalho nas escolas, desfocam a questão básica que é o trabalho como categoria fundante da vida dos professores. Somente aumentar quantitativamente os elementos e formas de valorização, de fato, não significa emancipação dos professores e do trabalho que realizam em seus espaços pedagógicos, mas apenas criação de condições tangíveis aos docentes, para que se ajustem ao sistema de controle social nas escolas que, por sua vez, ajusta-se à ordem reguladora do trabalho na ordem do capital. A quantidade de elementos inseridos na política de valorização dos profissionais da educação pode ser considerada relevante, mas não é o suficiente para emancipar os professores como seres humanos, mas pode aliená-los ainda mais.

Neste segundo eixo sobre as concepções dos dirigentes de entidade nacional e sindicais municipais de professor valorizado, perguntou-se aos dirigentes de entidade nacional e sindicais municipais: o que vem a ser um professor valorizado? Em resposta, assim se manifestaram:

É o professor com boa formação, que não vai transmitir somente um conhecimentozinho que aprendeu na escola, mas sabe que o seu papel vai além da sala de aula. [...] é o professor que se dedica não simplesmente a ensinar matemática ou português sem ter conhecimento de outras coisas. $\mathrm{O}$ mundo muda rapidamente e o professor precisa ser capaz de entender as mudanças e enfrentar os desafios, para poder formar os educandos. Além do piso, uma carreira que ofereça tranquilidade, condições de trabalho e jornada compatível ao professor e não seja repleta de bônus, gratificações (Dirigente de entidade nacional 1 ). 
Professor valorizado é aquele que tem condições de trabalho, material adequado para usar com os alunos em sala de aula. [...] e as escolas lhe ofereçam um bom ambiente. [...] na questão salarial, que tenha um ganho real, sem precisar recorrer a empréstimos bancários para sobreviver. Eu acho que o mais importante não é a questão financeira, mas que o professor se sinta bem. [...] que tenha um programa que priorize a sua saúde nos hospitais, pois, aqui, de dez, seis estão comprometidos com problemas psicológicos, cardíacos, varizes e assim por diante. E mais, professor valorizado é o que tem espaços bonitos nos quais se sinta motivado para executar o seu trabalho com eficácia em beneficio de toda a sociedade do município (Dirigente sindical municipal 1).

A questão financeira é essencial, mas a nossa preocupação é que o profissional se sinta bem e valorizado. Por isso, além do piso e da carreira, a gestão democrática é fundamental para que o professor seja valorizado. [...] professor valorizado é aquele que tem bom salário, boa carreira, saúde e muita alegria ao realizar o seu trabalho (Dirigente sindical municipal 2).

Os dirigentes de entidade nacional e sindicais municipais de professores considerarm que, além do PSPN e os planos de carreira, alguns elementos são indispensáveis à valorização dos professores da educação básica. Ressaltam a necessidade de formação geral do professor, jornada de trabalho compatível, condições adequadas de trabalho, saúde e muita alegria ao realizar o seu trabalho. E mais, apontam a necessidade de incentivos financeiros para lazer e saúde e a prática da gestão democrática como forma de valorizar o professor. Assim, o professor valorizado para os dirigentes de entidades nacional e sindicais municipais é aquele profissional que dispõe sobretudo de condições materiais para realizar seu trabalho na escola.

Ao definirem o professor valorizado como o profissional que necessita de condições materiais para trabalhar, os dirigentes de entidade nacional e sindicais municipais minimizam o sentido de valorização do docente, na medida em que despotencializam o elemento principal que é o trabalho do professor como categoria fundamente do ser humano. A inserção de outros elementos e formas valorizam os professores da educação básica, mas a valorização do trabalho do professor e do próprio professor como ser humano continua sendo escamoteada.

Isto posto, o quadro 04 a seguir, sintetiza as sugestões/propostas dos gestores educacionais e dirigentes de entidade nacional e sindicais municipais, para serem agregadas ao PSPN como avanços na política de valorização dos professores de educação básica. 
Quadro 04 - síntese dos elementos que valorizam os professores do magistério da educação básica, na visão dos gestores educacionais federais e municpais, dirigentes de entidade nacional e sindicais municipais de professores

Além do salário, a instituição de programas que assegurem acesso aos bens culturais e tecnológicos, ao teatro, cinema, livros, dentre outros. Isso faz do trabalho do professor, tendo em vista a formação do aluno. Além disso, o professor precisa ter uma vida boa e tranquila, morar numa casa decente, ter autoestima elevada para entrar feliz na sala de aula. (Gestor educacional federal 1)

Além da garantia do piso e do plano de carreira, criação de espaços democráticos, condições adequadas de trabalho, valorizam os profissionais de educação na escola. Mas, isso é um processo em construção. (Gestor educacional federal 2)

O piso salarial é o elemento básico, mas a criação de espaços democráticos e condições materiais da escola são elementos importantes. Na medida em que os espaços de participação e integração crescem, também aumentam os compromissos e obrigações dos profissionais para com seus alunos. $\mathrm{O}$ ambiente democrático gera senso de justiça, equilíbrio, compreensão dos limites orçamentários, compreensão das demandas e condições de atendimento às necessidades da escola. (Gestor educacional federal 3)

Além do salário, plano de carreira e formação, o reconhecimento público do trabalho do professor, por meio de seminários para apresentação das experiências exitosas dos professores, comemoração do dia do professor em clubes (show com violão, oficinas de dança e música popular brasileira, performance de tango) são pequenas ações que dão mérito e valorizam muito os professores. (Gestor educacional municipal 1)

No plano de careira devem ser inseridos incentivos e apoio com relação aos aspectos saúde, transporte, alimentação, atividades em área de risco e de pesquisa. (Gestor educacional municipal 2)

A parte financeira é a principal, mas, além disso, o professor necessita de incentivos para a sua formação, um bom plano de saúde, vale transporte, vale alimentação, auxílio moradia, melhores condições de trabalho nas escolas e menor número de alunos em sala de aula. Necessita de formação específica para trabalhar com alunos deficientes. (Gestor educacional municipal 3).

Uma carreira que ofereça tranquilidade, condições de trabalho e jornada compatível ao professor e que não seja cheia de bônus, gratificações. A avaliação de desempenho é necessária, desde que tenha um caráter pedagógico (a escola, o professor, o ensino, o aluno, os pais, enfim, o processo educativo por inteiro) e não punitivo. A gestão democrática na escola é muito importante tal como as condições materiais, manutenção da contratação de pessoal, imobiliário, segurança, e assim por diante. (Dirigente de entidade nacional 1).

Mais investimento na formação dos professores por parte da Secretaria Municipal de Educação, propiciando-lhes cursos, convênios com o MEC, evitando que os professores paguem a sua formação. A gestão democrática nas escolas é necessária para fortalecer as relações no ambiente escolar. Devese investir mais no envolvimento sindical dos professores, para fortalecer a categoria nas negociações com a Secretaria de Educação Municipal, prefeitura e outros órgãos no município. (Dirigente sindical municipal 1)

Além do piso salarial e o plano de carreira, a gestão democrática é fundamental para o avanço das negociações em favor da categoria de professores. Além disso, é necessário melhorar a qualidade de vida e saúde do professor, por meio de parcerias com médicos, clínicas. E mais, são importantes outros elementos como espaço de lazer com balneário, festa dos professores, campanhas na área de saúde, premiações, bailes, churrascos e atividades específicas do sindicato como campanha de formação sindical e jurídica, envolvendo a todos os profissionais das escolas. (Dirigente sindical municipal 2)

Fonte: Elaborado pelo autor, a partir das entrevistas realizadas no período de 21.11.2012 a 19.02.2013. 
$\mathrm{O}$ quadro 04 mostra que os gestores educacionais e dirigentes de entidade nacional e sindicais municipais têm por objetivo agregar outros elementos ao PSPN, em favor da valorização dos professores do magistério da educação básica. As sugestões/propostas são feitas no sentido de ampliar e fortalecer a política de valorização dos profissionais da educação básica e, assim, valorizar ainda mais os docentes. Ressalta-se que há uma convergência no modo de pensar e agir dos gestores e dirigentes, pois todos entendem que a valorização docente consiste fundamentalmente na sua valorização salarial. Entendem que a lógica para se ampliar a valorização dos professores deve ser quantitavista, por meio da agregação de mais elementos ao PSPN.

O que o quadro 04 não mostra, mas deve ser explicitado? As sugestões/propostas dos gestores e dirigentes pautadas no aumento de elementos materiais para serem inseridos na política de valorização dos professores significa a inserção de arranjos para melhor ajustar o professor ao seu trabalho na escola, visando, sobretudo, a melhoria do seu desempenho e resultados eficientes e eficazes. Com isso, o foco dado ao aspecto quantitativo contribui para ocultar o valor emancipatório do trabalho do professor e dele como ser humano.

\subsection{As perspectivas da Divape/Sase/MEC no encaminhamento de ações e instrumentos para implantação do Piso Salarial Profissional Nacional}

A Divape/Sase/MEC vem desenvolvendo ações e instrumentos para apoiar a instituição do PSPN e os planos de carreira nos entes federados, desde o governo do Presidente Luiz Inácio Lula da Silva até o governo da Presidente Dilma Rousseff, ou seja, no período de 2003 a 2014. Esses governos traçaram e excutaram uma estratégia de desenvolvimento socioeconômico de longo prazo, anunciada na campanha eleitoral de 2002, e reiterada em uma série de documentos e pronunciamentos oficiais: crescimento com baixa inflação e redistribuição de renda, associado ao modelo de consumo de massa (Bielschovisky, 2014, p. 1).

No Programa de Governo 2002, da Coligação Lula Presidente, as linhas do novo modelo estavam assim anunciadas:

[...] O motor básico do sistema e a ampliação do emprego e da renda per capita e, consequentemente, da massa salarial que conformará o assim chamado mercado interno de massas. O crescimento sustentado a médio e a longo prazo resultará da 
ampliação dos investimentos na infraestrurua econômica e social e nos setores capazes de reduzir a vulnerabilidade externa, junto com a políticas de distribuição de renda. (BIELSCHOVISKY, 2014, p. 1).

De fato, percebe-se que o objetivo maior dessa estratégia tem sido a inclusão e a proteção social, com a intenção de reduzir ao máximo a pobreza e promover a igualdade de oportunidades para os cidadãos brasileiros. E sua sustenção econômica em médio e longo prazo reside na continuidade da expansão dos investimentos em produção e consumo de massa, investimento em infraestrutura e na produção de bens e serviços em recurso naturais.

Nesse cenário, deve-se apontar algumas contradições no modelo socioeconômico brasileiro, para sucumbir ao ufanismo que veio sendo cultivado e, ora em 2015, passa por uma crise.

Ao analisar o desenvolvimento brasileiro no início do século XXI, Mattei (2011), aponta três contradições:

a) a atual política econômica, ao mesmo tempo em que consegue manter a estabilidade macroeconômica do país, continua sendo extremamente lenta no enfrentamento da histórica desigualdade social brasileira;

b) o papel dos agentes econômicos vinculados ao boom de commodities primários, ou seja, neste caso, destaca-se que o setor rural exportador é outro grande beneficiado pelo atual modelo primário exportador, uma vez que vem expandindo enormemente sua riqueza, sendo que parte dela está imobilizada em terras, razão pela qual o Brasil continua figurando entre os países com maiores taxas de concentração da propriedade fundiária do mundo. Somando a isso, registra-se que nos útimos anos ocorreu uma enorme evolução do preço das terras em todas as regiões do país;

c) a propalada distribuição de renda não deve ser considerada como universal, uma vez que as bases de dados usadas para calcular essa redução dizem respeito apenas à renda do trabalho, praticamente não existindo no Brasil nenhum indicador relativo à renda do capital, ou seja, não existe um acompanhamento oficial da evolução da renda capitalista no país, apenas mensura-se a renda do trabalho.

Evidencia-se, assim, a partir dessa análise de Mattei (2011), que no passado o nacional-desenvolvimentismo foi implantado com o propósito de promover um modelo de crescimento econômico cujo resultado mais visível foi a geração de exclusão social, o modelo desenvolvimentista em 2011 começou a promover a inclusão social, porém às custas de um uso intensivo dos recuros naturais, ou seja, terras, jazidas minerais, reservas de petróleo, 
florestas nativas, água, dentre outros elementos, o que certamente afeta o presente e afetará muito mais o futuro da nação.

Nessa conjuntura se situam as ações que vêm sendo realizadas pelo governo vigente, por meio da Divape/Sase/MEC, em favor da instituição do PSPN no entes federados, configuradas em três tipos, tendo como fonte de informações os arquivos internos da Divape/Sase: a) Ações internas institucionais; b) Ações nas relações com os entes federados; e c) Ações de assistência técnica.

As ações desenvolvidas e/ou em processo de desenvolvimento pela Divape/Sase/MEC se fundamentam no Decreto $\mathrm{n}^{\mathrm{o}} 7.690$, o qual dispõe sobre suas principais atribuições, assim definidas:

I - auxiliar os Estados, o Distrito Federal e os Municípios:

a) na estruturação de carreiras para os profissionais da educação; e

b) na definição de critérios técnicos de mérito e desempenho para a escolha de diretores de escola, e das formas de participação da comunidade escolar na respectiva escolha;

trizes para a política nacional de formação continuada para funcionários de escola, construída em regime de colaboração com os sistemas de ensino; e

III - coordenar, em regime de colaboração com os sistemas de ensino, o censo dos funcionários de escola da educação básica. (BRASIL, 2012),

As atribuições da Divape/Sase/MEC se articulam com o que determina a Lei 11.738/2008 e a proposta do Plano Nacional de Educação (PNE), especialmente com as metas 17, 18 e 19 e suas respectivas estratégias. Assim, criam-se as condições jurídico-institucionais para a realização de ações em função da instituição do Piso Salarial Profissional Nacional e a estruturação das carreiras do magistério dos entes federados.

Dentre as ações internas institucionais realizadas pela Divape/Sase/MEC, as que se seguem descritas são consideradas relevantes.

Com base em informações resultantes de seminários regionais, a Divape/Sase elaborou um plano de ações estratégicas para o período de quatro anos - 2011 a 2014, tendo sido reavaliadas e redefinidas em 2012, levando-se em conta os ajustes necessários ao objetivo geral da Sase, que é o de contribuir para a construção do Sistema Nacional de Educação (SNE) no país.

Na linha de assistência técnica, a Divape/Sase vem construindo desde o início do ano de 2013, em parceria com a Diretoria de Tecnologia da Informação - DTI do MEC, um sistema informatizado, para orientar os entes federados na gestão dos planos de carreira. É uma ferramenta que deve propiciar ao gestor fazer simulações dos recursos necessários para manutenção do município nos próximos anos, simulações de investimentos necessários para 
alterações em planos já existentes e elaboração de novos planos de carreira. Com isso, a Divape/Sase visa facilitar principalmente as negociações com os sindicatos de professores, agilizando as decisões dos gestores mediante às propostas salariais feitas por eles, levando em conta as reais condições financeiras dos entes federados. Acompanha esse sistema um manual técnico contendo conceitos básicos e orientações sobre os procedimentos de uso. Trata-se do SisPCR - Sistema de Plano de Carreira e Remuneração.

A Divape/Sase também vem elaborando um livro (ainda sem título), que faz parte do conjunto de materiais para assistência técnica aos entes federados. Trata-se de um conjunto de artigos de autores no campo acadêmico, representantes de sindicatos dos profissionais da educação e de gestores educacionais, nos quais são formulados conceitos básicos e exercícios práticos sobre carreira do magistério e gestão das redes de ensino público.

$\mathrm{Na}$ linha de orientação interna, a Divape/Sase tem prestado assistência e apoio aos órgãos federais vinculados ou não ao MEC, por meio de emissão de notas técnicas e pareceres a proposições legislativas, informações para compor processos e dados de seus indicadores, sendo formas mais frequentes: Aspar - emissão de notas técnicas e pareceres à Assessoria Parlamentar (Aspar) do MEC, analisando proposições parlamentares em tramitação no Congresso Nacional, advindas da Consultoria Jurídica (Conjur), Ministério Público (MP), Tribunal de Contas da União (TCU) e Advocacia Geral da União (AGU) - informações para compor autos processuais, manifestações ou notas técnicas; Painel do Simec - o Sistema de Informações do MEC (Simec) - monitoramento e atualização dos principais indicadores educacionais, especialmente os 627 - Meta 17: Relação entre os Salários Médios de NãoProfessores em relação a Professores da Educação Básica; 659 - Meta 18: Percentual de municípios com planos de carreira para os profissionais do magistério implementados; 660 Meta 19: Percentual de municípios com diretores de escolas públicas de educação básica escolhidos por meio de seleção pública e/ou eleição; 1721 - Situação dos municípios em relação à existência de plano de carreira para o magistério e profissionais de serviço e apoio escolar; e 1722 - Situação dos municípios em relação à forma de escolha dos diretores de escolas públicas de educação básica. A coleta dos dados desses indicadores no Simec ocorre automaticamente, uma vez por mês, extraídos do Plano de Ações Articuladas (PAR). Assim, são constantemente atualizados.

Das ações realizadas pela Divape/Sase/MEC nas relações com os entes federados, estas são apontadas como significativas. Desde o início, a Divape/Sase procurou identificar iniciativas de valorização dos profissionais de educação nos entes federados, para estabelecer processos institucionais de comunicação com gestores dos estados, municípios e Distrito 
Federal e de instituições que representam os interesses dos docentes. Tais processos foram estabelecidos por meio da realização de seminários regionais, envolvendo as secretarias estaduais e municipais de educação.

A diversidade de planos de carreiras nos entes federados, a Divape/ Sase deu início à elaboração de parâmetros de carreira para os profissionais da educação básica, dialogando com o Consed, a Undime e a CNTE. Os encontros com o Consed vêm ocorrendo desde o final de 2013, envolvendo setores de Gestão de Pessoas das Secretarias de Educação de todas as regiões do país. Foram realizados quatro encontros nos quais foi feito um alinhamento de pontos como abrangência, cargos e formação inicial para ingresso. As atividades foram retomadas no início de 2015, já com as novas equipes de trabalho das Secretarias de Educação, após as eleições estaduais em 2014.

As reuniões com a Undime tiveram início no segundo semestre de 2014, contando com a participação de gestores e técnicos das secretarias municipais de educação de todas as regiões do pais, membros da equipe técnica da Divape e outros representantes e técnicos da Sase. Nessas reuniões foi feito um balanço inicial da situação dos planos de carreira nos municípios, visando identificar deficiências de gestão, tais como fragilidade da legislação local, excesso de pessoal, desvios de função, pequena capacidade técnica, tímida capacidade de arrecadação, dentre outros. Além dos problemas identificados, o desafio que se impõe à construção de diretrizes nacionais é não ferir a autonomia ou sobrecarregar a capacidade dos entes federados.

O documento final dessas reuniões faz uma apreciação crítica do Projeto de Lei 2.826/2011, focando o diz respeito à relação entre os vencimentos do nível médio com o nível superior de 50\%; dedicação exclusiva; convênio para cessão de pessoal. Além disso, o documento discorda da ideia de elaboração de um modelo único de plano de carreira para todos os profissionais da educação básica. Enfim, recomenda que as diretrizes apresentem elementos que justifiquem a implementação de carreiras; indicação de elementos para carreira dos profissionais do magistério e para os demais profissionais da educação; progressão por tempo de serviço automática e compulsória para todos; evolução por titulação e promoção por merecimento, com avaliação de desempenho não por meio de provas.

Ainda com relação ao Projeto de Lei 2.826/2011, a Undime sugere que a Câmara Federal de Deputados e o Senado Federal sejam consultados sobre a possibilidade de se estabelecer variação salarial para graduação e pós-graduação lato sensu; regras de movimentação de pessoal na rede; remuneração focada no vencimento e não nas 
gratificações; promoção calculada com base no impacto da carreira; e promoção da relação numérica professor/aluno sustentável.

Dentre as ações de assistência técnica realizadas pela Divape/Sase/MEC, estas são consideradas relevantes. A Divape passou a sistematizar, desenvolver e pactuar elementos para construção do SNE, prestando assistência técnica aos entes federados em função da elaboração ou readequação dos planos de carreira; coordenando o processo de comunicação com a Undime, Consed e CNTE para construção de diretrizes e parâmetros de carreira; acompanhando e orientando os entes federados no cumprimento da Lei do Piso; desenvolvendo ações para melhoria das condições de trabalho dos profissionais da educação; estimulando e apoiando os entes federados na elaboração de leis sobre gestão democrática; e colaborando com os entes federados para a realização do Censo dos profissionais da educação.

$\mathrm{Na}$ linha de prestação de assistência técnica aos entes federados para a elaboração ou reelaboração dos planos de careira, a Divape/Sase analisou os já existentes nos estados e DF, nas capitais dos estados e grande quantidade nos municípios de grande, médio e pequeno portes sob os aspectos abrangência, critérios de evolução na carreira (tempo de serviço, mérito e desempenho), avaliação de desempenho, percentual de dispersão entre o vencimento inicial e final e os níveis de formação/habilitação; formação continuada, gratificações e adicionais concedidos. Constatou-se uma diversidade de planos de carreira, por falta de parâmetros nacionais e fundamentação na legislação da educação vigente no país, tais como a Constituição Federal de 1988, a LDB, a Lei 11.738/2008 e nas Resoluções do CNE, dificultando, assim, a realização de uma análise comparativa dos planos existentes.

Ainda nessa linha de assistência técnica, a Divape realizou oficinas de gestão dos planos de carreira, que fazem parte do Plano de Desenvolvimento da Região do Xingu (PDRS Xingu). Foram realizadas três oficinas, sendo a primeira no município de Altamira (PA) em agosto de 2013, a segunda em Belém (PA), em maio de 2014, e a terceira novamente em Altamira, em julho de 2014. Participaram dessas oficinas as Secretarias de Educação de 11 municípios, com o objetivo de avaliar a situação dos planos de carreira e apresentar sugestões para superação dos desafios detectados. Foram constatados diversos problemas que necessitam de um procedimento técnico mais rigoroso.

$\mathrm{Na}$ linha de acompanhamento e orientação para cumprimento do Piso Salarial Profissinal Nacional, a Divape/Sase vem prestando assistência técnica aos entes federados, às entidades sindicais, aos professores e aos cidadãos em geral. Dentre as múltiplas solicitações de orientações encaminhadas à Divape, a mais frequente versa sobre as dificuldades 
financeiras para pagamento do Piso Salarial Profissional Nacional. Para orientar os entes federados, a Divape elaborou um Manual de Legislação básica, contendo as perguntas e respostas mais frequentes.

A Divape vem desenvolvendo, por meio de um acordo entre a Universidade Federal de Minas Gerais (UFMG) e a Sase, uma pesquisa sobre prevenção, condições de trabalho e absenteísmo dos professores na educação básica pública, visando conhecer essa temática e desenvolver ações de prevenção de doenças ocupacionais em conjunto com gestores de educação das redes estaduais e municipais. As ações preparatórias para a coleta de informações se iniciaram no início de 2015.

Com relação à gestão democrática, a Divape/Sase vem estimluando e apoiando os entes federados a elaborarem leis sobre essa questão, tendo já iniciado a elaboração de uma coletânea de textos, por meio de um pacto firmado entre a Sase e a Anpae. Nessa mesma linha de pactuações, a Divape/Sase firmou parceria com o Inep, em 2014, visando colaborar com os entes federados na realização do censo dos profissionais da educação básica.

A Divape/Sase realizou, ainda, o Fórum Nacional de Avaliação do Fundeb, em julho de 2013, conforme previsto no art. 35 da Lei 11.494/2007, contando com participação de representantes da União, dos Estados, do Distrito Federal, dos Municípios, dos trabalhadores da educação e de pais e alunos, com vistas a avaliar o financiamento da educação básica nacional. Avaliou-se estudos sobre o funcionamento dos fundos contábeis estaduais e a complementação da União para o Fundeb; e impactos do Fundeb para a superação das desigualdades regionais. Além disso, definiram-se propostas para o aperfeiçoamento e continuidade do Fundeb, uma metodologia e agenda de avaliação do financiamento da educação brasileira.

Nessa linha de análise avaliativa, a Divape/Sase realizou um estudo dos resultados da assistência financeira do governo federal à promoção da equidade no financiamento da educação básica dos estados e dos municípios no período 2007-2012, considerando a evolução dos recursos do Fundeb; evolução dos valores por aluno do Fundeb; evolução nas matrículas da educação básica, por etapa e modalidade (total e por dependência administrativa); distribuição dos recursos de assistência financeira da União por ente federativo; representatividade da assistência financeira da União no conjunto de recursos estaduais e municipais destinados à educação básica.

A Divape/Sase tem prestado assistência técnica e orientações externas aos municípios, estados e cidadãos sobre a Lei do Piso e a criação ou adequação dos planos de carreira, sendo as formas mais frequentes: Call Center - uma ferramenta denominada Fale Conosco, via 
telefone $\mathrm{n}^{\circ}$ 0800-616161, com média de 1.200 atendimentos por ano; telefone - normalmente a demanda se intensifica no início do ano, quando é divulgado o reajuste do valor do piso salarial; presencial - principalmente aos representantes de entidades e instituições; e-mail <divape@mec.br> - são respondidas centenas de mensagens por ano. Além disso, a Divape tem utilizado o SIC - o Serviço de Informação ao Cidadão, de acordo com a Lei 12.527/2011, que dispõe sobre o direito constitucional de acesso às informações públicas por parte de pessoas físicas ou jurídicas.

Esse painel de ações realizadas e/ou em processo de realização pela Divape/Sase/MEC mostra que a implantação dessas ações significa avanços importantes na construção da política de valorização dos profissionais da educação básica.

Para a Divape/Sase, a estratégia de estabelecer formas de comunicação, pactuações, acordos e parcerias com os entes federados e entidades representativas dos professores da educação básica, principalmente o Consed, a Undime e a CNTE podem ser consideradas como um ponto muito positivo por ter propiciado a criação de parâmetros/diretrizes, ferramentas, subsídios para auxiliar os entes federados a elaborarem seus planos de carreira; e prestação de assistência técnica aos entes federados no cumprimento da Lei do Piso; e desenvolvimento ações para melhorar as condições de trabalhos dos profissionais da educação básica.

No entendimento da Divape/Sase, após a sanção da Lei 11.738/2208, o trabalho que realiza tem contribuído para uma significativa melhoria na valorização dos professores da educação básica. No período de 2010 - 2014, os profissionais do magistério de nível médio tiveram uma melhoria em seus salários, superando o índice de inflação à época, graças a instituição do PSPN, mas a remuneração dos profissionais com formação de nível superior não acompanhou o mesmo crescimento do salário dos profissionais do magistério; diversos entes federados, alegando incapacidade de arcar com os custos da aplicação dos percentuais do piso salarial para todos os profissionais do magistério, achataram as carreiras reduzindo drasticamente a diferença salarial entre os profissionais de nível médio e os profissionais de nível superior; o cumprimento das horas-atividade não vem sendo praticado por todos os entes, ou seja, a maioria dos estados e das capitais não têm levado a termo o que determina a Lei $11.738 / 2008$.

Na visão da Divape/Sase/MEC, a questão da valorização desses profissionais não se esgota no salário e na carreira. Por isso é preciso tratar da superação das condições precárias de trabalho nas escolas, a fim de que se possa avançar na qualidade da educação. Por isso a Divape/Sase considera necessário continuar a execução do Projeto sobre a saúde dos 
professores em cooperação com a Faculdade de Medicina da UFMG, pois a execução desse projeto significa um grande avanço para a valorização dos profissionais da educação.

Enfim, no entendimento da Divape/Sase as ações por ela desenvolvidas não bastam para reverter a desvalorização da profissão docente na educação básica. Mas, com a aprovação do PNE e o cumprimento de suas metas 15, 16 17, 18 e 19 dedicadas à valorização dos profissionais da educação, pode-se alavancar a superação. Por exemplo: criação e da sustentação financeira de carreiras e salários iniciais atrativos; processos de seleção mais adequados de professores; fixação dos professores em uma mesma escola; e condições de trabalho mais adequadas; aperfeiçoamento dos processos de formação para se adequarem à realidade das salas de aula e das escolas.

A Divape/Sase entende que o seu trabalho tem sido muito positivo por contribuir significativamente para a melhoria da política de valorização dos professores da educação básica. Mas, ao mesmo tempo, mesmo que as ações realizadas pela Divape/Sase/MEC pareçam somente positivas, faz parte desta análise buscar o desvelamento do que pode haver de ideológico e alienação escondido nas ações realizadas por essa unidade de gestão do Estado.

Isto posto, pontua-se que a Divape/Sase considera avanços na política de valorização dos professores da educação básica as ações, as estratégias, os procedimentos políticos e técnicos que vem realizando de modo articulado com o entes federados e entidades representantes dos professores da educação básica, principalmente o Consed, a Undime e a CNTE. De fato, do ponto de vista político e técnico, são procedimentos que viabilizam as negociações, os acordos, as pactuações em favor da valorização dos professores da educação básica dentro pacto federativo e nos marcos da ordem capitalista vigente no país. Entretanto, tais procedimentos são práticas democráticas do Estado, realizadas por meio das ações implantadas pela Divape/Sase/MEC no âmbito do governo federal, que não alteram as estruturas, são ações de acomodação.

Nesse contexto, pode-se dizer que as ações da Divape/Sase/MEC são práticas democráticas do Estado que se inserem na ordem capitalista vigente no país e, assim sendo, são utilizadas para valorizar os professores da educação básica, mas em função dos interesses da referida ordem e em detrimento da potencialidade do trabalho dos professores como meio de emancipação humana.

Ao adotar esse procedimento, a Divape/Sase/ não leva em conta o contexto histórico no qual se insere o trabalho que realiza em favor da valorização dos professores da educação 
básica, deixando ausente em suas práticas a referência fundamental que é o domínio da classe dominante e a função do Estado de proteger esse domínio na sociedade brasileira.

Além disso, ressalta-se o fato de que o Estado, por meio de ações neoliberais do gerencialismo valoriza o sistema capitalista, ao mesmo tempo, desvaloriza a potencialidade ontológica do trabalho docente. Oculta o fato de que a valorização dos docentes é indissociável da relação trabalho-educação, que envolve a questão da existência do ser humano, que é o trabalho realizado pelos professores da educação básica.

Em síntese, ao desconectar o contexto histórico das ações políticas e técnicas que vem realizando, a Divape/Sase toma partido em favor de interesses do Estado, embora isto não apareça nos discursos oficiais proclamados em favor da valorização dos professores da educação básica. Daí pode-se concluir que o maior limite das ações políticas e técnicas desenvolvidas pela Divape/Sase/MEC, consideradas como avanços na política de valorização dos professores da educação básica, é a própria ação do Estado na ordem capitalista vigente no país. É na proclamada positividade da ação do Estado que da-se a desvalorização real e concreta dos professores da educação básica.

Esse conjunto de ações desenvolvidas e/ou em processo de desenvolvimento pela Divape/Sase e os outros elementos apresentados pelos gestores educacionais federais e municipais e dirigentes de entidade nacional e sindicais municipais, sugerem a possibilidade duas propostas alternativas para o desenvolvimento da política de valorização dos professores da educação básica: (a) agregar outros elementos ao PSPN nos planos de carreira dos professores do magistério da educação básica, para legitimar a função do Estado e, assim, contribui para o fortalecimento da ordem capitalista vigente no país; e (b) realizar um balanço crítico da política de valorização dos professores do magistério da educação básica vigente, na perspectiva de se adotar como eixo dessa política o trabalho docente enquanto emancipação humana dos professores, em substituição à importância atribuída à valorização salarial dos professores no âmbito da ordem capitalista vigente do país, ou seja, considerar o SPN como meio e não fim da política de valorização dos profissionais da educação básica.

\subsection{Propostas alternativas para a política de valorização dos professores do magistério da educação básica no contexto do segundo mandato da Presidente Dilma Rousseff}

À semelhança dos dois mandatos do Presidente Luiz Inácio Lula da Silva 2003/ 2010, o resgate da dívida social permanece como prioridade no primeiro e segundo mandatos da 
Presidente Dilma Rousseff, mesmo em meio às dificuldades políticas e econômicas nacionais e internacionais. O segundo mandato da Presidente Dilma Rousseff, dentro do realinhamento da gestão democrática do Estado assegurada na CF de 1988, pretende dar prosseguimento à estratégia e a tática "continuidade com mudanças", corrigindo as imperfeições e melhorando e ampliando os mecanismos e instrumentos apropriados ao funcionamento em longo prazo do modelo de crescimento com redistribuição de renda (BIELCHOWISK, 2014).

No campo social, pretende ampliar quantidade e qualidade dos investimentos e gastos sociais, urbanos e rurais, e dar proteção social em geral, aprimorando progressivamente os mecanismos de universalização dessa proteção, buscando evitar a mercantilização dos serviços de natureza social (BIELCHOWISK, 2014).

No campo econômico, visa dar sustenção em longo prazo ao processo de desenvolvimento do país, conservando a estabilidade de preços e intensificando as políticas de investimento, infraestrutura, consumo de massa e proteção aos recursos naturais, bem como a agregação de valor pelas vias do fortalecimento de encadeamentos produtivos internos e de maior incidência de inovação tecnológica nas empresas (BIELCHOWISK, 2014).

Entretanto, a estratégia de dar "continuidade com mudanças" entrou em crise porque o modelo de desenvolvimento preconizado pelo Governo da Presidente Dilma Roussef entrou em crise e, dessa forma, as eleições de 2014 não estão conferindo o desenvolvimento econômico com inclusão social e, o que é mais problemático, com baixo apoio popular.

É nesse contexto de crise do modelo de desenvolvimento econômico, social e político, que assola o segundo mandato da Presiente Dilma Rousseff, afetando as políticas públicas implantadas pelo MEC, que são apresentadas duas propostas alternativas para o desenvolvimento da política de valorização dos professores da educação básica. Pontua-se que a primeira consiste na agregação de outros elementos ao PSPN no plano de carreira, que hoje se constitui no eixo da política de valorização dos professores da educação básica, para contribuir na legitimação dos interesses do governo, da União, do Estado dentro da ordem capitalista vigente no país; e a segunda consiste na realização de um balanço crítico da política de valorização dos professores do magistério da educação básica vigente, visando a possibilidade de se adotar o trabalho docente enquanto emancipação humana dos professores como eixo dessa política, em substituição ao eixo PSPN que os valoriza apenas do ponto de vista econômico e financeiro.

Compreende-se que a política de valorização dos professores da educação básica mesmo sendo conservadora, pode sofrer transformações. A relação da política de valorização dos profissionais da educação básica na ordem capitalista vigente no país é uma relação 
dialética, ou seja, não pode ser considerada apenas como um mecanismo de legitimação da ordem capitalista vigente no país, mas também é um espaço no qual se busca mudanças. Ela é conservadora, mas não é apenas isso. Há uma luta no interior dessa política entre a necessidade de manter a cultura política existente (valores, ideologia), que é tarefa conservadora dessa política e, ao mesmo tempo, a necesidade de criação de uma cultura política diferente, que é sua tarefa transformadora. No momento, pode ser considerada conservadora a política de valorização dos profissionais da educação básica dominante, mas, mesmo assim, o caminho da conservação está em conflito com o caminho da transformação, podendo, então, ocorrer um salto qualitativo nessa política.

Essa política minimiza a valorização dos professores. É uma política de ocultação que faz o jogo da ideologia dominante, cujo objetivo principal é manter para legitimar a ordem capitalista vigente no país. Nesse sentido, ela tem cumprido com êxito o seu papel de ação implantada pelo Estado para cimentar a ideologia da classe dominante no país, mas, por outro lado, também vem constiuindo-a como instrumento que abre possibilidade de avanço em direção à uma política transformadora, real de valorização dos professores da educação básica.

O caminho da transformação explicita as contradições na política de valorização dos profissionais da educação básica e busca desocultá-las para mostrar que apenas inserir mais elementos e formas de valorização na nessa política tem como efeitocontribuir para minimização da valorização dos professores, podendo se transformar num caminho de luta pela valorização real e concreta dos docentes.

Assim, o embate existente na sociedade brasileira se traduz, no momento, em menor proporção, no campo da política de valorização dos professores da educação básica, por uma luta entre uma política de valorização dos professores da educação básica dominante visando sempre inculcar a sua ideologia, que é a ideologia da ordem capitalista vigente no país e, uma outra, a política da transformação e superação, tentando abrir pequenas brechas para lutar contra a política da conservação. O campo da política de valorização dos professores da educação básica configura-se como um espaço em luta, luta entre dois caminhos alternativos diferentes. Por isso valorizar o professor pode significar, fundamentalmente, lutar contra a política dominante, contra a inculcação e a legitimação da ordem capitalista vigente no país, lutar para desocultá-la. Uma política realmente transformadora que faça frente e possa na implantação do PSPN, descobrindo, inventando, propondo razões de esperança e meios de traduzí-lo concretamente. 


\section{Proposta alternativa 01: sugestões para ampliação e continuidade da política de valorização dos professores da educação básica}

Este item apresenta uma proposta de ampliação e aprofundamento da política de valorização dos professores da educação básica, baseada na ideia de política conservadora e legitimadora da estrutura de poder na sociedade brasileira.

A ideia norteadora desta proposta é a de inserir os elementos sugeridos pelos gestores educacionas federais e municipais e dirigentes de entidade nacional e sindicais municipais na política de valorização dos profissionais da educação básica, centrada na instituição PSPN e implementação dos planos de carreira dos professores, para ampliá-la e fortalecê-la como ação política do Estado, articulada e viabilizada pela Sase/MEC.

Levando-se em conta esta ideia, a política de valorização dos professores da educação básica passa a ser ampliada por meio da inserção de elementos que envolvem gestão democrática, incentivos e apoios, manutenção de serviços nas escolas, avaliação de desempenho, reconhecimento público, benefícios e envolvimento dos professores com os sindicatos.

Assim, no que tange à gestão democrática, a construção de espaços democráticos nas escolas e outros ambientes educacionais é um elemento considerado fundamental. Neste sentido, afirmam os gestores federais 1,2 e 3: a implantação da gestão democrática nas escolas, para criar o sentimento de pertencimento a um espaço nos profissionais da educação básica.

Com relação aos incentivos e apoios, programas para assegurar acesso aos bens culturais e tecnológicos (teatro, cinema, livros, internet, dentre outros) são os elementos considerados relevantes. Além disso, aspectos qualidade de vida e saúde, transporte, alimentação, atividades em área de risco, pesquisas precisam ser inseridos nos planos de carreira. Sobre esta questão, os gestores municipais 1, 2 e 3 ressaltam: o poder público precisa entender que investir na formação, saúde, bem estar do professor significa investir no aluno.

No que diz respeito à manutenção de serviços nas escolas, condições físicas e pedagógicas, (contratação e manutenção de pessoal, compra de imobiliário, compra de material didático e pedagógico, manutenção de sistema de segurança, dentre outros); acesso à internet na escola; incentivo e apoio para compra de computadores aos professores e técnicos, para poderem realizar cursos de formação à distância são os elelementos considerados necessários. Sobre esses elementos, o dirigente de entidade nacional 1, gestor federal 2 e 
gestor municipal 3, assim se manifestaram: os professores necessitam de condições materiais para realizar o seu trabalho nas escolas; sem condições materiais os professores não são valorizados.

No que concerne à avaliação de desempenho, a meritocracia ainda é considerada uma forma utilizada, mas, nas palavras do dirigente de entidade nacional 1, a avaliação é um processo que precisa ser discutido, pois precisa ter um caráter pedagógico e não punitivo; que avalie a escola, o professor, o ensino, enfim, o processo educativo por inteiro.

No que tange ao reconhecimento público, participação em encontros nacionais e internacionais para exposição de experiências exitosas em sala de aula é a forma considerada relevante. Nesse sentido, o gestor educacional muncipal 1 afirma: é importante que o trabalho do professor seja reconhecido publicamente por meio de seminários e outros eventos.

Com relação aos benefícios, espaços de lazer com balneário; festa comemorativa ao dia do professor; campanhas de saúde; premiações; churrascos são os elementos considerados necessários. Sobre esses elementos, os dirigentes sindicais municipais 1 e 2 ressaltam: é preciso envolver todos os profissionais das escolas nessas atividades.

Enfim, no que diz respeito ao envolvimento dos professores com os sindicatos, campanha de formação sindical e jurídica é o elemento considerado essencial. Sobre isso os dirigentes sindicais municipais 1 e 2 assim se manifestam: a nossa preocupação é que o profissional se sinta bem e valorizado para fortalecer a categoria nas negociações.

As propostas dos gestores educacionas federais e municipais e dirigentes de entidades nacional e sindicais municipais para serem inseridos na política de valorização dos profissionais da educação básica, formam um conjunto de diversos elementos, envolvendo os aspectos econômico, político, cultural, social, lazer, saúde, formação sindical, dentre outros. Entretanto, esses diversos elementos devem ser agregados ao elemento considerado como unidade básica na política de valorização dos professores da educação básica, que é a instituição do PSPN.

Os elementos sugeridos expressam as intenções, o desejo, a vontade dos gestores e dirigentes de valorizar os professores da educação básica e, ao mesmo tempo, são complementares à valorização dos professores.

Assim, embora não pareçam, as sugestões para ampliar a política de valorização dos professores da educação básica são arranjos para melhor ajustar a política na estrutura e funcionamento da ordem capitalista vigente no país, simplificando a potencialidade do trabalho realizado nas escolas. Dentro da ordem capitalista, são elementos de valorização que podem melhorar imediatamente as relações humanas, as condições de trabalho, a qualidade de 
vida, a formação dos professores nas escolas e, ao mesmo tempo, abrir espaços na luta pela mudança da estrutura da ordem capitalista na qual a educação, as escolas e os professores que trabalham. Portanto pode-se considerar esses elementos e formas de valorização como avanços na política de valorização dos professores da educação básica, dentro da ordem capitalista vigente no país. E, dessa forma, são mecanismos ideológicos para esconder a simplificação do real sentido de valorização dos professores, mas, podem ser vistas também como conquistas dos professores dentro da própria ordem capitalista. $\mathrm{Na}$ realidade, constituem-se em arranjos para melhorar o desempenho dos professores no trabalho que realizam nas escolas, mas mesmo sendo arranjos podem servir para motivar a luta pela valorização do trabalho dos professores e da sua emancipação como seres humanos.

Estas propostas complementares ao PSPN e à carreira e à agestão democrática são indicadores de que algo pode ser feito, mas é preciso caminhar e avançar na direção da valorização do trabalho e da emancipação humana dos professores.

\section{Proposta alternativa 02: balanço crítico para alteração do eixo da política de valorização dos professores do magistério da educação básica}

Apresenta-se nesta proposta alternativa 02 um caminho para se fazer um balanço crítico da política de valorização dos professores da educação básica, com vistas a alterar o eixo da referida política.

Ressalta-se a necessidade de mudança do eixo da política de valorização dos professores da educação básica. Propõe-se que o eixo centrado na instituição do PSPN seja substituído pelo eixo trabalho como emancipação humana dos professores da educação básica. Por onde começar a explicitar a configuração desse eixo?

Em primeiro lugar, pontua-se que falar em trabalho como emancipação humana dos professores da educação básica requer levar em conta o tempo histórico da realidade brasileira como ponto de referência para todas as ações do Estado. Então, como se configura a fisionomia, o rosto do sistema social e político daquilo que se convencionou chamar de realidade brasileira?

A realidade brasileira é marcada historicamente, mesmo em tempos democráticos, por profundas disparidades, diferentes, contradições de toda ordem: políticas - a divisão entre nação e Estado, por exemplo: econômicas, configuradas na abundância e riquezas de uma minoria em detrimento de miséria de milhões de brasileiros; sociais, culturias, regionais, e 
assim por diante. Em verdade, o Brasil é um país de contrastes e a realidade brasileira é um tempo e espaço de contradições.

Nos tempos atuais, estas contradições se evidenciam por uma série de fatos entre a sociedade civil e o Estado. Exemplo disso são as greves e o protestos manifestados, notadamernte, pelo descontentamento diante de uma política social e econômica geradora de misérias. Fundamentalmente, esta é a contradição estrutural do próprio sistema econômico capitalista que gera a divisão da sociedade em classes, não somente diferentes, mas antagônicas, isto é, defendendo interesses opostos: a classe dos trabalhadores, que produzem riquezas sem se beneficiar delas e a classe daqueles que, possuindo os meios, o dinheiro, o capital, fazem multiplicar esse capital pelo trabalho dos outros. A realidade brasileira é marcada por esse ponto: é dividida entre ricos e pobres, entre trabalhadores (a imensa maioria) e a minoria dominante, desfrutando das riquezas.

Em segundo lugar, ressalta-se que não há como falar de trabalho como emancipação humana dos professores da educação básica sem desvelar a função do Estado no tempo histórico da sociedade brasileira. Então, como se configura a função do Estado na sociedade brasileira? Sabe-se que ao longo da história do pensamento político, surgiu uma multiplicidade de concepções a respeito da sociedade civil e do Estado. Deste modo, surgem as funções básicas do Estado, os fundamentos do poder político, as relações entre o político e as demandas dos trabalhadores.

$\mathrm{Na}$ sociedade brasileira, assim como em outras sociedades capitalistas, a relação básica entre as classes sociais é de contradição. Nesse contexto, as funções do Estado são as de promover, garantir e proteger os interesses econômicos, políticos e ideológicos da classe dominante e controlar, disciplinar as reivindicações dos movimentos sociais e sindicais.

Em terceiro lugar, ressalta-se que não há como falar do trabalho como emancipação humana dos professores da educação básica no tempo histórico da sociedade brasileira, sem alicerçá-lo no fundamento ontológico de ser humano.

O trabalho é uma condição material para produção do mundo dos seres humanos. Este subsiste em qualquer forma de sociabilidade. Todavia, no modo de produção capitalista, sua finalidade é a reprodução da mais-valia para atender às necessidades de acumulação e reprodução do capital, em detrimento das necessidades humanas de reprodução social. Isto se chama trabalho alienado. Mas não é esse tipo de trabalho que deve ser o eixo da política de valorização dos professores da educação básica. Ao contrário, o eixo da referida política se não o é, precisa ser o trabalho concreto, destinado a atender as necessidades humanas, que funda o ser social e consiste na vida genérica ativa humana, propiciando a construção de um 
mundo objetivo no qual o ser humano vive e há influência recíproca entre todos os seres humanos. Pois, o que importa, no fim das contas, é a libertação do homem de um gênero de trabalho destrutivo em relação à sua individualidade e que o torna escravo de coisas criadas por ele mesmo. Trata-se de um retorno à atividade não alienada e, portanto, livre, que permita florescer numa sociedade em que a emancipação plena do ser humano seja o objetivo e não a comercialização de mercadorias em primeiro lugar.

O trabalho concreto é, portanto o que permite ao ser humano construir seu mundo objetivo e, a si mesmo, enquanto indivíduo, buscando a satisfação de suas necessidades. Para além da construção de simples meios de sobrevivência, o homem estabelece uma mediação entre si e a natureza, produzindo e reproduzindo sua existência material, vital e espiritual. Nesse sentido, o trabalho de construção de um mundo objetivo, fruto da ação humana sobre a natureza, relaciona-se com a autorrealização do homem, com a sua formação plena. Esse processo não pode, portanto, encontrar seu termo, uma vez que a necessidade é o próprio ser do homem no mundo, constitutiva da sua existência. Entretanto, a práxis humana não é totalmente natural, pois, ao nascer, o homem encontra um mundo que não é suficiente para a satisfação de suas necessidades, de modo que precisa alterá-lo, objetivá-lo e mediá-lo incessantemente.

Nesse contexto, o trabalho docente, diferenciado das demais atividades laborais, mas inserido na totalidade do trabalho nos marcos da ordem capitalista vigente no país, pode-se configurar como trabalho alienado e desumanização dos professores que perdem a característica de seres livres e autoconscientes. Urge a adoção de medidas que os transformem em agentes ativos face ao mundo humanamente criado, tornando-se capazes de tomar as rédeas de suas próprias vidas e ações.

Em quarto lugar, ressalta-se, ainda, que ao falar de trabalho como emancipação humana dos professores e valorização exige-se que gestores e dirigentes empenhados e envolvidos na implantação da política de valorização dos professores da educação básica assumam uma postura política crítica e transformadora mediante as estruturas de poder na sociedade brasileira, definindo com clareza para que, em favor de quem, contra quem e como estão trabalhando? Afinal, trabalhar nessa sociedade significa tomar partido porque não é possível aos envolvidos na política de valorização dos professores assumirem uma posição de pseudo-neutralidade, pois, ou se trabalha em favor dos privilégios das classes dominantes ou contra elas, ou em favor das classes dominadas ou contra elas. Aqueles que se dizem neutros estão apenas servindo aos interesses dos grupos hegemônicos. 
Desta forma, os gestores federais e municipais, e os dirigentes de entidades sindicais envolvidos com a política de valorização dos professores da educação básica, precisam assumir uma postura política em favor da transformação da referida política com o propósito de transformar a educação brasileira e alavancar a mudança das estruturas de poder no país.

Ressalta-se, também, que falar do trabalho como emancipação humana dos professores da educação básica é fundamentar o sentido de emancipação como libertação do ser humano. Nesse sentido, é necessário recorrer à ideia marxiana de emancipação política e humana para alicerçar a política de valorização dos professores da educação básica. Nesse sentido, Gadotti ao analisar o papel do pedagogo na sociedade brasileira, faz este alerta:

\begin{abstract}
A história da educação brasileira é a história da educação do colonizador. A pedagogia do colonizador forma gente submissa, obediente ao autoritarismo do colonizdor. Nessa pedagogia, o educador tem por função policiar a educação para que não se desvie da ideologia do dominador. Numa pedagogia oposta à pedagogia do colonizador (que na falta de melhor expressão chamamos de pedagogia do conflito), o educador assume a sua educação e seu papel eminentemente crítico: à contradição (opressor-oprimido, por exemplo) ele acrescenta a consciência da contradição, forma gente insubmissa, desobediente, capaz de assumir a sua autonomia e participar na construção de uma sociedade mais livre. (GADOTTI, 1985, p. 53).
\end{abstract}

Este alerta serve não somente aos pedagogos, mas também para gestores e dirigentes educacionais envolvidos na construção de uma educação emancipadora no país.

Em quinto lugar, falar do trabalho como emancipação humana dos professores da educação básica é contemplar o sentido de emancipação como libertação do ser humano. Nesse sentido, é necessário recorrer à ideia marxiana de emancipação política e humana para fundamentar a política de valorização dos professores da educação básica.

Na Questão Judaica, Marx centra-se na emancipação política do judeu como uma emancipação incompleta, que resulta de uma cisão do homem na vida pública e na vida privada. Salientando que a emancipação política não implica emancipação humana. E fazendo notar as limitações da emancipação política:

[...] limite da emancipação política manifesta-se imediatamente no fato de que o Estado pode livrar-se de um limite sem que o homem dele se liberte realmente, no fato de que o Estado pode ser um Estado livre sem que o homem seja um homem livre. [...] Os direitos humanos são limitados aos direitos do membro da sociedade burguesa. Numa luta permanente encontram os seus limites nas fronteiras impostas pelos interesses do capital. (MARX, 2009, p. 48)

Não apenas interrogar sobre a natureza dessa política, sua coerência e sua incoerência, suas finalidades, explícitas ou implícitas, a diferença entre o que ela preconiza e o que faz, mas, além disso, pôr em evidência sua função ideológica em relação ao conexto político, 
social e econômico. A leitura crítica dessa política é necessária para todos os sujeitos envolvidos com a implantação da Lei 11.738/2008, tendo em vista o trabalho que realizam em diversos ambientes públicos.

Essa postura implica em definir com clareza para que, como, para quem, contra quem e a favor de quem está sendo implantada essa política de valorização dos professores da educação basica?

A rigor, é de responsabilidade de todos os gestores e dirigentes envolvidos no processo de implementação dessa política assumirem uma postura de criar as condições objetivas para uma nova política emancipadora. Um novo projeto, essa nova alternativa não poderá ser elaborada nos gabinetes dos brurocratas da educação básica. Exige-se escutar os professores juntos, trabalhando coletivamente.

A política de valorização dos professores da educação básica se torna transformadora se tiver papel eminentemente crítico; o papel de inquietar, de incomodar, de perturbar. A função dessa política parece ser a esta: explicitar a contradição que existe envolvendo a arlação opressor-oprimido. Portanto, sua tarefa é a de ativar conflitos para sua superação, tirar o véu que encobre as ideologias, desalienar.

Por isso uma política voltada para a valorização dos professores se faz estimulante e útil na medida em que pode conduzir à uma práxis, como a práxis conduzirá à transformação. Uma política que tem a crítica como eixo de sua filosofia é essencialmente emancipadora, portanto, revolucionária.

Assim, se amanhã uma política de valorização dos professores da educação básica fundada no trabalho e na emancipação humana dos professores for possível é porque, no interior da política conservadora e reacionária, ideológica e alienante emergiram os elementos de uma nova política que se formou na busca da justiça social, dos direitos sociais e das condições dignas de trabalho e vida. 


\section{CONSIDERAÇÕES E RESULTADOS}

Tendo como objeto a instituição do PSPN por meio da Lei 11.738/2008, o estudo buscou analisar o sentido positivo que se atribui a essa ação do Estado para promover a valorização econômica e financeira dos professores do magistério público da educação básica, ao mesmo tempo, verificou como a importância atribuída a esse elemento serve para ocultar a simplificação da potencialidade do trabalho docente como categoria fundante do ser humano dentro da ordem capitalista vigente no país. Daí a questão principal que orientou o estudo: a instituição do Piso Salarial Profissional Nacional, por meio da Lei 11.738/2008, valoriza os profissionais da educação básica?

Em razão dessa questão, a pesquisa analisou elementos e argumentos em favor da inserção da Lei 11.738/2008 na ordem capitalista vigente no país; a visão dos gestores educacionais federais e municipais, e de dirigentes de entidades nacional e sindicais municipais de professores da educação básica sobre a instituição do PSPN; as ações consideradas como avanços pelos gestores educacionais federais e municipais, e dirigentes de entidade nacional e sindicais municipais; e as ações que vêm sendo realizadas pela Divape/Sase/MEC.

$\mathrm{Na}$ análise dessas questões, o estudo recorreu às categorias filosófico-analíticas ideologia e alienação (do método); utilizou a categoria (de campo) valorização do trabalho docente como elemento emancipador dos professores enquanto seres humanos; e a concepção de valorização do trabalho educativo elaborado por Noronha (2012), para develar as contradições que se escondem no sentido positivo que aparece de imediato na instituição do PSPN, dentro da ordem capitalista vigente no país.

Desse modo, o estudo mostrou que: na visão dos gestores educacionais federais $1,2 \mathrm{e}$ 3, a instituição do PSPN valoriza os professores porque consideram o PSPN não apenas como resultado de uma luta corporativa, mas uma necessidade da sociedade brasileira. Entendem que os professores necessitam de um bom salário desde o início da carreira. O PSPN tem que ser atrativo, porque, de imediato, o professor não olha a remuneração final, mas o que lhe interessa é o salário inicial da carreira. Daí a importância da instituição do PSPN para a implementação de um Sistema Nacional de Educação.

$\mathrm{Na}$ visão dos gestores educacionais municipais 1, 2 e 3, a instituição do PSPN era muito desvalorizada, mas, após a decisão do STF, muita coisa mudou na vida dos professores 
e de suas famílias. Outro elemento que também valoriza os professores é a questão de 1/3 da jornada de trabalho, que consideram como resolvida.

$\mathrm{Na}$ visão dos dirigentes de entidade nacional 1 e sindicais municipais 1 e 2 , a instituição do PSPN valoriza os professores porque é a base forte dos planos de carreira, proporcionando melhores condições de vida aos docentes e suas famílias. Entendem que o PSPN potente propicia boas condições de trabalho, moradia decente, condições de saúde, compra de alimentos e assim por diante.

As visões dos nove gestores e dirigentes entrevistados são semelhantes no que tange ao sentido de valorização dos professores do magistério da educação básica. Mesmo ocupando funções e cargos em instituições diferentes, todos consideram o PSPN no plano de carreira como o elemento principal da política de valorização dos professores do magistério da educação básica.

Conhecendo as posições dos gestores e dirigentes sobre o sentido de valorização na instituição do PSPN, considera-se moderna e conservadora a visão que expressam. Moderna porque consideram a inserção da Lei 11.738/2008 comoum avanço na política de valorização dos professores da educacão básica e esta, por sua vez, se insere na gestão democrática do Estado, assegurada na CF de 1988. E conservadora porque considera a instituição do PSPN uma ação positiva do Estado para legtitimar e fortalecer a estrutura da ordem capitalista vigente no país, simplificando a potencialidade do trabalho realizado pelos professores nas escolas.

Nesse sentido, pontua-se que a visão dos gestores e dirigentes sobre a instituição do PSPN é ideológica no sentido de ocultação da realidade, mas, na perspectiva gramsciana, ao mesmo tempo, a consideram como com um avanço da luta dos professores rumo à valorização do trabalho que realizam nas escolas, mesmo dentro da ordem capitalista no país.

Na visão da Divape/Sase/MEC, a instituição do PSPN valoriza os professores da educação básica porque com a assistência técnica que presta aos entes federados, iniciou-se um processo de construção e readequação dos planos de carreira de forma coerente com a instituição do PSPN. Assim a educação deve ser um espaço atraente, especialmente do ponto de vista salarial. Na relação entre os vencimentos inicial e final da carreira não pode haver dispersão longa. O PSPN não deve ser o elemento único de valorização, mas é o elemento essencial. Sem ele torna-se impossível falar em valorização dos profissionais de educação. $\mathrm{O}$ objetivo do PSPN não é apenas responder à uma necessidade reivindicatória do sindicato, mas é uma necessidade do sindicato, dos gestores, do povo brasileiro. O PSPN é um elemento fundamental para o funcionamento de um Sistema Nacional de Educação e vice-versa. 
Sobre as ações da Divape/Sase/MEC, pode-se dizer que são práticas que expressam a gestão democrática do Estado, para valorizar os professores da educação básica. Assim, podese dizer que são realizadas no sentido de legitimar a função do Estado, que visa manter a ordem capitalista vigente no país, mas, ao mesmo tempo, são ações que buscam valorizar o trabalho dos professores como processo de emancipação humana, mesmo dentro da ordem capitalista no país. Assim, por meio das ações de assistência técnica da Divape/Sase/MEC, o Estado democrático minimiza a potencialidade ontológica do trabalho docente, simplificando a relação trabalho-educação, mas abre perspectivas de valorização da existência humana dos professores.

Pode-se dizer, ainda, que para os gestores educacionais federais 1,2 e 3 e municipais 1,2 e 3; e dirigentes de entidade nacional 1 e sindicais municipais 1 e 2; e para Divape/Sase/MEC, a ação politica do Estado valoriza os professores ao instutir o PSPN. Trata-se de uma ação implantada por meio da Lei e, assim sendo, a legalidade deve ser cumprida, mesmo gerando dificuldades e conflitos no contexto real. E mais, o PSPN valoriza a conquista dos professores junto ao Estado no âmbito da sociedade de classes.

Nessa lógica, a instituição do PSPN expressa a inserção de mais um mecanismo legitimador do sistema capitalista, confirmando o fato de que todas as ações políticas, sociais, econômicas, culturais, ambientais, educacionais, jurídicas desveladas ou veladas, explícitas ou ocultas são absorvidas por esse sistema. A instituição do PSPN não foge à essa situação, pois não ocorre à margem ou fora do sistema capitalista no país, mas é uma ação que não pode ser desconsiderada como conquista dos professores.

Dentro da ordem capitalista, a instituição do PSPN deveria valorizar muito mais os professores do ponto de vista econômico e financeiro, mas, na realidade, não é isso que vem ocorrendo, quando se compara o piso salarial dos docentes com o salário de outras categorias profissionais nos entes federados. Por exemplo, segundo a RAIS (2014), no município de Santarém o valor atual (2014) do PSPN é de R $\$ 1.598,17$, portanto, abaixo do salário de um médico da Prefeitura, que é no valor de $\mathrm{R} \$$ 5.351,51. No município de Cidade Ocidental o valor do PSPN é de R \$3.282,82, abaixo do salário de um médico da Prefeitura, que é no valor de $\mathrm{R} \$ 6.801,83$.

$\mathrm{Na}$ perspectiva de valorização do trabalho docente, a valorização dos professores por centrada no PSPN deixa muito a desejar. Considerando a inserção do trabalho educativo na totalidade do trabalho no capitalismo, os professores são levados a enfrentar problemas humanos de diversas tipos: econômico, político, social, cultural, educacional, saúde, emocional, psicológicpa, ético, moral, espiritual, devido às exigências sociais, que 
transformam as políticas educacionais públicas como ferramentas para atender às exigências do capital. Assim, pode-se dizer que a instituição do PSPN valoriza sim uma maior quantidade de dinheiro para consumo dos professores e, assim, incluí-los ainda mais na sociedade de consumo regulada pela ordem capitalista, ou seja, valoriza os professores econômica e financeiramente, mas não os emancipa com seres humanos e nem o trabalho humano que realizam nas escolas.

Dessa forma, os professores sentem ainda sua autonomia reduzida e perdem o controle do produto do trabalho que realizam, resultando num processo contínuo de estranhamento e alienação. Um processo que pode ser chamado de simplificação da autonomia do professor face ao seu trabalho deixando de se autorrealizar no que faz. Um processo de trabalho alienado que se transforma em estresse, sofrimento e frustração. Enfim, o que era para ser uma atividade fundamental à humanização do professor passa a ser realizada apenas com a finalidade de mostrar resultados, produtividade e funcionalidade para atender às exigências e aos interesses do Estado que, por sua vez, visa atender aos interesses do capital.

Por fim, o estudo apontou duas propostas alternativas para a política de valorização dos professores da educação básica. A primeira consiste em inserir os elementos sugeridos pelos gestores educacionas federais e municipais e dirigentes de entidade nacional e sindicais municipais na política de valorização dos profissionais da educação básica, centrada na instituição do PSPN e nos planos de carreira dos professores nos entes federados. Considerase essa proposta continuísta porque se limita em manter a centralidade do PSPN na política de valorização dos professores da educação básica, simplificando a potencialidade do trabalho realizado pelos professores nas escolas.

A segunda proposta consiste na realização de um balanço crítico da atual política de valorização dos professores da educação básica, para uma mudança no eixo dessa política, substituindo o PSPN como o principal elemento da valorização dos professores pela categoria trabalho docente como meio de emancipação humana dos professores da educação básica. Isto implica, necessariamente, em trilhar por um caminho que, de fato, valorize os professores e o trabalho que realizam nas escolas, face à atual conjuntura capitalista neoliberal, na qual os professores continuam sendo transformados em seres oprimidos e banalizados como seres humanos, perdendo a cada dia que passa a potencialidade e dignidade existencial.

Na construção dessa segunda proposta, o estudo sugere a possibilidade de elaboração e utilização de uma categoria que pode ser chamada de "valorização em múltiplas dimensões" dos professores da educação básica, tendo como ponto de partida a concepção de ser humano 
na filosofia da práxis: homem do trabalho. Em linhas gerais, trata-se de tomar como paradigma a referida concepção, levando-se em conta a necessidade de uma reflexão filosófico-antropológica sobre o ser humano em suas diversas dimensões: inventivo e progressivo; capaz de empregar uma linguagem proposicional; pensante; capaz de desenvolver senso ético; capaz de desenvolver uma consciência moral; reflexivo; espiritualista; dotado de emoção estética; social; político; ser de necessidades econômicas; ser finito e inacabado, dentre outras.

Entende-se por ser humano inventivo e progressivo a capacidade de não transmitir seus conhecimento de modo fixo; ser capaz de empregar uma linguagem proposicional, capaz de usar símbolos para articular uma linguagem e escrita e oral; ser pensante: capacidade de pensar de modo universal e abstrato e concreto; ser capaz de desenvolver senso ético: capacidade de discernir o que é certo e errado; ser capaz de desenvolver uma consciência moral: capacidade de saber a cultura do "dever"; ser reflexivo: capacidade de retomar, reconsiderar informações disponíveis, revisar, vasculhar numa constante de significados das coisas; ser espiritualista: capacidade de conectar suas energias vitais com as energias universais; ser dotado de emoção estética: capacidade de compreender e admirar o belo; ser social: capacidade de desenvolver suas potencialidades em sociedade; ser político: capacidade de cooperar para o bem comum de uma sociedade; ser de necessidades econômicas: capacidade de transformar a natureza para sua subsistência e dos seus semelhantes; ser finito e inacabado: capacidade de compreender conscientemente a sua finitude.

Dois pontos devem ser considerados na construção dessa categoria:

a) esforço e rigor interdisciplinar, ou seja, a interface e o diálogo necessários entre os diversos campos de conhecimento que a envolvem;

b) movimento de elaboração a partir da realidade humana concreta dos professores. Isto poderá ser um bom exercício dialético na reestruturação do eixo da política de valorização dos professores da educação básica. 


\section{REFERÊNCIAS}

ABDALLA, Maria de Fátima Barbosa. Trabalhadores da educação: política de prevenção e atendimento à saúde. Cadernos de Educação, Brasília, n. 22, p. 75-92, jan./jun. 2010.

ABICALIL, Carlos Augusto. Piso salarial: constitucional, legítimo, fundamental. Retratos da Escola, Brasília, v. 2, n. 2-3, p. 67-80, jan./dez. 2008.

ABRUCIO, Fernando Luiz. Para além da descentralização: os desafios da coordenação federativa no Brasil. In: FLEURI, Sônia (Org.). Democracia, descentralização e desenvolvimento: Brasil \& Espanha. Rio de Janeiro: FGV, 2006. p. 77-126.

AZEVEDO, Mario Luiz Neves de; OLIVEIRA, Dalila Andrade. O trabalho docente na educação básica no Paraná. Belo Horizonte: Fino Traço, 2012.

BANCO MUNDIAL. Prioridades y estrategias para la educación: examen del Banco Mundial. Washington, D.C.: Banco Mundial, 1996.

BIELSCHOWSKY, Ricardo. O modelo de desenvolvimento proposto por Lula e Dilma. Portal Brasil Debate. Disponível em: <http://brasildebate4.com.br/o-modelo-dedesenvolvimento-proposto-por lula-e-dima/>. Acesso em: 1 jun. 2015.

BRASIL. Câmara dos Deputados. Projeto de Lei no 619, de 2 de abril de 2007. Regulamenta o art. 60, inciso III, alínea "e", do Ato das Disposições Constitucionais Transitórias, para instituir o Piso Salarial Profissional Nacional para os profissionais do magistério público da educação básica. Disponível em:

<http://www.camara.gov.br/proposicoesWeb/fichadetramitacao?idProposicao=346745>. Acesso em: 20 abr. 2013.

BRASIL. Congresso Nacional. Projeto de Lei no 8035, de 2010. Estabelece o Plano Nacional de Educação - PNE para o decênio 2011-2020, e dá outras providências.

BRASIL. Constituição (1988). Constituição da República Federativa do Brasil. Brasília: Senado Federal, Subsecretaria de Edições Técnicas, 2001.

BRASIL. Constituição (1988). Emenda Constitucional no 53, de 19 de dezembro de 2006. Dá nova redação aos arts. $7^{\circ}, 23,30,206,208,211$ e 212 da Constituição Federal e ao art. 60 do Ato das Disposições Constitucionais Transitórias. Brasília. Disponível em:

<http://www.planalto.gov.br/ccivil_03/constituicao/emendas/emc/emc53.htm>. Acesso em: 20 abr. 2013. 
BRASIL. Decreto ${ }^{\circ}$ 7.480, de 16 de maio de 2011. Aprova a Estrutura Regimental e o Quadro Demonstrativo dos Cargos em Comissão do Grupo-Direção e Assessoramento Superiores - DAS e das Funções Gratificadas do Ministério da Educação e dispõe sobre remanejamento de cargos em comissão. Disponível em:

<http://www.planalto.gov.br/ccivil_03/_Ato2011-2014/2011/Decreto/D7480.htm>. Acesso em: 18 nov. 2011.

BRASIL. Decreto no 7.690, de 2 de março de 2012. Aprova a Estrutura Regimental e o Quadro Demonstrativo dos Cargos em Comissão e das Funções Gratificadas do Ministério da Educação. Disponível em: <http://www.planalto.gov.br/ccivil_03/_Ato20112014/2012/Decreto/D7690.htm>. Acesso em: 30 set. 2013.

BRASIL. Lei de 15 de novembro de 1827. Manda criar escolas de primeiras letras em todas as cidades, vilas e lugares mais populosos do Império. Disponível em:

<http://www.planalto.gov.br/ccivil_03/leis/LIM/LIM-15-10-1827.htm>. Acesso em: 11 ago. 2014.

BRASIL. Lei no 9.394, de 20 de dezembro de 1996. Estabelece as diretrizes da educação nacional. Brasília. Disponível em: < http://www.planalto.gov.br/CCIVIL_03/leis/L9394.htm>. Acesso em: 10 ago. 2014.

BRASIL. Lei no 9.424, de 24 de dezembro de 1996. Dispõe sobre o Fundo de Manutenção e Desenvolvimento do Ensino Fundamental e de Valorização do Magistério, na forma prevista no art. $60, \S 7^{\circ}$, do Ato das Disposições Constitucionais Transitórias, e dá outras providências. Brasília. Disponível em: <http://www.planalto.gov.br/ccivil_03/LEIS/L9424compilado.htm>. Acesso em: 10 set. 2013.

BRASIL. Lei no 10.172, de 09 de janeiro de 2001. Aprova o Plano Nacional de Educação e dá outras providências. Brasília. Disponível em:

<http://www.planalto.gov.br/ccivil_03/leis/leis_2001/110172.htm>. Acesso em: 08 ago. 2014.

BRASIL. Lei no 11.494, de 20 de junho de 2007. Regulamenta o Fundo de Manutenção e Desenvolvimento da Educação Básica e de Valorização dos Profissionais da Educação FUNDEB, de que trata o art. 60 do Ato das Disposições Constitucionais Transitórias; altera a Lei no 10.195, de 14 de fevereiro de 2001; revoga dispositivos das Leis nos 9.424, de 24 de dezembro de 1996, 10.880, de 9 de junho de 2004, e 10.845, de 5 de março de 2004; e dá outras providências. Brasília. Disponível em:

<http://www.planaltogov.br/ccivil_03/Leis/L11494.htm>. Acesso em: 20 mar. 2012.

BRASIL. Lei no 11.738 , de 16 de julho de 2008. Regulamenta a alínea "e" do inciso III do caupt do art. 60 do Ato das Disposições Constitucionais Transitórias, para instituir o piso salarial profissional nacional para os profissionais do magistério público da educação básica. 
Brasília. Disponível em: < http://www.planalto.gov.br/ccivil_03/_ato2007-

2010/2008/lei/111738.htm>. Acesso em: 3 jun. 2013.

BRASIL. Lei no 13.005, de 25 de junho de 2014. Aprova do Plano Nacional de Educação PNE e dá outras providências. Brasília. Disponível em: <

http://www.planalto.gov.br/ccivil_03/_ato2011-2014/2014/lei/113005.htm>. Acesso em: 5 jul. 2015.

BRASIL. Medida Provisória n ${ }^{\circ}$ 339, de 28 de dezembro de 2006. Regulamenta o art. 60 do Ato das Disposições Constitucionais Transitórias, e dá outras providências. Brasília. Disponível em: <http://www.planalto.gov.br/ccivil_03/_ato2004-2006/2006/Mpv/339.htm>. Acesso em: 30 set. 2013.

BRASIL. Ministério da Educação. Conselho Nacional de Educação. Parecer no 9, de 2 de outubro de 2012. Trata da implantação da Lei $n^{\circ} 11.738 / 2008$, que institui o piso salarial profissional nacional para os profissionais do magistério público da Educação Básica.

Relatora Maria Izabel Azevedo Noronha. Brasília, 2012.

BRASIL. Ministério da Educação. Conselho Nacional de Educação. Parecer $n^{\circ} 18$, de 2 de outubro de 2012. Reexame do Parecer CNE/CEB n ${ }^{\circ}$ 9/2012, que trata da implantação da Lei $\mathrm{n}^{\circ} 11.738 / 2008$, que institui o piso salarial profissional nacional para os profissionais do magistério público da Educação Básica. Relatora Maria Izabel Azevedo Noronha. Brasília, 2012.

BRASIL. Ministério da Educação. Conselho Nacional de Educação. Resolução no 4, de 13 de julho de 2010. Define as Diretrizes Curriculares Nacionais Gerais para Educação Básica. Brasília. Disponível em:

$<$ http://portal.mec.gov.br/index.php?option=com_docman\&view=download\&alias=5916rceb004-10\&category_slug=julho-2010-pdf\&Itemid=30192>. Acesso em: 20 mar. 2012.

BRASIL. Ministério da Educação. Conselho Nacional de Educação. Resolução no 5 , de 3 de agosto de 2010. Fixa as Diretrizes Nacionais para os Planos de Carreira e Remuneração dos Funcionários da Educação Básica pública. Brasília. Disponível em:

$<$ http://portal.mec.gov.br/index.php?option=com_docman\&view=download\&alias=6322rceb005-10\&category_slug=agosto-2010-pdf\&Itemid=30192>. Acesso em: 30 set. 2013.

BRASIL. Ministério da Educação. Plano Decenal de Educação para Todos. Brasília: MEC, 1993.

BRASIL. Presidência da República. Câmara da Reforma do Estado. Plano Diretor da Reforma do Aparelho do Estado. Brasília, 1995. 
CAMARGO, Rubens Barbosa de et al. Financiamento da educação e remuneração docente: um começo de conversa em tempos de piso salarial. Revista Brasileira de Política e Administração da Educação, Porto Alegre, v. 25, n. 2, p.341-363, maio/ago. 2009.

CARISSIMI, Aline Chalus Vernick. Perfil Profissional e Condições de Trabalho Docente: um estudo sobre os professores dos anos iniciais da RME de Curitiba. 2011. Dissertação (Mestrado em Educação)-Universidade Federal do Paraná, Curitiba, 2011.

CEDES. Carta de Goiânia, 5 de setembro de 1986. In: Conferência Brasileira de Educação, 4. , 1986, Goiânia. Anais da IV CBE. Tomo 2. São Paulo: Cortez, 1988, p. 1238-1244.

CHAUÍ, Marilena. Convite à Filosofia. 6. ed. São Paulo: Ática, 1997.

CONFERÊNCIA NACIONAL DE EDUCAÇÃO, 2010, Brasília. Documento Final. Brasília: Mais Gráfica Editora, 2010.

CONFERÊNCIA NACIONAL DE EDUCAÇÃO BÁSICA, 2008, Brasília. Documento Final. Brasília: MEC, 2008. Disponível em: < http://portal.mec.gov.br/arquivos/conferencia/documentos/doc_final.pdf $>$. Acesso em: 8 mar. 2013.

DUARTE, Adriana et al (Org). O Trabalho docente na educação básica em Minas Gerais. Belo Horizonte: Fino Traço, 2012.

FERNANDES, Florestan. A Constituição inacabada. São Paulo: Estação Liberdade, 1989.

FERREIRA, Elisa Bertolozzi; OLIVEIRA, Dalila Andrade; VIEIRA, Livia Fraga (Orgs). O Trabalho docente na educação básica no Espírito Santo. Belo Horizonte: Fino Traço, 2012.

FRANÇA, Magna. O financiamento da educação básica: do Fundef ao Fundeb. In: CABRAL NETO, Antônio et al (Org.). Pontos e contrapontos da política educacional: uma leitura contextualizada de iniciativas governamentais. Brasília: Liber Livro Editora, 2007.

FREITAS, Luiz Carlos de. Pátria Educadora. Campinas, 25 de abril de 2005. Disponível em: <http://avaliacaoeducacional.com/2015/04/25/patria-educadora-viii/>. Acesso em: 30 ago. 2015. 
FRIGOTTO, Gaudêncio. Educação e crise do capitalismo real. 5. ed. São Paulo: Cortez, 2003.

FRIGOTTO, Gaudêncio. O enfoque da dialética materialista histórica na pesquisa educacional. In: FAZENDA, Ivani (Org.). Metodologia da pesquisa educacional. 9. ed, São Paulo: Cortez, 2004.

GADOTTI, Moacir. Educação e poder: introdução à pedagogia do conflito. 6. ed. São Paulo: Cortez: Autores Associados, 1985.

GRAMSCI, Antonio. Cadernos do Cárcere. Tradução de Carlos Nelson Coutinho. Rio de Janeiro: Civilização Brasileira, 1999. 6 v.

GRAMSCI, Antonio. Maquiavel, a Política e o Estado Moderno, 2. ed. Rio de Janeiro: Civilização Brasileira, 1976.

HEGEL, Friedrich. Fenomenologia do Espírito. Tradução de Paulo Meneses. 2. ed. Petrópolis: Vozes, 1992.

HELOAINI, Roberto. Assédio Moral: autoridade ou autoritarismo. Cadernos de Educação, Brasília, n. 22, jan. 2010.

HÖFLING, Eloisa de Mattos. Estado e políticas (públicas) sociais. Cadernos Cedes, Campinas, n. 55, p. 30-41, nov. 2001.

HUNGARO, Edson Marcelo. A Questão do método na constituição da teoria social de Marx. In: CUNHA, Célio da; SOUZA, José Vieira de; SILVA, Maria Abádia da (Orgs). O método dialético na pesquisa em educação. Campinas: Autores Associados; Brasília: Faculdade de Educação, Universidade de Brasília, 2014.

IANNI, Octavio. Marx: sociologia. São Paulo: Ática, 1996.

JAPIASSU, Hilton; MARCONDES, Danilo. Dicionário Básico de Filosofia. 3. ed. rev. ampl. Rio de Janeiro: Zahar, 2001.

KOSIK, Karel. Dialética do Concreto. Rio de Janeiro: Paz e Terra, 1986. 
KUENZER Acácia Zeneida; CALDAS, Andrea. Trabalho docente: comprometimento e desistência. In: FIDALGO, Fernando; OLIVEIRA, Maria Auxiliadora Monteiro; FIDALGO, Nara Luciene Rocha (Orgs). A Intensificação do trabalho docente: tecnologias e produtividades. Campinas: Papirus, 2009.

LANDINI, Sônia Regina. Significado e sentido do trabalho docente: as contradições no trabalho e sua relação com o quadro de adoecimento psíquico. In: MONFREDINI, Ivelize (Org). Políticas educacionais, trabalho e profissão docente. São Paulo: Xamã, 2008.

MACHADO, Jarbas de Paula. Piso Salarial Profissional Nacional do magistério: conflitos e limites de sua implementação na rede pública estadual de Goiás. 2010. 220 f. Dissertação (Mestrado em Ciências Humanas)-Universidade Federal de Goiás, Goiânia, 2010.

MANCEBO, Deise. Trabalho docente, políticas educacionais e instituição escolar. In: MONFREDINI, Ivelise (Org). Políticas educacionais, trabalho e profissião docente. São Paulo: Xamã, 2008.

São Paulo: Boitempo, 2008.

MARX, Karl. Manuscritos: economía y filosofía. Madrid: Alianza Editorial, 1985.

MARX, Karl. Manuscritos Economico-filosóficos. São Paulo: Martin Claret, 2002.

MARX, Karl. Para a questão judaica. Tradução de José Batata Moura. São Paulo: Expressão Popular, 2009.

MARX, Karl; ENGELS, Friedrich. O Capital: crítica da economia política. São Paulo: Nova Cultural, 1996. (Os Economistas)

Ideologia Alemã. Tradução de José Carlos Bruni e Marco Amélio Nogueira. São Paulo: Grijalbo, 1977.

Manifesto do Partido Comunista. São Paulo: Martins Fontes, 2004.

MATTEI, Lauro. Gênese e agenda do novo desenvolvimentismo brasileiro. In: ENCONTRO INTERNACIONAL DA ASSOCIAÇÃO KEYNESIANA BRASILEIRA, 4., 2001, Rio de Janeiro. Anais do IV Encontro Internacional da AKB. Rio de Janeiro: AKB, 2011. 
MATTOS, Fernando Augusto Mansor de; JAIME JUNIOR, Frederico G. Ganhos sociais, inflexões na política econômica e restrição externa: novidades e continuidades no Governo Lula. Economia \& Tecnologia, Curitiba, v. especial, n. 7, p. 35-48, 2011. Trimestral.

MATTOS, Ilmar Rohloff de. O tempo saquarema: a formação do Estado Imperial. São Paulo: Hucite, 2004.

MATTOS. Marcelo Bardaró. Reorganizando em meio ao refluxo: ensaios de intervenção sobre a classe trabalhadora no Brasil. Rio de Janeiro: Vício de Leitura, 2009.

MAUÉS, Olgaíses et al. (Org.) O trabalho docente na educação básica: o Pará em questão. Belo Horizonte: Fino Traço, 2012.

MONLEVADE, João Antônio Cabral de. Valorização Salarial dos Professores: o papel do Piso Salarial Profissional Nacional como Instrumento de valorização dos professores da educação básica pública. 2000. Tese (Doutorado em Educação)-Faculdade de Educação, Universidade de Campinas, Campinas, 2000.

NETTO, José Paulo. Capitalismo e barbárie contemporânea. Argumentum, Vitória, ES. v. 4, n. 1, p. 202-222, jan./jun. 2012.

NEVES, Lúcia Maria Wanderley (Org). Nova pedagogia da hegemonia: estratégias do capital para educar o consenso. São Paulo: Xamã, 2005.

OLIVEIRA, Dalila Andrade; VIEIRA, Livia Fraga (Orgs). O trabalho docente na educação básica: a condição docente em sete estados brasileiros. Belo Horizonte: Fino Traço, 2012.

OLIVEIRA, João Ferreira de; OLIVEIRA, Dalila Andrade, VIEIRA, Livia Fraga (Orgs.). O trabalho docente na educação básica em Goiás. Belo Horizonte: Fino Traço, 2012.

PAULA, Ana

Paula Paes de. Administração pública brasileira entre o gerencialismo e a gestão social.

Revista de Administração de Empresas, v. 45, p. 36-49, jan./mar. 2005.

PEREIRA, Luiz Carlos Bresser. Reforma do Estado nos anos 90: lógica e mecanismos de controle. Brasília: Ministério da Administração Federal e Reforma do Estado, 1997. Cadernos MARE, n. 1. 
PERONI, Vera Maria. Política educacional e papel do Estado: no Brasil dos anos de 1990. São Paulo: Xamã, 2003.

PORTAL ANPED. Entrevista com Dermeval Saviani. [S.1.], 2014. Disponível em: $<$ http//www.anped.org.br/News/entrevista-com-dermeval-saviani-pne>. Acesso em: 3 mar. 2015 .

PORTAL CM CONSULTORIA. Entrevista com Paulo Renato Souza. [S.1.], 2003.

Disponível em: <

http://www.cmconsultoria.com.br/novo/iframe/ver_artigo.php?fonte=cm_news\&codigo=2773 >. Acesso em: colocar data de acesso.

PORTAL NOVA ESCOLA. Entrevista com Carlos Jamil Cury. [S.1.], 2010. Disponível em: <http://revistaescola.abril.com.br/politicas-publicas/planejamento-e-

financiamento/entrevista-carlos-roberto-jamil-cury-556235.shtml>. Acesso em: 20 mar. 2012.

POULANTZAS, Nicos. O Estado, o poder, o socialismo. Rio de Janeiro: Graal, 1985.

POULANTZAS, Nicos. Poder político e classes sociais. Porto: Portucalense, 1971.

RIBEIRO, Herval Pina. Trabalho, saúde e cidadania: as LER e os transtornos da voz. Cadernos de Educação, Brasília, n. 22, p. 45-74, jan./jun. 2010.

SAES, Décio. Estado e democracia: ensaios teóricos. Campinas: UNICAMP, Instituto de Filosofia e Ciências Humanas, 1998. (Coleção Trajetória, 1)

SAES, Décio. República do capital: capitalismo e processo político no Brasil. São Paulo: Boitempo, 2001.

SAVIANI, Dermeval. Educação e questão da atualidade. São Paulo: Livros do Tatu e Cortez, 1991.

SAVIANI, Dermeval. A nova lei de educação: trajetória, limites e perspectivas. Campinas: Autores Associados, 1997.

SAVIANI, Dermeval. Pedagogia histórico-crítica: primeiras aproximações. Campinas: Autores Associados, 2005. 
SAVIANI, Dermeval. O trabalho como princípio educativo frente às novas tecnologias. In: FERRETTI, Celso João et al (Org.). Novas tecnologias, trabalho e educação: um debate interdisciplinar. Petrópolis: Vozes, 1994.

SILVA, Maria Abádia da. Do projeto político do Banco Mundial ao projeto político pedagógico da escola pública brasileira. Cad. Cedes, Campinas, v. 23, n. 61, p. 283-301, dez. 2003.

SOARES, Laura Tavares. O Desastre social. Rio de Janeiro: Record, 2003.

TERMO DE COOPERAÇÃO No 1/2011. Celebrado entre o Ministério da Educação e a Fundação Universidade de Brasília, 2011.

TOUSSAINT, Eric. A Bolsa ou a vida: a dívida externa do terceiro mundo: as finanças contra os povos. São Paulo: Perseu Abramo, 2002.

VIEIRA. Evaldo. A Política e as bases do direito educacional. Cad. CEDES. Campinas, n. 55, p. 9-29, nov. 2001.

VIEIRA, Juçara Maria Dutra. Piso Salarial para os Educadores Brasileiros: quem toma partido? 2012. Tese (Doutorado em Educação)-Faculdade de Educação, Universidade de Brasília, 2012. 


\begin{abstract}
ANEXOS
Anexo A - Lei no 11.738, de 16 de julho de 2008

Lei $\mathbf{n}^{\mathbf{0}}$ 11.738/2008, de 16 de Julho de 2008,

Regulamenta a alínea "e" do inciso III do caput do art. 60 do Ato das Disposições Constitucionais Transitórias, para instituir o piso salarial profissional nacional para os profissionais do magistério público da educação básica.
\end{abstract}

O PRESIDENTE DA REPÚBLICA Faço saber que o Congresso Nacional decreta e eu sanciono a seguinte Lei:

Art. $1^{\circ}$ Esta Lei regulamenta o piso salarial profissional nacional para os profissionais do magistério público da educação básica a que se refere a alínea "e" do inciso III do caput do art. 60 do Ato das Disposições Constitucionais Transitórias.

Art. $2^{\circ} \mathrm{O}$ piso salarial profissional nacional para os profissionais do magistério público da educação básica será de $\mathrm{R} \$ 950,00$ (novecentos e cinqüenta reais) mensais, para a formação em nível médio, na modalidade Normal, prevista no art. 62 da Lei n 9.394, de 20 de dezembro de 1996, que estabelece as diretrizes e bases da educação nacional.

$\S 1^{\circ} \mathrm{O}$ piso salarial profissional nacional é o valor abaixo do qual a União, os Estados, o Distrito Federal e os Municípios não poderão fixar o vencimento inicial das Carreiras do magistério público da educação básica, para a jornada de, no máximo, 40 (quarenta) horas semanais.

$\S 2^{\circ}$ Por profissionais do magistério público da educação básica entendem-se aqueles que desempenham as atividades de docência ou as de suporte pedagógico à docência, isto é, direção ou administração, planejamento, inspeção, supervisão, orientação e coordenação educacionais, exercidas no âmbito das unidades escolares de educação básica, em suas diversas etapas e modalidades, com a formação mínima determinada pela legislação federal de diretrizes e bases da educação nacional.

$\S 3^{\circ}$ Os vencimentos iniciais referentes às demais jornadas de trabalho serão, no mínimo, proporcionais ao valor mencionado no caput deste artigo. 
$\S 4^{\circ} \mathrm{Na}$ composição da jornada de trabalho, observar-se-á o limite máximo de $2 / 3$ (dois terços) da carga horária para o desempenho das atividades de interação com os educandos.

$\S 5^{\circ}$ As disposições relativas ao piso salarial de que trata esta Lei serão aplicadas a todas as aposentadorias e pensões dos profissionais do magistério público da educação básica alcançadas pelo art. $7^{\circ}$ da Emenda Constitucional $n^{\circ} 41$, de 19 de dezembro de 2003, e pela Emenda Constitucional $n^{\circ} 47$, de 5 de julho de 2005.

Art. $3^{\circ} \mathrm{O}$ valor de que trata o art. $2^{\circ}$ desta Lei passará a vigorar a partir de $1^{\circ}$ de janeiro de 2008, e sua integralização, como vencimento inicial das Carreiras dos profissionais da educação básica pública, pela União, Estados, Distrito Federal e Municípios será feita de forma progressiva e proporcional, observado o seguinte:

I - (VETADO);

II - a partir de $1^{\circ}$ de janeiro de 2009, acréscimo de 2/3 (dois terços) da diferença entre o valor referido no art. $2^{\circ}$ desta Lei, atualizado na forma do art. $5^{\circ}$ desta Lei, e o vencimento inicial da Carreira vigente;

III - a integralização do valor de que trata o art. $2^{\circ}$ desta Lei, atualizado na forma do art. $5^{\circ}$ desta Lei, dar-se-á a partir de $1^{\circ}$ de janeiro de 2010, com o acréscimo da diferença remanescente.

$\S 1^{\circ} \mathrm{A}$ integralização de que trata o caput deste artigo poderá ser antecipada a qualquer tempo pela União, Estados, Distrito Federal e Municípios.

$\S 2^{\circ}$ Até 31 de dezembro de 2009, admitir-se-á que o piso salarial profissional nacional compreenda vantagens pecuniárias, pagas a qualquer título, nos casos em que a aplicação do disposto neste artigo resulte em valor inferior ao de que trata o art. $2^{\circ}$ desta Lei, sendo resguardadas as vantagens daqueles que percebam valores acima do referido nesta Lei.

Art. $4^{\circ}$ A União deverá complementar, na forma e no limite do disposto no inciso VI do caput do art. 60 do Ato das Disposições Constitucionais Transitórias e em regulamento, a integralização de que trata o art. $3^{\circ}$ desta Lei, nos casos em que o ente federativo, a partir da consideração dos recursos constitucionalmente vinculados à educação, não tenha disponibilidade orçamentária para cumprir o valor fixado.

$\S 1^{\circ} \mathrm{O}$ ente federativo deverá justificar sua necessidade e incapacidade, enviando ao Ministério da Educação solicitação fundamentada, acompanhada de planilha de custos comprovando a necessidade da complementação de que trata o caput deste artigo. 
$\S 2^{\circ}$ A União será responsável por cooperar tecnicamente com o ente federativo que não conseguir assegurar o pagamento do piso, de forma a assessorá-lo no planejamento e aperfeiçoamento da aplicação de seus recursos.

Art. $5^{\circ} \mathrm{O}$ piso salarial profissional nacional do magistério público da educação básica será atualizado, anualmente, no mês de janeiro, a partir do ano de 2009.

Parágrafo único. A atualização de que trata o caput deste artigo será calculada utilizando-se o mesmo percentual de crescimento do valor anual mínimo por aluno referente aos anos iniciais do ensino fundamental urbano, definido nacionalmente, nos termos da Lei $\mathrm{n}^{\mathrm{o}}$ 11.494, de 20 de junho de 2007.

Art. $6^{\circ}$ A União, os Estados, o Distrito Federal e os Municípios deverão elaborar ou adequar seus Planos de Carreira e Remuneração do Magistério até 31 de dezembro de 2009, tendo em vista o cumprimento do piso salarial profissional nacional para os profissionais do magistério público da educação básica, conforme disposto no parágrafo único do art. 206 da Constituição Federal.

Art. $7^{\circ}(\mathrm{VETADO})$

Art. $8^{\circ}$ Esta Lei entra em vigor na data de sua publicação.

Brasília, 16 de julho de 2008; 187o da Independência e 120o da República.

\section{LUIZ INÁCIO LULA DA SILVA}

Tarso Genro

Nelson Machado

Fernando Haddad

Paulo Bernardo Silva

José Múcio Monteiro Filho

José Antonio Dias Toffoli 
Anexo B - Roteiro para entrevista semiestruturada com gestores e dirigentes, no período de 21.11.2012 a 19.02.2013

\begin{tabular}{|c|c|}
\hline Eixos & Questões \\
\hline $\begin{array}{l}\text { Sensibilização/ } \\
\text { Envolvimento/ } \\
\text { Participação }\end{array}$ & $\begin{array}{l}\text { 1. Como vem ocorrendo o seu envolvimento com a questão da instituição } \\
\text { do piso salarial para os professores do magistério da educação básica? } \\
\text { 2. Quais foram os momentos mais significativos e difíceis nesse seu } \\
\text { envolvimento? }\end{array}$ \\
\hline Piso Salarial & $\begin{array}{l}\text { 1. Como vem sendo negociada a implementação do piso salarial após a } \\
\text { sanção da Lei no } 11.738 / 2008 \text { ? Quais as alternativas? } \\
\text { 2. Quais as principais dificuldades encontradas no processo de } \\
\text { implementação do piso salarial? } \\
\text { 3. Como a instituição do piso salarial nos entes federativos valoriza os } \\
\text { professores? }\end{array}$ \\
\hline Plano de Carreira & $\begin{array}{l}\text { 1. Quais elementos estruturantes da carreira dos professores? } \\
\text { 2. Quais ações o governo vem negociando para implantação dos planos de } \\
\text { carreira dos professores? } \\
\text { 3. Quais ações dentro dos planos de carreira valorizam os professores? }\end{array}$ \\
\hline $\begin{array}{l}\text { Valorização/ } \\
\text { Desvalorização }\end{array}$ & $\begin{array}{l}\text { 1. Como os professores são valorizados nos planos de carreira após a } \\
\text { instituição do piso salarial nacional? } \\
\text { 2. Da forma como os planos de carreir estão estruturados valorizam os } \\
\text { professores? } \\
\text { 3. Além do piso salarial, quais outros elementos constituem a valorização } \\
\text { dos professores? }\end{array}$ \\
\hline $\begin{array}{l}\text { Outras formas de } \\
\text { valorização }\end{array}$ & 1. Comente outras formas de valorização dos professores. \\
\hline Reserva Técnica & 1. O que é um professor valorizado? \\
\hline
\end{tabular}




\section{Anexo C - Termo de Consentimento livre e esclarecido}

\section{TERMO DE CONSENTIMENTO LIVRE E ESCLARECIDO}

\section{Caro(a) Gestor(a)}

Estou desenvolvendo uma pesquisa intitulada A Implementação do Piso Salarial Profissional Nacional - PSPN - Lei 11.738/2008 sob a Gestão do Ministério da Educação valoriza os Professores da Educação Básica? sob a orientação da Prof ${ }^{a}$ Dra. Maria Abádia da Silva, na área de Políticas Públicas e Sistemas Educacionais, no curso de mestrado profissional em Educação no Programa de Pós-Graduação em Educação ofertado pela Faculdade de Educação (FE) da Universidade de Brasília (UnB), em convênio com o Ministério da Educação (MEC), por meio do Termo de Cooperação no 1/2011, celebrado em 30.05.2011.

Para dar continuidade à essa pesquisa, solicito a sua participação na entrevista gravada, abaixo autorizada, esclarecendo-lhe que as informações coletadas serão mantidas em total anonimato e utilizadas exclusivamente nesse estudo.

Desde já agradeço a sua colaboração, apoio e empenho.

Atenciosamente,

Raimundo Rainero Xavier - - Matrícula UnB nº 110182260

DECLARAÇÃO

$\mathrm{Eu}$, declaro que fui devidamente informado

(a) sobre os objetivos e justificativas deste estudo de forma clara e detalhada e que concordo em participar da entrevista.

Data: ./......................

Assinatura do participante

Assinatura do pesquisador 